$$
\operatorname{Pontifícia~}_{\text {Universidade }} \text { Católica }_{\text {do Rio daneiro }}
$$

Mara Regina de Almeida Griffo

\title{
PRATICANTES EXPLORATÓRIOS APRENDENDO A VIVER JUNTOS NA ESCOLA
}

\author{
Dissertação de Mestrado
}

Dissertação apresentada como requisito parcial para obtenção do grau de Mestre pelo Programa de Pós-graduação em Estudos da Linguagem do Departamento de Letras da PUC-Rio

Orientadora: Profa. Inés Kayon de Miller

Coorientadora: Profa. Adriana Nogueira Accioly Nóbrega

Rio de Janeiro

Dezembro de 2019 


$$
\text { Pontifícia } \text { Universidade }_{\text {Do Rio de Janeiro }}
$$

Mara Regina de Almeida Griffo

\section{PRATICANTES EXPLORATÓRIOS APRENDENDO A VIVER JUNTOS NA ESCOLA}

Dissertação apresentada como requisito parcial para obtenção do grau de Mestre pelo Programa de Pósgraduação em Estudos da Linguagem da PUC-Rio. Aprovada pela Comissão Examinadora abaixo.

Profa. Inés Kayon de Miller

Orientadora

Departamento de Letras - PUC-Rio

Profa. Adriana Nogueira Accioly Nóbrega

Coorientadora

Departamento de Letras - PUC-Rio

Prof. Renato Pontes Costa

Departamento de Educação - PUC-Rio

Profa. Isabel Cristina Rangel Moraes Bezerra

UERJ

Rio de Janeiro, 17 de dezembro de 2019. 
Todos os direitos reservados. É proibida a reprodução total ou parcial do trabalho sem autorização da universidade, da autora e da orientadora.

\section{Mara Regina de Almeida Griffo}

Graduou-se em Pedagogia. Obteve o título de Especialista em Língua Inglesa pela PUC-Rio. Lecionou em cursos de inglês. Atua como professora em um escola particular no Estado do Rio de Janeiro há 17 anos.

Ficha Catalográfica

Griffo, Mara Regina de Almeida

Praticantes exploratórios aprendendo a viver juntos na escola / Mara Regina de Almeida Griffo ; orientadora: Inés Kayon de Miller ; co-orientadora: Adriana Nogueira Accioly Nóbrega. - 2019. 193 f. : il. color. ; $30 \mathrm{~cm}$

Dissertação (mestrado)-Pontifícia Universidade Católica do Rio de Janeiro, Departamento de Letras, 2019.

Inclui bibliografia

1. Letras - Teses. 2. Prática exploratória. 3. Pesquisa do praticante. 4. Professor de inglês. 5. Alunos. 6. Sistema de avaliatividade. I. Miller, Inés Kayon de. II. Nóbrega, Adriana Nogueira Accioly. III. Pontifícia Universidade Católica do Rio de Janeiro. Departamento de Letras. IV. Título. 


\section{Agradecimentos}

À querida orientadora e professora, Inés Kayon de Miller, por sua dedicação, delicadeza e generosidade ao compartilhar sua sabedoria e ensinamentos.

À querida co-orientadora e professora, Adriana Nogueira Accioly Nóbrega, por sua dedicação, delicadeza e generosidade ao compartilhar sua sabedoria e ensinamentos.

À querida professora Maria Isabel Azevedo Cunha, minha gratidão pelos incentivos e pelo apoio.

Ao Grupo da Prática Exploratória e todos os participantes.

Às praticantes exploratórias Clarissa Ewald, Doreen Purcell, Isolina Lyra e Walewska Braga. Agradeço a oportunidade de aprender com vocês.

À PUC-Rio e seus funcionários, em especial à Chiquinha. Muito obrigada.

Aos professores e professoras do PPGEL.

Aos professores da banca examinadora.

À Judith Hanks por ter participado da defesa.

Aos colegas de turma: Ana Paula Meneses, Beatriz Maciel, Bruna Pavam, Emanuelle Souza, Patrícia Graeff, Renan Piedade, Tarcísio Nicácio, Teresa Carvalho, Thais Borges, Thelma Ribeiro, a lista é longa. Muito obrigada a todos e todas pela ajuda ao longo do Mestrado e pela suas monografias, dissertações e teses. 
O presente trabalho foi realizado com o apoio da Coordenação de Aperfeiçoamento de Pessoal de Nível Superior - Brasil (CAPES) - Código de Financiamento 001.

A todos os autores e as autoras citados ao longo da dissertação. Obrigada aos que estão pelo planeta e aos que não mais estão.

Às diretoras da escola, à coordenadora do Programa Bilíngue e às minhas colegas de trabalho.

Aos meus queridos alunos Giovana, Theo, Tito, Breno, Daniel, Gael e Bruna pelo empenho e dedicação nas aulas e pela participação em várias etapas da pesquisa e às suas famílias pelo apoio e confiança ao permitir que seus filhos e suas filhas participassem da pesquisa. Muito obrigada.

À Thais pelos incentivos quando o cansaço era maior que o entusiasmo.

Ao Fabio.

À minha família: mãe, irmãs, cunhado, sobrinhas e sobrinhos.

À minha Bia. 


\section{Resumo}

Griffo, Mara Regina de Almeida; Miller, Inés Kayon (orientadora); Nóbrega, Adriana Nogueira Accioly (co-orientadora). Praticantes exploratórios aprendendo a viver juntos na escola. Rio de Janeiro, 2019. 193p. Dissertação de Mestrado - Departamento de Letras, Pontifícia Universidade Católica do Rio de Janeiro.

Inserido na área da Linguística Aplicada (MOITA LOPES, 2006, 2013), este estudo tem como objetivos buscar maiores entendimentos acerca do trabalho do professor de inglês nos primeiros anos de escolarização, da escola como lugar de afetos e sobre a participação das crianças na pesquisa. Juntos, professora e alunos, crianças de 10-11 anos, lançam um olhar reflexivo sobre a vida na sala de aula em uma escola da rede particular no Rio de Janeiro. Sendo um trabalho colaborativo, caracteriza-se como uma pesquisa qualitativa, interpretativa e interdisciplinar (DENZIN; LINCOLN, 2006), baseada nos princípios da Prática Exploratória (ALLWRIGHT; HANKS, 2009; MILLER, 2010; MILLER; CUNHA, 2017; HANKS, 2017), uma modalidade da pesquisa do praticante (COCHRAN-SMITH; LYTLE, 2009). O conjunto de dados foi gerado no horário escolar com o consentimento dos sete participantes e de seus responsáveis. As Atividades Pedagógicas com Potencial Exploratório (BARRETO et al., 2019) incluem textos escritos em inglês e desenhos realizados pelos alunos, integrando práticas pedagógicas à pesquisa. Tais atividades foram utilizadas como oportunidades para estimular as conversas individuais gravadas em áudio. Os principais temas emergentes nas conversas exploratórias foram os entendimentos dos alunos sobre o professor de inglês, a escola e a colaboração na pesquisa. A análise discursiva dos dados gerados nas conversas transcritas tem como ponto central a avaliação a partir do aporte do Sistema de Avaliatividade (MARTIN; WHITE, 2005; VIAN JR., 2009; NÓBREGA, 2009), arcabouço teórico inscrito na Linguística Sistêmico-Funcional (HALLIDAY, 1994). A avaliação das escolhas léxico-gramaticais no discurso, com foco no campo do afeto, do julgamento e da apreciação, aponta para a maturidade reflexiva dos alunos ao expressar crenças e emoções acerca do contexto de ensino e aprendizagem de inglês. A análise detalhada do discurso contribui para o enriquecimento da pesquisa do praticante, levando à reflexões e ao reconhecimento da professora e dos alunos como produtores de saberes locais e como sujeitos-agentes da sala de aula.

\section{Palavras-chave}

Prática Exploratória; pesquisa do praticante; professor de inglês; alunos; Sistema de Avaliatividade 


\section{Abstract}

Griffo, Mara Regina de Almeida; Miller, Inés Kayon (Advisor); Nóbrega, Adriana Nogueira Accioly (Co-advisor). Exploratory practitioners learning to live together at school. Rio de Janeiro, 2019. 193p. Dissertação de Mestrado Departamento de Letras, Pontifícia Universidade Católica do Rio de Janeiro.

This dissertation, inserted in the field of Applied Linguistics (MOITA LOPES, 2006, 2013), aims at building understandings about the English teachers' work developed in the early years of schooling, about the school as a place of affection and the learners' participation in the research. The teacher and the learners, children aged 10-11, worked together to reflect on classroom life in a private school in Rio de Janeiro. With an emphasis on collaboration, this study is characterized as qualitative, interpretative and interdisciplinary (DENZIN; LINCOLN, 2006), as well as based on the principles of Exploratory Practice (ALLWRIGHT; HANKS, 2009; MILLER, 2010; MILLER; CUNHA, 2017; HANKS, 2017), a kind of practitioner research (COCHRAN-SMITH; LYTLE, 2009). The data was generated during regular school hours under the formal consent of the seven participants and their legal guardians. The set of data includes Potentially Exploitable Pedagogical Activities (BARRETO et al., 2019) and audio recorded exploratory talks. By integrating pedagogical practices and research, the activities were used as opportunities to stimulate reflections during the conversations. The themes that emerged focused on the learners' understandings about the English teacher, the school, and their participation in the research. The discursive analysis of the transcription of the exploratory talk has as its central point the evaluation based on Appraisal Theory (MARTIN; WHITE, 2005; VIAN JR., 2009; NOBREGA, 2009), a theoretical framework inscribed in Systemic Functional Linguistics (HALLIDAY, 1994). The analysis of the lexical-grammatical choices in the students' discourse, focusing on the sub-systems of affect, judgment and appreciation points towards the participants' reflexive maturity, as they express their beliefs and emotions about the context of teaching and learning English. The detailed discourse analysis contributes to the enrichment of practitioner research, leading to further reflections and the recognition of the teacher and the seven students as producers of local understandings, as subjects-agents.

\section{Keywords} Theory

Exploratory Practice; practitioner research; English teacher; learners; Appraisal 


\section{Sumário}

1. Considerações iniciais 12

2. A Prática Exploratória e as vivências compartilhadas 16

2.1. Aprendendo, ensinando e buscando entendimentos 16

2.2. O Grupo da Prática Exploratória do Rio de Janeiro 20

2.3. Os Princípios da Prática Exploratória $\quad 21$

2.3.1. Sobre a qualidade de vida 23

2.3.2. Sobre as questões instigantes ou puzzles 24

2.3.3. Sobre a busca de entendimentos 25

2.3.4. Sobre a integração 26

2.3.5. Sobre o processo de monitorar - monitoring 28

2.4. Os alunos na pesquisa - agentividade 29

2.5. Dick Allwright e Paulo Freire 31

2.6. A pesquisa do praticante 34

3. Afinidades teórico-metodológicas 38

3.1. Posicionamento metodológico 38

3.1.1. A Linguística Aplicada 39

3.1.2. Um viés etnográfico na construção da pesquisa 43

3.1.3. A ética na pesquisa $\quad 44$

3.2. Uma escola habitada há 50 anos 46

3.2.1. O Programa Bilíngue - 17 anos de história 48

3.2.2. Uma escola apaixonada por livros 53

3.3. Eu: me formando professora 55

3.4. Os alunos participantes $\quad 57$

3.5. Minha motivação inicial 59

3.6. Geração dos dados, transcrição e análise 60

4. Aporte teórico para análise dos dados 63

4.1. (Pre)disposições pessoais e profissionais do professor 63

4.1.1. O conhecimento 63

4.1.2. A cultura profissional $\quad 64$

4.1.3. O tato pedagógico $\quad 65$

4.1.4. O trabalho em equipe 66

4.1.5. O compromisso social $\quad 67$

4.2. Crenças e emoções $\quad 69$

4.3. A Avaliação a partir da abordagem sistêmico-funcional 73

4.3.1. Sistema de Avaliatividade $\quad 76$

4.3.2. Afeto, Julgamento e Apreciação 78

5. O professor no Programa Bilíngue da escola 82 
5.1. A formação pessoal, acadêmica e profissional 82

5.2. As atividades 83

5.3. Primeira Atividade Pedagógica com Potencial Exploratório $\quad 84$

5.3.1. Afinal, quem é um bom professor de inglês? 88

5.4. Segunda Atividade Pedagógica com Potencial Exploratório 91

$\begin{array}{ll}\text { 5.4.1. Entrevistando o professor de inglês } & 97\end{array}$

6. O lugar-escola que habitamos como participantes $\quad 100$

6.1. Que lugar-escola é esse? 100

6.2. O lugar-escola descrito pelos alunos 103

6.3. O quintal da escola 106

6.4. O desenho como forma de expressão 107

6.5. Terceira Atividade Pedagógica com Potencial Exploratório 109

6.6. Reflexões 117

7. Análise das conversas exploratórias $\quad 119$

7.1. Análise dos dados 119

7.2. Nossas conversas sobre o professor de inglês $\quad 120$

7.2.1. Meus entendimentos 141

7.3. Nossas conversas sobre o lugar-escola 143

7.3.1. Meus entendimentos 157

$\begin{array}{ll}\text { 7.4. Nossas conversas sobre a pesquisa } & 157\end{array}$

$\begin{array}{ll}\text { 7.5. Meus entendimentos } & 170\end{array}$

$\begin{array}{ll}\text { 8. Considerações finais } & 172\end{array}$

$\begin{array}{ll}\text { 9. Referências bibliográficas } & 177\end{array}$

$\begin{array}{ll}\text { 10. Anexos } & 188\end{array}$ 


\section{Lista de quadros}

Quadro 1 - Os alunos participantes $\quad 58$

Quadro 2 - Representação do afeto no julgamento e na apreciação $\quad 77$

Quadro 3 - Afeto, Julgamento e Apreciação 80

Quadro 4 - Primeira Atividade Pedagógica com Potencial Exploratório 89

Quadro 5 - Segunda Atividade Pedagógica com Potencial Exploratório 97 


\section{Convenções de transcrição}

\begin{tabular}{|c|c|}
\hline$\ldots$ & pausa não medida \\
\hline . & entonação descendente ou final de elocução \\
\hline$?$ & entonação ascendente \\
\hline , & entonação de continuidade \\
\hline palav- & parada súbita \\
\hline$=$ & elocuções contíguas \\
\hline , & enunciadas sem pausa entre elas \\
\hline grifo & ênfase \\
\hline itálico & palavra em outro idioma (inglês) \\
\hline & ${ }^{\circ}$ palavra ${ }^{\circ}$ palavra em voz baixa \\
\hline & $>$ palavra < fala mais rápida \\
\hline & $<$ palavra $>$ fala mais lenta \\
\hline : ou :: & alongamentos \\
\hline[ & início de sobreposição de fala \\
\hline ] & fim de sobreposição de fala \\
\hline$($ ) & fala não compreendida \\
\hline$(())$ & comentário do analista, descrição de atividade não verba \\
\hline "palavra" & fala relatada, reconstrução de um diálogo \\
\hline$\uparrow$ & subida de entonação \\
\hline$\downarrow$ & descida de entonação \\
\hline
\end{tabular}

Convenções de transcrição sugeridas por BASTOS e BIAR (2015) - convenções baseadas nos estudos de Análise da Conversação (Sacks, Schegloff e Jefferson, 1974), incorporando símbolos sugeridos por Schiffrin (1987) e Tannen (1989). 


\section{Considerações iniciais}

Nesse momento acadêmico que meus alunos e eu vivenciamos juntos, não busco respostas, generalizações ou conclusões, mas sim entendimentos provisórios, bem sei, baseados em minhas observações e descrições da vida na sala de aula. Então, quem somos nós nesse espaço-lugar e tempo situados, que se caracterizam discursivamente nesta dissertação de mestrado?

Minha motivação inicial é pesquisar a vida na sala de aula, as interações e as oportunidades de ensino e aprendizagem na escola onde trabalho, que pertence à rede particular de ensino e está localizada no Estado do Rio de Janeiro. Neste contexto, direciono meu foco para uma atividade extraclasse que foi (co)criada e (co)construída para seguir a proposta pedagógica da instituição e atender à comunidade do entorno como uma possibilidade de extensão de horário, mas principalmente como uma opção de escolarização em inglês nos anos iniciais, da educação infantil ao $5^{\circ}$ ano do ensino fundamental. Neste contexto, proponho os seguintes objetivos:

1) buscar maiores entendimentos acerca do trabalho do professor de inglês nos primeiros anos de escolarização, da escola como lugar de afetos e da participação dos alunos na pesquisa;

2) observar/monitorar a vida e as interações na sala de aula;

3) refletir sobre questões relacionadas ao grupo;

4) integrar pesquisa e práticas pedagógicas de ensino e aprendizagem.

Com esses objetivos em mente, o desenvolvimento desta dissertação foi feito a partir de algumas questões que orientaram meu olhar de professorapesquisadora no contexto de uma turma do Programa Bilíngue. De forma colaborativa, os sete alunos da turma e eu nos envolvemos na busca por entendimentos locais e situados de forma inclusiva e sustentável, tendo em vista a qualidade de vida em nosso ambiente pedagógico.

Por estabelecer uma integração entre a Linguística Aplicada e a Pedagogia, acredito que esta pesquisa pertence às duas áreas e pode ser relevante para professores de inglês que atuam nos primeiros anos de escolarização, para 
professores interessados em pesquisar sua própria prática, assim como para o leitor envolvido com práticas pedagógicas de ensino e aprendizagem de inglês. Acredito que esta dissertação pode contribuir para o trabalho do Grupo da Prática Exploratória da PUC-Rio, pois estamos sempre buscando entender a vida na sala de aula.

Todo trabalho de pesquisa requer escolhas. Assim, ao fazer minhas escolhas, deixo de lado várias opções tão importantes e relevantes quanto as minhas. As escolhas começam pela linha de pesquisa do Programa (PPGEL), onde percorri uma trajetória de 3 anos, um como aluna extraordinária e dois como mestranda da Linha 4 - "Discursos, vida social e práticas profissionais" do referido Programa. Dentro das opções na linha 4, situo a pesquisa no campo interdisciplinar da Linguística Aplicada (MOITA LOPES, 2006, 2013) e proponho um diálogo entre a mesma com a Pedagogia (FREIRE, [1974]1979, [1996] 2018a, ; NÓVOA, 2009) fundamentando o estudo nos princípios da Prática Exploratória (ALLWRIGHT; HANKS, 2009, MILLER; CUNHA, 2019) e da Linguística Sistêmico-Funcional (HALLIDAY, 1994), mais especificamente o Sistema de Avaliatividade (MARTIN; WHITE, 2005; NÓBREGA, 2009; VIAN JR., 2010). Para tal, selecionei autores e textos para me auxiliarem nessa construção, deixando de incluir por falta de tempo, oportunidade ou maturidade acadêmica muitos outros autores e textos. Nesse sentido, aponto para a subjetividade na construção da pesquisa. Tal subjetividade se apresenta na minha capacidade de observar o que está a minha volta, de escrever um texto acadêmico, de gerar e analisar dados, de interpretar, e de expressar minhas ideias e pensamentos. Diante desse universo de escolhas, reconheço minha pesquisa como qualitativa, interpretativa, interdisciplinar, inserida na base ético-filosófica da Prática Exploratória.

A divisão do texto da dissertação em capítulos e seções segue os requisitos do trabalho acadêmico e ajuda o pesquisador a organizar as etapas da pesquisa diferentemente do trabalho na sala de aula, o qual possui outras formas de composição, revelando outros arranjos e formas de organização. Dessa forma, meu trabalho coletivo de pesquisa foi arrumado e registrado em oito capítulos, sendo a introdução o primeiro.

No capítulo 2, discorro sobre a Prática Exploratória (ALLWRIGHT, 2001; MILLER; CUNHA, 2009; ALLWRIGHT; HANKS, 2009; HANKS, 2017), 
entendida como uma maneira de olhar e refletir, de forma inclusiva, ética e sustentável, a vida na sala de aula. A Prática Exploratória possibilita que o professor integre pesquisa e práticas pedagógicas cotidianas na busca por entendimentos de questões locais e situadas no contexto histórico-social-cultural do grupo. Considero a Prática Exploratória a espinha dorsal da dissertação.

No capítulo 3, apresento os pressupostos teóricos e metodológicos da pesquisa no referencial teórico da Linguística Aplicada (MOITA LOPES, 2006, 2013). A dissertação pode ser caracterizada como pesquisa qualitativa, com um viés etnográfico, pois foi construída pela minha observação direta e participante com interação constante com o grupo pesquisado. Apresento a escola, o Programa Bilíngue e os sete alunos participantes e cocriadores desta pesquisa.

No capítulo 4, busco articular a base teórica para análise dos dados. Primeiro, busco refletir acerca do professor como sujeito e como profissional e relacionar ao contexto dos professores do Programa Bilíngue. Segundo, busco articular crenças e emoções (BARCELOS, 2001, 2004, 2013, 2019; ARAGÃO, 2019; MATURANA, 2002) que perpassam a educação no que diz respeito ao ensino e à aprendizagem da língua inglesa nos anos iniciais da escolarização. Terceiro, discorro sobre os pressupostos teóricos do Sistema de Avaliatividade (MARTIN; WHITE, 2005; NÓBREGA 2009; VIAN JR., 2010), inserido no arcabouço teórico da Linguística Sistêmico-Funcional (HALLIDAY, 1994), como base para as avaliações realizadas sobre o discurso dos participantes.

No capítulo 5, apresento duas Atividades Pedagógicas com Potencial Exploratório (BARRETO et al., 2019) realizadas pelos alunos participantes a respeito do professor de inglês no contexto da escola. Na primeira, os alunos completam a seguinte frase $A$ good English teacher..., na segunda, escrevem seis perguntas que usariam para entrevistar um professor candidato a trabalhar no Programa Bilíngue. As atividades integram práticas pedagógicas à pesquisa e as mesmas foram realizadas em inglês.

No capítulo 6, apresento a terceira Atividade Pedagógica com Potencial Exploratório, a qual foi dividida em duas partes. A primeira foi realizada fora da sala de aula, sendo a proposta escolher e desenhar um lugar na escola. A segunda, na sala de aula, foi escrever um texto explicando os motivos da escolha. Atividades fora da sala fazem parte da rotina dos alunos e as duas etapas foram realizadas em inglês. 
No capítulo 7, analiso discursivamente os fragmentos selecionados das conversas gravadas entre os sete alunos participantes e eu em três temas: o professor de inglês (NÓVOA, 2009), o lugar-escola (ORR, 2006a, 2006b) e a participação na pesquisa com o objetivo de organizar minha interpretação e minhas observações acerca da forma como os alunos expressam e manifestam suas ideias e pensamentos. Baseio-me no Sistema de Avaliatividade (MARTIN; WHITE, 2005; NÓBREGA, 2009) para realizar a avaliação do discurso dos alunos no contexto local e situado do Programa Bilíngue. As conversas gravadas e transcritas aconteceram em português em uma sala de aula enquanto a turma permaneceu na sala com a professora volante.

No capítulo final, teço algumas considerações articulando os entendimentos que os alunos participantes e eu alcançamos durante a construção da pesquisa. Já posso adiantar que não há conclusões, mas sim oportunidades de reflexão e de aprendizado. 


\section{2}

\section{A Prática Exploratória e as vivências compartilhadas}

Neste capítulo, tenho como objetivo situar o leitor no que vou chamar de eixo norteador da pesquisa - a Prática Exploratória. A Prática Exploratória não é um método de pesquisa, mas sim uma postura pedagógica, a qual está presente na minha maneira de conduzir as aulas como professora, de pesquisar como mestranda, e em meu posicionamento ético em relação aos participantescolaboradores desta dissertação.

\section{1. Aprendendo, ensinando e buscando entendimentos}

Durante muitos anos atuando como professora de inglês num curso de línguas, fui levada a acreditar que os alunos não podiam falar nem ouvir português na sala de aula; que traduzir qualquer palavra mesmo com a intenção de facilitar a compreensão era proibido; que havia uma sequência de lições a serem seguidas, pois aquela era a fórmula para o aluno desenvolver suas habilidades linguísticas; que o aluno era nivelado e classificado de acordo com aquela sequência prédeterminada e pré-estabelecida; e que eu tinha que seguir o roteiro porque a qualquer momento um coordenador podia entrar na sala para me avaliar. Quando deixei este instituto de idiomas para trabalhar na escola, mais especificamente, para cocriar o Programa Bilíngue, eu tinha a certeza de que aprender e ensinar uma língua envolvia muitos outros aspectos.

Aprendi a ser professora na escola, vivenciando a sala de aula, trocando experiências com colegas e coordenadores, participando de cursos e palestras oferecidos na/pela instituição. Dessa forma, passei a entender que a formação do professor acontece dentro escola (NÓVOA, 2009), em um trabalho coletivo que envolve professores e coordenadores visando à formação em serviço.

Aprendi, também, que para ensinar inglês não precisava dizer 'no portuguese in the classroom'. Como dizer 'no portuguese' para a criança que chega chorando porque os pais viajaram e ela está sentindo saudades? Como dizer 'no portuguese' para criança que está passando pelas dificuldades de receber um irmão recém-nascido em casa? Entendi que não havia como separar o português do inglês como se as línguas não possuíssem nenhuma relação entre si. A ideia de 
primeira língua (L1) e segunda língua (L2) foi se desfazendo para mim. Passei a acreditar que nenhuma criança deve ser impedida de falar ou de se expressar por não possuir ainda vocabulário e estruturas linguísticas para se comunicar em inglês na sala de aula. Ao tentar encontrar maneiras de expressar ideias e pensamentos, a linguagem passou a ser entendida, por mim, como uma construção conjunta nas interações que aconteciam no micro cosmo da sala de aula e em outros espaços da escola, ou seja, nos pátios, nos jardins, na horta, no refeitório, na sombra das árvores, no banho de mangueira, nas brincadeiras. Assim, aprendi que "ensinar não é transferir conhecimentos, mas criar as possibilidades para a sua produção ou a sua construção" (FREIRE, [1996] 2018a, p. 24). Com isso em mente, acredito que o desafio para o professor de inglês nos anos iniciais da escolarização é criar oportunidades de aprendizagem dentro e fora da sala de aula.

Com as crianças, aprendi que, por mais que eu preparasse uma aula, nunca ou quase nunca, conseguia seguir as etapas organizadamente, de forma cronometrada como haviam me ensinado meus professores. Pelos mais diversos motivos - um passarinho que entra pela janela, a criança que espeta o lápis no braço do colega, a luz que acaba - quase tudo saia diferente do que estava registrado no planejamento. Contudo, ao final de cada aula, eu tinha a impressão que tudo havia saído melhor do que o planejado. Rapidamente, compreendi que o planejamento tinha que ser inventado, criado e improvisado a cada aula, a cada momento. Percebi a dinâmica e fluidez das interações da sala de aula e comecei a entender que cada aula era única, (re)inventada, (re)(co)criada e contextualizada.

Comecei a entender que o professor de inglês nos anos iniciais da escolarização é ao mesmo tempo um "detetive", que observa a criança e investiga como ajudá-la a usar a língua; um "arquiteto" que traça e desenha maneiras para que as crianças trabalhem juntas construindo conhecimento; e um "salva vidas" que oferece assistência para que a criança aproveite as oportunidades para usar língua (GARCÍA, 2017). Nessa perspectiva, fui me tornando uma professora "detetive, arquiteta e salva vidas" aprendendo e ensinando ao mesmo tempo, em múltiplas vivências na sala de aula.

Minha experiência na escola contribuiu para modificar minha visão de aula. De acordo com Prabhu (1992, p. 225-230), a aula pode ser entendida como uma unidade do currículo; a implementação de um método; um evento social; uma arena de interações. Entendo as aulas no Programa Bilíngue como eventos 
sociais, nos quais professores e alunos seguem certos rituais e possuem uma rotina. Sem dúvida, a sala de aula é uma arena de interações, de convívio complexo, onde professores e alunos são aprendizes, pois "quem ensina aprende ao ensinar e quem aprende ensina ao aprender" (FREIRE, [1996] 2018a, p. 25).

Dito de outra forma, somos todos aprendizes no cotidiano escolar. A sala de aula é, certamente, um espaço de ensinos e aprendizagens múltiplos, de socialização, de oportunidades diversificadas, de relacionamentos e de formação de vínculos afetivos. Assim, a vida na sala de aula é dinâmica. Além de ser um lugar de "oportunidade de aprendizagem" (cf. opportunity for learning) (ALLWRIGHT, 2000, p. 11), é também um lugar de brincadeiras, afetos, reflexões, discussões, dúvidas, certezas, conversas, silêncios, desentendimentos, entendimentos, de teorias e práticas. Ou melhor, de "práticas exploratórias".

Meu primeiro contato com a Prática Exploratória aconteceu no curso de Especialização de Língua Inglesa da PUC-Rio (MILLER; CUNHA, 2017, p. 63), em 2015, durante as aulas de Maria Isabel Azevedo Cunha (Bebel, coordenadora da Especialização) e Clarissa Xavier Ewald. Foi Bebel que me convidou para participar dos encontros do Grupo da Prática Exploratória do Rio de Janeiro (MILLER; CUNHA, 2009). Foi, também, durante o curso de especialização que li o livro The Developing Language Learner: an introduction to Exploratory Practice, escrito por Dick Allwright e Judith Hanks, assim como muitos outros textos escritos pelos membros da Prática Exploratória tanto no Brasil quanto em outros países. Dessa forma, tive a oportunidade de conhecer mais de perto a Prática Exploratória durante as aulas, as reuniões com o Grupo e as leituras.

Inicialmente, minha primeira pergunta foi 'mas o que é a Prática Exploratória? Um método de pesquisa ou uma postura pedagógica?' Como aluna da Especialização, não consegui responder imediatamente. Não havia uma única resposta - 'é isso!'. Assim, os textos escritos por Dick Allwright, Inés Kayon de Miller, Maria Isabel Azevedo Cunha e pelos demais praticantes exploratórios acrescidos dos encontros com o Grupo da Prática Exploratória me ajudaram a compreender que a Prática Exploratória é uma "proposta pedagógicoinvestigativa, com ênfase em princípios ético-reflexivos" (MILLER, 2017, p. 101). Como proposta teórico-metodológica e ético-filosófica de ensinar, aprender, refletir e pesquisar, todos os participantes estão envolvidos na "busca de entendimentos de questões de interesse do grupo" para "coconstruir múltiplos 
conhecimentos" (ibidem, p. 102-103). Dessa forma, pode-se dizer que a Prática Exploratória tem um viés inclusivo, ético e sustentável.

Foi em meados da década de 1980 e início da década de 1990 que Dick Allwright, professor e pesquisador da universidade de Lancaster, Inglaterra, veio ao Rio de Janeiro a convite de uma instituição de ensino de inglês. Segundo Allwright (2005), o motivo do convite foi o fato de sua pesquisa, naquele tempo, ser considerada uma ponte entre os estudos de aquisição de segunda língua e a pesquisa de sala de aula. Através do contato com os professores durante reuniões e workshops, Allwright começou a olhar para a pesquisa em sala de aula de outra maneira, propondo que a mesma passasse a fazer parte da rotina pedagógica. Nesse grupo de professores estavam Inés Kayon de Miller e Maria Isabel Azevedo Cunha. Assim foi surgindo, então, a Prática Exploratória que conhecemos hoje, como uma maneira de pesquisar em sala de aula, com a participação e tomada de decisões por parte de professores e alunos - os praticantes exploratórios. O termo Prática Exploratória, conforme esclarece Hanks (2017, p. 89), substituiu o termo Ensino Exploratório, após conversas entre Dick Allwright com Ralph Bannel, Maria Isabel A. Cunha e Inés K. Miller, que sugeriram uma abordagem mais abrangente para incluir, além dos professores, alunos e pessoas fora da sala de aula de ensino de línguas.

Allwright (ALLWRIGHT; BAILEY, 1991) propõe o ensino exploratório (cf. Exploratory Teaching) como uma modalidade de pesquisa em sala de aula, na qual professores deveriam tentar entender suas próprias questões. Sua intenção era evitar o que denominou de pesquisa parasítica (cf. parasitic research), aquela, na qual o pesquisador entra na sala de aula, observa, coleta dados, retira-se, escreve sua pesquisa e em nada contribui para o contexto por ele investigado. Nas palavras de Allwright (2005, p. 358), a pesquisa do praticante "deve abordar a questão da agentividade, porque [...] oferece uma nova perspectiva de relacionamento entre aqueles que obtêm entendimentos e aqueles que tentam usálos".

Ao reconhecer a agentividade dos professores e alunos na pesquisa de contexto pedagógico, é possível dizer que Allwright (1991) propôs uma mudança de paradigma na maneira de conduzir pesquisas, valorizando a autonomia do professor como pesquisador de sua prática em um trabalho conjunto com os alunos. $\mathrm{O}$ autor pretende explicitar que os pesquisadores externos nem sempre 
estão integrados ao trabalho realizado em ambiente pedagógico e muito menos envolvidos com os participantes da pesquisa. Dessa forma, a pesquisa de terceiros (cf. third party research) se opõe à pesquisa do praticante. Na pesquisa de sala de aula, os praticantes - professores e alunos - são agentes construtores de seus saberes e trabalham/refletem juntos.

Pode-se dizer que nesta forma de pesquisa do praticante não buscamos soluções imediatas para os problemas nem ações que levem a mudanças. Há, sim, a oportunidade de querer questionar, refletir e buscar entendimentos locais e situados para as questões que surgem no contexto dos praticantes.

A Prática Exploratória que conhecemos hoje integra pedagogia e pesquisa; possibilita o desenvolvimento pessoal e profissional; leva ao trabalho conjunto de professores e alunos em suas buscas por maiores entendimentos de suas questões; constitui uma forma de pesquisa colaborativa dos praticantes investigando e refletindo suas práticas.

\section{2. \\ O Grupo da Prática Exploratória do Rio de Janeiro}

Inicialmente, o Grupo da Prática Exploratória do Rio de Janeiro (MILLER; CUNHA, 2009 p. 216-234) não tinha um lugar para os encontros. As reuniões aconteciam nas casas dos participantes, em restaurantes, durante conferências, seminários e workshops. Atualmente, os encontros acontecem mensalmente na PUC-Rio, "por ser o local onde muitos participantes do grupo estudam e trabalham em diversas instâncias ligadas, em diversos níveis, ao trabalho da PE [Prática Exploratória]" (EWALD, 2015, p. 59). Também no campus PUC-Rio, anualmente, o Evento da Prática Exploratória, o qual envolve alunos, professores e outros profissionais que se dedicam à apresentação de pôsteres, organização de oficinas, entre outros trabalhos. Os pôsteres são "um recurso físico que caracteriza[m] nossa identidade [...] nos quais professores, alunos e outros profissionais registram e compartilham seus entendimentos sobre suas questões" (ibidem).

O Grupo da Prática Exploratória não encontra-se ligado a nenhuma instituição específica e é integrado por professores ativos e aposentados de diversas escolas e segmentos de educação, que se reúnem desde 1994 para 
compartilhar suas experiências de vida em sala de aula, refletir sobre suas questões, discutir publicações e textos referentes à Prática Exploratória. O número de participantes nas reuniões mensais pode variar, mas todos que chegam ao encontro são bem vindos e acolhidos pelos demais integrantes e pelas mentoras do Grupo, Inés Kayon de Miller e Maria Isabel Azevedo Cunha. Para as mentoras, (ALLWRIGHT; HANKS, 2009, p. 221),

encontramos no nosso grupo espaço para, em nossas vidas pessoais e profissionais, exercitar a tolerância da ambiguidade e o respeito pela complexidade - aspectos que geralmente são esquecidos em nossos contextos de trabalho (tradução em EWALD, 2015, p. 62-63).

Encontramos no Grupo, também, espaço para compartilhar textos e livros, preocupações e alegrias, planos e sonhos. Uma característica do Grupo é a disposição para incluir com afeto os participantes, tanto aqueles que estão somente de passagem quanto aqueles chegam para pertencer por bastante tempo.

Segundo Cunha (comunicação pessoal, 13 de novembro de 2018),

no Grupo da Prática Exploratória partilhamos comida que trazemos enquanto acolhemos pensamentos, vivências, experiências de trabalho, produções acadêmicas, projetos e ideias. Parece um ambiente onde se respira afeto e onde se deseja que as reuniões sejam sempre um espaço para falar e ser ouvido. Onde se espera encontrar um espírito proativo para as sugestões e onde se sabe bem pouco das respostas prontas mas muito do imprevisível e do desconhecido.

Nesse sentido, inclusão, afeto, escuta atenta, respeito, flexibilidade, tolerância, colegialidade, desenvolvimento mútuo e ética caracterizam o Grupo da Prática Exploratória como uma comunidade que permanece unida em torno dos princípios que norteiam os praticantes exploratórios em diversos contextos.

\section{3. \\ Os Princípios da Prática Exploratória}

A Prática Exploratória nos oferece um conjunto de princípios éticos e crítico-reflexivos elaborados inicialmente por Allwright (ALLWRIGHT; MILLER, 2001; ALLWRIGHT, 2003, p. 128-130; MILLER et al., 2008, p. 147; MILLER; CUNHA, 2017, p. 67), os quais são discutidos e revistos constantemente pelo grupo de praticantes. Vale esclarecer que os princípios refletem o trabalho contínuo, dinâmico e sustentável da Prática Exploratória e 
que, por não possuírem uma ordem hierárquica, não costumam ser numerados pelos praticantes exploratórios.

Os Princípios que norteiam minhas práticas como professorapesquisadora-praticante são:

- Priorizar a qualidade de vida

- Trabalhar para entender a vida na sala de aula ou em outros contextos profissionais

- Envolver todos neste trabalho

- Trabalhar para a união de todos

- Trabalhar para o desenvolvimento mútuo

- Integrar este trabalho com as práticas de sala de aula ou com outras práticas profissionais

- Fazer com que o trabalho para o entendimento e a integração sejam contínuos

O primeiro princípio reflete a motivação desta pesquisa, que é priorizar a qualidade de vida na sala de aula no contexto do Programa Bilíngue. Sem dúvida, essa intenção movimenta meu trabalho como professora. $\mathrm{O}$ segundo, é a busca de entendimentos locais que pertencem ao grupo, em um recorte histórico-temporal. Essa busca visa enriquecer o nosso trabalho como praticantes independentemente de estar realizando uma pesquisa ou não. $O$ terceiro, o quarto e o quinto relacionam-se ao envolvimento das crianças como atores participantes e ao meu como professora praticante que, conjuntamente, refletimos e buscamos entendimentos para nossas questões locais. A construção mútua de entendimentos acontece nas e durante as interações dentro e fora da sala de aula. O sexto diz respeito ao fato da dissertação, como pesquisa, estar integrada ao cotidiano pedagógico e às vivências educacionais de todos os participantes, o que pode ser melhor entendido com as Atividades Pedagógicas com Potencial Exploratório nos capítulos 5 e 6 . O sétimo princípio reflete a visão de que os entendimentos são localmente construídos em eventos sociais e que envolvem agentividade, criatividade e seriedade em uma busca conjunta e contínua, refletindo a sustentabilidade do trabalho. 
Referindo-se à Prática Exploratória "como um fio filosófico, teórico e ético", Moraes Bezerra (2007, p. 45), afirma que

seus princípios lhe atribuem o aspecto 'multicolorido' por permitirem uma miríade de possibilidades de se lidar com as cores e os desenhos que podem representar a vida em sala de aula e no grupo de reflexão: afetividade, cognição, relação com o outro, crenças, poder, etc.

Ao retratar o "aspecto multicolorido" dos princípios da Prática Exploratória, a autora, em sua tese de doutorado, corrobora com as variadas possibilidades de gerar entendimentos no/do fazer pedagógico. Estes princípios guiam, também, a prática pessoal e profissional da pesquisa do praticante exploratório.

A seguir, discorro a respeito de alguns tópicos, para mim, essenciais contidos nos princípios visando maiores entendimentos por parte do leitor a respeito da Prática Exploratória.

\subsection{1. \\ Sobre qualidade de vida}

As relações na escola e na sala de aula são permeadas por questões sociais, culturais e afetivas. Como professora praticante, acredito que, ao criar um ambiente com oportunidades para o diálogo e a reflexão, estou contribuindo para a qualidade de vida, que sob a ótica da Prática Exploratória, pode ser entendida "como um processo e não um produto, como uma experiência e não como um resultado" (GIEVE; MILLER, 2006, p. 40). Apesar do termo não se restringir à sala de aula, qualidade de vida é, e tem sido, a preocupação central para os praticantes exploratórios em contextos pedagógicos variados. Esta noção de qualidade de vida revela a importância dos entendimentos individuais e pessoais, situados sócio-historicamente. É um processo vivenciado e construído por professores e alunos, levando-se em consideração a interseção da vida pessoal e profissional.

Segundo Allwright (2006, p. 14), a qualidade de vida é importante "para a saúde mental da humanidade a longo prazo (e a saúde mental dos professores de línguas!)". A percepção acerca da qualidade de vida depende de construções individuais e coletivas, as quais podem variar de grupo para grupo. Qualidade de 
vida para os sete alunos participantes encontra-se intrinsicamente relacionada ao contexto sócio-histórico-econômico-cultural que vivenciam, acrescido de suas experiências emocionais e afetivas. Nesse sentido, Souza (2018, p. 41), em sua dissertação de mestrado, discorre que não é "possível estabelecer concepções definidas a respeito do que é qualidade de vida para cada membro que integra os grupos". Acrescento que não é possível devido à complexidade do ambiente da sala de aula e à diversidade de interações que lá acontecem. Essa diversidade pode também estar relacionada às questões que surgem situadas e localizadas em cada grupo de praticante.

\subsection{2.}

\section{Sobre as questões instigantes ou puzzles}

$\mathrm{Na}$ Prática Exploratória, a questão instigante (cf. puzzle) "representa a nossa preocupação em desenvolver entendimentos em relação a assuntos de interesse imediato, sejam eles problemáticos ou não, ligados a uma teoria ou não" (ALLWRIGHT; HANKS, 2009, p. 176). Como os praticantes exploratórios podem estar envolvidos na vida da sala de aula, questões instigantes surgem/emergem do professor, dos alunos, de um único aluno, ou ainda do grupo. Segundo Nóbrega-Kuschnir e Machado (2003, p. 170), as questões instigantes são uma maneira de "os praticantes colocarem em palavras suas preocupações, curiosidades, sentimentos, emoções dentre outros aspectos que constroem a complexidade da natureza humana" para refletir conjuntamente buscando maiores entendimentos.

Com o intuito de facilitar nosso entendimento sobre o que é uma questão instigante, Allwright (HANKS, 2017) recomenda que troquemos o 'como' de nossas perguntas por 'por que'. Assim, ao invés de um problema teremos uma questão instigante. Algumas questões ou puzzles que surgiram no contexto dos praticantes exploratórios: "Why do we have homework?, Why do we cheat?, Why do we use nicknames?, Why is English important for you?, Why do we quit?" (MILLER; CUNHA, 2019, p. 585); "Por que tem tantas língua diferentes no mundo?, Por que temos que aprender inglês?" (CUNHA, 2003); “Why do my students fall asleep in class?, Why can't my students learn to spell?” (HANKS, 2017, p. 233). Estes exemplos revelam dúvidas, preocupações e curiosidades que 
surgiram em salas de aula e que professores e alunos buscaram entender em conjunto.

Um aspecto importante é que as questões nem sempre estão relacionadas a problemas dos praticantes, podendo ser questões positivas que surgem no cotidiano como "Você vai ser nossa professora o ano que vem? e Por que somos felizes nas aulas de inglês da turma 1701?" (EWALD, 2015, p. 51). Essas questões reflexivas não buscam por soluções, resultados, respostas ou mudanças, mas sim podem ser compreendidas como oportunidades de ensino, de aprendizagens e de troca para o grupo.

As questões ou puzzles nos conduzem ao desenvolvimento de atividades reflexivas compartilhadas pelos praticantes exploratórios pelo desejo da busca de entendimentos.

\subsection{3. \\ Sobre a busca de entendimentos}

Segundo Miller (2017, p. 105), “o cerne da Prática Exploratória é buscar entender questões propostas por professores, futuros professores, [coordenadores, diretores] e alunos, e não resolver problemas". Na Prática Exploratória, trabalhamos para entender as questões instigantes (cf. puzzles) que são relevantes em contextos pessoais e/ou de ensino e de aprendizagem. Desse modo, o que mais importa no processo de trabalhar para entender é a conscientização (cf. awareness) que trazemos para nossas práticas como professores e alunos, mas, principalmente, como seres humanos. Allwright e Hanks (2009, p. 173) sugerem que a ação para entender envolve "refletir e fazer" (cf. thinking and doing). Essa ação acontece de maneira contínua, initerruptamente, como um espiral que não tem fim, pois uma questão pode levar a outras.

Para Miller (2012, p. 325),

Na prática exploratória, a investigação é considerada um amplo 'trabalho para entender' as questões relevantes para os agentes e que se realiza de forma integrada à própria prática profissional e de forma conjunta, com outros praticantes envolvidos.

A autora citada aponta que a busca por entendimentos é colaborativa, ou seja, uma forma solidária de pesquisar que envolve os aspectos da inclusão e da sustentabilidade. Segundo Allwright (2003), o trabalho para entender a vida na 
sala de aula deve ajudar professores e alunos "a tornar seu tempo juntos agradável e produtivo". Dessa maneira, o trabalho para entender deve ser parte das ações pedagógicas do professor, no cotidiano da sala de aula, visando a integração de todos.

\subsection{4. \\ Sobre a integração}

O conceito de integração encontra-se presente nos princípios da Prática Exploratória: "integrar este trabalho com as práticas de sala de aula ou com outras práticas profissionais" e "fazer com que o trabalho para o entendimento e a integração sejam contínuos”. Segundo Miller e Cunha (2019, p. 584), “integração consiste na espinha dorsal" (cf. backbone) da Prática Exploratória, ou seja, a base na qual os praticantes se apoiam para trabalhar na busca de entendimentos para suas questões. Para o praticante exploratório, integrar abrange:

- Integrar a vida na sala de aula com a vida fora da sala de aula

O que separa dentro e fora da sala de aula são apenas paredes de tijolo, vidro ou madeira. As paredes não impedem que os sentimentos, os pensamentos, as dúvidas, as ideias, os afetos, as emoções, as questões transitem de um lado ao outro. A vida não fica esperando do lado de fora para a aula acontecer. Assim, o praticante exploratório trabalha para integrar a vida dentro e fora da sala de aula.

- Integrar para promover a aceitação do outro

Além das paredes físicas, existem outras que nem sempre são visíveis. São barreiras pessoais, sociais, econômicas, culturais, religiosas, raciais, ideológicas que podemos encontrar tanto na sala de aula quanto fora dela. Até mesmo em uma aula ao ar livre professores e alunos convivem com preconceito, intolerância, discriminação e conflitos em diferentes níveis. A integração acontece de forma subjetiva e particular. Como professora, posso acreditar que um aluno encontra-se integrado ao grupo, mas esse mesmo aluno pode não se sentir integrado. Ao buscar entendimentos locais e situados para as questões do grupo, o praticante exploratório trabalha para tentar integrar e incluir cada participante.

- Integrar professores e alunos 
As interações pessoais e profissionais que acontecem na escola também ultrapassam seus muros e paredes. A comunidade escolar é sustentada em uma teia de relações: professor-aluno, aluno-aluno, professor-família, aluno-família, professor-coordenação-direção, aluno-coordenação, aluno-funcionário, professorfuncionário e muito mais. A integração na comunidade escolar é construída nas relações humanas, na habilidade de estabelecer e manter conexões e no afeto. As relações entre professores e alunos são permeadas por afeto. Nos anos iniciais da escolarização, as trocas afetivas envolvem não somente o contato físico como abraços e beijos, comuns em nossa cultura, mas também, o modo de falar e de fazer elogios, o reconhecimento pelo esforço e a dedicação de cada aluno, a ajuda e o acolhimento quando o aluno precisa, o olhar carinhoso e a escuta atenta, a bronca e as conversas sérias e reflexivas.

- Integrar a ação para entender com os tópicos dos conteúdos programados do currículo

O professor praticante entende a aula como um processo e não um produto. Mesmo nos ambientes em que o professor deve apresentar conteúdos, fazer avaliações, cumprir prazos é possível buscar entendimentos sobre questões relevantes para o grupo e refletir em conjunto. Segundo Palmer (2012), os professores tecem conexões entre eles, suas matérias e seus alunos e essa conexão é feita pelo coração e não pelos métodos.

\section{- Integrar pesquisa e pedagogia}

A Prática Exploratória é uma atividade pedagógica, por mim entendida como uma maneira de ser e estar na sala de aula. Para os praticantes, integração envolve a possibilidade de integrar a pesquisa acadêmica (ou não) ao que acontece na prática de sala de aula e de integrar a busca por entendimentos ao ensino e a aprendizagem de um determinado conteúdo. Nesse sentido, integração refere-se ao trabalho de sala de aula e diz respeito ao grupo que trabalha para entender suas questões de forma colaborativa. Como professora-pesquisadora-praticante, sinto que não existe separação entre minha pesquisa acadêmica e minha prática pedagógica. As duas coexistem. Não paro as aulas para fazer pesquisa e, por outro lado, não preparo aulas para incluir na pesquisa acadêmica. Uma maneira de 
integrar a pesquisa ao fazer pedagógico diário é monitorar (cf. monitoring) o que acontece na sala de aula, como veremos a seguir.

\subsection{5.}

\section{Sobre o processo de monitorar a vida na sala de aula - monitoring}

Para Allwright (1996; 1999), uma maneira de buscar entender uma questão instigante que surge no ambiente pedagógico da sala de aula, por exemplo, pode começar pela escuta atenta e observação cuidadosa (cf. monitoring). Para o autor, monitorar "é o que faço quando quero aprender sobre o que está acontecendo enquanto estou lecionando". Ou seja, o professor atento, observando o que acontece na sala de aula em relação ao ensino, à aprendizagem e às interações sociais. Esta ação não invasiva (cf. unintrusive) pode ser feita à distância enquanto os alunos estão envolvidos em tarefas da rotina escolar, seja em trabalhos em grupo ou individual. $\mathrm{O}$ autor também sugere anotações mentais (cf. mental notes) enquanto os alunos estão falando.

Da forma como entendo, monitoring é um conceito que envolve, no mínimo, os sentidos da visão e da audição para observar, perceber e escutar a vida na sala de aula. Monitoring é uma maneira de estar presente e alerta (cf. aware) e, ao mesmo tempo, ser capaz de registrar o que acontece no contexto pedagógico e interacional da sala de aula. Ao monitorar sua sala de aula, acredito que o professor pode ampliar a observação e expandir a escuta para buscar entender melhor as questões que emergem no ambiente. Dessa forma, monitorar as interações pedagógicas requer "intenção, atenção e atitude" (SHAPIRO, 2009). A intenção relaciona-se à participação; a atenção refere-se a estar presente no momento; e a atitude diz respeito à ação, à forma de agir, mas não de controlar por parte do professor-praticante. Contudo, acho pertinente considerar que mesmo tendo intenção, atenção e atitude, existem muitas coisas que acontecem na sala de aula que escapam da minha percepção de professora, ou melhor, não consigo ver tudo, ouvir tudo e mais ainda não sei o que se passa em cada aluno em nível mais profundo. Reconhecer essa limitação nem sempre é fácil para o professor.

$\mathrm{Na}$ minha prática cotidiana, monitorar o que acontece na sala de aula envolve ação e reflexão. O fazer, muitas vezes nos conduz às Atividades Pedagógicas com Potencial Exploratório e o refletir nos leva ao processo da busca 
de maiores entendimento sobre as questões que surgem nas interações do grupo dos praticantes.

\section{4.}

\section{Os alunos na pesquisa - agentividade}

Pesquisar a vida na sala de aula tem como foco a ação para entender (cf. action for understanding, ALLWRIGHT, 2001, p. 118) e se baseia na reflexão e na agência. É um tipo de pesquisa inovadora e inclusiva, já que envolve alunos e professores na ação investigativa em torno de questões instigantes que motivam e sensibilizam o grupo. Esse fazer investigativo se caracteriza como "uma reinvenção da vida na sala de aula" (MILLER, 2012, p. 323). Segundo Barreto et al. (2019), as Atividades Pedagógicas com Potencial Exploratório apresentam os seguintes aspectos: orientação ética, centralidade no cotidiano, noção de oportunidade, orientação exploratória, postura crítico-reflexiva, implicação pedagógica e hibridez discursiva.

As Atividades Pedagógicas com Potencial Exploratório caracterizam-se como atividades da rotina escolar que podem ser usadas, com pequenas adaptações ou não, para ajudar a entender as questões que surgem na sala de aula. Assim, atividades comuns no ensino e na aprendizagem de inglês como gramática, vocabulário, leitura e compreensão de texto, produção textual, trabalhos em grupo ou pares, entrevistas, jogos, brincadeiras, entre outras nos permitem investigar questões que emergem do/no grupo e pesquisar a vida na sala de aula. As Atividades Pedagógicas com Potencial Exploratório possibilitam um fazer investigativo ético-reflexivo-inclusivo.

Nos capítulos 5 e 6, incluo três Atividades Pedagógicas com Potencial Exploratório, as quais ilustram que juntos, os alunos e eu, temos a intenção de buscar entendimento sobre a vida no Programa Bilíngue da escola.

Entendo a participação ativa dos sete alunos em várias etapas do processo de construção nesta dissertação como fundamental. A começar pelas conversas que tivemos, antes mesmo de seus consentimentos formalizados nos termos assinados (Anexos), nas quais expliquei o que significava participar da pesquisa. Depois, pelo entusiasmo demonstrado, o qual foi verbalizado, diversas vezes, 
principalmente, por Giovana, Gael, Bruna e Tito. Aponto ainda para o senso de responsabilidade e uma vontade de se engajar em algo que era novo para o grupo.

De acordo com Allwright (2005, p. 358), a pesquisa do praticante aborda a questão da agentividade e "oferece uma nova perspectiva na relação entre os que alcançam entendimentos [os praticantes] e os que tentam usá-los [pesquisadores de fora]". Em outras palavras, a pesquisa do praticante valoriza a autonomia dos professores e dos alunos como pesquisadores de sua prática. As crianças são capazes de participar ativamente e contribuir para pesquisa e este envolvimento está diretamente relacionado às Cinco Proposições (ALLWRIGHT; HANKS, 2009, p. 5-7):

Proposição 1: Os aprendizes são indivíduos únicos que aprendem e se desenvolvem melhor de acordo com suas próprias idiossincrasias.

Proposição 2: Os aprendizes são seres sociais que aprendem e se desenvolvem melhor em um ambiente de apoio mútuo.

Proposição 3: Os aprendizes são capazes de levar a aprendizagem a sério.

Proposição 4: Os aprendizes são capazes de tomar decisões independentemente.

Proposição 5: Os aprendizes são capazes de se desenvolverem como praticantes da aprendizagem.

A primeira proposição refere-se à individualidade e singularidade de cada aprendiz (cf. learners) - professores e alunos - no seu processo de construção do conhecimento. Os sete alunos da turma serão reconhecidos, na pesquisa, por suas histórias individuais, suas potencialidades, características e necessidades. A segunda proposição remete ao fato de sermos seres sociais e que apesar da aprendizagem ocorrer internamente, essa depende também de um ambiente externo onde as trocas e interações favorecem o processo de socioconstrução da linguagem na sala de aula, onde os sete alunos convivem diariamente entre si e com as professoras. A terceira proposição destaca a capacidade dos alunos de dar importância aos seus estudos e aos momentos de aprendizagem. Observei que os sete alunos demonstram levar a aprendizagem a sério. Na quarta proposição, os autores apontam que os alunos são agentes de sua aprendizagem e capazes de decidir como aprender, onde e quando. Percebi autonomia por parte dos alunos no contexto da sala de aula. A quinta proposição engloba as anteriores e coloca o 
aluno como aquele que age, pensa, decide, faz escolhas, enfim, como praticante e agente na sala de aula, na escola e na pesquisa.

Vejo os sete alunos como colaboradores capazes de participar em várias etapas da pesquisa porque acredito que "por trás da mão que pega o lápis, dos olhos que olham, dos ouvidos que escutam, há uma criança que pensa" (FERRERO, 1985, p. 68) e que sente, que interage com o mundo, que busca entender o que está a sua volta. Em sua tese de doutorado, em Prática Exploratória, Ewald (2015, p. 47), sugere que "a criança em um contexto sociocultural constrói ativamente seu conhecimento, sua habilidade e seus comportamentos por meio da comunicação e da troca com o outro". Desse modo, a participação dos alunos na pesquisa, refletindo e compartilhando seus entendimentos, enriquece meu olhar de professora-praticante e pesquisadora. Souza (2018, p. 35), em sua dissertação de mestrado, aponta que "contar com a colaboração dos alunos como agentes ativos no trabalho investigativo é agregar outras perspectivas". Concordo com a autora e acrescento que a participação dos sete alunos agrega cor e encanto à seriedade da pesquisa acadêmica.

A agentividade e/ou a não agentividade dos aprendizes - alunos e professores - nos remete ao mestre brasileiro Paulo Freire. Na próxima seção, proponho um diálogo entre Paulo Freire e Dick Allwright.

\section{5. \\ Dick Allwright e Paulo Freire}

Dick Allwright revela ter sido influenciado por Paulo Freire ao responder a seguinte pergunta formulada por Judith Hanks (HANKS, 2017, p. 327) "Você diria que Freire foi alguém que influenciou seu pensamento?" (cf. So would you say that Freire was somebody who influenced your thinking?). A resposta foi afirmativa (cf. yes).

Baseada em meus estudos e em minhas leituras, acredito que Paulo Freire e Dick Allwright têm muito em comum no que diz respeito à agentividade tanto do professor quanto do aluno no contexto pedagógico/educacional. Acho pertinente antecipar que este é um aspecto relevante para a análise dos dados apresentados, no capítulo 7. 
Segundo Freire (1979[1974], p. 67-68), na concepção da educação bancária,

a) o educador é o que educa; os educandos, os que são educados;

b) o educador é o que sabe; os educandos, os que não sabem:

c) o educador é o que pensa; os educandos, os pensados;

d) o educador é o que diz a palavra; os educandos, os que a escutam docilmente;

e) o educador é o que disciplina; os educandos, os disciplinados;

f) o educador é o que opta e prescreve sua opção; os educandos, os que seguem a prescrição:

g) o educador é o que atua; os educandos, os que têm a ilusão de que atuam, na atuação do educador;

h) o educador escolhe o conteúdo programático; os educandos, jamais ouvidos nesta escolha, se acomodam a ele;

i) o educador identifica a autoridade do saber com sua autoridade funcional, que opõe antagonicamente à liberdade dos educandos; estes devem adaptar-se às determinações daquele;

j) o educador, finalmente, é o sujeito do processo: os educandos, meros objetos.

$\mathrm{Na}$ educação bancária, criticada por Freire, o professor assume a postura ativa como transmissor e detentor do conhecimento, enquanto o aluno aceita passivamente o 'depósito' do conhecimento. Nesse tipo de prática, os conteúdos são desarticulados do contexto, a comunicação é unilateral, e a criatividade é anulada. Em contrapartida, a "educação libertadora, problematizadora" de Freire (1979[1974], p. 78), uma visão mais humana da educação, abre espaço para o questionamento, para a reflexão e para o diálogo. Freire ([1996] 2018a, p. 38-39) aponta que,
A grande tarefa do sujeito que pensa certo não é transferir, depositar, oferecer, doar ao outro, tomado como paciente de seu pensar, a inteligibilidade das coisas, dos fatos, dos conceitos. A tarefa coerente do educador que pensa certo é, exercendo como ser humano a irrecusável prática de inteligir, desafiar o educando com quem se comunica, a quem comunica, a produzir sua compreensão do que vem sendo comunicado. Não há inteligibilidade que não seja comunicação e intercomunicação e que não se funde a dialogicidade. O pensar certo, por isso, é dialógico e não polêmico.

Nesse trecho, Freire retoma os conceitos de educação bancária e educação libertadora registrados primeiramente em Pedagogia do Oprimido, o livro que escreveu em 1968 enquanto exilado no Chile, que foi publicado pela primeira vez nos Estados Unidos em 1970, em Portugal em 1972 e no Brasil em 1974. Na educação libertadora, a comunicação entre educador e educando é um ponto central. Destaco que "a irrecusável prática de inteligir" seria a prática de 
compreender, de entender o educando através dos diálogos, que Freire propõe como prática pedagógica. O diálogo aproxima o educador e o educando, tornando-os sujeitos-agentes do processo de construção da aprendizagem. Ao dialogar, educadores e educandos passam a interagir em igualdade e a refletir sobre si mesmos e sobre o mundo ao seu redor. Em congruência com esse pensamento, os praticantes exploratórios buscam entendimentos localizados e situados sócio-historicamente em atitudes questionadoras, reflexivas, coconstruídos pelo diálogo entre os participantes.

Apesar de, nos textos freinianos, encontrarmos as palavras 'educador' e 'educando', ambos se misturam e se unem no processo de educação. "Já agora ninguém educa ninguém, como tampouco ninguém se educa a si mesmo: os homens se educam em comunhão, mediatizados pelo mundo" (FREIRE, 1979[1974], p. 79). O autor aponta para a ideia de que a educação é um processo social, coletivo que envolve cooperação, colaboração e empatia, o que, pode ser relacionada à Proposição 2: Os aprendizes são seres sociais que aprendem e se desenvolvem melhor em um ambiente de apoio mútuo (ALLWRIGHT; HANKS, 2009, p. 5). Desse modo, no processo de educar-se, os sujeitos-participantes educam e se educam, ensinam e aprendem, desenvolvem e se desenvolvem conjuntamente e em comunhão e diálogo uns com os outros.

Para Freire, (1979[1974], p. 94) diálogo é amor. Sobre o conceito de diálogo, Costa (2018, p. 146) esclarece que

a visão freireana tem o diálogo como uma relação horizontal em que ambos os lados - educador e educando - se colocam numa relação de confiança, de aposta, de reconhecimento do outro. Essa relação precisa estar fundamentada no amor, na humildade e na fé (fé no sentido de acreditar no outro, na sua potencialidade) para que se possa de fato chegar a uma educação pautada na liberdade e na emancipação.

A relação horizontal, apontada pelo autor em sua tese de doutorado, encontra-se em oposição à relação vertical da concepção bancária da educação. Nesse sentido, o diálogo como relação horizontal entre educador e educando refere-se ao encontro, ao amor, à empatia, à confiança, ao entendimento. Essa relação horizontal é, por mim, percebida nos encontros do Grupo da Prática Exploratória, nos quais os integrantes vivenciam uma atmosfera de confiança 
mútua (cf. mutual trust, ALLWRIGHT, 2009a). É o que busco fazer em minha prática diária com os alunos, nas interações face a face do cotidiano escolar.

Retomo, então, à questão da agentividade. Entendo que Freire e Allwright enfatizam a questão, mesmo tendo vivências em contextos sócio-históricopolítico-culturais diferentes. De acordo com minha leitura, Paulo Freire ultrapassa a sala de aula e as relações professor/aluno para abordar relações em um nível macro com viés político e crítico, visando uma transformação na sociedade no que se refere às relações entre opressores e oprimidos, a relação professor/aluno é um exemplo. De forma um pouco diferente, Dick Allwright enfatiza aspectos pedagógicos e filosóficos ao enfocar a vida na sala de aula, apresentando uma visão mais holística do contexto educacional, a qual não deixa de ser política e crítica. Para mim, ao considerar tanto o professor quanto o aluno como aprendizes (cf. learners), Allwright abandona a visão binária, que separa educador e educando, entendendo ambos como agentes. Nesse sentido, os dois autores parecem compartilhar o mesmo pensamento. Segundo Freire (2018[1996], p. 28), "nas condições de verdadeira aprendizagem os educandos vão se transformando em reais sujeitos da construção e da reconstrução do saber ensinado, ao lado do educador, igualmente sujeito do processo". Para mim, esse é um ponto relevante na pesquisa do praticante: professor e aluno como sujeitos, ou seja, agentes de sua busca por entendimentos e conhecimentos.

Ao analisar discursivamente os dados gerados nas conversas exploratórias entre os alunos participantes e eu, no capítulo 7, retomarei à concepção da educação bancária de Freire e às Cinco Proposições de Allwright. Por ora, situo a Prática Exploratória no contexto da pesquisa do praticante.

\section{6. \\ A pesquisa do praticante}

Pesquisa do praticante (cf. practitioner research) é o termo usado para se referir a formas de conduzir uma pesquisa, que apesar de apresentarem diferenças nos aspectos metodológicos e epistemológicos, compartilham muitos pontos em comum. Hanks (2017, p. 28-30) compara estes modos de fazer pesquisa aos membros de uma família, na qual cada membro possui um DNA parecido, mas, 
ao mesmo tempo, uma identidade distinta e singular. Um membro desta família é a Prática Exploratória.

Baseada em Cochran-Smith e Lytle (2009, p. 41-45), relaciono algumas características da pesquisa do praticante:

- linha tênue entre teoria e prática

- o praticante como profissional atuando em um contexto de trabalho e ao mesmo tempo investigando/pesquisando sua própria prática, sem pesquisador de fora

- questões que emergem da prática diária são o foco da reflexão na pesquisa

- o praticante trabalha em conjunto com outros membros de sua comunidade

- todos os participantes podem explicar, investigar, explorar, buscar entender e gerar conhecimentos acerca do contexto no qual estão inseridos

- todos os participantes são conhecedores, aprendizes e pesquisadores

- o conhecimento é construído na comunidade local

- geração de conhecimento situado pode ser usado por outros membros da comunidade

As características mencionadas pelas autoras são comuns ao guarda-chuva que abriga a pesquisa do praticante como gênero/modalidade de investigação nos mais diversos contextos. A forma como o praticante escolhe, teoriza, decide, conduz, reflete, entende, interpreta e analisa pode variar de uma modalidade para outra. Veremos no próximo capítulo que qualquer olhar é filtrado por nossas lentes, que "não existem observações objetivas, apenas observações que se situam socialmente nos mundos do observador e do observado - e entre esses mundos" (DENZIN; LINCOLN, 2006, p. 33). Nesse sentido, na pesquisa do praticante, as investigações acontecem de forma subjetiva, ética, crítica e reflexiva.

$\mathrm{Na}$ Prática Exploratória, inscrita na pesquisa do praticante, o professor é considerado aprendiz (cf. learner) em um ambiente no qual professores e alunos buscam entendimentos para as questões (cf. puzzles) que surgem tanto das práticas pedagógicas quanto das interacionais. A intencionalidade da pesquisa pode ser indicada pela observação atenta (cf. monitoring), pelas entrevistas ou conversas exploratórias, pelas atividades (cf. Atividades Pedagógicas com Potencial Exploratório) que registram os acontecimentos/eventos locais e 
situados. Os dados gerados podem variar de acordo com o ambiente pedagógico dos participantes, a faixa etária, as áreas de interesse, as emoções, os conflitos e as aflições de um momento situado em um contexto específico. A forma como os dados gerados são tratados pelos professor-praticante envolve ética, inclusão, integração, colaboração e agentividade.

A possibilidade de reflexão entre os participantes permite que se crie um espaço para a troca, para considerar as emoções, para perguntar porquês, para buscar entendimentos. A Prática Exploratória fundamenta-se em "uma proposta de crescimento de todos os participantes, abre o caminho para que os praticantes façam parte de uma comunidade de reflexão que tem na ação reflexiva educativa uma forma de tentar entender-se e ao mundo social" (MORAES BEZERRA, 2007, p. 74). Em relação ao ensino de língua inglesa no meu contexto de trabalho no Programa Bilíngue, ou seja, meu "mundo social”, a Prática Exploratória possibilita oportunidades de refletir sobre a minha própria prática e de pesquisar a sala de aula colocando-me como professora-agente do saber pedagógico e profissional. Dessa forma, a Prática Exploratória integra o fazer pedagógico com a pesquisa. Como professora-pesquisadora-praticante, compreendo o conhecimento como busca infinita, na qual quanto mais conhecemos mais entendemos que precisamos aprender.

Neste momento, compreendo a Prática Exploratória como (i) uma maneira de ser e de estar na sala de aula; (ii) uma forma de pesquisar a vida na sala de aula; (iii) um modo de ver o aluno como praticante que constrói seus conhecimentos nas interações e trocas, que compartilha das decisões e faz escolhas dentro e fora da sala de aula; (iv) uma maneira de integrar pessoas; e (v) uma forma de ouvir refletir, discutir e buscar entendimentos mais profundos sobre as experiências diárias e de partilhar vivências.

Os conceitos da Prática Exploratória apresentados neste capítulo estão presentes ao longo da dissertação porque entendo que a Prática Exploratória oferece o arcabouço que sustenta todas as etapas da pesquisa por ser uma proposta teórico-metodológica ético-reflexiva. Esta maneira inclusiva, inserida na pesquisa do praticante, me permite entender os sete alunos participantes como geradores de oportunidades e de possibilidades de aprendizados e não como sujeitos passivos.

Antes de passar para o próximo capítulo, considero relevante salientar que situo minha dissertação no campo da Linguística Aplicada e a caracterizo como 
pesquisa do praticante, na qual observo, descrevo, percebo, sinto, analiso, interpreto, reflito acerca de aspectos relevantes do contexto da minha prática na sala de aula. Por se tratar de pesquisa do praticante, minha prática pedagógica/exploratória inclui os alunos em busca por maiores entendimentos de nossas questões e inquietações. No próximo capítulo, foco no embasamento teórico-metodológico da pesquisa. 


\section{3 \\ Afinidades teórico-metodológicas}

Neste capítulo, discorro sobre o embasamento epistemológico e teóricometodológico e sobre as escolhas e os posicionamentos adotados ao longo da pesquisa qualitativa interpretativa que pretendo construir. Apresento os participantes e a escola para situar o leitor no contexto, no qual os dados da pesquisa foram gerados.

\section{1. Posicionamento metodológico}

A pesquisa qualitativa é uma modalidade de investigação que engloba uma diversidade de práticas metodológicas. Trata-se de "um processo interativo influenciado pela história pessoal, pela biografia, pelo gênero, pela classe social, pela raça e pela etnicidade" (DENZIN; LINCOLN, 2006, p. 20). Dessa forma, cada pesquisador situa-se a partir de uma determinada perspectiva e comunidade, tendo o seu olhar filtrado pelas lentes da linguagem e pela sua capacidade de observação. Na pesquisa qualitativa, entendo que as observações são subjetivas, já que a objetividade não existe, que a distinção entre observador/pesquisador e o observado/pesquisado não é clara ou relevante e que todos os participantes estão socialmente e biograficamente situados (BIAR, 2012, p. 61-62). A pesquisa qualitativa, além de subjetiva, é interpretativa, ou seja, "guiada por um conjunto de crenças e sentimentos em relação ao mundo e ao modo como esse mundo deveria ser compreendido e estudado" (DENZIN; LINCOLN, ibidem, p. 34). Em consonância com esse pensamento, Maher (2010, p. 39) aponta que

[...] o pesquisador não registra, simplesmente, o que as pessoas dizem. Nós somos agentes cruciais na micropolítica de elicitação de dados porque nossa própria presença determina, mesmo que em parte, o que os sujeitos pesquisados nos dizem. Além disto, nossa seleção do que é relevante para análise, assim como essa em si, estão contaminadas pela nossa história pessoal, por nosso posicionamento ideológico.

A autora reforça a ideia de que a subjetividade está presente no processo de uma pesquisa. Cada pesquisador fala, analisa, interpreta, entende a partir de uma comunidade social, cultural e histórica. Como professora-pesquisadora em 
contexto acadêmico, entendo que não há neutralidade nas escolhas do tema principal e dos temas emergentes, do referencial teórico, da metodologia, da geração, seleção e análise dos dados. Entendo que uma pesquisa engloba um conjunto de escolhas e recortes. Entre essas escolhas, destaco a importância de pesquisas realizadas por pesquisadores-praticantes, ou seja, pessoas refletindo sobre sua prática e de forma integrada com suas práticas (ALLWRIGHT, 2003). Meu olhar para um determinado contexto pedagógico, como campo de pesquisa, reflete a noção de subjetividade presente no trabalho. No meu caso, minha decisão de investigar com meus sete alunos o nosso contexto pedagógico marca o campo de pesquisa como colaborativo, agentivo e, necessariamente, (inter)subjetivo.

Como a pesquisa qualitativa "atravessa disciplinas, campos e temas" e constitui-se em "um campo de investigação" (DENZIN; LINCOLN, ibidem, p. 16), essa dissertação encontra-se diretamente relacionada ao referencial teórico da Linguística Aplicada como oportunidade de romper fronteiras entre as disciplinas, o que veremos a seguir.

\subsection{1.}

\section{A Linguística Aplicada Contemporânea}

Para efeito de situar a Linguística Aplicada em um contexto histórico, voltaremos aos anos 60, do século passado, começando pelo ano de 1964, data do primeiro Congresso da Associação Internacional de Linguística Aplicada (AILA), fundado em Nancy, na França. Esse, sem dúvida, pode ser considerado um marco importante para o estabelecimento da Linguística Aplicada como disciplina autônoma. Nessa mesma década, no Brasil, merece posição de destaque a professora e pesquisadora, Maria Antonieta Alba Celani, por sua longa trajetória, a qual, talvez, tenha começado com seu doutorado em Letras Anglo Germânicas pela Pontifícia Universidade Católica de São Paulo, conquista pouco comum na época. A professora Celani, em 1970, estabeleceu o primeiro Programa de Linguística Aplicada ao Ensino de Línguas da PUC-SP, posteriormente denominado de Programa de Pós-Graduação em Linguística Aplicada e Estudos da Linguagem. Além de ser o primeiro, esse também foi o único programa no país por 15 anos. Naquela época, os estudos linguísticos privilegiavam a análise de estruturas internas, enfatizando a visão de língua como sistema de regras, desconsiderando 
os usuários da língua. Também associava-se Linguística Aplicada ao ensino de línguas estrangeiras.

Foi no anos 80 que essa visão começou a ser alterada e a Linguística Aplicada passou a adquirir mais autonomia. Essa expansão da área deve-se ao aumento no número de linguistas aplicados nas universidades brasileiras, alguns com doutorados no exterior. Somado a isso, surge o segundo programa de PósGraduação em Linguística Aplicada do país, na Universidade Estadual de Campinas (UNICAMP). Além das pesquisas em nível de pós-graduação, surgiram as revistas: Trabalhos em Linguística Aplicada, em 1983, e Documentação de Estudos em Linguística Teórica e Aplicada (D.E.L.T.A.), em 1985. Também foram criados a Associação de Linguística Aplicada (ALAB) e o Intercâmbio de Pesquisas em Linguística Aplicada (InPLA). Em 1986, realizou-se o primeiro Congresso Brasileiro de Linguística Aplicada (CBLA). Fica claro que a década foi bastante produtiva. Nesse contexto, o linguista aplicado ampliou seus estudos para além das fronteiras do ensino e aprendizagem de línguas e passou a englobar outras questões em sua área de pesquisa, fato que contribuiu para surgimento da Linguística Aplicada como ciência interdisciplinar associada a outras áreas do conhecimento como a Psicologia, a Sociologia, a Antropologia e a Etnografia.

Dessa forma, na década de 90, a Linguística Aplicada passa a ser entendida como uma área de investigação independente da Linguística, mas que se apoia em outras áreas do conhecimento para suporte de suas pesquisas. Conforme afirma Celani (1992, p. 19) "a LA é o ponto, então, onde o estudo da linguagem se intersecciona com outras disciplinas". Em consonância com esse pensamento, Moita Lopes, Fabrício, Rajagopalan, Rampton, entre outros autores (MOITA LOPES, 2006) entendem a Linguística Aplicada como interdisciplinar, mestiça e INdisciplinar.

No século XXI, o linguista aplicado está mais crítico, atento e sensível às preocupações sociais, culturais, raciais, políticas e éticas. À vista disso, observa-se o surgimento de novas tendências de pesquisa em Linguística Aplicada, em contextos múltiplos de investigação. Para Moita Lopes (2006, p. 99), o surgimento dessas novas perspectivas de investigação ocorre em função do entendimento que uma única disciplina não é suficiente para “[...] dar conta de um mundo fluido e globalizado para alguns, localizado para outros, e contingente, complexo e contraditório para todos". Essa perspectiva de pesquisa rompe com os 
limites das disciplinas e com a fragmentação do saber científico, tornando as fronteiras entre as disciplinas mais tênues, o que contribui para uma compreensão mais profunda e abrangente dos problemas estudados, através de um olhar múltiplo, articulando diferentes modos de entender o mundo.

A Linguística Aplicada interdisciplinar compreende a linguagem como sendo essencialmente vinculada às questões socioculturais e sociopolíticas. Dessa forma, a Linguística Aplicada perpassa a construção discursiva do ser, com um olhar para a sociedade. Esse movimento interdisciplinar traduz a busca, em outras disciplinas, por fundamentos, métodos e perspectivas, onde os campos de investigação se entrecruzam e vão além das questões formais da linguagem. Como sugere Jordão (2016, p. 13),

Fazer Linguística Aplicada, em suma, relaciona-se com outras áreas, outros conhecimentos, outras metodologias, outras visões, estabelecendo práticas multifacetadas, plurais, contingentes que se contrastam e contrapõem, exigindo uma abertura constante para negociações.

Assim, reforço que fazer Linguística Aplicada é compreender que a mesma dialoga com outras ciências como Sociologia, Filosofia, Antropologia, Psicologia e Educação. Fazer Linguística Aplicada é compreender que estamos conectados ao conhecimento que produzimos, à "linguagem que usamos" e às "estruturas e instituições nas quais vivemos" (BODILY, 1994, p. 174 apud MOITA LOPES, 2004, p. 167). Fazer Linguística Aplicada é considerar a ética, a inclusão, a pluralidade dos saberes, a subjetividade, o apagamento da linha que separa teoria e prática, o entendimento de que não há neutralidade científica.

Minha maneira de interpretar os atravessamentos de fronteiras disciplinares me permite fazer recortes e escolhas almejando buscar entender questões locais pertinentes à escolarização português-inglês dos meus alunos na sala de aula, numa escola da rede particular, a qual está inserida na sociedade, num contexto cultural, histórico e político, no Estado do Rio de Janeiro, no Brasil. Nesse sentido, situo minha pesquisa na linha tênue entre a Linguística Aplicada e a Pedagogia e busco por entendimentos no contexto escolar, ancorada nos princípios ético-reflexivos da Pratica Exploratória (ALLWRIGHT; HANKS, 2009; MILLER; CUNHA, 2017b). Com foco na vida social e interacional da sala de aula, tenho em mente que "todo conhecimento em ciências sociais e humanas é uma forma de conhecer a nós mesmos e de criar possibilidades para compreender 
a vida social e outras alternativas sociais" (MOITA LOPES, 2006, p. 104). Envolvida na construção de saberes locais e situados, considero, na próxima seção, o viés etnográfico da pesquisa do praticante exploratório. Mas, antes de seguir, busco situar a pesquisa no contexto interdisciplinar da Linguística Aplicada.

Miller (2013) menciona o texto Six Promising Directions in Applied Linguistics (ALLWRIGHT, 2006, p. 11-17), o qual Allwright descreve um perfil histórico da Linguística Aplicada e as mudanças pelas quais passou ao longo dos anos. Reproduzo, a seguir, os tópicos traduzidos por Miller (ibidem, p. 104):

- de uma postura prescritiva a uma postura descritiva, a caminho da busca pelo entendimento;

- das visões simplificadoras em direção ao reconhecimento da complexidade;

- da busca de resoluções generalizantes a problemas gerais no estudo de situações locais e idiossincráticas;

- da precisão como forma ilusória de ensino-aprendizagem à abordagem disseminadora de múltiplas oportunidades de aprendizagem;

- da atribuição das oportunidades de aprendizagem ao trabalho nelas investido à valoração da 'qualidade de vida em sala de aula' onde elas emergem;

- do entendimento dos acadêmicos como produtores de conhecimento à aceitação dos praticantes como agentes de teorizações sobre suas próprias práticas profissionais.

Traçando um paralelo entre as seis direções promissoras citadas com a minha pesquisa, mais especificamente o capítulo 2, acredito que (i) como professora-pesquisadora assumo a postura de busca por entendimentos locais e situados; (ii) a noção de complexidade está relacionada às redes de integração; (iii) na busca por entendimentos situados e localizados e não por respostas, soluções ou generalizações; (iv) professores e alunos são agentes de suas buscas por conhecimento; (v) a qualidade de vida abarca o afeto nas relações e interações como prioridade na sala de aula; (vi) como praticantes exploratórios, o conhecimento construído pelos alunos participantes e por mim são entendidos como oportunidades de aprendizagem.

Após essa reflexão, situo minha dissertação no contexto interdisciplinar e proponho um diálogo entre a Pedagogia e a Linguística Aplicada, considerando os constructos Prática Exploratória, Linguística Sistêmico-Funcional e Sistema de Avaliatividade, destacando o viés etnográfico, a seguir. 


\subsection{2.}

\section{Um viés etnográfico na construção da pesquisa exploratória}

Uma forma de pesquisar a vida na escola e na sala de aula é realizando um trabalho etnográfico, no qual o pesquisador, professor ou não, entra em contato com os participantes e observa as interações no ambiente pedagógico. Robinson (1994), ao realizar seu trabalho etnográfico em quatro turmas de primeiro ano (cf. first grade) em uma escola no estado do Mississipi, destaca como procedimentos de pesquisa a observação participante, as notas de campo, o diário, as filmagens e gravações, as entrevistas com as professoras e com os alunos, os desenhos dos alunos, e a autoavaliação das professoras. Neste tipo de abordagem, o pesquisador deve presenciar o maior número possível de situações do cotidiano, em ambiente natural, por um determinado tempo, reunindo material para suas análises (ANDRÉ, 2012).

Ao refletir sobre minha pesquisa, entendo que existem alguns pontos comuns com a etnografia como o diário, as anotações e registros escritos, as observações atentas, as entrevistas gravadas com os alunos. Outro ponto comum entre uma pesquisa etnográfica e uma pesquisa do praticante é o fato de ambas envolverem a participação e colaboração do grupo. Porém, diferentemente do etnógrafo que vai ao lugar para observar e pesquisar, eu já estou no lugar-escola. Por esta razão, encontro-me envolvida com as práticas diárias do ambiente pedagógico, com os professores e coordenadores que lá convivem, com meus alunos em uma relação diária de proximidade. Dessa forma, observo minha própria prática e acredito que minha pesquisa tem um viés etnográfico no sentido de que foi construída pela minha observação direta e participante por um longo período de tempo, havendo interação constante com o grupo pesquisado. Também compreendo que meu ponto de vista de professora-observadora é um recorte das vivências coconstruídas no lugar-escola, o qual os alunos participantes e eu habitamos.

Como pesquisadora-mestranda, considero que minha pesquisa apresenta características, preferências e marcas individuais, as quais indicam a subjetividade do trabalho. A esse respeito, Velho (2011, p. 178) aponta que "o próprio pesquisador é, em parte, personagem das histórias e das narrativas que colhe", sendo que a realidade "sempre é filtrada por um determinado ponto de vista do 
observador" (VELHO, 1978, p. 43). Desse modo, me entendo como professorapesquisadora da história que pretendo contar com a colaboração dos meus alunos. Certamente, para mim, construir a dissertação na escola na qual trabalho como professora envolve um grande desafio: o de observar e buscar entender melhor o que já é familiar.

Como pesquisadora-praticante, observo minha própria prática, o que envolve fazer, refletir e buscar entender questões do cotidiano, nas quais estou inserida. Neste momento, é assim que me posiciono - com uma lente de aumento para observar o que já me é familiar como praticante, buscando entender a multiplicidade de aspectos que fazem parte do universo cultural do ambiente escolar e, sobre tudo, reconhecendo que meus entendimentos atuais são perspectivados e marcados por traços individuais do meu olhar de pesquisadorapraticante.

Como professora-pesquisadora-praticante, tenho oportunidade de realizar minha pesquisa ao mesmo tempo que atuo como professora, ou seja, não paro as aulas para pesquisar e sim observo com mais atenção o que acontece em minha prática como professora e em minhas relações com os alunos.

Entendo que a pesquisa do praticante exploratório apresenta alguns pontos comuns com a pesquisa etnográfica. Vale ressaltar, então, as diferenças para esclarecer e situar melhor a pesquisa do praticante nesta dissertação. Primeiro, não existe a presença de pesquisadores externos porque acreditamos que o próprio professor é capaz de investigar de forma crítica e reflexiva sua prática pedagógica. Segundo, o professor pode observar/monitorar (cf. monitoring) o que acontece em sua sala de aula de forma não invasiva ou intrusiva. E, terceiro, a pesquisa do praticante envolve todos os participantes em um trabalho para desenvolvimento mútuo, individual e coletivo, sustentável e ético.

\subsection{3.}

\section{A ética na pesquisa}

Nas escolhas epistemológicas que orientam esta dissertação, a ética é uma preocupação constante em cada fase do processo de pesquisa. Entendo as crianças participantes como colaboradoras e não tenho intenção de causar-lhes nenhum 
dano ou prejuízo. Acredito, juntamente com Kramer (2002, p. 45) que, em uma pesquisa,

quando trabalhamos com um referencial teórico que concebe a infância como categoria social e entende as crianças como cidadãos, sujeitos da história, pessoas que produzem cultura, a ideia central é a de que as crianças são autoras, mas sabemos que precisam de cuidado e atenção.

Esse cuidado e atenção por parte do pesquisador se refere à ética presente no posicionamento teórico e nas práticas sociais e profissionais do estudo em foco. No Brasil, tanto a Resolução No 466/12 do Conselho Nacional de Saúde que trata da ética em pesquisa com a participação de seres humanos, de forma direta ou indireta, quanto os Comitês de Ética em Pesquisa têm a criança como pessoa em situação de vulnerabilidade. Tal fato requer uma atenção especial por parte do pesquisador com relação aos princípios orientadores de salvaguarda e respeito pela criança e suas especificidades. Com a finalidade de documentar os cuidados éticos, obtive a permissão assinada pelos responsáveis no Termo de Consentimento Livre e Esclarecido (Anexo 2), o qual explica o tipo de pesquisa, considera os possíveis danos, prevê os procedimentos de proteção do anonimato da criança, informa sobre a possibilidade de desistir, e esclarece sobre o direito de acesso a pesquisa. Outro cuidado ético é o Termo de Assentimento Livre e Esclarecido (Anexo 3), o qual foi lido e explicado para as crianças, antes de assinado pelas mesmas, após o consentimento dos responsáveis.

Reconheço os alunos participantes como atores sociais e sujeitos colaboradores da pesquisa. A participação de cada criança através de textos escritos, desenhos, pôsteres assim como na gravação em áudio de conversas entre os alunos e eu, como professora-pesquisadora, contribuí para reflexões e maiores entendimentos de questões relacionadas ao contexto escolar do Programa Bilíngue. Nenhuma filmagem ou fotografia dos alunos foi incluída como material de pesquisa. Entendo que a pesquisa envolve riscos mínimos como um eventual reconhecimento dos textos escritos ou dos desenhos produzidos pelas crianças. Para minimizar tais riscos, os nomes das crianças foram substituídos por nomes fictícios.

A atuação e aprovação do Comitê de Ética em Pesquisa da PUC-Rio (Parecer $n^{\circ}$ 02/2019 - favorável) foi uma etapa para que as crianças participantes sejam respeitadas durante a produção e divulgação da pesquisa. Dessa forma, os 
cuidados éticos dessa pesquisa envolvem o consentimento, o assentimento, a proteção contra o dano, a confidencialidade e o anonimato da criança. Além dos termos lidos e assinados pelos alunos participantes e seus responsáveis, encontrese nos anexos a carta de anuência, na qual as duas diretoras da escola concordam que a pesquisa seja realizada no espaço escolar por elas dirigido.

\section{2.}

\section{Uma escola habitada há 50 anos}

Ao longo da dissertação vou contar um pouco da história de uma escola que pertence à rede particular de ensino, localizada em um município do Estado do Rio de Janeiro. Escolhi omitir o nome da escola apesar de, em uma conversa com a diretora administrativa, ela haver dito que autorizaria formalmente o uso. Esta escolha está diretamente relacionada à minha intenção de preservar a identidade de todos os participantes, principalmente dos alunos.

Entendo a escola à qual me refiro de duas maneiras: primeiro, como um espaço fisicamente e geograficamente delimitado, passível de uma descrição mais objetiva, por exemplo, a área que ocupa ou o número de alunos. Segundo, como uma "arena de interações" (PRABHU, 1992, p. 225-230), onde histórias de vida, pensamentos, sentimentos e emoções se intercruzam; onde aqueles que habitam a escola se encontram conectados e interligados uns aos outros formando uma teia. Essa parte é subjetiva, pois depende do meu olhar de professora e pesquisadoraexploratória.

Sem dúvida, registrar o que acontece em uma escola, em qualquer tipo de pesquisa, requer recortes e muitas escolhas. Consequentemente, entendo que esta pesquisa, realizada por mim e meus alunos como praticantes exploratórios, está impregnada das minhas/nossas escolhas, crenças e valores, da minha habilidade de ver e reconhecer o que está fora de mim, e do meu olhar de pesquisadora praticante no momento. Considero a escola um organismo vivo, um lugar de interações e de relações humanas, no qual se projetam e (re)constroem identidades múltiplas e fragmentadas (MOITA LOPES, 2006, 2013) assim como especificidades que caracterizam o ambiente e a vida cotidiana. Estas identidades normalmente ficam marcadas no Projeto Político Pedagógico, documento que 
registra os princípios explicitados que norteiam a ação educacional na instituição. Seriam impressões digitais da escola. Cada uma tem as suas.

Dos 50 anos de história, participo dos 17 últimos, mas convivo com as pessoas que idealizaram, sonharam e planejaram os fundamentos da instituição. Não sei se elas imaginaram celebrar os primeiros cinquenta anos da escola juntas e não sei exatamente por quantos percalços e alegrias passaram durante a trajetória. Sei que sempre existiram flores, muitas flores.

No momento atual de plenitude e maturidade, a escola situa-se em uma área de mais de $5000 \mathrm{~m}^{2}$ e possui 530 alunos matriculados da Creche à terceira série do Ensino Médio e conta com um total de 154 funcionários, sendo que 107 são professores. A escola é dirigida por duas pessoas, uma diretora responsável pela administração e uma responsável pela parte pedagógica, ambas assessoradas pela coordenadora geral, que também dá suporte para outros membros da coordenação que formam um grupo de seis profissionais. A coordenação é dividida nas áreas de Língua Portuguesa e Matemática, que englobam Literatura e Artes respectivamente; Educação Infantil; Ensino Fundamental I; Ensino Fundamental II e Ensino Médio. A coordenação denominada de Turno tem a função de fazer mediações entre aluno, família e escola. A coordenação do Programa Bilíngue é responsabilidade da coordenadora geral.

Apesar da hierarquia entre as funções desempenhadas pela direção, coordenação e corpo docente, sinto, como professora, que existe um ambiente de respeito e cooperação assim como de valorização da figura do professor tanto por parte da direção quanto da coordenação. O que atribuo ao fato de todos, diretoras e coordenadores, já haverem vivenciado ou ainda vivenciarem experiências como professores. Nessas relações, também observo que existe uma escuta atenta e um olhar cuidadoso para detalhes, os quais são fundamentais para sobreviver às demandas e às cobranças do calendário escolar. Posso citar como exemplo as visitas que recebo em minha sala de aula da diretora pedagógica, primeiro, se desculpando por não poder estar mais presente, depois perguntando se está tudo bem comigo, com os alunos, e se eu preciso de alguma coisa. Esse ato de compromisso e carinho funciona como um estímulo, um carregador de baterias e faz muita diferença.

Acho importante apontar que, ao longo das etapas da pesquisa, não limiteime a pedir autorização para realizar a pesquisa na escola (Anexo 1 - Carta de 
Anuência), mas sim solicitei a participação das diretoras e da coordenadora geral durante a construção da dissertação, fazendo perguntas relacionadas ao contexto escolar e conversando sobre questões do cotidiano da escola. Na seção seguinte conto, de forma sucinta, minha trajetória na escola ao longo de 17 anos.

\subsection{1.}

\section{O Programa Bilíngue - 17 anos de história}

O que chamamos, hoje, de Programa Bilíngue começou, para mim, quando estava cursando a Complementação Pedagógica em uma universidade privada do Rio de Janeiro, no ano 2000. O trabalho avaliativo de uma das disciplinas envolvia várias etapas, entre elas, visitar uma escola, observar o espaço, entrevistar coordenadores e professores, reunir material e desenvolver um projeto específico para a escola. Na escola, por mim escolhida, fui recebida na secretaria, onde expliquei o tipo de trabalho que estava fazendo e fui encaminhada para uma das coordenadoras, que apresentou todo o espaço, falou sobre a filosofia da escola e gentilmente respondeu a todas as minhas indagações. $\mathrm{O}$ material gerado após a visita deu origem ao trabalho requisitado pelo professor, cujo título foi Projeto Inglês do Maternal à oitava série (como era denominado o $9^{\circ}$ ano naquele momento). Entendo este trabalho como uma semente que já carregava em si um potencial futuro. Dentro da semente encontravam-se muitas ideias que misturavam conhecimento na área de Pedagogia, interesse por letramento bilíngue, prática como professora em um curso de inglês, acrescido de muitas leituras e outros cursos por mim realizados.

No segundo semestre de 2001, no corredor do curso de inglês onde eu trabalhava, uma colega perguntou se eu gostaria de participar, com ela, de uma reunião com a direção de uma escola que intencionava implantar um projeto bilíngue. Quando Ana (nome fictício) disse o nome da escola nem acreditei. Era a escola que eu havia visitado para realizar meu trabalho. A partir daí, foram muitas reuniões e encontros entre a diretora administrativa, a coordenadora geral, Ana e eu. Juntas, planejamos e traçamos as diretrizes do que viria ser o Programa Bilíngue. É fundamental apontar que o projeto foi coconstruído especificamente para a escola, considerando o contexto do ambiente e das famílias. Não houve suporte de pessoas ou instituições de fora da escola. 
Segundo a coordenadora geral (comunicação pessoal, 2015), a implantação do Programa Bilíngue " teve como motivação o fato de avaliarmos a necessidade de proporcionar aos alunos um maior domínio da língua inglesa”. Para mim, a inserção do Programa Bilíngue na escola pode ser justificada pelo fato de a escola estar constantemente se redesenhando diante das transformações da comunidade local. Os desafios movem e tem movido as transformações nessa instituição de ensino.

Oficialmente, o Programa Bilíngue teve início em 2002, quando Ana e eu começamos com duas turmas, sete alunos em cada, levando para escola nossa experiência como professoras de curso de idioma e nossa vontade de desenhar e elaborar o que hoje é o Programa Bilíngue. Foi um processo de construção e muitas aprendizagens para nós duas, repleto de descobertas.

O nome escolhido inicialmente foi Projeto Bilíngue e depois de algum tempo passou a ser chamado de Programa Bilíngue, por decisão da direção e coordenação. No dia a dia da escola, usamos apenas Bilíngue, como por exemplo, a turma do Bilíngue, o horário do Bilíngue e assim por diante. Entendo que talvez não seja a nomenclatura adequada, porém fica claro, no ambiente da escola, que não somos uma escola bilíngue. Observo que muitas escolas da rede privada da cidade usam o termo 'bilíngue' e que esta realidade mercadológica abrange o ensino de inglês no currículo das mais variadas formas. A falta de uniformidade em relação ao termo se estende ao tipo de educação bilíngue disponibilizada, ou seja, umas escolas oferecem aulas com duração de uma hora duas ou três vezes por semana, outras duas horas cinco vezes por semana. Estas escolas adotam variados programas em termos de carga horária, estrutura curricular e metodologia. Assim, umas fazem contratos com institutos de línguas, outras terceirizam o segmento. Já na escola onde trabalho, o Programa Bilíngue foi criado internamente, focando no contexto local e nas particularidades da escola.

Acho importante acrescentar que uma das preocupações da diretora administrativa e da coordenadora geral era que a língua inglesa fosse ensinada e vivenciada dentro da proposta educacional da escola. Por essa razão, Ana e eu tivemos o suporte diário de duas professoras-pedagogas muito experientes na escola, que além de nos ajudar com a rotina da sala de aula e com o almoço dos alunos, nos deram suporte na elaboração de relatórios para os responsáveis, no planejamento das atividades e na familiarização com os conteúdos básicos 
ensinados em cada ano escolar. Tive o privilégio de trabalhar com uma professora especializada em alfabetização e letramento, o que, sem dúvida, contribuiu muito para minha formação profissional e favoreceu maiores entendimentos sobre essa fase importante da escolarização. Esta experiência corrobora com a ideia de que aprende-se a ser professor com outros professores. A noção de formação em serviço, compartilhada por Freire ([1996] 2018a) e Nóvoa (2009), está presente no contexto dos encontros do Grupo da Prática Exploratória da PUC-Rio, conforme mencionado no capítulo 2.

Mesmo sendo uma atividade extra, o Programa Bilíngue segue a proposta pedagógica da escola, a qual se apoia nos pilares: conhecimento, cultura e valores. Em consonância com a filosofia da escola, o Projeto Político Pedagógico do Programa Bilíngue foi criado internamente, de maneira colaborativa para atender, ao mesmo tempo, a cada aluno e a comunidade escolar. As identidades e as diretrizes pedagógicas do Programa Bilíngue transparecem no documento, assim como as características do espaço físico, a carga horária, os recursos humanos, a organização curricular e os materiais didáticos.

No meu entendimento, o ensino de inglês nos anos iniciais de escolarização visa à ampliar horizontes, à promover o desenvolvimento cognitivo e linguístico e à contribuir para formação sociocultural das crianças. No contexto do Programa Bilíngue, a construção de letramentos é prioridade, assim como o respeito às singularidades de cada aluno em suas trajetórias de aprendizagem. De fato, todos estes aspectos constituem a filosofia da escola, e se estendem ao Programa Bilíngue. Para Rojo (2009, p. 12), é papel da escola trazer "para dentro de seus muros não somente a cultura valorizada, dominante, canônica, mas também as culturas locais e populares e a cultura de massa, para torná-las vozes de um diálogo, objetos de estudo e de crítica". Esse é um papel que a escola, onde trabalho, desempenha, dedicando bastante atenção e cuidado.

Assim como nos outros segmentos da escola, o letramento é uma prática nas turmas do Programa Bilíngue tanto da educação infantil quanto do ensino fundamental. Diferente da alfabetização, "ação de ensinar a ler e a escrever" (SOARES, 2004, p. 47), o letramento é o "estado ou condição de quem não apenas sabe ler e escrever, mas cultiva e exerce práticas sociais que usam a escrita." (ibidem). Para Rojo (2009, p. 98), o letramento 
busca recobrir os usos e práticas sociais de linguagem que envolvem a escrita de uma ou de outra maneira, sejam eles valorizados ou não valorizados, locais ou globais, recobrindo contextos sociais diversos (família, igreja, trabalho, mídias, escola etc.), numa perspectiva sociológica, antropológica e sociocultural.

Durante as aulas, as práticas de letramento envolvem a familiarização com as diversas maneiras e contextos, nos quais a língua inglesa é usada - contos de fadas, narrativas, poesias, pinturas, desenhos, quadrinhos, revistas, manual de instruções, entrevistas, embalagens, cardápios, receitas, filmes, música, entre outros. Ressalto que utilizamos materiais autênticos, até mesmos as embalagens e os cardápios usados nas brincadeiras de casinha e restaurante. Sem contar os livros, tema da próxima seção. Sobre o letramento digital, temos computador em cada sala de aula e as turmas de ensino fundamental do Programa Bilíngue têm aulas em inglês no Laboratório de Informática uma vez por semana.

No Programa Bilíngue, os alunos constroem seus saberes nas interações, nas quais participam dentro e fora do ambiente escolar. Segundo Nóbrega (2009, p. 28), "a socioconstrução do conhecimento em sala de aula é feita através do ato discursivo", dito de outra forma, o aluno fica envolvido em um ambiente pedagógico, social e afetivo, no qual entra em contato com o idioma nas interações com as professoras e os colegas, acrescido de outros tantos recursos pedagógicos. Este conjunto de experiências alicerça a construção da linguagem nos contextos pedagógico, linguístico e discursivo. Nesse ambiente pedagógico, a língua inglesa não é tratada como apenas mais uma matéria escolar e sim um meio de vivenciar experiências como brincar de roda, pular corda, seguir receitas nas preparações culinárias, ouvir contos de fadas e fábulas, assistir a vídeos, ouvir música, trabalhar na horta, participar de jogos e brincadeiras dentro e fora da sala de aula, encenar peças de teatro, ler e escrever, observar a natureza, cavar e construir nos pátios de areia.

Ainda referindo-me ao Projeto Político Pedagógico, fica especificado que o Programa Bilíngue é “oferecido em horário complementar, como currículo adicional às 4 horas e 30 minutos do horário regular, tanto na Educação Infantil quanto no Ensino Fundamental do $1^{\circ}$ ao $5^{\circ}$ ano" (texto retirado do documento da escola). Por ser opcional, implica em acréscimo na mensalidade escolar, sendo o almoço incluído como atividade pedagógica. Isso indica que nem todos os alunos matriculados na escola o são também no Programa Bilíngue. Para todos os alunos, 
inglês faz parte do currículo regular desde a educação infantil, com uma aula semanal apenas.

Mesmo não havendo obrigatoriedade de inclusão de língua estrangeira antes do $6^{\circ}$ ano (RIO DE JANEIRO, 2013) tornou-se recorrente o ensino de inglês em escolas particulares, a partir da educação infantil, ficando sob a responsabilidade da instituição definir carga horária, selecionar materiais e adotar metodologia(s). Reconheço o crescimento global e local do ensino de inglês cada vez mais cedo (CAMERON, 2001; PINTER, 2014, 2017; MILLER et al., 2019) e compreendo a necessidade de refletir sobre quem são essas crianças entre 3 e 11 anos assim como quem são esses professores num ambiente pedagógico específico de educação e escolarização bilíngue (BAKER, 2010; GARCÍA, 2009) e sua formação (MILLER, 2013). Contudo, este não é o objetivo da minha dissertação e acredito que o tema poderá ser desenvolvido em futuros trabalhos. Por ora, entendo que a inclusão de inglês nos primeiros anos de escolarização parece estar de acordo com as propostas da escola onde trabalho e atende a uma demanda social e cultural do entorno.

De acordo com Capra (2006a, p. 19), o currículo deve ser construído no local, “o ambiente em que a escola está inserida - a sua geografia, a sua história, a cultura das comunidades do entorno - que devem determinar os conteúdos a serem apreendidos". É possível afirmar que o currículo do Programa Bilíngue se encontra em processo construção desde 2001, pois, ao longo dos anos, vem sendo revisado e discutido pelo grupo de professoras e pela coordenadora geral. A matriz curricular encontra-se dividida nos eixos: formação pessoal e social; disciplinas básicas; e parte diversificada. O primeiro item contempla respeito, cooperação, responsabilidade, autonomia, alimentação saudável e higiene pessoal. O segundo, inclui várias áreas do conhecimento como literatura, história, geografia, ciências e matemática, trabalhadas em gêneros escritos e orais. O terceiro abrange culinária, artes, dramatização, informática, festas e eventos. A matriz curricular oferece orientações para o desenvolvimento de um currículo específico, conectando o conhecimento ao desenvolvimento individual do aluno.

No início do ano letivo, um ou dois dias antes do retorno dos alunos, nós, professores dos três segmentos, educação infantil, ensino fundamental e ensino médio, somos recebidos pelas diretoras e pelos coordenadores com um café da manhã e, em seguida, assistimos à palestra da coordenadora geral que, além das 
boas-vindas, apresenta o projeto anual. O tema do projeto anual unifica e integra todos os segmentos da escola. Na minha interpretação, essa reunião inicial, denominada de Planejamento Escolar em nosso calendário, é um momento de integração dos professores e das áreas de ensino, pois no cotidiano os segmentos são separados e fragmentados. Em outras palavras, mesmo havendo um tema unificador, na rotina escolar, cada coordenador se reúne com seu grupo, os professores tendem a trabalhar e planejar atividades em pequenos grupos ou duplas e os segmentos são divididos nos dias de conselho de classe. Até mesmo nos eventos de confraternização, observo que o agrupamento dos professores acontece em consonância com os segmentos escolares.

O tema anual "não deve engessar o trabalho dos professores, mas sim criar uma sincronia entre a equipe" (coordenadora geral - comunicação pessoal, 01/02/19). Desse modo, cada professora regente do Programa Bilíngue fica responsável por elaborar um planejamento mensal e outro semanal, ambos entregues à coordenadora, que participa com sugestões e orientações. Ao planejar, cada professora tem autonomia tanto para criar e desenvolver os temas que escolheu abordar, quanto para trabalhar em parceria ou em grupo, sempre que encontrar pontos comuns com as outras professoras.

Veremos, a seguir, o papel da Literatura no Programa Bilíngue.

\subsection{2. \\ Uma escola apaixonada por livros}

"É na nossa Biblioteca que o coração [da Escola] bate mais forte" (folheto da escola). Acho que esse texto revela a importância e a valorização da literatura no contexto e na cultura da escola. No Programa Bilíngue, não é diferente. Temos à nossa disposição mais de quinhentos livros dirigidos ao público infantil, todos adquiridos em países de língua inglesa. $\mathrm{O}$ acervo inclui variados gêneros e títulos de autores renomados e premiados da literatura infantil inglesa e americana.

A contação de histórias e a leitura são práticas valorizadas no cotidiano da escola em todos os segmentos. A paixão pela literatura fica registrada nas portas das salas de aula com placas que indicam o nome pelo qual a sala é conhecida, ou seja, nomes como Ana Maria Machado, Bartolomeu Campos de Queirós, Bia Bedran, Ferreira Gullar, Marina Colasanti, Ziraldo, entre outros. A sala de aula 
que os alunos participantes e eu habitamos foi denominada de Eric Carle, em homenagem ao escritor e ilustrador de uma vasta obra dedicada ao público infantil, cujos livros inspiram muitos de nossos trabalhos e atividades, e fazem parte do acervo de nossa biblioteca.

A literatura no Programa Bilíngue está associada ao prazer de ouvir e contar histórias. Contudo, além de envolver os alunos nos momentos mágicos de contação de histórias, os livros do acervo são muitas vezes selecionados como base para o planejando de atividades diversificadas. Nesse sentido, a literatura serve de ponte para incluir conteúdos de outras áreas como ciências, geografia, história, matemática, música, culinária e história da arte. A partir das histórias, professoras e alunos exploram, constroem, divertem-se, aprendem, ensinam, trocam, dramatizam, pintam, desenham juntos.

Expandindo um pouco para o uso do livro didático no Programa Bilíngue, acho importante esclarecer que, desde as primeiras reuniões para implantação do projeto, a diretora, a coordenadora geral, Ana e eu optamos por não adotar ou seguir nenhum material didático. Essa escolha tem sido mantida por acreditarmos que um único livro não seria suficientemente abrangente para englobar a diversidade dos conteúdos, podendo até limitar a criatividade e a autonomia do professor, em alguns casos. Acho relevante apontar que todo material didático utilizado em sala de aula é planejado, elaborado e criado pelas professoras para cada turma e, praticamente, renovado ou recriado a cada ano e que a Literatura Infantil é a base para o desenvolvimento das propostas de atividades para todas as turmas.

O fato de não termos material didático pronto nem para educação infantil nem para o ensino fundamental parece ser visto como sinônimo de muito trabalho para algumas colegas que, nos últimos anos, têm mencionado as possíveis vantagens da escola adotar um livro didático. Construir e renovar a cada ano focando no grupo, nos assuntos do cotidiano, nos interesses dos alunos, para mim e para algumas professoras, é de muita importância. A autonomia para elaborar e criar uma sequência de atividades e de produzir materiais novos com cada turma é primordial, na minha opinião. Até o presente momento, a coordenação mantém a decisão inicial de que o uso de um livro didático poderia limitar o trabalho do professor. 
Não intenciono, nesta dissertação, discorrer sobre como venho elaborando atividades e materiais em inglês para promover o ensino e a aprendizagem de conteúdos curriculares de ciências, história, geografia, artes e matemática com minhas turmas. Ressalto, contudo, que as atividades apresentadas ao longo da dissertação foram realizadas pelos alunos sem minha ajuda, sem dicionários ou outro tipo de consulta. A produção escrita de cada aluno corresponde à sua maturidade e ao seu grau de proficiência na língua inglesa. As Atividades Pedagógicas com Potencial Exploratório, apresentadas nos capítulos 5 e 6, não passaram por nenhuma correção ortográfica da minha parte por acreditar que cada aluno encontra-se em uma etapa em seu processo de construção da linguagem. A espontaneidade na escrita é estimulada não somente no Programa Bilíngue como também nos primeiros anos da escolarização nas turmas regulares, sendo uma prática estimulada na escola. É possível observar nas atividades a autonomia dos alunos em relação a apresentação visual na folha de papel, na qual cada aluno participante escreveu da forma que escolheu.

Além da Literatura Infantil, outros aspectos são fundamentais para o desenvolvimento do trabalho no contexto do Programa Bilíngue como a integração dos alunos, das turmas, da equipe e dos conteúdos; a interdisciplinaridade; a possibilidade de inventar e reinventar a cada ano letivo; a criatividade e a autonomia do professor. Para mim, esses aspectos motivaram minha entrada na escola e ainda, depois de 17 anos, motivam e até me encantam.

\section{3.}

\section{Eu: me formando professora}

Sempre respondi à pergunta 'o que você vai ser quando crescer?' dizendo que queria ser professora. Nas disciplinas estudadas na escola, tive excelentes professores de História e Biologia e posso dizer que me destaquei nessas áreas enquanto aluna e conseguia me imaginar fazendo o que meus professores faziam, tamanha era a admiração que sentia por eles.

Vasculhando minhas memórias, recordo-me que no ensino fundamental 1, na minha escola, ensinava-se francês. Somente aos onze anos, tive minha primeira aula de inglês. Revendo tudo com meu olhar atual, não sei como gostei daquelas aulas nas quais eu tinha que memorizar diálogos artificiais e sem sentido, além de 
preencher lacunas com o verbo to be. Inglês não fazia parte do contexto da minha família. Na época, eu somente tinha acesso à cultura de países de língua inglesa através de músicas que tocavam nas rádios e filmes no cinema. Contudo, fui aluna dedicada no estudo da língua.

Escolhi fazer o curso de Pedagogia e meu interesse maior era pelas disciplinas de Psicologia e Didática. Surgiu, então, a oportunidade de fazer um intercâmbio em um College em uma cidade perto da Filadélfia, nos Estados Unidos. Lá, cursei disciplinas em Education, English, Biology, Psychology e Art History. Sabia que queria ser professora, mas não tinha ideia do quê faria, do que iria ensinar pois me interessava por várias áreas. Ao retornar, fiz um treinamento e fui aprovada para dar aulas em um curso de Inglês, muito sério como instituição de trabalho, ao qual me dediquei bastante. Depois de quatro anos no curso, fui morar nos Estados Unidos por mais de dois anos e meio, primeiro em Los Angeles e depois em Denver. Tive a chance de cursar disciplinas na área de Literatura e de fazer cursos na UCLA e na University of Colorado.

Ao retornar, fui trabalhar no mesmo curso de inglês e comecei a sentir falta de espaço para criar porque o uso do material e da sequência prédeterminada já não faziam sentido para mim. Alguns anos se passaram até que cheguei à escola. Naquele momento, a Pedagogia e a Língua Inglesa começaram a fazer sentido juntas e me tornei realmente a professora que havia imaginado ser. Ou melhor, estou me tornando a professora que imaginei.

Nessa trajetória, tudo foi importante para minha formação, mas destaco aqui o curso o que fiz na Universidade do Colorado sobre alfabetização e letramento de crianças - Whole Language and Phonics - o qual despertou meu interesse para continuar lendo, estudando e pesquisando os assuntos abordados durante as aulas. Mais tarde, ao iniciar no Programa Bilíngue da escola, esse curso serviu de base em termos de literatura infantil e me ajudou na criação e elaboração de material didático específico para crianças.

Hoje, por causa das minhas vivências, defendo uma postura interdisciplinar na formação e profissionalização de professores de inglês para os anos iniciais, onde os departamentos e cursos de graduação em Letras e Pedagogia poderiam se unir com objetivo de embasar os professores interessados nesse segmento da escolarização.

À seguir, apresento os sete alunos participantes da pesquisa. 


\section{4. \\ Os alunos participantes}

No momento de construção da dissertação, existem nove turmas no Programa Bilíngue, distribuídas em dois contra-turnos, com 95 alunos matriculados. O grupo docente é formado por 8 professoras, sendo que apenas 3 atuam nos dois turnos; eu sou uma delas. As experiências e vivências profissionais do grupo são bastante variadas.

As turmas no Programa Bilíngue são formadas seguindo os seguintes critérios: primeiro, leva-se em consideração a idade das crianças e, segundo, o número de vagas em cada turma. As grupadas, assim chamadas na escola, são formadas com, no máximo, 12 alunos em cada. Nos anos iniciais, ou seja, na educação infantil, as professoras trabalham em duplas, sempre que possível. Já as professoras das grupadas do ensino fundamental contam com a ajuda de uma professora volante para suporte com o almoço, o qual faz parte da rotina das aulas. Na escola, a denominação 'volante' é usada para quem não é regente de turma.

Das minhas duas turmas, somente a do turno da tarde participou da pesquisa. A turma é formada por sete alunos, entre 10 e 11 anos de idade. Todos moram nos arredores da escola, sendo que Giovana, Theo, Breno, Gael e Bruna vão para escola à pé, Tito de bicicleta com a mãe e Daniel de transporte escolar. No turno da manhã, mais especificamente, de $7 \mathrm{~h} 30 \mathrm{~m}$ às $12 \mathrm{~h}$, estes alunos têm aulas regulares do currículo básico da língua materna, matriculados nos $4^{\circ}$ e $5^{\circ}$ anos do Ensino Fundamental. Das $12 \mathrm{~h}$ às $14 \mathrm{~h} 30 \mathrm{~m}$, de segunda a sexta-feira, são agrupados, formando a turma do Programa Bilíngue.

Aproveito para descrever brevemente a rotina dos alunos participantes. $\mathrm{Na}$ parte da manhã, as turmas do $4^{\circ}$ e $5^{\circ}$ ano convivem com uma professora regente, assistida pela professora volante, sempre que necessário. Para as aulas semanais de 40 minutos de duração, os alunos são encaminhados para outros espaços no ambiente escolar, como para as aulas de Educação Física, Biblioteca, Artes, Música, Laboratório de Ciências e Informática, permanecendo em suas salas para as aulas de Inglês. Ao término da aula regular, ao meio-dia, dirigem-se à nossa sala. Nos 15/20 minutos iniciais, escolhem onde sentar, organizam seus materiais, terminam alguma atividade do dia anterior e preparam-se para o almoço. No 
refeitório são recebidos pela professora Tânia (nome fictício). O almoço, preparado na cozinha e servido no refeitório, é entendido, por nós professoras, como uma atividade pedagógica e um momento de interação. Ao retornar para nossa sala, os alunos escovam os dentes e brincam no pátio. Às $13 \mathrm{~h}$, retomamos as atividades dirigidas, que são realizadas na sala de aula ou no pátio. Todas as atividades dirigidas são realizadas em inglês e envolvem leitura, escrita e compreensão, com maior ênfase na oralidade.

Acho importante ressaltar que troquei os nomes dos alunos participantes para proteger suas identidades, porém mantive as idades e ano escolar de cada um. Ao longo da dissertação, escolhi usar a ordem dos nomes como apresentados a seguir.

\section{Quadro 1 - Os alunos participantes}

\begin{tabular}{|c|c|c|}
\hline Alunos & $\begin{array}{c}\text { Idade em } \\
2019\end{array}$ & $\begin{array}{c}\text { Ensino } \\
\text { Fundamental }\end{array}$ \\
\hline Giovana & 11 anos & $5^{\circ}$ ano \\
\hline Theo & 11 anos & $5^{\circ}$ ano \\
\hline Tito & 10 anos & $4^{\circ}$ ano \\
\hline Breno & 10 anos & $4^{\circ}$ ano \\
\hline Daniel & 10 anos & $4^{\circ}$ ano \\
\hline Gael & 10 anos & $4^{\circ}$ ano \\
\hline Bruna & 10 anos & $4^{\circ}$ ano \\
\hline
\end{tabular}

Após a apresentação inicial dos sete alunos participantes e da cultura social e histórica da escola, acho necessário explicar minha intenção de construir a dissertação propondo a colaboração e inclusão das crianças como participantes ativos, como agentes da pesquisa. A agentividade (GIEVE; MILLER, 2006) no processo de pesquisa do praticante caracteriza-se por ser inclusiva ao envolver todos em buscas por entendimentos das questões relevantes para o grupo.

Pinter $(2014,2017)$ sugere a participação das crianças em pesquisas na área de Linguística Aplicada e aponta para a necessidade de ouvir a criança, de entender o que é importante para ela. A autora usa a metáfora da escada de participação (cf. participation ladder) para se referir aos diferentes modos de participação da criança em pesquisas, ou seja, como objeto de pesquisa, como sujeito da pesquisa, como ator social e como copesquisador. No primeiro, a criança é excluída das etapas de construção, é tratada como sujeito passivo, 
pesquisado e interpretado pelo adulto. No segundo, tanto em estudos qualitativos quanto quantitativos são os pesquisadores adultos que analisam, interpretam, tomam decisões, fazem escolhas e reportam a voz da criança, prevalecendo o ponto de vista do adulto. No terceiro modo, a criança tem a mesma importância que o adulto, participa e colabora ativamente na pesquisa, e tem seus direitos respeitados. O quarto modo, que seria o topo da escada na metáfora, é uma extensão do terceiro. A criança é envolvida, informada e consultada nas etapas da pesquisa e, como copesquisadora, divide responsabilidades com o adulto.

Considero pertinente mencionar que fazer pesquisa com crianças envolve um olhar atento e uma escuta sensível, assim como, um respeito ao momento em que se encontram em seu desenvolvimento físico e cognitivo. Desse modo, como professora-pesquisadora-praticante, propus a participação dos sete alunos com a intenção de, junto com eles, buscar maiores entendimentos acerca do contexto pedagógico do Programa Bilíngue, no qual convivemos diariamente. Foi nesse ambiente que os dados apresentados na pesquisa foram gerados.

\section{5. \\ Minha motivação inicial}

Ao chegar em nossa sala ao meio-dia, depois de ter passado por várias aulas e atividades desde às $7 \mathrm{~h} 30$, os alunos faziam comentários e queixas a respeito de outros professores da escola, narrando as experiências do dia. Minha postura era orientar para que conversassem com os professores, pois eu não podia ajudar nem resolver as questões por eles trazidas. A recorrência das narrativas despertou em mim uma vontade de compreender como os alunos entendiam o professor, ou melhor, como o professor era visto por eles. Partiu de mim a intenção de investigar e daí surgiu a primeira Atividade Pedagógica com Potencial Exploratório. Essa atividade desencadeou muitas outras. Uma das selecionadas para compor o conjunto de dados foi a que me refiro como segunda Atividade Pedagógica com Potencial Exploratório, na qual os alunos escreveram seis perguntas para entrevistar um professor de inglês. Conforme já mencionado, uma atividade foi levando à outra e planejei, então, a atividade que considero como terceira, na dissertação. Na terceira Atividade Pedagógica com Potencial Exploratório, minha intenção era focar em suas percepções e entendimentos acerca do lugar-escola, na qual os alunos se expressaram por textos e desenhos. 
Apesar da assinatura dos termos e das nossas conversas sobre a pesquisa na sala de aula, as três Atividades Pedagógicas com Potencial Exploratório foram realizadas sem que os alunos se dessem conta de que as mesmas seriam usadas na dissertação por dois motivos. Primeiro, tenho a impressão que os alunos identificaram as atividades como de rotina e, segundo, achei que o fato de não chamar a atenção para a pesquisa daria um tom mais espontâneo à participação de cada aluno. Já as conversas gravadas em áudio foram entendidas por eles com um certo estranhamento por não fazerem parte da rotina de nossa prática pedagógica e, portanto, encaradas de forma diferente. Acho que foi no momento das gravações que os alunos participantes entenderam que estavam colaborando com a pesquisa. Isso posto, na próxima seção, explico com mais detalhes o conjunto de dados que integram a pesquisa.

\section{6. \\ Geração dos dados, transcrição e análise}

Meu convívio diário com os sete alunos participantes possibilitou a geração de um conjunto de dados que engloba as Atividades Pedagógicas com Potencial Exploratório realizadas por eles, as gravações em áudio de conversas individuais entre os alunos e eu, e as anotações de comentários feitos pelos alunos espontaneamente. Para compor este conjunto, também incluí as anotações e as observações realizadas durante conversas com a direção e coordenação, os registros feitos durante reuniões pedagógicas, as consultas ao endereço eletrônico e ao Projeto Político Pedagógico do Programa Bilíngue.

Em relação às Atividades Pedagógicas com Potencial Exploratório optei por apresentar três atividades realizadas no horário escolar. A primeira se relaciona a figura de um bom professor de inglês, a qual surgiu a partir de conversas entre os alunos sobre professores bons e não tão bons. A segunda, propus aos alunos que preparassem uma entrevista para contratar um novo professor para o Programa Bilíngue com a intenção de buscar maiores entendimentos sobre a figura do professor de inglês nos primeiros anos de escolarização. A terceira, envolve a relação dos alunos com o lugar-escola, o qual foi retratado através de desenhos e textos escritos. 
As conversas individuais com os sete alunos participantes foram gravadas em áudio com um aparelho de celular e, por mim, transcritas. Estou ciente que nenhuma transcrição é neutra uma vez que o pesquisador escolhe as categorias descritivas que serão empregadas e à disposição no meio escrito. Biar (2012, p. 67) se referindo à transcrição dos dados em sua tese, aponta que

[...] como em todas as etapas da pesquisa, se impõe um processo seletivo guiado pelos olhos do pesquisador que, diante da impossibilidade de dar conta da complexidade da situação de interação e da impossibilidade de manter-se neutro e em condição de observador distanciado, desde então interpreta a situação social, muitas vezes de que fez parte [...]

Alinho-me com a autora por entender que sou parte das conversas exploratórias com os alunos, das transcrições e das interpretações que realizo ao longo da dissertação. Outro aspecto relevante é que uma conversa envolve tantos detalhes que não se consegue captar em uma transcrição. Nesse sentido, as transcrições que apresento nessa dissertação já fazem parte da análise e de minha interpretação do evento conversa exploratória.

Nas transcrições, empreguei as convenções adaptadas da Análise da Conversa sugeridas por Bastos e Biar (2015), conforme tabela (na página 11 desta dissertação). Ao transcrever, considerei aspectos paralinguísticos como alongamento de vogal, pausas, entonação, falas mais rápidas e mais lentas. Os excertos selecionados e apresentados no capítulo 7 referem-se aos temas das Atividades Pedagógicas com Potencial Exploratório e ao entendimento de cada aluno acerca de sua participação na pesquisa.

Ao situar esta dissertação no campo da Linguística Aplicada, entendo que a mesma dialoga com a Linguística Sistêmico-Funcional no âmbito do ensino e da aprendizagem da língua inglesa (VIAN JR., 2013, p. 137-141). Tanto a Linguística Aplicada quanto a Linguística Sistêmico-Funcional unem e atravessam disciplinas, visando criar entendimentos inter/transdisciplinares. Dessa forma, para analisar discursivamente as transcrições das interações gravadas em áudio, pretendo focar na avaliação realizada pelos alunos participantes. Cada escolha avaliativa feita pelos alunos é permeada por outros discursos, por suas crenças e seus julgamentos como crianças de 10 e 11 anos, por suas experiências e vivências sociais na escola, na família, no mundo, e pelo afeto. 
O Sistema de Avaliatividade (MARTIN; WHITE, 2005; WHITE, 2004; NÓBREGA, 2009) é um pilar teórico, por mim escolhido, para avaliar as avaliações realizadas pelos sete alunos durante nossas conversas exploratórias. O Sistema de Avaliatividade, inserido no referencial teórico da Linguística Sistêmico-Funcional será melhor detalhado no próximo capítulo.

Assim, recapitulando, em todas as etapas da pesquisa - nas conversas gravadas, nas transcrições, na seleção dos excertos e na análise - esclareço que minhas escolhas foram guiadas pelo meu olhar de professora-pesquisadorapraticante. Com foco na avaliação, recorro ao Sistema de Avaliatividade para a microanálise do discurso, o que contribui para o enriquecimento da pesquisa do praticante e para promoção de uma maior conscientização dos praticantes com relação às práticas discursivas.

Antes de seguir, acho importante sintetizar que neste capítulo apresentei o contexto sócio-histórico e situacional da escola e dos participantes da pesquisa; mencionei as afinidades teórico-metodológicas que embasarão a análise dos dados apresentados na dissertação; introduzi a noção de pesquisa do praticante; e justifiquei a participação das crianças. No próximo capítulo, enfoco no aporte teórico, ao qual busco alinhamento para tecer reflexões e analisar os dados gerados na pesquisa. 


\section{Aporte teórico para análise dos dados}

Este capítulo divide-se em três subseções, as quais formam a base teórica para dar suporte à análise dos dados gerados na pesquisa. Primeiro, proponho uma reflexão sobre as (pre)disposições pessoais e profissionais do professor; segundo, discorro sobre crenças e emoções na educação; e terceiro, apresento o Sistema de Avaliatividade com foco na avaliação como aporte teórico para análise textual dos dados gerados nas conversas gravadas em áudio.

\section{1.}

\section{(Pre)disposições pessoais e profissionais do professor}

$\mathrm{Na}$ busca de melhor entender os aspectos que circundam a formação pedagógica, a formação linguística e a formação profissional global do professor de inglês, busco relacionar as cinco (pre)disposições sugeridas por Nóvoa (2009) com a formação e a profissionalização das professoras no contexto do Programa Bilíngue da escola. O autor citado justifica o uso do termo (pre)disposição em lugar de competência, explicando que o segundo "nunca conseguiu libertar-se das suas origens comportamentalistas e de leituras de cariz técnico e instrumental" (ibidem, p. 3). As cinco (pre)disposições propostas pelo autor são: o conhecimento, a cultura profissional, o tato pedagógico, o trabalho em equipe e o compromisso social, as quais são construídas ao longo da formação docente dentro e fora do ambiente de trabalho. Antes de discorrer sobre cada uma, esclareço que no capítulo 5 retornarei às (pre)disposições ao analisar as atividades dos alunos participantes sobre o professor de inglês.

\subsection{1. O conhecimento}

Ao afirmar que "ninguém pensa no vazio", Nóvoa (ibidem) destaca a importância, para o professor, de conhecer bem o que ensina para, então, construir práticas que levem os alunos à aprendizagem. Para o autor, a escola educa através do conhecimento, portanto, não há educação sem conhecimento.

Acredito que o conhecimento é (co-) (re-) (des-) construído ao longo da vida dentro e fora da escola. Dessa forma, o professor não deve ser visto como o 
único que tem o conhecimento e que é capaz de depositá-lo nos alunos. Uma de suas funções é "construir andaimes" para o aluno aprender e converter o conhecimento externo em seu próprio conhecimento (BRUNER, 1985 apud MOITA LOPES, 1996, p. 97). Para construir os andaimes, na minha visão, o professor deve conhecer o que ensina.

Opto por concentrar minha atenção no professor de inglês que atua nos anos iniciais de escolarização, mais especificamente, os que trabalham no contexto do Programa Bilíngue. Neste recorte, o conhecimento da língua inglesa é prioridade e envolve os saberes linguísticos, a oralidade, a escrita, a compreensão, a leitura, assim como vivências culturais compartilhadas no ambiente educacional. Acho que tanto o conhecimento linguístico quanto o conhecimento pedagógico fazem ou deveriam fazer parte da formação do professor de inglês que atua nos anos iniciais. O conhecimento pedagógico é aquele que se refere a saberes vinculados às ciências da educação e inclui a didática, a ética e as dimensões sócio-afetivas, e abrange o diálogo entre as teorias de ensino e as práticas de sala de aula. Entendo que no Programa Bilíngue da escola ambos - o conhecimento da língua e das práticas pedagógicas - são tratados com a mesma importância.

Nesta reflexão acerca do conhecimento, considero pertinente apontar para a importância da formação e profissionalização tanto linguística quanto pedagógica do professor de inglês que trabalha na educação infantil e no ensino fundamental 1, por entender que cabe ao professor a construção de práticas docentes a fim de criar oportunidades de aprendizagem para os alunos em seus processos de construção da língua.

\subsection{2.}

\section{A cultura profissional}

Segundo Nóvoa (ibidem), a cultura profissional é o conhecimento construído da/na instituição de trabalho, "no diálogo" e no contato "com os colegas mais experientes". O autor defende a ideia de que a formação do professor deve passar para dentro da escola, onde os professores mais experientes teriam papel central na formação dos mais jovens e aponta, em uma entrevista para uma revista que (NÓVOA, 2001, s/p), 
o desenvolvimento pessoal e profissional depende muito do contexto em que exercemos nossa atividade. Todo professor deve ver a escola não somente como o lugar onde ele ensina, mas onde aprende. A atualização e a produção de novas práticas de ensino só surgem de uma reflexão partilhada entre os colegas.

Dessa forma, a cultura profissional envolve: (i) as relações interpessoais que se estabelecem no ambiente escolar; (ii) o diálogo e a colaboração entre os professores; (iii) as reflexões sobre a prática; (iv) a busca por maiores entendimentos locais. Ecoando essa visão, a busca por entendimentos mais profundos ao invés de soluções é prioridade na Prática Exploratória (ALLWRIGHT; HANKS, 2009). Essa busca é um processo contínuo e envolve refletir e fazer. Refletir sobre a prática, pensar e repensar de modo mais profundo sobre dúvidas, curiosidades, sentimentos, experiências, dificuldades que surgem na sala de aula. Fazer é a ação pedagógica na sala de aula. Assim, refletir e fazer relacionam-se à possibilidade de olhar com profundidade para uma questão e buscar entendimentos locais, provisórios, que pertencem àquele momento, àquele contexto, àquela escola, sem a intenção de encontrar respostas definitivas ou propor soluções generalizáveis.

Dessa forma, entendo a cultura profissional como cultura local, de um grupo, de uma escola que reflete sua prática pedagógica em conjunto, a qual vivencio desde o início no Programa Bilíngue. Assim como aprendo como os colegas também tenho oportunidades de ensinar e dividir com eles meus conhecimentos e entendimentos.

\subsection{3. \\ O tato pedagógico}

De acordo com Nóvoa (ibidem), no conceito de tato pedagógico cabe a "capacidade de relação e de comunicação sem a qual não se cumpre o ato de educar". Na prática docente, as capacidades de se relacionar e de se comunicar com o outro encontram-se interligadas. Dessa maneira, o tato pedagógico não limita o professor ao aspecto profissional, isto é, ser capaz de conduzir o aluno na construção de suas aprendizagens. O tato pedagógico envolve um aspecto pessoal que diz respeito ao afeto, às emoções, à ética. No meu contexto de trabalho, o professor de inglês interage com o grupo de alunos, com o aluno individualmente, com outros professores, assim como, coordenadores pedagógicos, supervisores, 
diretores, administradores, e outros funcionários da escola. Nessas interações diárias, o professor exerce suas capacidades de se relacionar e se comunicar.

O tato pedagógico refere-se também à capacidade que o professor possuí de "tecer uma complexa rede de conexões entre eles mesmos, suas matérias e seus alunos, de forma que esses últimos possam aprender a tecer um mundo para si próprios" (PALMER, 2012, p. 27). "Tecer conexões" abrange: se conhecer autoconhecimento; construir conhecimentos sobre o que ensina - se profissionalizar; e estar disposto a olhar para o outro - empatia. Nesse sentido, o tato pedagógico pode ser entendido como um modo de ser e de estar presente na sala de aula e na escola, uma forma de olhar com atenção o outro, uma atitude mais reflexiva sobre a prática diária, um cuidado ao falar, uma sensibilidade para ouvir. É o que vivencio diariamente, como praticante exploratória, no contexto do Programa Bilíngue.

\subsection{4. \\ 0 trabalho em equipe}

O trabalho em equipe incluí a dimensão coletiva e colaborativa do trabalho docente. Nóvoa (1992, p. 26) menciona a importância dos professores se envolverem em trabalhos interativos, em reflexões coletivas, onde

[...] a troca de experiências e a partilha de saberes consolidam espaços de formação mútua, nos quais cada professor é chamado a desempenhar, simultaneamente, o papel de formador e de formando. $\mathrm{O}$ diálogo entre os professores é fundamental para consolidar saberes emergentes da prática profissional.

Entendo o trabalho em equipe como parcerias entre os professores. Esse tipo de trabalho não se limita à exposição de atividades coletivas em murais, ou organização de festas e eventos escolares, ou mesmos reuniões. Ou melhor, vai além disso; é um trabalho coletivo e colaborativo. Em muitas escolas, por exemplo, o professor de inglês a partir do $6^{\circ}$ ano vivencia a fragmentação das disciplinas, o que impõe isolamento por questões de horário e, algumas vezes, por falta de incentivos, dificultando, dessa forma, a integração no ambiente escolar. Por essa razão, há necessidade de organizar-se em grupos no contexto escolar. A 
colaboração entre docentes é vivenciada em uma relação de ajuda, apoio, troca e diálogo.

Nessa mesma linha de pensamento, Fullan e Hargreaves (2001) enfatizam que a colaboração ocorre a partir do ensino em equipe, da partilha na tomada de decisões e da responsabilidade coletiva como princípio articulador e integrador das ações e do planejamento. Para Hargreaves (1998, p. 209), "a colaboração e a colegialidade são consideradas pontes vitais entre o desenvolvimento das escolas e dos professores". O trabalho em equipe é uma maneira de colaborar com os colegas e de criar interdependências, o que permite partilhar responsabilidades, trabalhar para o aperfeiçoamento individual e coletivo, refletir sobre as atividades e tarefas diárias, assim como buscar entendimentos locais.

Corroborando essa concepção de trabalho em equipe, Allwright (2001, p. 117), referindo-se ao fato de os professores estarem "sempre ocupados e nunca terem tempo para sentar e pensar/refletir juntos sobre seus trabalhos e seus entendimentos a respeito do trabalho", aponta que "não podemos ir muito longe se estivermos sozinhos" [...] e que devemos "estar com outras pessoas para ver se podemos entender coletivamente o que nos escapa individualmente". Na minha leitura, Allwright e Nóvoa compartilham a mesma ideia acerca do trabalho em equipe.

Acredito que o trabalho em equipe pode fortalecer o grupo de professoras do Programa Bilíngue, mesmo levando em consideração a tendência das mesmas de se agrupar em educação infantil e ensino fundamental.

\subsection{5. \\ O compromisso social}

O compromisso social, para Nóvoa (ibidem), abrange os princípios, os valores, a inclusão social e a diversidade cultural. Compromisso social, como eu entendo, é a postura do professor dentro e fora do espaço escolar. O compromisso social está relacionado à ética profissional e envolve posicionamentos, reflexões, ações, responsabilidades individuais e coletivas. Envolve, também, a coerência entre o falar e o fazer dentro e fora da escola.

$\mathrm{Na}$ visão do autor, a profissão não está circunscrita ao espaço físico da escola. Ser professor ultrapassa os muros da escola e avança para o espaço 
público, o que acentua o papel social dos professores. A este respeito, acho pertinente lembrar os três pilares da escola - conhecimento, cultura e valores previamente citados no terceiro capítulo. Os pilares encontram-se vinculados ao compromisso social e educacional dos professores, dos coordenadores e das diretoras da escola.

Após considerar os cinco aspectos que envolvem as dimensões pessoais e profissionais no contexto do professor de inglês, acho pertinente refletir sobre essa linha que separa a dimensão pessoal ou "pessoalidade do professor" da dimensão profissional ou "profissionalidade docente". Essa linha existe ou não?

Para Nóvoa (ibidem), "no ensino, as dimensões profissionais cruzam-se sempre, inevitavelmente, com as dimensões pessoais”. Consonante à essa visão, Gieve e Miller (2006, p. 19) consideram que "nossas vidas pessoais e profissionais estão interligadas". Enquanto Palmer (2012, p. 33) aponta que "o magistério é um exercício diário de vulnerabilidade" e "sempre ocorre em uma perigosa junção da vida pessoal com a vida pública". Os autores citados parecem compartilhar a ideia de que o professor não é um professor-pessoa e um professorprofissional, mas sim um indivíduo que convive com as duas dimensões todo o tempo. Segundo Nóvoa (2001- entrevista s/p.),

\begin{abstract}
a preocupação com a pessoa do professor é central na reflexão educacional e pedagógica. Sabemos que a formação depende do trabalho de cada um. Sabemos também que mais importante do que formar é formar-se; que todo o conhecimento é autoconhecimento e que toda a formação é autoformação. Por isso, a prática pedagógica inclui o indivíduo, com suas singularidades e afetos.
\end{abstract}

Em afinidade com este pensamento, entendo que as duas dimensões são partes que integram o indivíduo de forma singular. Não há dois indivíduos iguais. Não há dois professores iguais. "Cada um tem o seu modo próprio de organizar as aulas, de se movimentar na sala, de se dirigir aos alunos, de utilizar os meios pedagógicos, um modo que constitui uma espécie de segunda pele profissional" (NÓVOA, 2013, p. 16). Mesmo sem percebê-lo, o professor de inglês mais especificamente, no Programa Bilíngue, traz para sala de aula sua infância, sua vivência como aluno, sua formação básica, suas interações com bons e não tão bons professores, seu gosto ou não pelas matérias fragmentadas, seus aprendizados e conquistas, sucessos e insucessos, sua formação universitária especializada, seu histórico escolar, suas primeiras experiências profissionais, 
suas preferências metodológicas, sua pedagogia única e singular, sua paixão pela linguagem verbal e escrita. Tudo isso somado a suas características individuais como timidez, criatividade, extroversão, atenção, habilidades manuais, musicais e artísticas, seus afetos e emoções. Assim, o professor traz para sala de aula as dimensões pessoais e profissionais entrelaçadas. E "é impossível separar o eu profissional do eu pessoal" (ibidem, p. 17).

\section{2. \\ Crenças e emoções}

O termo crença relaciona-se à convicção de que algo é verdadeiro e baseia-se em avaliações pessoais e subjetivas advindas de experiências anteriores. Conceituar crenças parece complexo e pode variar de cultura para cultura. Barcelos (2006, p. 18; 2007, p. 113) aborda crenças como "sociais (mas também individuais), dinâmicas, contextuais e paradoxais". Conforme a autora, crenças são dinâmicas e portanto não estáticas ou seja, podem mudar com o tempo em diferentes contextos. É interessante que também são consideradas paradoxais por serem, ao mesmo tempo, individuais e sociais; diversas e uniformes.

Apesar de saber que o tema crenças em relação ao ensino e aprendizagem de línguas vem sendo estudado e definido por vários autores, optei pela definição de Barcelos (2001, p. 72) ao afirmar que crenças são "opiniões e ideias que alunos (e professores) têm a respeito dos processos do ensino e aprendizagem de línguas". Não tenho como objetivo generalizar, mas sim buscar compreender as crenças construídas pelos alunos no contexto do Programa Bilíngue. Sei que as crenças dos sete alunos participantes são influenciadas pelos familiares e pelos professores e por suas experiências e vivências individuais em um contexto sóciohistórico-cultural.

As crenças são construções da realidade que partem das experiências individuais e coletivas de cada pessoa. Para Barcelos (2004, p. 132), crenças "não são somente um conceito cognitivo, mas também social, porque nascem de nossas experiências e problemas, de nossa interação com o contexto e nossa capacidade de refletir e pensar sobre o que nos cerca". A autora destaca a relevância do contexto situado e localizado. Desse modo, um estudo deve buscar entender a interdependência e a interconexão entre crenças e contexto. Ainda segundo a 
autora, uma pesquisa a respeito das crenças dos alunos deve levar em conta suas experiências e ações; suas interpretações acerca das experiências; o contexto social; e "como os alunos usam suas crenças para lidar com a tarefa complexa de aprender línguas" (ibidem, p. 148). Faz-se necessário reconhecer professores e alunos como seres reflexivos no ambiente educacional e cultural da sala de aula e entender que suas crenças são construções interligadas ao contexto. Em outras palavras, as crenças dos sete alunos participantes são moldadas pelo contexto em que vivem.

Barcelos (2006, p. 19) discorre que as crenças "não estão dentro de nossas mentes como uma estrutura mental pronta e fixa, mas mudam e se desenvolvem a medida que interagimos e modificamos nossas experiências e somos ao mesmo tempo modificados por elas". A esse respeito, as crenças reveladas pelos alunos participantes fazem sentido no contexto sócio-histórico-cultural, no qual estão inseridos, levando-se em consideração a escolaridade e idade de cada aluno. Desse modo, as crenças dos alunos participantes são influenciadas pela família, colegas e mídia, pelo material didático, e pelas experiências pregressas com o idioma. Entendo que suas crenças são passíveis de mudanças à medida que interagem com o mundo e se constroem em experiências individuais e coletivas por eles vivenciadas. Segundo Barcelos (2013), a compreensão sobre as crenças dos alunos pode nos ajudar a entender motivações, estratégias e expectativas da aprendizagem de línguas. Para a autora (BARCELOS, 2001, p. 73),

As crenças influenciam como as pessoas organizam e definem suas tarefas. Em outras palavras, elas são fortes indicadores de como as pessoas agem. $\mathrm{Na}$ literatura em LA [Linguística Aplicada], a relação entre crenças e ações refere-se à maneira como as crenças podem influenciar a abordagem dos alunos em relação à aprendizagem.

Nessa perspectiva, as crenças podem afetar o comportamento dos alunos em relação ao ensino e à aprendizagem assim como suas atitudes nas interações em sala de aula, nos relacionamentos entre professor/aluno e aluno/aluno e nas questões afetivas que permeiam o contexto sócio-histórico-cultural. Conforme mencionado por Aragão (2019, p. 253), crenças sobre o ensino e a aprendizagem da língua inglesa como "falar igual a um falante nativo" e "aprender inglês é "lá fora' e nunca na escola" expressam o pensamento compartilhado por muitos, inclusive pelos alunos participantes, como veremos no capítulo 7. 
Barcelos (2019, p. 54) menciona em seu estudo três pesquisas nas quais os alunos esperam que os professores "os conduzam [...] de forma gentil, suave, amorosa, com respeito e com cuidado, [...] que tenham paciência com eles; que sejam apoio moral e emocional; que os ouçam". Embora o estudo da autora citada não inclua crianças, chamou minha atenção o fato de Gael, aluno participante, haver expressado os mesmos desejos ao refletir acerca da atividade $A$ good English teacher, detalhada no capítulo 5. O excerto a seguir pode ilustrar o tema discutido pela autora citada.

\section{Excerto - Gael - "é bom que ela acolhe o aluno"}

\begin{tabular}{|c|c|c|}
\hline $\begin{array}{l}77 \\
78 \\
\end{array}$ & Gael & $\begin{array}{l}\text { é e eu é: : eu escrevi é: a caractric- pra } \\
\text { uma professora ser boa em inglês }\end{array}$ \\
\hline 79 & Mara & aham \\
\hline $\begin{array}{l}80 \\
81\end{array}$ & Gael & $\begin{array}{l}\text { ela tem que: ser inteligente é: tem que: se } \\
\text { mover <devagar>, falar baix= }\end{array}$ \\
\hline $\begin{array}{l}82 \\
83\end{array}$ & Mara & $\begin{array}{l}\text { [mas o que é isso se mover } \\
\text { devagar como assim se mover devagar? }\end{array}$ \\
\hline $\begin{array}{l}84 \\
85\end{array}$ & Gael & $\begin{array}{l}\text { é: tipo é ela algumas professoras elas podem } \\
\text { tipo são muito agitadas }\end{array}$ \\
\hline 86 & Mara & {$\left[{ }^{\circ}\right.$ ah entendi $\left.{ }^{\circ}\right]$} \\
\hline 87 & Gael & [ficam: : \\
\hline 88 & Mara & [apressando?] \\
\hline $\begin{array}{l}89 \\
90 \\
91\end{array}$ & Gael & $\begin{array}{l}\text { é: apressando a gente então eu gosto das } \\
\text { professoras que são mais lentas que: esperam } \\
\text { os outros pra passar as atividades }\end{array}$ \\
\hline 92 & Mara & ${ }^{\circ}$ entendi ${ }^{\circ}$ mais alguma característica que vo= \\
\hline $\begin{array}{l}93 \\
94 \\
95 \\
96 \\
97 \\
98 \\
99 \\
100\end{array}$ & Gael & $\begin{array}{l}\text { sim tem que falar baixo não ficar gritando } \\
\text { que é chato ter uma pessoa toda hora } \\
\text { gritando no seu ouvido é:: elas têm que } \\
\text { cuidar dos-dos alunos >tipo< quando o aluno } \\
\text { se machuca ela não tem que chegar e falar é } \\
\text { "tanto faz" "cuida-cuida de vo-você, se } \\
\text { cuida sozinho" }\end{array}$ \\
\hline 101 & Mara & humhum \\
\hline $\begin{array}{l}102 \\
103 \\
104\end{array}$ & Gael & $\begin{array}{l}\text { é bom que ela acolhe o aluno, cuida do aluno } \\
\text { pega é: vai com o aluno até a sala do } \\
\text { coordenador que tem remédiô é isso }\end{array}$ \\
\hline 105 & Mara & ${ }^{\circ}$ entendi ${ }^{\circ}$ \\
\hline
\end{tabular}

Nesse fragmento é possível observar as crenças construídas por Gael em relação à professora de inglês, as quais poderiam também ser estendidas a outros professores da escola. $\mathrm{O}$ aluno esclarece que uma boa professora de inglês tem que ser inteligente, se mover devagar/esperar os outros para passar as atividades, falar baixo/não gritar, cuidar dos alunos, e acolher os alunos. 
Destaco que as escolhas realizadas por Gael parecem indicar que o mesmo fala do professor com propriedade, revelado no uso de "tem que" (linhas 80, 94, 96 e 98). Na minha interpretação, a professora de inglês 'tem que' pode significar que ela tem obrigação de ser ou fazer algo ou pode significar uma expectativa, ou seja, algo que Gael espera que aconteça em seu contexto escolar. Ao elencar as características da professora de inglês, o aluno começa por "inteligente" (linha 80), o que, para mim, se refere mais à formação profissional, tanto linguística quanto pedagógica. As características seguintes mencionadas por Gael parecem estar relacionadas às "competências sócio-emocionais" e ao "conceito de amorosidade" (BARCELOS, 2019, p. 47), sendo que a amorosidade está "pautada em princípios éticos de exigência e de seriedade" e trata-se de um conceito que Freire ([1996] 2018a), o qual relaciona-se à generosidade, humildade e esperança.

Crenças e emoções não podem ser separadas conforme sugere Barcelos (2010, p. 177) ao destacar que "emoções moldam crenças intensificando-as, tornando-as mais fortes ou fracas, criando crenças e alterando-as; essas crenças por sua vez, moldam as emoções que sentimos”. Do ponto de vista biológico, emoções são "disposições corporais dinâmicas que definem os diferentes domínios de ação em que nos movemos" (MATURANA, 2002, p. 15). Etimologicamente, a palavra emoção, de origem do latim, significa 'mover para fora'. Essa noção de movimento parece relevante quando consideramos as relações humanas no contexto pedagógico, onde a convivência social implica em movimentos como: o domínio de certas emoções; o autocontrole para manter o equilíbrio; e a reflexão acerca de nossas respostas emocionais. No ambiente escolar, as interações são diárias, intensas e muitas vezes confusas. A sala de aula, por exemplo, pode ser entendida como lugar de oportunidades, cuidados, acolhimento, alegria, respeito e confiança. Mas, a mesma pode ser lugar de medos, tristeza, apatia, indiferença, raiva, omissão e vergonha. A sala de aula é lugar de aprendizagens, onde as interações entre professores e alunos envolvem emoções, que são experienciadas e expressadas (ou não) de acordo com a individualidade e bagagem cultural de cada um.

O conceito de amorosidade, já mencionado, nos remete ao amor. "O amor é a emoção que constitui o domínio de ações em que nossas interações recorrentes com o outro fazem do outro um legítimo outro na convivência" (MATURANA, ibidem, p. 22). 'Fazer do outro um legítimo outro' envolve empatia, ou seja, a 
capacidade de se colocar no lugar do outro, de ajudar o outro, de tentar compreender emocionalmente o outro. A sala de aula é um lugar onde as histórias de vida se entrelaçam em um convívio que pode tocar, inquietar, marcar tanto os professores quanto os alunos. 'Fazer do outro um legítimo outro na convivência' envolve ética, tolerância, escuta atenta, compromisso, cuidados e acolhimento.

Nesse sentido, acho que um olhar sobre as crenças e as emoções no discurso dos sete alunos participantes pode contribuir para melhor entender o contexto no qual estão inseridos. Conforme Barcelos (2004, p. 145), "nós precisamos aprender a trabalhar com crenças em sala, já que ter consciência sobre nossas crenças e ser capaz de falar sobre elas é um primeiro passo para professores e alunos reflexivos". Faremos isso no capítulo 7. A seguir, nas próximas seções, discorro sobre o Sistema de Avaliatividade, que balizará as análises do discurso dos alunos participantes.

4.3.

A Avaliação a partir da abordagem sistêmico-funcional

Segundo Nóbrega e Abreu (2019, no prelo), baseadas em Thompson e Hunston (2000, p. 6),

a avaliação possui, simultaneamente, as seguintes funções: (i) expressar as opiniões de falantes e de escritores, proporcionado o entendimento do sistema de valores do falante (ou escritor) e de sua comunidade; (ii) construir e manter relações entre falante e ouvinte (ou escritor e leitor) e (iii) organizar o discurso.

Considerando as três funções acima, o contexto tem papel fundamental na análise das avaliações construídas pelos alunos participantes acerca das crenças e emoções relacionadas ao ambiente escolar por eles vivenciados. Neste viés, "os significados avaliativos são criados no discurso durante as interações sociais, de acordo com aspectos contextuais específicos a cada interação" (ABREU; NÓBREGA, 2015, p. 289). As conversas exploratórias entre os alunos e eu mostram a linguagem em uso, em um contexto situado. Dessa forma, "a linguagem oferece mecanismos diversos para que atribuamos diferentes avaliações aos mais diferentes aspectos de nossas atitudes em nosso cotidiano" (VIAN JR., 2010, p. 19). As avaliações podem ser realizadas de forma implícita 
ou explícita e encontram-se associadas ao texto, enquanto a avaliatividade está associada à semântica do discurso.

Como mencionado, no capítulo 3, pretendo usar o Sistema de Avaliatividade (MARTIN, 2003; MARTIN; WHITE, 2005) como aporte teóricoanalítico para análise das avaliações presentes nas conversas exploratórias entre os sete alunos participantes e eu. Segundo Nóbrega (2009, p. 78), o Sistema de Avaliatividade "se baseia em aspectos sociais e funcionais para conduzir investigações acerca da prática avaliativa”. O Sistema de Avaliatividade está inscrito no arcabouço teórico da Linguística Sistêmico-Funcional (HALLIDAY, 1994), a qual foi desenvolvida inicialmente na década de 1980 em trabalhos no campo da linguística educacional, na Austrália, mais especificamente, em programas de letramento baseados em gêneros textuais.

Sendo uma área, ao mesmo tempo, da e na Linguística Aplicada, a Linguística Sistêmico-Funcional pode ser considerada tanto uma teoria social e semiótica quanto uma gramática funcional com base em investigações linguísticas no campo social. Assim como a Linguística Aplicada, a Linguística SistêmicoFuncional atravessa diferentes áreas e caracteriza-se por seu viés interdisciplinar (VIAN JR., 2013). Como teoria social, parte da sociedade e das situações de uso da língua para o estudo da linguagem, oferecendo ferramental para compreender como o significado é construído pela linguagem nas diferentes práticas sociais.

A Linguística Sistêmico-Funcional "vê a língua como redes de sistemas linguísticos interligados, das quais nos servimos para construir significados, fazer coisas no mundo" (FUZER; CABRAL, 2014, p 19). Antes de avançar, considero relevante apontar que o pensamento sistêmico é uma abordagem que compreende a vida sob a perspectiva da complexidade, olhando não somente para o indivíduo isoladamente, mas também para o contexto e as relações estabelecidas. $\mathrm{O}$ pensamento sistêmico refere-se à compreensão de que todo organismo é um “sistema vivo 'aninhado' dentro de outros sistemas vivos", ou seja, "redes dentro de redes" e que "nenhum organismo individual pode existir isoladamente" (CAPRA, 2006a, p. 51-52). Nesta percepção de mundo, a interdependência é inerente aos fenômenos físicos, psicológicos, biológicos, sociais e culturais. É possível, então, entender o universo como uma rede de fenômenos interconectados e interdependentes; reconhecer o valor intrínseco de todos os seres vivos; e conceber os seres humanos como um fio particular da teia da vida 
(CAPRA, 2006b). Acredito que a noção de rede vista no pensamento sistêmico nos ajuda a compreender que, na Linguística Sistêmico-Funcional, "cada sistema é um conjunto de alternativas possíveis que podem ser semânticas, léxicogramaticais ou fonológicas e grafológicas” (FUZER; CABRAL, ibidem).

Para Martin (2001, p. 142) "um sistema é um conjunto de opções, disponíveis a falantes/escritores, que abarca significados que são tipicamente expressos em contextos particulares, bem como também as formas linguísticas necessárias para tal expressão". A Linguística Sistêmico-Funcional é uma teoria que concebe a linguagem como uma rede de possibilidades, na qual os falantes/escritores fazem escolhas. As escolhas são realizadas dentro das possibilidades que o sistema linguístico disponibiliza para veicular significados determinados em contextos específicos. Segundo Halliday (1970, p. 142 apud FUZER; CABRAL, 2014, p. 26), “o sistema de opções válidas é a gramática da língua, e o falante ou escritor seleciona desse sistema: não no vácuo, mas no contexto de situações de fala”. É a partir dos elementos da cultura que o falante/escritor seleciona o modo e a forma de produção do texto falado ou escrito. As atividades humanas são mediadas pela linguagem, o que requer de seus usuários uma grande experiência no que se refere ao reconhecimento, diferenciação e classificação dessas escolhas em situações diversas. Assim, o contexto assume papel fundamental na Linguística Sistêmico-Funcional.

$\mathrm{Na}$ teoria de Halliday, a linguagem é dividida em três estratos: grafofonológico, léxico-gramatical e semântico-discursivo, que são realizados em contextos de cultura e de situação. O contexto de cultura é amplo e envolve o contexto histórico de uma comunidade assim como a cultura de seus participantes. O contexto de situação é dividido em três variáveis - campo, relações e modo (HALLIDAY, 1994; HALLIDAY; HASAN, 1989). Nessa dissertação, o contexto de situação apresenta-se da seguinte maneira: o campo refere-se à atividade social que os participantes encontram-se envolvidos, ou seja, as minhas vivências e experiências como pesquisadora e dos alunos participantes no Programa Bilíngue da escola. Relações referem-se à natureza dos participantes, seus papéis e relacionamentos, em outras palavras, a distância social entre eu, professorapesquisadora, e os alunos participantes, a qual pode ser considerada mínima por haver um contato próximo e face a face. O modo diz respeito ao papel da linguagem, incluindo o canal e a modalidade retórica, sendo que, nas conversas 
gravadas o canal utilizado é o fônico e o meio é oral. Já nas Atividades Pedagógicas com Potencial Exploratório apresentadas, o meio é o escrito.

As variáveis campo, relações e modo apresentam uma relação sistemática e dialética com as três metafunções que são ideacional, interpessoal e textual. Dessa forma, o campo é expresso pela função ideacional; as relações, pela função interpessoal; e modo pela metafunção textual. As metafunções realizam-se a partir das necessidades do contexto de situação de fala. Halliday e Matthiessen (2014) apontam que a linguagem é um sistema utilizado para criar significados em interações sociais a partir de escolhas paradigmáticas. Estas escolhas acontecem de acordo com o uso que fazemos da linguagem, ou seja, usamos a linguagem para falar de nossas experiências sobre o mundo - metafunção ideacional; para estabelecer e manter relações sociais - metafunção interpessoal; e para organizar nossa mensagens, relacionando-as com outras mensagens - metafunção textual.

Vale a pena destacar que "para Halliday, a linguagem é um sistema de escolhas, nem sempre conscientes" (THOMPSON, 2014, p. 35), portanto, as escolhas léxico-gramaticais realizadas pelos alunos participantes encontram-se atreladas ao contexto no qual estão inseridos, já apresentado no capítulo 2. Tais escolhas não aconteceram por acaso; são fruto de algumas preferências lexicais em detrimento de outras e estão diretamente relacionadas às suas idades cronológicas, às vivências familiares, e às experiências socioculturais de cada um.

\subsection{1. O Sistema de Avaliatividade}

Para Martin e White (2005), o Sistema de Avaliatividade está em consonância com a Linguística Sistêmico-Funcional porque as escolhas não acontecem por acaso; e sim como resultado de preferências léxico-gramaticais realizadas pelo falante/escritor. Além disso, a teoria analisa a língua em uso, destacando o aspecto social da linguagem. Para os autores, o Sistema de Avaliatividade possibilita que o pesquisador analise aspectos de avaliação presentes no discurso, o qual é produzido na esfera social, formado por crenças e valores individuais, em contextos diversos.

O Sistema de Avaliatividade encontra-se na interface entre a semântica do discurso e o léxico da gramática, inserido em um contexto sócio-histórico, cultural 
e institucional. Em outras palavras, o significado é criado no contexto, assim é observado a partir do discurso, na interação, na linguagem em uso. O Sistema de Avaliatividade divide-se em três subsistemas inter-relacionados: atitude, engajamento e gradação (MARTIN; ROSE, 2003; THOMPSON; 2014, p. 79-83). De forma sucinta, a atitude enfoca sentimentos e reações emocionais; o engajamento lida com a origem das atitudes e com as vozes em relação a opiniões no discurso; a gradação busca situar os fenômenos de acordo com a intensidade com que ocorrem.

O subsistema atitude divide-se em três campos semânticos: afeto, julgamento e apreciação. Segundo Nóbrega (2009, p. 93), “apesar de cada um destes subsistemas possuírem características individuais [...], se encontram interligados a partir do Afeto". Para representar esta noção de interligação, a autora sugere a figura a seguir, a qual mostra que o Afeto engloba tanto o julgamento quanto a apreciação.

Quadro 2 - Representação do afeto no julgamento e na apreciação (NÓBREGA, 2009, p. 94)

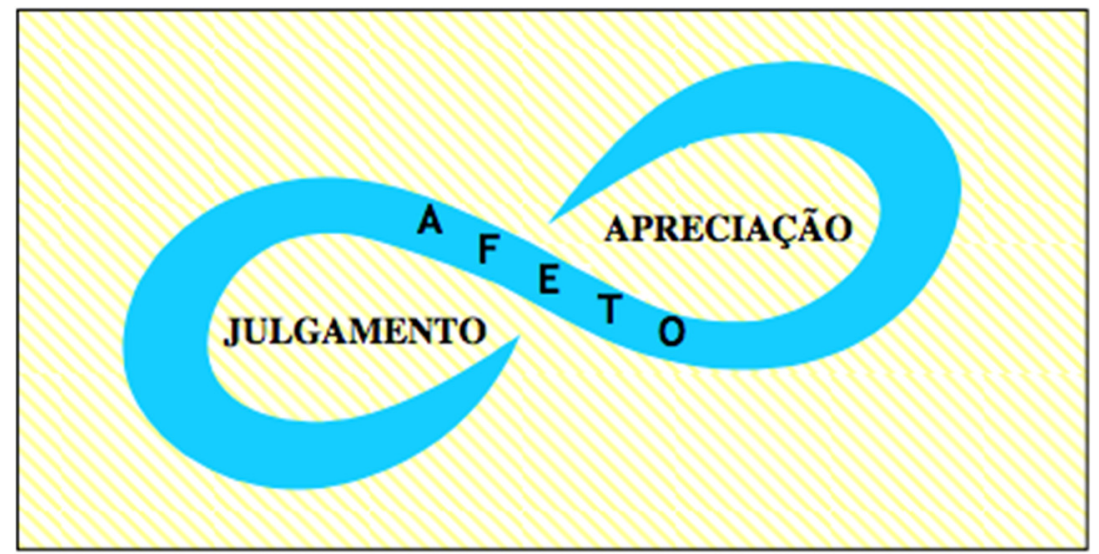

A imagem nos permite entender que o afeto é o "sistema básico" (MARTIN, 2001, p. 147 apud NÓBREGA, 2009), o qual permeia tudo e está institucionalizado no julgamento e na apreciação. Baseando-me em Martin e White (2005, p. 43-44), é possível inferir que (i) afeto está ligado às emoções, reações ao comportamento, texto/processo, e fenômeno; (ii) julgamento relacionase à ética e avaliação do comportamento; (iii) apreciação refere-se à estética, avaliação texto/processo e fenômeno natural. 


\subsection{1.}

\section{Afeto, Julgamento e Apreciação}

Afeto (NÓBREGA, 2009) é o primeiro campo semântico do subsistema da Atitude, diz respeito à construção das emoções e encontra-se centrado no avaliador. $\mathrm{O}$ afeto pode ser expresso na primeira pessoa - afeto autoral, ou na segunda e terceira pessoa - afeto não autoral. $O$ afeto autoral indica que o indivíduo assume responsabilidade por sua avaliação, respondendo emocionalmente à pessoa, à coisa, ao acontecimento ou à situação que desencadeia a emoção. Um indivíduo pode avaliar outrem enquanto, simultaneamente, se apresenta para avaliação através daquela emoção. Assim, a avaliação emocional é subjetiva e individual.

Segundo White (2004, p. 184-187), lexicalmente, o afeto pode ser expresso através dos seguintes elementos: pelos processos mentais emotivos (amar, gostar, odiar, etc.), comportamentais (chorar, sorrir, etc.) e relacionais atributivos (ser); pelas circunstâncias de modo (felizmente, infelizmente, etc.); e pelas nominalizações (felicidade, tristeza, etc.) No exemplo "I love my school", retirado do texto que Bruna escreveu para descrever a escola (seção 6.2.), a aluna se posiciona como autora realizando uma avaliação no campo do afeto, de forma positiva, com o uso de um processo mental emotivo de alta gradação.

O segundo campo semântico do subsistema Atitude é o julgamento. Esta categoria critica ou elogia, condena ou aplaude o comportamento, as ações, os feitos, as crenças, as motivações de indivíduos ou grupos, referindo-se às regras e convenções. "O julgamento refere-se ao universo das propostas sobre comportamento" (VIAN JR, 2010, p. 20). O julgamento depende da posição ideológica do avaliador e está relacionado à moralidade, legalidade, capacidade, normalidade de acordo com a cultura, às experiências individuais e coletivas, às crenças, às suposições e às expectativas do avaliador.

De acordo com White (2004), julgamento é o campo de significados pelo qual construímos nossas posições em relação ao comportamento humano, em referência à aceitabilidade e às normas sociais e avaliamos o caráter de alguém ou o quanto uma pessoa se aproxima das exigências e expectativas sociais e culturais.

O julgamento pode ser subdividido em estima social e sanção social. O primeiro envolve admiração e crítica sem implicações legais enquanto o segundo 
envolve elogios e censuras com implicações legais. Os comportamentos julgados como positivos em estima social são aqueles que remetem à admiração, ao passo que comportamentos julgados como negativos são os que remetem à crítica. $\mathrm{O}$ julgamento de estima social apresenta-se em três modalidades: normalidade, capacidade e tenacidade. O primeiro julga se os comportamentos são usuais, habituais, corriqueiros, ou seja "o quão frequente um comportamento é. O segundo refere-se à competência de alguém para realizar algo ou alguma atividade - o quão capaz uma pessoa é. O terceiro é o julgamento sobre as boas intenções ou atitudes que inspirem confiança - o quão resistente ou resoluta uma pessoa é.

No exemplo "The teachers are very nice", retirado do texto que Daniel escreveu para descrever a escola no capítulo 6 (seção 6.2.), o aluno realiza uma avaliação positiva no campo do julgamento, com o uso de um processo relacional atributivo. Assim, ser very nice é um atributo das teachers da escola. Daniel realiza um julgamento de estima social de normalidade (o quão especial ou não são as professoras?).

A apreciação é o terceiro campo semântico do subsistema de Atitude e é usada para "construir avaliações dos produtos do trabalho humano, tais como artefatos, edificações, obras de arte, e também de fenômenos naturais e estados de coisas" (WHITE, 2004, p. 191). A apreciação encontra-se ligada à avaliação da aparência ou da estética. Assim como o afeto e o julgamento, a apreciação possui uma dimensão positiva ou negativa. O sistema é organizado em três variáveis reação, composição e valoração (MARTIN, 2003, p. 160-161). A primeira está relacionada ao impacto emocional provocado na pessoa; melhor compreendido pelas perguntas: 'o quão isto chama minha atenção?' ou 'isto me agrada?' A segunda, a composição, refere-se à percepção da proporcionalidade e dos detalhes; melhor entendida com as perguntas: 'isto articula-se entre si?' ou 'é difícil entender/acompanhar?' A terceira está ligada à avaliação do significado social; entendida com as perguntas: 'vale(u) a pena?', 'é vantajoso?'

No exemplo "It is very beautiful and big", retirado do texto que Gael escreveu para descrever a escola no capítulo 6 (seção 6.2.), o aluno realiza uma avaliação positiva da escola no campo da apreciação na categoria de reação (prendeu minha atenção? eu gostei?). Nesse sentido, Gael faz uma avaliação estética atribuindo os valores beautiful e big para a escola. 
Os três campos semânticos - afeto, julgamento e apreciação - contribuem para fundamentar a análise discursiva dos fragmentos das conversas exploratórias gravadas com os alunos participantes, apresentadas no capítulo 7. É essencial lembrar que, de acordo com Martin (2003, p. 161-162), a avaliação que realizamos depende da posição institucional que ocupamos. Diante disso, reforço que as análises micro-discursivas foram realizadas por mim, sem a participação dos alunos, o que torna as análises uma interpretação subjetiva do que foi dito por eles no momento das gravações.

Com a intenção de ilustrar e recapitular os três campos semânticos apresentados, elaborei um quadro inspirado nas tabelas de Martin (ibidem, p. 149161), a seguir.

Quadro 3 - Afeto, Julgamento e Apreciação (MARTIN, 2003)

\begin{tabular}{|c|c|c|c|}
\hline \multicolumn{4}{|c|}{ Subsistema de Atitude } \\
\hline Afeto & $\begin{array}{l}\text { felicidade/infelicidade } \\
\text { segurança/insegurança } \\
\text { satisfação/insatisfação }\end{array}$ & \multicolumn{2}{|c|}{$\begin{array}{l}\text { sentimentos e emoções "ligados ao coração" } \\
\text { bem-estar "eco-social" } \\
\text { busca de objetivos }\end{array}$} \\
\hline \multirow[t]{2}{*}{ Julgamento } & estima social & $\begin{array}{l}\text { normalidade } \\
\text { capacidade } \\
\text { tenacidade }\end{array}$ & $\begin{array}{l}\text { ele/ela é especial? } \\
\text { ele/ela é capaz? } \\
\text { ele/ela é de confiança? }\end{array}$ \\
\hline & sanção social & $\begin{array}{l}\text { veracidade } \\
\text { propriedade }\end{array}$ & $\begin{array}{l}\text { ele/ela é honesto(a)? } \\
\text { ele/ela é correto(a)? }\end{array}$ \\
\hline \multirow{3}{*}{ Apreciação } & reação & $\begin{array}{l}\text { impacto } \\
\text { qualidade }\end{array}$ & $\begin{array}{l}\text { prendeu minha atenção? } \\
\text { eu gostei? }\end{array}$ \\
\hline & composição & $\begin{array}{l}\text { equilíbrio } \\
\text { complexidade }\end{array}$ & $\begin{array}{l}\text { faz sentido? } \\
\text { foi difícil acompanhar? }\end{array}$ \\
\hline & valor & & valeu a pena? \\
\hline
\end{tabular}

Baseada neste quadro, buscarei analisar as escolhas avaliativas feitas pelos alunos em seus textos escritos e durante as conversas exploratórias, tendo como guia o subsistema de Atitude nos campos do afeto, do julgamento e da apreciação, vistos na semântica do discurso e realizados na léxico-gramática.

Neste capítulo, apresentei diretrizes para as reflexões que busco tecer ao longo desse trabalho inclusivo, caracterizado como uma pesquisa do praticante no 
ambiente acadêmico da Linguística Aplicada. As (pre)disposições pessoais e profissionais do professor (NÓVOA, 2009), as crenças e as emoções na educação (BARCELOS, 2019) e o Sistema de Avaliatividade (MARTIN; WHITE, 2005; NÓBREGA, 2009) oferecem suporte para as análises realizadas nos próximos capítulos, tendo os princípios da Prática Exploratória como guia. No próximo capítulo, incluo duas Atividades Pedagógicas com Potencial Exploratório, as quais ilustram a busca por melhor entender as concepções dos alunos participantes a respeito de quem é o professor de inglês, no contexto do Programa Bilíngue da escola. 


\section{5 \\ O professor no Programa Bilíngue da escola}

Neste capítulo, tenho como objetivo refletir e buscar entender como os participantes desta pesquisa percebem o professor de inglês nos primeiros anos de escolarização, mais especificamente no Programa Bilíngue da escola. Para tal, apresento duas Atividades Pedagógicas com Potencial Exploratório, as quais se relacionam com a busca conjunta realizada pelos sete alunos participantes e eu, professora-praticante.

\section{1.}

\section{Formação pessoal, acadêmica e profissional}

"Você não pode separar o ensinar do aprender; é impossível compreender a prática do ensinante sem compreender a prática do aprendiz" (FREIRE, [1995] 2018c, p.180-181). Em consonância com esse pensamento, para os membros da Prática Exploratória, somos todos aprendizes (cf. learners) em posições diferentes, ora alunos, ora professores. Assim, ao se formar professor, a pessoa já tem muitas experiências como aluno, pois "os professores são trabalhadores que foram mergulhados em seu espaço de trabalho durante aproximadamente 16 anos" (TARDIF, 2000, p. 13). Para Piedade (2019, p. 14), "grande parte de nossa vida seja na infância, na adolescência ou na fase adulta - é atravessada por experiências de cunho pedagógico". O autor, em sua dissertação de mestrado, discute a trajetória de formação educacional do professor. Nessas discussões, fica claro que o professor vivencia longas experiências como aluno em vários segmentos, como estagiário supervisionado por professores, como professor, como aluno de pós-graduação, como professor-pesquisador, o que me leva a considerar que esses papéis sociais contribuem para a formação pessoal, acadêmica e profissional do professor ao longo de sua história de vida.

Os três níveis de formação - pessoal, acadêmico e profissional - devem ser entendidos como um processo de construção "que tem a marca das experiências feitas, das opções tomadas, das práticas desenvolvidas, das continuidades e descontinuidades, quer ao nível das representações quer ao nível do trabalho concreto" (MOITA, 2015, p. 116). O processo de formação é 
individual, ou seja, cada professor-educador transita por uma rota e "ao longo de sua história, se forma, se transforma" (MOITA, ibidem, p. 115).

Freire ([1996] 2018a, p. 89-90) afirma que "o professor que não leve a sério sua formação, que não estude, que não se esforce para estar à altura se sua tarefa não tem força moral para coordenar as atividades de sua classe”. O autor acrescenta que a "competência científica" sozinha não indica competência profissional. A formação profissional inclui, nas palavras de Freire, generosidade, comprometimento, tolerância, bom-senso, respeito, curiosidade, reflexão crítica sobre a prática, entre outros.

A respeito do processo de formação, parece impossível desconectar as três dimensões como se ocorressem separadamente. Nesse viés, Nóvoa (2009, p. 38) aponta que "ensinamos aquilo que somos e que, naquilo que somos, se encontra muito daquilo que ensinamos". Gieve e Miller (2006) corroboram com esta ideia, assim como Freire (2001, p. 40), quem nos lembra que nossas atividades profissionais estão ligadas à "nossa presença no mundo". Com isto em mente, é possível inferir que a trajetória do professor-educador está centrada nos processos de formação pessoal, acadêmica e profissional.

Vale enfatizar que as três dimensões mencionadas desenrolam-se nas interações, no convívio, no diálogo com o outro, os quais acontecem na vivência familiar, na formação escolar e universitária, na interação com alunos, coordenadores, colegas de trabalho. Esta teia de relacionamentos está permeada de emoção. Nas palavras de Freire ([1981] 2018b, p. 36), "não há educação sem amor. [...] Quem não ama não compreende o próximo, não o respeita”. Assim, entendo que o afeto está no cerne das inter-relações que ocorrem na sala de aula, na escola, e fora dela também.

No Programa Bilíngue, ao vivenciar e experienciar os três níveis de meu processo de formação, busco entender quem é o professor de inglês no olhar dos sete alunos participantes.

\section{2.}

\section{As atividades}

Com a intenção de trazer para a dissertação a voz autoral de cada aluno participante, optei por apresentar as Atividades Pedagógicas com Potencial 
Exploratório exatamente como foram elaboradas por eles. Dessa forma, as atividades foram digitalizadas por mim com o cuidado para que os nomes dos alunos fossem omitidos.

Sendo parte das aulas, todas as etapas das Atividades Pedagógicas com Potencial Exploratório foram realizadas em inglês. Outro ponto que vale ser lembrado é que as atividades são apresentadas sem nenhum tipo de interferência da minha parte com relação à ortografia ou gramática. Como o conhecimento linguístico é construído diariamente no Programa Bilíngue, a omissão de letras ou uma escrita aproximada com a língua falada fazem, sem dúvida, parte do processo de construção da linguagem, no qual os alunos vivenciam. O processo da escrita indica que os alunos encontram-se em estágios de desenvolvimento pertinentes às suas faixas etárias e experiências pessoais. Aproveito, então, para ressaltar que minha postura como professora do Programa Bilíngue tem sido não olhar para estas ocorrências como erros que precisam ser corrigidos, mas sim como material para ser trabalhado no contexto pedagógico, visando novas conquistas por parte da criança. Isso posto, prossigo apresentando as atividades.

\section{3. \\ Primeira Atividade Pedagógica com Potencial Exploratório}

A primeira Atividade Pedagógica com Potencial Exploratório foi realizada na sala de aula. O registro dos alunos foi individual feito numa folha branca A4, a partir da proposta de completar o que escrevi no quadro - A good English teacher. Escolhi não dar exemplos nem conversar antes para não influenciar a escrita deles. A disposição das carteiras na sala permitiu interação e pedi que eles tentassem escrever sem conversar com o colega, o que não foi rigorosamente cumprido, pois estão acostumados a interagir durante as atividades. Quando terminaram, recolhi suas produções sem as dividir com o grupo, ou fazer comentários, o que somente aconteceu em aulas seguintes.

No centro da folha, os alunos escreveram A good English teacher, circularam a frase e traçaram linhas para completar o pensamento. Reproduzo, a seguir, a atividade de cada aluno participante. 


\section{Giovana}

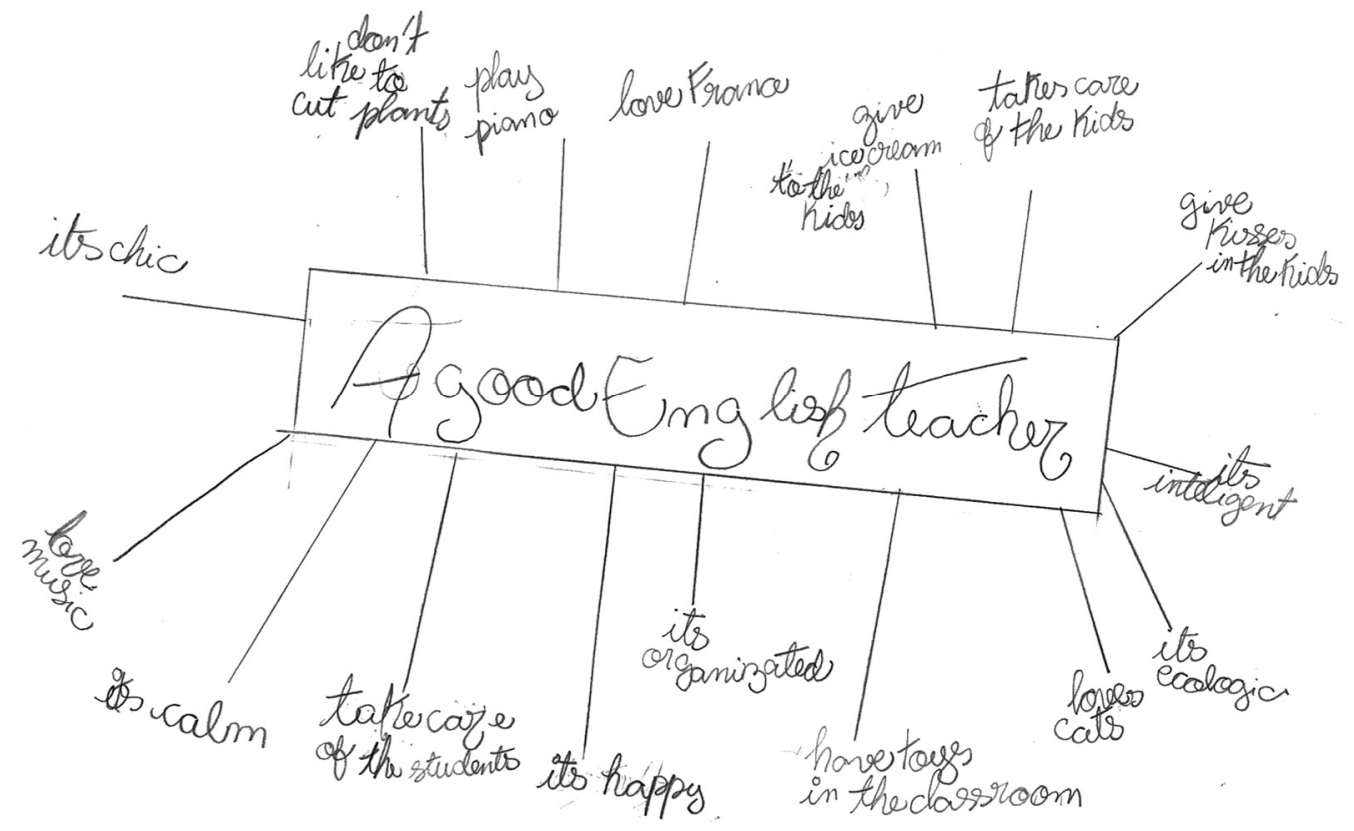

ป

\section{Theo}

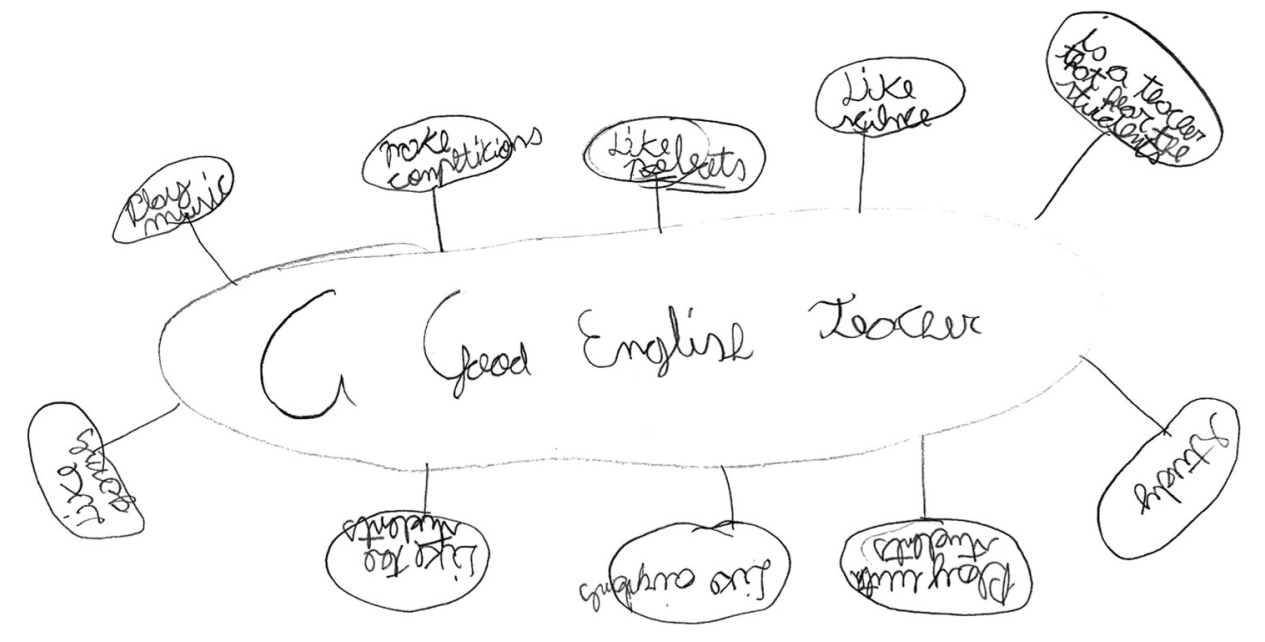




\section{Tito}

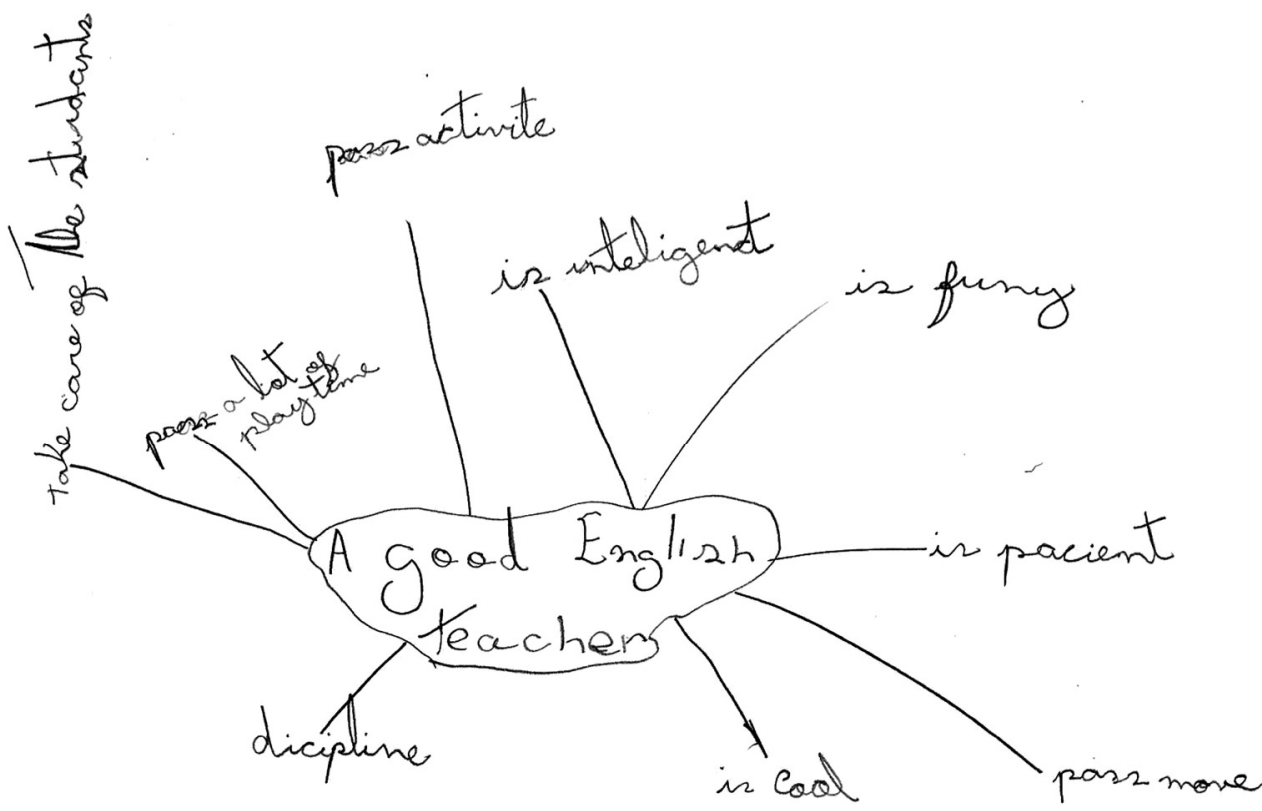

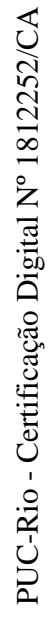

\section{Breno}

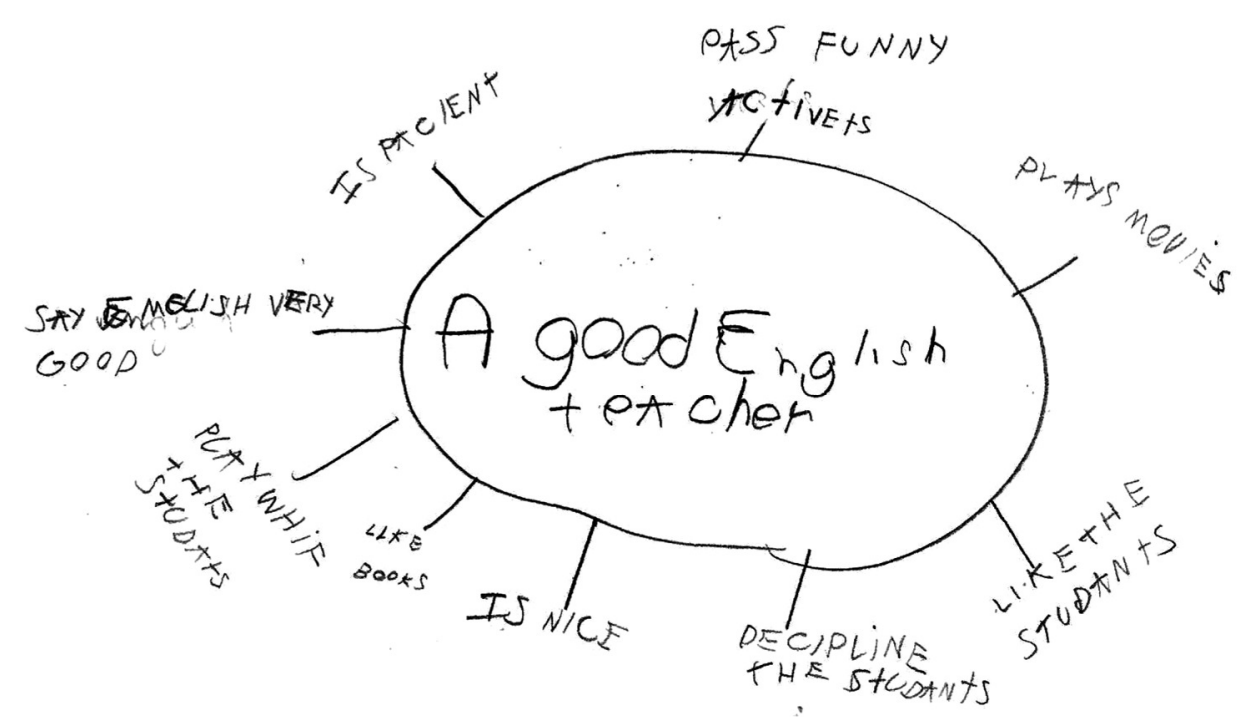




\section{Daniel}

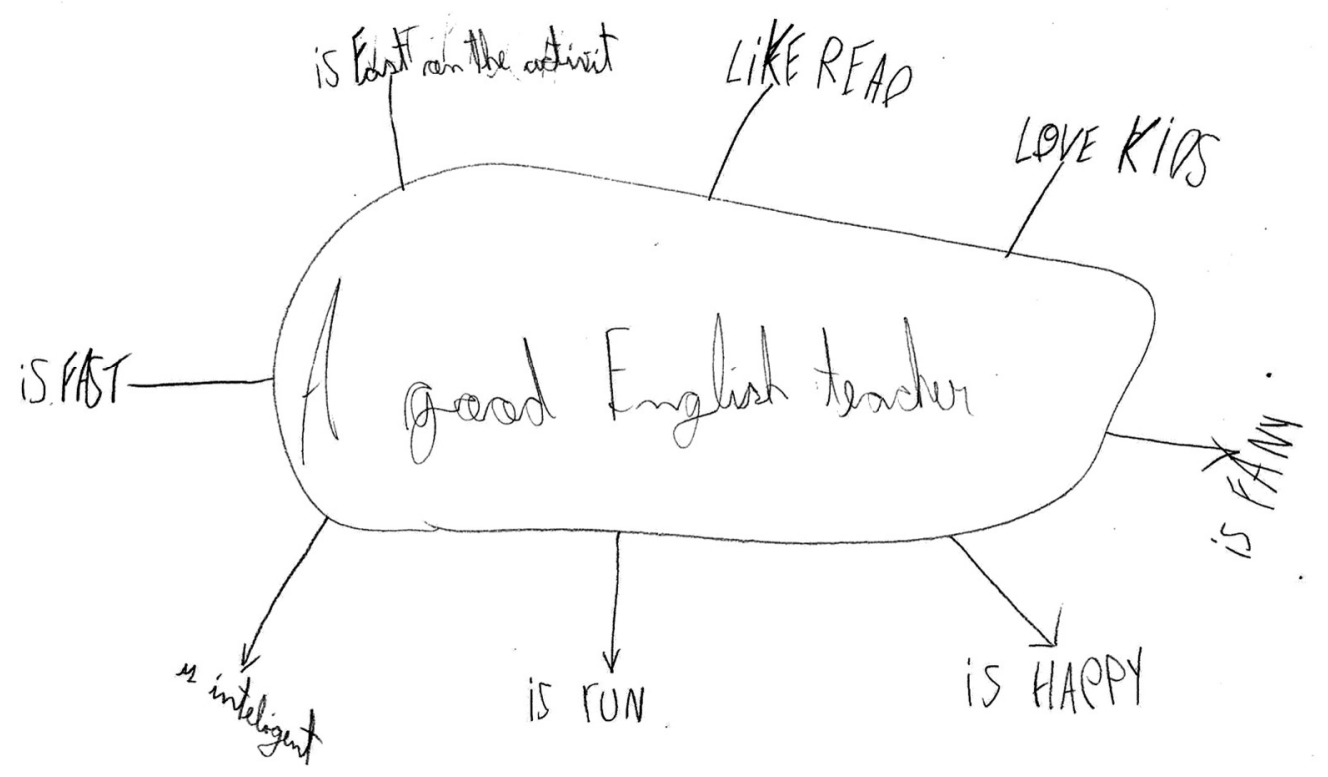

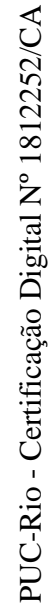

\section{Gael}

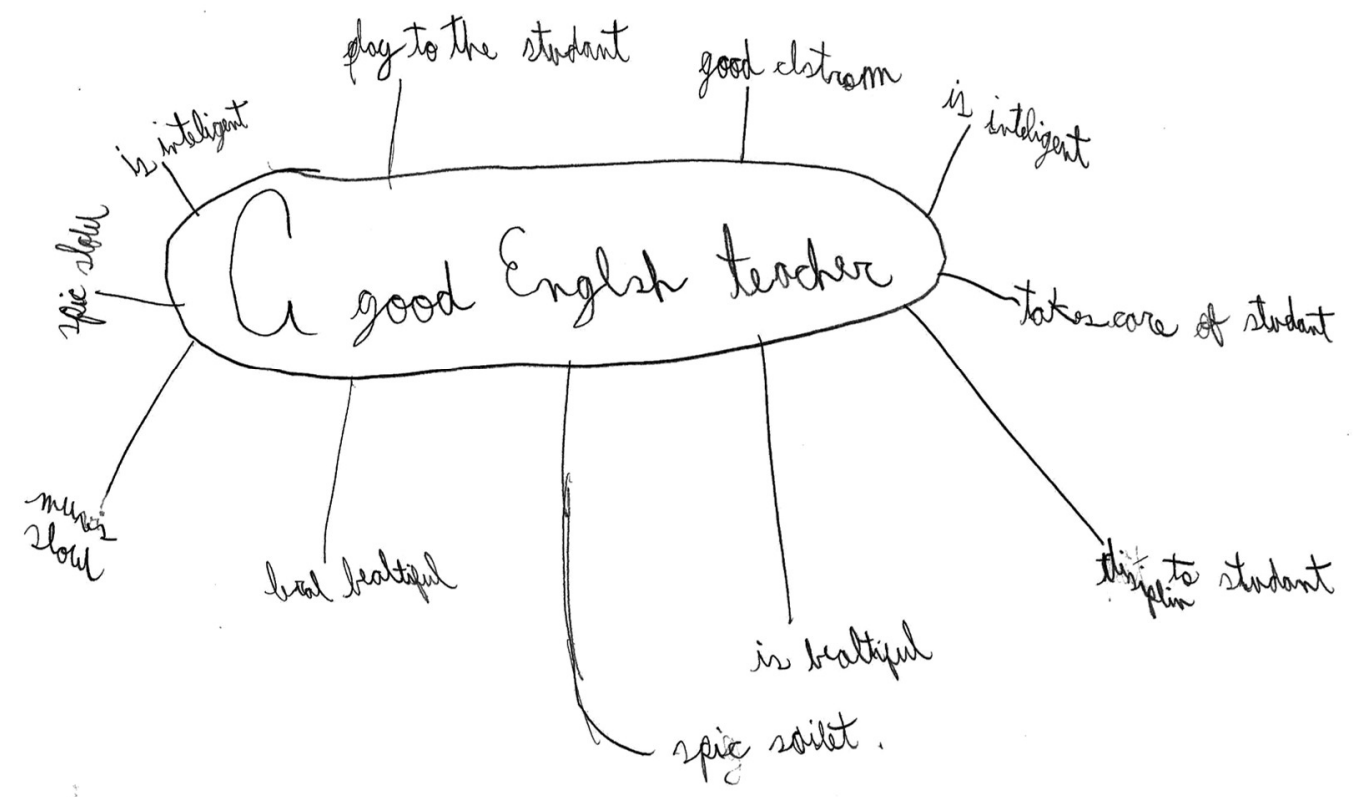




\section{Bruna}

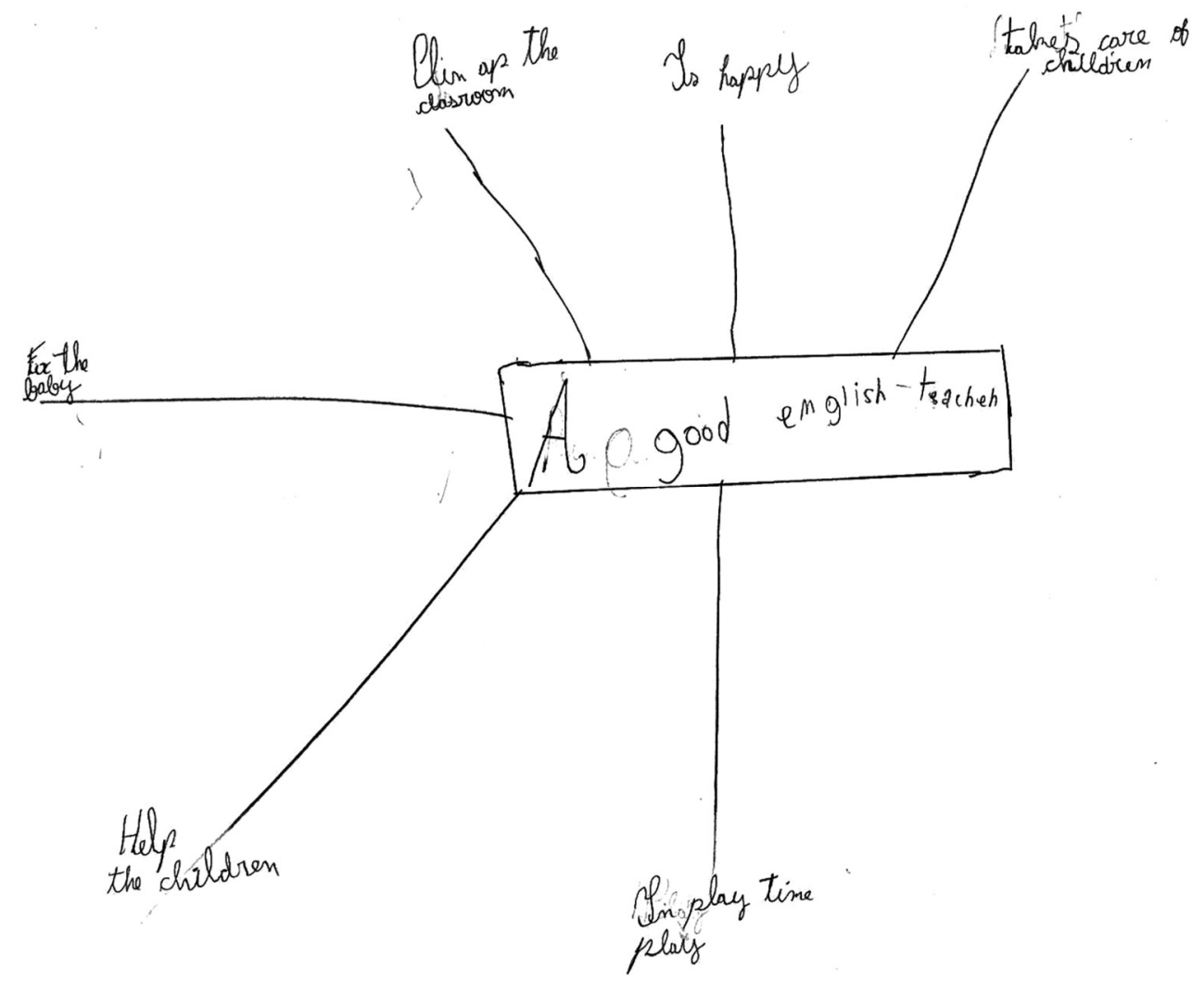

\subsection{1.}

\section{Afinal, quem é o bom professor de inglês?}

Conforme já mencionado no capítulo 2 (seção 2.4.), a Atividade Pedagógica com Potencial Exploratório é uma atividade de rotina escolar, na qual os praticantes, alunos e professores, se envolvem na busca de maiores entendimentos das suas questões cotidianas. A primeira atividade aqui descrita surgiu de uma questão minha. Como professora, observei várias conversas entre os alunos participantes, nas quais elogiavam ou criticavam atitudes e comportamentos de outros professores da escola durante nossas aulas. Com frequência, falavam 'professor chato', 'professor maneiro' e assim por diante. Foi neste momento que surgiu a vontade de buscar entender melhor quem seria um bom professor para os sete alunos da turma.

Mais uma vez, ressalto que reconheço os alunos participantes como agentes sociais capazes de interpretar o mundo à sua volta. Portanto, entendo que os alunos trazem para a atividade proposta suas visões de mundo, suas crenças, 
suas vivências educacionais e suas experiências dentro e fora da escola. Registrar suas perspectivas e saberes, na minha opinião, enriquece a pesquisa.

Após minha leitura das atividades, com um olhar investigativo, pude notar que os alunos participantes se expressam com propriedade a respeito do professor de inglês, indicando atitudes e comportamentos por eles observados, percebidos e sentidos. Acho importante levar em consideração que a maneira como os alunos participantes expressam suas ideias parece coerente com sua idade e com os conhecimentos que já têm do idioma. Reforço, portanto, que todas as Atividades Pedagógicas com Potencial Exploratório foram realizadas em inglês.

Com a intenção de refletir e buscar maiores entendimentos, organizei as atividades apresentadas na seção anterior da seguinte maneira: na coluna da direita, os atributos/adjetivos escolhidos pelos alunos para definir um bom professor de inglês; e, na coluna da esquerda, os processos/verbos por eles empregados. Para facilitar a leitura, deixei entre colchetes palavras que sofreram minha interferência, assim como palavras as quais não consegui identificar.

\section{Quadro 4 - Primeira Atividade Pedagógica com Potencial Exploratório}

\begin{tabular}{|c|c|}
\hline Atributos/adjetivos & Processos/verbos \\
\hline $\begin{array}{l}\text { intelligent } \\
\text { happy } \\
\text { funny } \\
\text { patient } \\
\text { nice } \\
\text { beautiful } \\
\text { cool } \\
\text { organized } \\
\text { calm } \\
\text { chic } \\
\text { eco-[friendly] } \\
\text { fast }\end{array}$ & $\begin{array}{l}\text { take care of the students/kids } \\
\text { play with the students } \\
\text { discipline the students } \\
\text { like the students; love kids } \\
\text { help the children } \\
\text { [assign] activities/funny activities } \\
\text { like to read; study } \\
\text { like robots; science; airplanes; games } \\
\text { make competitions } \\
\text { play movies; play music } \\
\text { hear [listen to] the students } \\
\text { [give] a lot of playtime } \\
\text { move slowly } \\
\text { speak slowly; [?] speak silent } \\
\text { [speak] English very [well] } \\
\text { love France; love cats } \\
\text { doesn't like to cut plants } \\
\text { play the piano } \\
\text { give ice cream to the kids } \\
\text { give kisses to the kids } \\
\text { have [keep] toys in the classroom } \\
\text { clean up the classroom } \\
\text { [?] fix the baby }\end{array}$ \\
\hline
\end{tabular}


Acho pertinente apontar que os atributos/adjetivos mais usados, pelos alunos, foram: intelligent, happy, funny e pacient. Contudo, a recorrência do léxico intelligent parece indicar a importância dada ao aspecto cognitivo, enquanto happy, funny e patient relacionam-se às habilidades interpessoais do professor. Os adjetivos nice e cool foram escolhidos pelos alunos no sentido de 'legal', palavra comum em seus repertórios linguísticos. Já beautiful e chic referem-se à aparência física do(a) professor(a).

$\mathrm{O}$ atributo que mais chamou minha atenção foi eco-friendly, usado pela aluna Giovana. Ao escrever que a good English teacher is ecologic, acredito que Giovana quis ressaltar que o compromisso individual com as questões ambientais deve fazer parte da agenda de professor de inglês.

Em relação aos processos/verbos, a recorrência de take care of the students e play with the students pode estar ligada às habilidades interpessoais, afetivas e pedagógicas do professor, as quais são vivenciadas pelos alunos no dia-a-dia. Ambos 'cuidar' e 'brincar' são processos materiais e representam nossa experiência no mundo exterior (HALLIDAY; MATTHIESSEN, 2014). No contexto sociocultural, no qual o Programa Bilíngue está inserido, o afeto pode ser manifestado em aproximações físicas como abraço, beijo e colo, comuns na interações professora-alunos nos anos iniciais da escolarização.

Outro processo escolhido por três alunos foi discipline, um possível sinônimo de educate, ou seja, o professor como figura responsável por disciplinar/educar os alunos. Entendo disciplina, no ambiente do Programa Bilíngue, mais especificamente na turma dos sete alunos participantes, como a obediência a um conjunto de regras de conduta e de comportamento; de cumprimento de horários; de uso de uniforme; de cuidado com o material individual e coletivo; e de respeito ao outro. Nesse sentido, disciplina não tem a ver com autoritarismo, mas sim com responsabilidade e compromisso. Acho que uma das tarefas do professor é ajudar seus alunos a compreender que suas posturas e ações devem/deveriam contribuir para o bem-estar da comunidade escolar.

No desenrolar do meu processo de reflexão, observei a materialização do afeto nas escolhas léxico-gramaticais realizadas pelos alunos. O afeto está presente em take care of, play with, listen to, help, like, love, entre outros. Relembrando que nossas escolhas nem sempre são conscientes (THOMPSON, 
2014), que a avaliação que fazemos depende de nossa posição institucional (MARTIN, 2003), e que o afeto encontra-se ligado às emoções que permeiam as relações humanas (NÓBREGA, 2009). Com isso em mente, como professorapesquisadora envolvida em um contexto sócio-histórico-cultural situado, arrisco afirmar que escola é lugar de afeto(s).

Ainda sobre a primeira Atividade Pedagógica com Potencial Exploratório, foi possível interpretar que o atributo intelligent, usado pelos alunos, nos remete a uma característica intelectual relacionada ao conhecimento, ao raciocínio, à memória e à cognição, ao passo que, take care of e play with nos remete à interação sócio-afetiva entre professores e alunos.

Com muitos porquês na cabeça, resolvi propor outras atividades.

\section{4 . \\ Segunda Atividade Pedagógica com Potencial Exploratório}

As Atividades Pedagógicas com Potencial Exploratório podem ser desenvolvidas em várias etapas, sendo um processo sem fim, pois uma questão pode levar a outras infinitamente. A busca por entendimentos é relacionada a questões situadas e localizadas, nas quais os praticantes exploratórios encontramse envolvidos. Em outras palavras, a busca por entendimentos na sala de aula relaciona-se ao contexto que os praticantes vivenciam em sua rotina. Essa busca leva professores e alunos a trabalharem juntos envolvidos em "práticas pedagógicas que reativam suas curiosidades naturais acerca de vários aspectos de suas vidas" (MILLER; CUNHA, 2019, p. 587-588). Os aspectos podem ser de ordem pessoal, social, cultural e são integrados ao que acontece durante os momentos de ensino e aprendizagem e de interação entre os praticantes.

Assim como a primeira, a segunda Atividade Pedagógica com Potencial Exploratório também foi realizada na sala de aula. Sugeri que os alunos imaginassem que iriam entrevistar um(a) professor(a) para trabalhar na escola no segmento do Programa Bilíngue, elaborando seis perguntas. O registro feito pelos alunos foi individual, em uma folha branca, formato A4.

Em uma leitura inicial, notei que os sete alunos participantes escreveram as duas perguntas que, para eles, podem fazer parte do gênero entrevista: What is your name? e How old are you? Além dessas, elaboraram outras perguntas 
específicas e coerentes que sugerem seus conhecimentos do gênero entrevista de trabalho, o que, na minha opinião, indica maturidade pois são crianças de 10/11 anos.

Também, gostaria de destacar que a aluna Giovana escreveu uma pergunta, a qual ela denominou de extra - Do you believe in unicorns? Com a intenção de contextualizar sua pergunta, aponto para o fato de a figura do unicórnio ter se tornado popularizada como personagem de mochilas, estojos, capas de cadernos, chaveiros, copos de plástico, estampas de roupas e muito mais. O unicórnio é uma figura mitológica, presente em muitas histórias infantis, usualmente representado por um cavalo branco com um chifre na cabeça. Dessa forma, acreditar em unicórnio é acreditar em seres fantásticos que habitam o universo infantil de lendas e contos de fadas. Acho que, com esta pergunta, Giovana tinha a intenção de saber se o professor pertence a esse contexto cultural.

Em seguida, apresento as atividades digitalizadas, sem nenhuma interferência ou qualquer tipo de correção ortográfica feita por mim.

\section{Giovana}

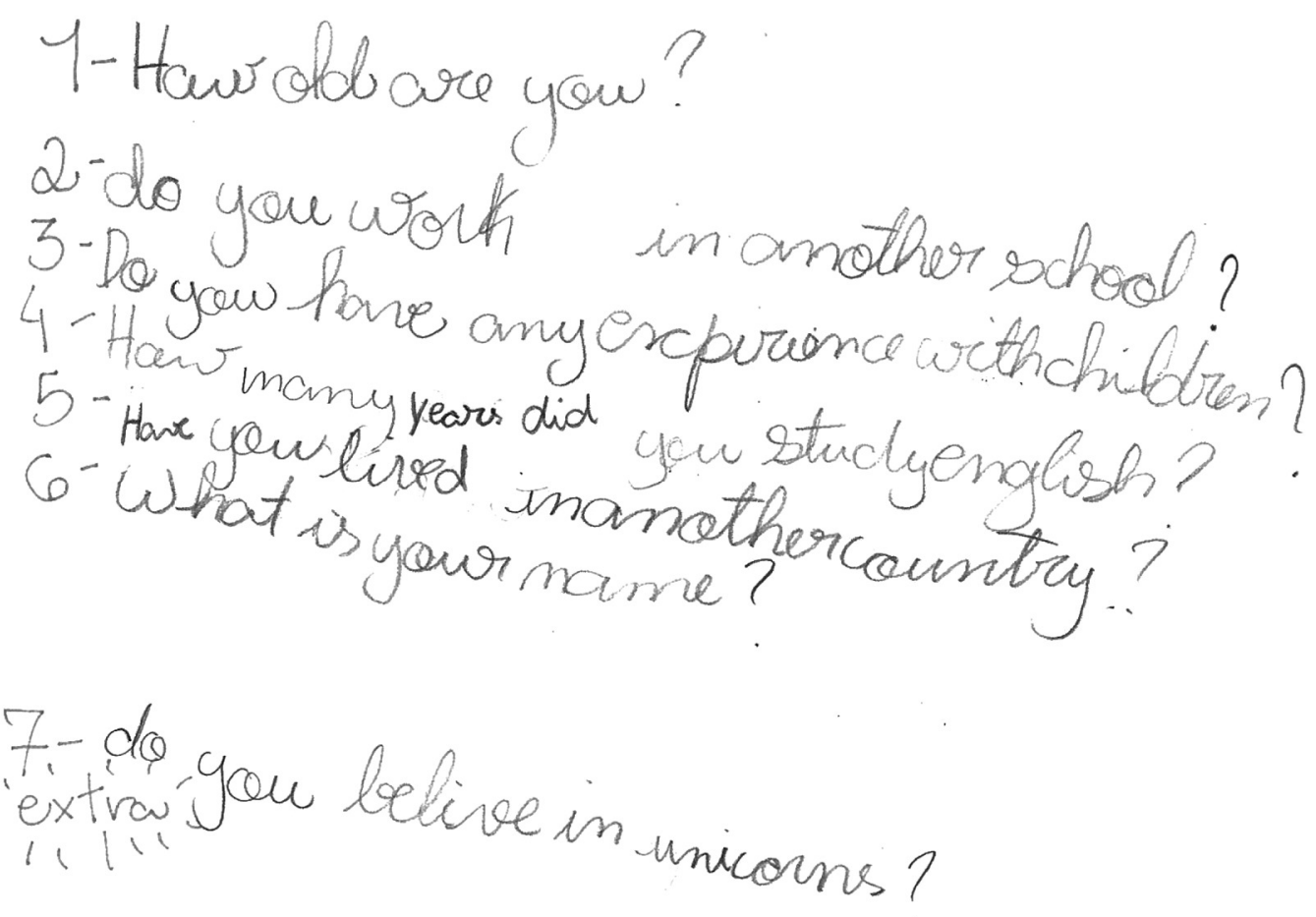


93

Theo

$$
\text { Jnterrieus }
$$

T- Uhat's your mone?

2- Holl you her enarked an a tlocour?

3- Lo your mant to teoch ubst grode?

4- Hour ald aro you?

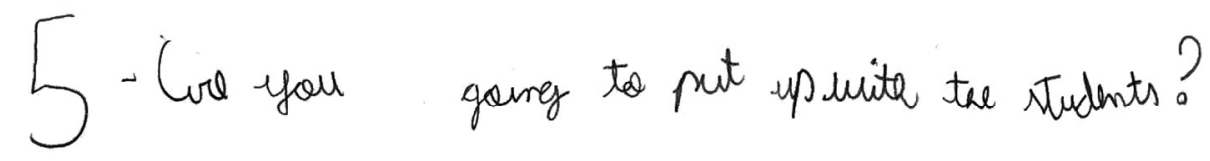

6- Da you like hare? 
94

Tito

Interview

1. What is your name?

2. Do you speak english sire?

3. Haoddare you?

4. In digicalt to be a teacher?

5. De want te the in another place?

6 you like to be a tearer? 
95

Bueno

15 What es your nome?

20 Do you now very good english?

So Do you he books?

$\triangle=$ Do you like kids?

5 What grade you want to be a teacher?

- How del are you?

Daniel

(INTERVIEW)

1. Whativ your mane?

2. Kan like Ba oks?

3. Hall ald are you?

4. You like ta teach in this sepal?

5. What da you teach in this sethaod?

6. Yam hike ploy : Mi th kids? 
96

Gael

1- What is goth name?

2-Houl ald ore gout

3 - You sperry eninglysh very well?

Y- Gre you polait?

5 - You are a teacher serious or a teacher fang?

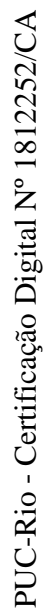

C- Lar are a wry good teacher dou Want to be harvard?

Buna

1 - Chat es your name".

2-How ald ore asper?

3- You have a bother?

4. What is your favorite subject?

5 - Lo you liver a dong?

6 - you liber bids 


\subsection{1.}

\section{Entrevistando o professor de inglês}

Em minha busca por maiores entendimentos, tento analisar as escolhas feitas pelos alunos, materializadas nas perguntas para entrevistar um(a) professor(a) de inglês. Em uma primeira análise, percebi que as perguntas se relacionam com as cinco (pre)disposições sugeridas por Nóvoa (2009) apresentadas e discutidas no capítulo 4. O quadro a seguir mostra minha leitura dessa relação. As perguntas formam digitadas com algumas alterações ortográficas, porém mantive a mesma estrutura gramatical usada por cada aluno.

\section{Quadro 5 - Segunda Atividade Pedagógica com Potencial Exploratório}

\begin{tabular}{|c|c|}
\hline $\begin{array}{l}\text { (Pre)disposições } \\
\text { (NÓVOA, 2009) }\end{array}$ & $\begin{array}{l}\text { Perguntas elaboradas pelos sete alunos } \\
\text { participantes }\end{array}$ \\
\hline Conhecimento & $\begin{array}{l}\text { Do you know very good English? } \\
\text { You speak English very well? } \\
\text { Do you speak English nice [well]? } \\
\text { Have you ever worked as a teacher? } \\
\text { How many years did you study English? } \\
\text { Have you lived in another country? } \\
\text { Do you want to live in another place? }\end{array}$ \\
\hline Cultura profissional & $\begin{array}{l}\text { What grade you want to be a teacher? } \\
\text { Do you want to teach what grade? } \\
\text { You like to be a teacher? } \\
\text { Is it difficult to be a teacher? } \\
\text { Do you work in another school? }\end{array}$ \\
\hline Tato pedagógico & $\begin{array}{l}\text { You like play with kids? } \\
\text { Are you polite? } \\
\text { You are a teacher serious or a teacher funny? } \\
\text { Are you going to put up with the students? } \\
\text { Do you have any experience with children? }\end{array}$ \\
\hline Trabalho em equipe & $\begin{array}{l}\text { You like to teach in this school? } \\
\text { You are a very good teacher, do you want to } \\
\text { be hired? } \\
\text { What do you teach in this school? }\end{array}$ \\
\hline Compromisso social & $\begin{array}{l}\text { Do you like kids? } \\
\text { You like kids? } \\
\text { You have a daughter? } \\
\text { Do you live alone? } \\
\text { Do you like here? } \\
\text { You like books? } \\
\text { Do you like books? }\end{array}$ \\
\hline
\end{tabular}


Meu objetivo na segunda Atividade Pedagógica com Potencial Exploratório é refletir acerca das perguntas elaboradas pelos alunos participantes, assim como observar o que os alunos priorizariam se pudessem escolher um professor. É possível perceber que, ao elaborar as perguntas, os alunos participantes parecem entender o professor com um olhar multidimensional, uma vez que, levaram em consideração os aspectos pessoais, profissionais, pedagógicos, sociais e emocionais. Isto reforça meu entendimento de que os alunos são capazes de criar perguntas; interpretar o mundo a sua volta; e trazer seus saberes e suas perspectivas para a pesquisa.

Em uma segunda análise, chamou minha atenção o fato de que as perguntas formuladas poderiam ter sido feitas em uma entrevista real de emprego. As perguntas, elaboradas de forma espontânea na sala de aula, poderiam vir a fazer parte de entrevistas de trabalho autênticas, o que, para mim, revela maturidade reflexiva e o conhecimento intuitivo do gênero entrevista de trabalho por parte dos sete alunos.

Ainda refletindo acerca das perguntas, acredito que as mesmas revelam crenças individuais e coletivas acerca das características importantes que o professor de inglês precisa/deve possuir, na opinião desse grupo de alunos. Tais crenças são localizadas e situadas no contexto sócio-econômico-histórico-cultural de cada aluno. As crenças também se relacionam às experiências por eles vivenciadas fora da escola e no ambiente do Programa Bilíngue. Assim, as perguntas parecem mostrar crenças de que professor de inglês deve ter morado fora (cf. live in another place), falar inglês bem (cf. speak English very well), gostar de crianças (cf. like kids), entre outras crenças (ARAGÃO, 2019; BARCELOS, 2019). Tais crenças encontram-se presentes nas conversas exploratórias, gravadas e transcritas, discutidas no capítulo 7, mais adiante.

Retomo às Cinco Proposições (ALLWRIGHT; HANKS, 2009, p. 5-7), citadas no capítulo 2, com o objetivo de aprofundar minhas reflexões acerca das perguntas elaboradas pelos alunos. A primeira proposição refere-se à individualidade dos alunos ao gerenciar seus processos de aprendizagem, o que pode ser percebido pela forma como cada aluno usou o papel para realizar a atividade, a ordem escolhida para elencar as perguntas e os temas abordados. A segunda proposição diz respeito ao apoio mútuo e, apesar da subjetividade encontrada nas perguntas, os alunos estavam reunidos na sala de aula, com 
carteiras arrumadas em semicírculo em um contexto de aprendizagem que possibilita a interação social. A terceira e quarta proposições - aprendizes são capazes de levar sua aprendizagem a sério e tomar decisões independentemente estão interligadas e podem ser percebidas ao longo das atividades pela seriedade e autonomia de cada aluno participante. A quinta proposição diz respeito ao aprendiz capaz de se desenvolver como praticante de sua aprendizagem, ou seja, como agente e não como um indivíduo passivo no processo de ensino e aprendizagem (FREIRE, [1974]1979). Vale sempre frisar o nível de escolarização e a faixa etária de cada aluno participante.

As duas Atividades Pedagógicas com Potencial Exploratório mostram o quanto os alunos participantes são conhecedores do professor como pessoa e como profissional, não que seja possível separar os dois aspectos, o que já foi discutido no capítulo 4 (seção 4.1.5.). Observei que os sete alunos participantes parecem entender que o professor "tem um história de vida, é um ator social, tem emoções, um corpo, poderes, uma personalidade, uma cultura, ou mesmo culturas, e seus pensamentos e ações carregam as marcas dos contextos nos quais se inserem" (TARDIF, 2000, p. 15).

Neste capítulo, apresentei duas Atividades Pedagógicas com Potencial Exploratório e minhas reflexões baseadas na fundamentação teórica discutida anteriormente. No próximo capítulo, selecionei mais uma atividade realizada pelos alunos participantes, nas quais refletem sobre o lugar-escola. 


\title{
6 \\ O lugar-escola que habitamos como praticantes
}

Este capítulo tem como objetivo apresentar a escola pelo olhar dos sete alunos colaboradores através de suas descrições e percepções estéticas e afetivas, realizadas em duas Atividades Pedagógicas com Potencial Exploratório. $\mathrm{Na}$ primeira, os alunos se expressaram por meio de textos escritos e, na segunda, por desenhos, retratando o lugar-escola que habitam.

\section{1. \\ Que lugar-escola é esse?}

Em dois textos, Orr (2006a, 2006b, p. 114-136) discorre sobre a diferença entre habitar e residir num lugar. Para o autor, aquele que reside é um "ocupante temporário", que finca poucas raízes, ao passo que, aquele que habita "vive uma relação íntima com o lugar" e possui um "senso de cuidado e preservação das raízes", consequentemente, "os habitantes carregam as marcas do lugar". Orr (2006b, p. 125) propõe que

\begin{abstract}
Pelo menos uma vez na vida, todo homem (...) deveria dedicar-se a conhecer um determinado lugar, olhar para ele de tantos ângulos quanto lhe fosse possível, perguntar-se sobre ele e permanecer nele. Ele deveria se imaginar tocando-o com suas mãos a cada estação do ano e escutar os sons que ele produz. Ele deveria imaginar as criaturas que fazem parte dele e todos o movimentos quase imperceptíveis do vento. Ele deveria recordar o brilho do meio-dia e as cores do alvorecer e do crepúsculo - N. Scott Momaday, The Way to Rainy Mountain, p. 83.
\end{abstract}

Expresso minha afinidade com essa visão por entender a escola como um lugar que deve ser habitado pelos alunos, professores, coordenadores e todos os demais funcionários. De formas diferentes, considerando a contagem cronológica do tempo, é possível inferir que alguns habitam o lugar-escola por pouco tempo, enquanto outros por muito tempo, fincando raízes mais profundas.

O geólogo Tuan (2013, p. 11) sugere que "espaço e lugar são termos familiares que indicam experiências comuns", sendo que "o lugar é segurança e o espaço é liberdade". Para o autor, as pessoas constroem suas realidades e respondem ao espaço e ao lugar de maneiras diferentes, as quais são influenciadas pela cultura. Assim, o lugar pode significar mais do que espaço físico, pode dar 
noção de espaciosidade, que significa mais liberdade para agir ou para movimentar-se. Somente quando o espaço é inteiramente familiar, torna-se lugar. O tempo que demora para se conhecer um lugar é explicado pelo autor (TUAN, ibidem, p. 224) da seguinte maneira,

O conhecimento abstrato sobre um lugar pode ser adquirido em pouco tempo se é diligente $[\ldots]$ mas 'sentir' um lugar leva mais tempo: isso se faz de experiências, em sua maior parte fugazes e pouco dramáticas, repetidas dia após dia e ao longo dos anos. É uma mistura singular de visitas, sons e cheiros, uma harmonia ímpar de ritmos naturais e artificiais, como a hora do Sol nascer e se pôr, de trabalhar e brincar. Sentir um lugar é registrado pelos nossos músculos e ossos.

Sentir um lugar seria o mesmo que habitar. Em outras palavras, sentir-se enraizado demanda tempo, vivências, experiências e vínculos afetivos. No espaço físico onde realizo esta pesquisa, destaco o amor e a dedicação de duas pessoas comprometidas com a educação e com raízes totalmente fincadas no lugar. $\mathrm{Na}$ verdade, habitam o lugar mesmo antes da existência da escola como instituição de ensino; habitam desde que nasceram e até mesmo antes de nascer. As duas são mais que diretoras da escola; são as idealizadoras, fundadoras, professoras, administradoras, educadoras que vivem uma relação de afeto e pertencimento com o lugar-escola que habitam.

Tento imaginar quantas criaturas se banharam de sol e chuva em 50 anos: alunos, professores, coordenadores, responsáveis, funcionários da administração, da limpeza, da cozinha, da cantina, da portaria, da manutenção. É esse lugarescola que vai ficar na memória dos alunos que por lá já passaram e passam. Assim como na memória de todos os professores e professoras que por lá passaram e passam, pois "habitando, nos fazemos de certa maneira prisioneiros de um lugar, de uma geografia, de um tipo de clima, de regime de chuvas e ventos, de uma maneira de morar e de trabalhar e de fazer história". (BOFF, 1999, p. 77). Venho habitando esse lugar-escola há 17 anos.

Nesse lugar-escola, sem corredores e repleto de flores, existem carteiras e quadros, murais coloridos e computadores, recreios barulhentos e cheiro de comida, pátios, horta e jardins. Lá também habitam muitas árvores, trazendo sombra, som de pássaros e uma população enorme de insetos que entra na sala de aula 'roubando' a atenção dos alunos. Segundo contagem feitas pelos sete alunos participantes durante uma atividade pedagógica, a escola é habitada por 60/70 (?) 
árvores de diferentes tamanhos, entre elas, 8 mangueiras, 3 amendoeiras, 7 bananeiras, 2 pitangueiras, 1 goiabeira, 1 cajueiro, 1 cacaueiro, 1 mamoeiro, 1 caquizeiro, 1 jambeiro, 4 palmeiras, 1 videira, 1 figueira e outras árvores que os alunos não identificaram pelo nome. Que privilégio, em um bairro com tantos prédios, habitar um lugar-escola onde pode-se contar, sentir e tocar em tantas árvores. Nesse ambiente, a natureza faz parte da rotina de aprendizado e pode ser considerada material pedagógico.

Entendo que tão importante quanto o tempo que os alunos passam na sala de aula é o tempo que passam fora dela também. A oportunidade de "aventurar-se na natureza, desenvolver vínculos emocionais e estéticos com o mundo natural" (CAPRA, 2006a, p. 180) é essencial para o desenvolvimento da criança e a construção de sua identidade como cidadã do planeta. Olhando sob esse ângulo, o contato com a natureza requer o uso dos sentidos, o que possibilita perceber cheiros, cores, sons e texturas, além de inspirar a criatividade e a imaginação da criança (LOUV, 2005). Ao monitorar (cf. monitoring) enquanto os alunos participantes andavam pela escola contando as árvores, percebi o encantamento associado à sensação de pertencimento daqueles que vivem uma relação com o lugar, ou seja, que habitam. De acordo com Gleiser (2016, p. 102), "antes de estudar ciências na sala de aula, as crianças precisam vivenciar ao máximo as várias facetas do mundo natural: observar, para só então desenvolver uma compreensão conceitual". Na natureza, seja no quintal, no jardim ou na horta ou na floresta, a criança aprende a prestar atenção no mundo. Tocar, sentir o cheiro de uma árvore é diferente de ver gravuras no livro didático. Em contato com o mundo natural, a criança aprender usando os sentidos, vivenciando.

Além da construção física com paredes de tijolo, cimento, madeira, vidro, telhas, azulejos, etc., a escola é uma construção de emoções, afetos e memórias. A escola tem cor, som e cheiro. A escola tem alma; tem vida. Nesse lugar-escola onde habito e realizo a pesquisa, existe uma rede de vínculos afetivos entre pessoas que se relacionam profissionalmente ou não. Ressalto que durante as horas que passo na escola diariamente troco cumprimentos com todos, mas com poucos tenho tempo para conversar. Algumas pessoas não vejo com frequência, outras convivo mais de perto. Enfim, nesta teia de afetos, alguns laços se tornam mais substanciais, outros menos. Isso também acontece de acordo com o envolvimento com o trabalho em si. Meu lugar na escola está posicionado em um 
segmento e é deste lugar, desta perspectiva que vejo a escola. Assim, no universo da escola, eu habito um segmento, que é chamado de Programa Bilíngue. Neste segmento, dividido em educação infantil e ensino fundamental 1, habito o segundo. No total de nove turmas, duas são de minha responsabilidade - uma no turno da manhã e outra no turno da tarde. Participa desta pesquisa a turma do turno da tarde. Sendo este o lugar que habito.

Retomando a citação inicial, o que estou tentando fazer é aprofundar o entendimento acerca do lugar-escola e olhar para ele de tantos ângulos quanto for possível, entendendo que os ângulos possíveis estão relacionados ao aqui e agora de onde falo, às escolhas e aos recortes que faço. A escola que descrevo é como a entendo, como a vejo no momento. Junto com meu olhar, incluo o olhar dos sete alunos participantes.

\section{2. \\ O lugar-escola descrito pelos alunos participantes}

Ao invés de descrever a escola, achei relevante que os alunos participantes o fizessem com o intento de trazer a visão de cada um a respeito do espaço escolar com o qual se encontram familiarizados. No capítulo 4 (seção 4.3.1.), já havia mencionado pequenos trechos dos textos escritos por eles, para exemplificar as avaliações, por eles, realizadas nos campos do afeto, do julgamento e da apreciação.

Escolhi digitar os textos com algumas interferências nos aspectos ortográficos, mas não nos morfológicos ou sintáticos que, por ventura, ocorram de forma imprevista. Mantive a pontuação por eles utilizada. Usei colchetes para acrescentar palavras omitidas. Também deixei entre colchetes o nome da escola, que não aparece na dissertação. Isso posto, acho interessante observar como os alunos percebem e avaliam a escola que habitam no momento que realizaram a atividade.

A atividade, a seguir, foi escrita em uma folha branca tamanho A4. A proposta foi fazer uma caminhada pela escola e depois, então, na sala de aula, elaborar um texto descrevendo a escola para alguém que não a conhece. 


\section{Giovana}

[It] is very nice to spend [time] in a school with so many stories and heritages! My mom and my dad study here and me and my brother, we are studying here. Do you know that in the school we have like 75 trees! That is a big preservation! I love my school. It has library, bilíngue, sports court, cafeteria, etc. My favorite part in my school is the library. I love the books, the books are life for me.

\section{Theo}

Actually we have a great school, but I think that in the future they are going to reinaugurate [rebuilt] the library. I love my school, but I want upgrades in the future. And more sports and more people.

\section{Tito}

My school is medium[sized]. It has 3 schoolyards, 1 small sports court, 1 sports court and 62 trees. I love my school, I love the library and I like the schoolyard but my favorite part of my school is the sports court because I play soccer, basket[ball] and handball. In the total my school is the best school in the world. I love my school because all the teachers are very nice.

\section{Breno}

My school is the best because [it] has 2 schoolyards, sport court, a big library and a mini museum. My favorite part of my school is the sport court and the museum. My school has 73 trees in all the school. My favorite teacher is Pamela. I love my school because [it] has the best teachers and a lot of friends. In my opinion [it] is the best school ever.

\section{Daniel}

My school is very big. My school has many teachers. My favorite part of my school is the schoolyard, sports court, the library and the small sports court. My school has 73 trees. My favorite teacher is Pamela. In my school I do not like the classrooms. I like to study in my school. The teachers are nice. 


\section{Gael}

The name of my school is [...], it is very beautiful and big, it has sports court, 3 schoolyards, water fountains, library, small sports court etc. It has very good teachers and classrooms. In my school you have to use [wear] uniforms.

The thing that I like in my school is the computer lab, the Physical Education [classes] and the Bilingue.

\section{Bruna}

School is very important for me and for everybody. [It] has sports court, schoolyard, library, cafeteria, water fountain, vegetable garden, etc.

They have very important stories.

My favorite part in my school is the library and the cafeteria. [It] is very difficult to choose a place. I love my school.

Em suas descrições, os alunos mostram conhecer a geografia do lugar e expressam seus sentimentos e afetos pela escola fazendo uso dos verbos love e like/do not like e dos adjetivos big, beautiful, important, nice, good, great e do superlativo the best. Como acredito que criar vínculos com um lugar exige tempo e paciência (ORR, 2006b, p. 131-132), considero relevante mencionar que quatro dos alunos participantes passam sete horas de seu dia na escola, enquanto três alunos, em horário integral, passam dez horas. Dessa forma, eles, assim como eu, habitam este lugar-escola e é possível sentirmo-nos "parte de um lugar porque esse lugar é também parte de nós”, conforme propõe Reis $(2018$, p. 53) em sua tese de doutorado, na qual busca entender a forma como seus alunos compreendem sua escola.

Dois alunos mencionaram a sala de aula em suas descrições. Gael escreveu que a escola tem bons professores e salas de aula (It has very good teachers and classrooms) ao passo que Daniel, apesar de gostar da escola, escreveu que não gosta das salas de aula (In my school I do not like the classrooms). Os outros alunos não mencionam as salas de aula em suas descrições. No geral, seus olhares foram dirigidos para escola como um todo. Desse modo, interpreto que, para eles, o que a escola representa vai muito além do que acontece na sala de aula. Talvez, o que está fora da sala pode ser mais interessante como a quadra de esportes, o refeitório, os pátios onde brincam, as árvores, a biblioteca onde ouvem histórias. 
Para os alunos participantes, a escola é lugar de estar, fazer amigos, brincar, praticar esportes, descansar, almoçar e, também, de estudar, ensinar e aprender.

Em consonância com hooks (2013), Palmer (2012), Capra (2006a) e Freire ([1996]2018a; [1981]2018b), entendo a escola como um organismo vivo, dinâmico, sistêmico, não linear, com múltiplos níveis, diversificado, criativo, holístico, onde os aspectos afetivo, ético, pedagógico e social caminham juntos no processo de (co) (re) (des) construções do ensino e da aprendizagem. A escola (MILLER et al., 2008, p. 155)

é (ou deveria ser) um reflexo desta vida, o lugar onde se aceita, incentiva e trabalha para entender a complexidade dos questionamentos e das perguntas, a incompletude e a incerteza de suas respostas. Para os praticantes de Prática Exploratória, a escola não deveria ser o lugar das respostas, e sim o lugar da vida.

A escola é, sim, o lugar da vida, de afetos e emoções, de criação e beleza, de dúvidas e curiosidade, de muitas perguntas e respostas. De possibilidades infinitas. De construções. De conexões. De ensinos e aprendizagens. De letramentos (ROJO, 2009, 2015).

\section{3. O quintal da escola}

Antes de descrever a terceira Atividade Pedagógica com Potencial Exploratório, acho relevante promover reflexões acerca do que chamo de o quintal da escola.

O quintal da escola inclui pátios de areia, árvores frutíferas, horta, cantos e recantos com pisos de pedra ou grama sintética, jardins, canteiros, vasos de plantas e muitas flores. Uma raridade haver uma lugar assim em um bairro que desperta interesses imobiliários diversos. Manter-se firme ao sonho que surgiu em 1969 parece algo que merece ser admirado. Na trajetória de 50 anos, o entorno mudou. No início, na década de 70 , a escola encontrava-se rodeada por três grandes escolas religiosas tradicionais e por escolas da rede pública que ofereciam educação de qualidade. Com o passar dos anos, algumas coisas foram mudando. Outras instituições foram surgindo e hoje existem várias administradas por gestores, que entendem educação como negócio e alunos como clientes. Mas, a 
escola com quintal continua apaixonada por educação e chamando os alunos por seus nomes.

A aparência de quintal não esconde a gama de atividades pedagógicas que lá acontecem diariamente, mas oferecem um encantamento e uma sensação de habitar um grande quintal onde afetos e memórias se entrelaçam. Bedran (2010, p. 100) cita sua mãe, Walda Bedran, para enaltecer que "um quintal é o primeiro palco que uma criança pisa. Pode ser uma área ou um pequeno espaço qualquer onde ela se exteriorizará, largará sua imaginação e desenvolverá sua criatividade". Nesse sentido, entendo que o quintal da escola é o palco que os alunos escolheram desenhar quando propus a terceira atividade, descrita na próxima seção.

No quintal, acontece o recreio. O recreio mostra o clima e a cultura da escola. É a hora esperada para correr, brincar, explorar, conviver, vivenciar experiências significativas, interagir com o outro. Um pouco limitados nos dias de chuva, mas amplos e com múltiplas opções de espaços nos outros dias. Espaços, aos quais os alunos se referem nas atividades apresentadas, sejam em seus textos, seus desenhos assim como durante as conversas exploratórias registradas no capítulo 7. Em relação aos desenhos dos alunos, percebidos por mim como forma de expressão artística, me alinho com Bedran (ibidem, p. 78),

[...] a produção artística envolve o aluno numa experiência individual, única, verdadeira e isenta de competitividade, pois a única preocupação nela presente é a expressão do eco da narrativa em sua alma. Ao mesmo tempo, a experiência o insere no coletivo, pois durante o processo de observação das produções dos colegas a criança realiza uma livre e transformadora apreciação estética. São visões diferentes de uma mesma situação, são lugares diferentes de olhar e sentir, são formas e sentidos que se entrelaçam e tecem um novo tecido.

Em consonância com a autora citada, entendo os desenhos dos sete alunos participantes como "expressão do eco da narrativa em sua alma". Ao escolher o mesmo pátio, cada aluno apresentou "visões diferentes" de um pedaço do quintal e expressou em seus desenhos afetos pelo quintal da escola que habitam.

\section{4 . \\ O desenho como forma de expressão}

A terceira Atividade Pedagógica com Potencial Exploratório foi proposta da seguinte maneira: os alunos teriam que pensar em um lugar da escola que fosse 
especial para eles; teriam que ir ao local e desenhar. Assim, levaram o material e se espalharam pela escola. Passaram um tempo observando e desenhando ao ar livre. Ao retornar para sala de aula, deram continuidade pintando o desenho. Depois, escreveram um texto justificando suas escolhas. Sendo assim, nesta atividade, os alunos combinaram desenho e texto escrito.

Uma característica que observo no grupo é o gosto pelo desenho e outras formas de expressão artística. Como aponta Saramago (1998), “espero que não esteja esquecido de que a humanidade começou a pintar muito antes de saber escrever, [...] quem não pode escrever, pinta, ou desenha, é o que fazem as crianças'. Nesse viés, destaco que desenhar pode ser uma forma de entender a vida na sala de aula. Desenhar pode também ser entendido tanto como uma forma de comunicação e expressão de sentimentos, ideias, pensamentos assim como a representação gráfica de pessoas, animais, plantas, fatos, objetos e lugares. $\mathrm{O}$ ato de desenhar pode comunicar a identidade pessoal, social e cultural de cada aluno. Mais ainda, "o desenho habita a fronteira entre a ideia e a realidade. [...] Desenhar fica no limite entre o imaginar e o fazer, entre os pensamentos e os sentimentos" (ISODA, 2013, p. 18). Assim, o desenho dos alunos aqui apresentados pode ser uma forma de expressar "entendimentos mais profundos".

A relação da humanidade com o desenho é antiga, podendo-se dizer que "a história foi e é contada a partir de desenhos" (PEREIRA, 2015, p. 17). No ambiente escolar, o ato de desenhar é uma das primeiras atividades pedagógicas na qual a criança se envolve. Desenhar requer coordenação motora e visual; organização do pensamento; imaginação, percepção e reflexão; criatividade e sensibilidade. Para Isoda (2013, p. 18-19), “desenhar é ação e ideia. É meio, processo e fim. Tem múltiplos usos, manifestações e aplicações. [...] É um processo não linear, não há uma ordem cronológica entre pensar, riscar, observar, corrigir, idealizar, etc." Acredito que esse pensamento pode ser completado com as palavras de Derdyk (1989, p. 46), que “o desenho é exercício de inteligência humana".

É possível afirmar que minha motivação em integrar os desenhos dos alunos participantes ao texto da dissertação foi minha crença de que cada aluno aprende, percebe, compreende e reflete de maneiras diferentes e, consequentemente, se expressa, questiona, duvida e cria também de formas variadas. No Programa Bilíngue, entendemos o desenho produzido pelas crianças 
como forma de expressão, como leitura do mundo, como manifestação criativa e como linguagem. Assim, a seguir, apresento os desenhos e os textos dos alunos.

\section{5.}

\section{Terceira Atividade Pedagógica com Potencial Exploratório}

A terceira Atividade Pedagógica com Potencial Exploratório foi realizada após o horário do almoço, que é seguido de um momento livre para brincadeiras. Ao retornar à sala de aula, propus a atividade, a qual foi aceita com entusiasmo. A primeira parte foi escolher um lugar da escola para desenhar. Para isso, entreguei uma folha branca, previamente recortada por mim, do tamanho aproximado de $15 \times 20 \mathrm{~cm}$, em papel com espessura de cartolina.

Inicialmente, os alunos andaram pelos pátios, observando e examinando na tentativa de decidir ou escolher um lugar. A escola possui três pátios grandes - o pátio da frente, o pátio do meio e o pátio das galinhas - os quais os alunos mencionam no capítulo 7 e outros pátios menores. Ressalto que o terceiro recebeu este nome há muitos anos quando havia um galinheiro e muitas galinhas. Naquela época, os alunos observavam as aves, os ovos nos ninhos, os pintinhos nascendo e crescendo. Até que veio a exigência para sua retirada, fato que causou muita tristeza nos alunos. Porém, o nome do pátio permaneceu e os alunos que estão na escola hoje nem imaginam o que foi conviver, brincar e admirar o pátio das galinhas, quando elas também habitavam o quintal da escola.

Após andar pelos pátios, os sete alunos escolheram o pátio das galinhas e passaram um tempo desenhando. Quando retornamos à sala de aula, coloriram os desenhos. Propus, então, a segunda tarefa que foi escrever um texto sobre o lugar em uma folha de papel folha A4 na cor azul.

A seguir, apresento o contexto de como os desenhos foram elaborados pelos alunos, minhas observações realizadas durante a atividade (cf. monitoring), os desenhos finalizados e os textos dos alunos, os quais foram digitados com algumas interferências nos aspectos ortográficos, para facilitar a leitura. 


\section{Giovana}

Para desenhar, Giovana sentou-se no chão de areia, em uma área do pátio e escolheu um canto com plantas. $\mathrm{O}$ banco desenhado não fica no local que ela escolheu; foi criação dela. Quando o desenho ficou pronto, Giovana disse que havia "misturado duas cenas em sua cabeça". Segundo Pillar (1996, p. 37), a criança "não desenha o que vê nos objetos, mas o que suas estruturas mentais lhe possibilitam que veja". A autora acrescenta que, "em lugar de encontrar o mundo diretamente, a criança o interpreta, desta forma o conhecimento não resulta da relação direta da criança com os objetos, mas sua interpretação e representação". Foi desta forma que Giovana interpretou o que viu no pátio.

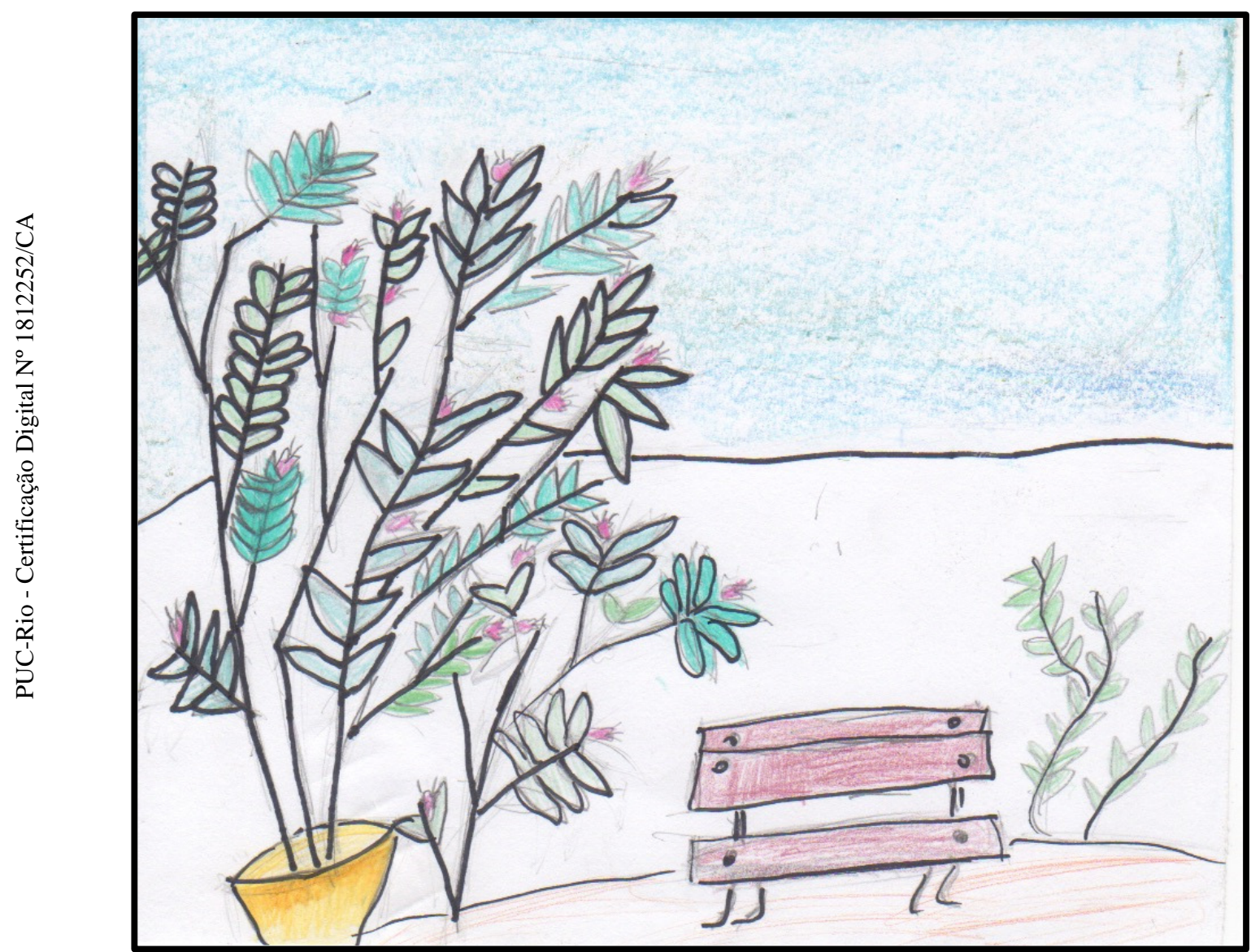

\section{Giovana sobre seu desenho}

I chose that place because we can see nature there and the evolution of the humans. It's beautiful to see a very calm place and a blue sky. I like to stay there with my friends and [it] isn't just because I stay with my friends. That is my lovely schoolyard. 


\section{Theo}

Observei que Theo andou pela horta, sentou-se num canteiro, tocou em algumas plantas. Escolheu desenhar um vaso de flores que se encontrava perto da cerca de madeira que separa a horta do pátio das galinhas. Quando o esboço do desenho estava quase pronto, juntou-se aos colegas subindo na casa da árvore, onde é possível ter uma visão superior da horta. Esta experiência mostra que seu desenho "não é mera cópia, reprodução mecânica do original” (DERDYK, 1989, p. 112). Para a autora, o desenho "é sempre uma interpretação, elaborando correspondências, relacionando, simbolizando, significando, atribuindo novas configurações ao original. $\mathrm{O}$ desenho traduz uma visão porque traduz um pensamento, revela um conceito".

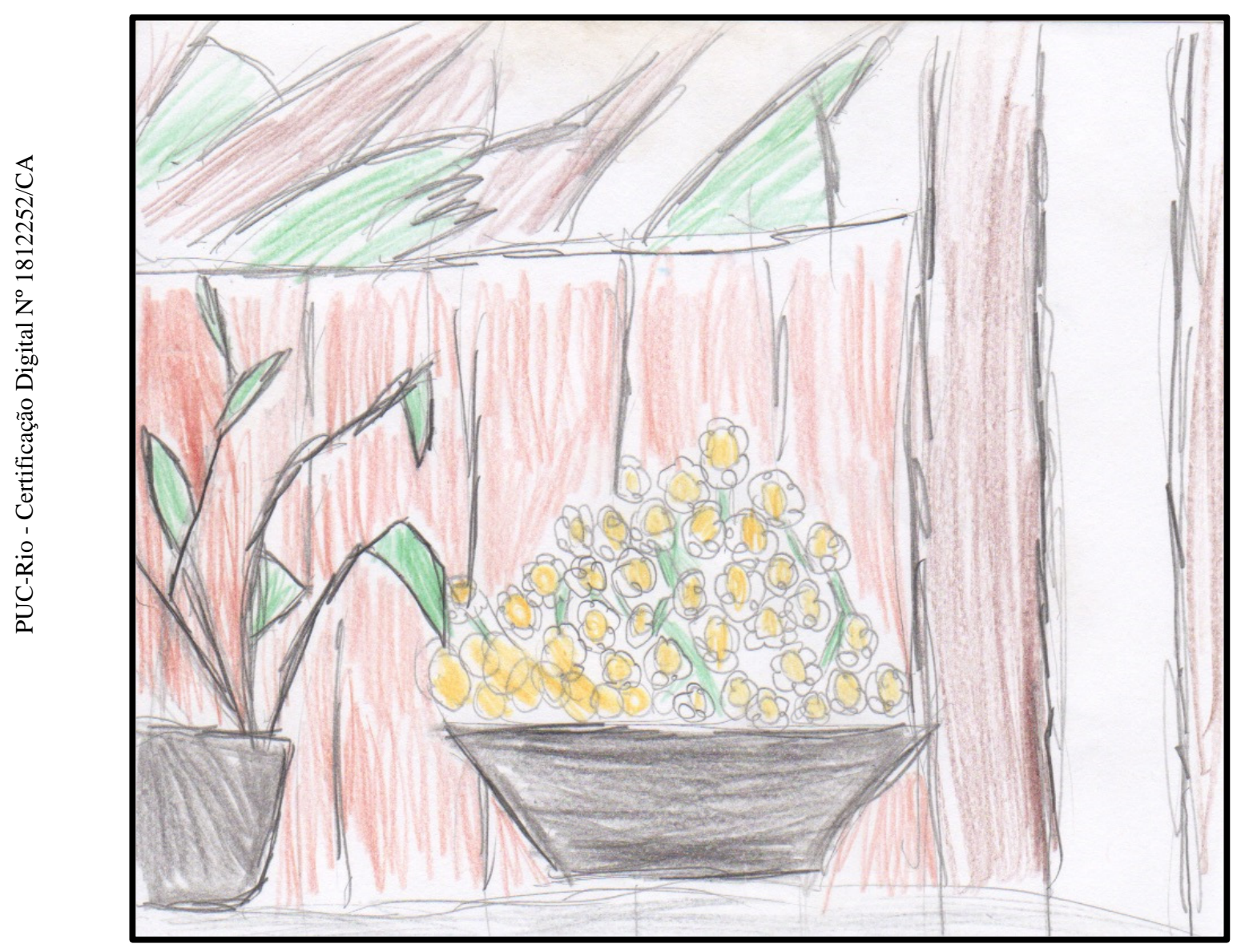

\section{Theo sobre seu desenho}

I chose this place because it's in the vegetable garden. There are daisies, a beautiful landscape and other plants. I like this place because I like daisies, plants and it's in my school. 


\section{Tito}

Tito estava sentado em uma mesa de madeira, tipo mesa de piquenique, localizada embaixo de uma das mangueiras, no pátio da galinhas, quando desenhou a casa da árvore e seus colegas. Os três meninos são Theo, Gael e Breno, que naquele momento estavam trabalhando em seus desenhos.

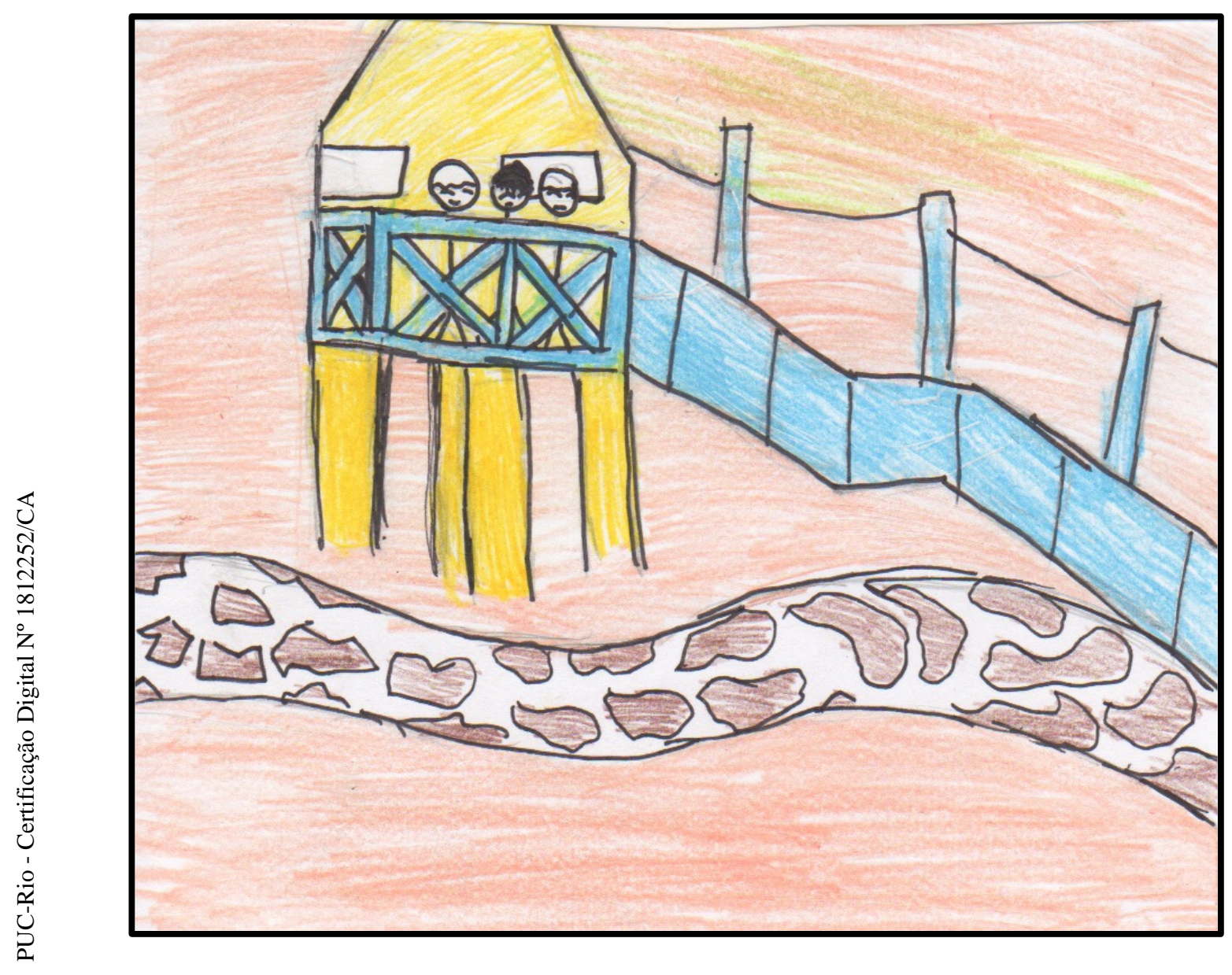

\section{Tito sobre seu desenho}

I chose this place because there is a path of rocks and sand. There is a colorful and beautiful tree house, I run and play volleyball and soccer. This place is the schoolyard and it is in my school. I like it because there is a lot of space to play. 


\section{Breno}

Breno escolheu subir na casa da árvore. De lá, desenhou o que avistou naquele momento, como uma foto. Os dois meninos na cena são Daniel, à esquerda, sentado no chão de frente para a janela que escolheu desenhar e Tito, à direita, sentado na mesa de piquenique. Breno disse que não conseguiu desenhar Tito segurando o material de desenho em suas mãos, o que sugere sua preocupação em captar os detalhes da cena observada.

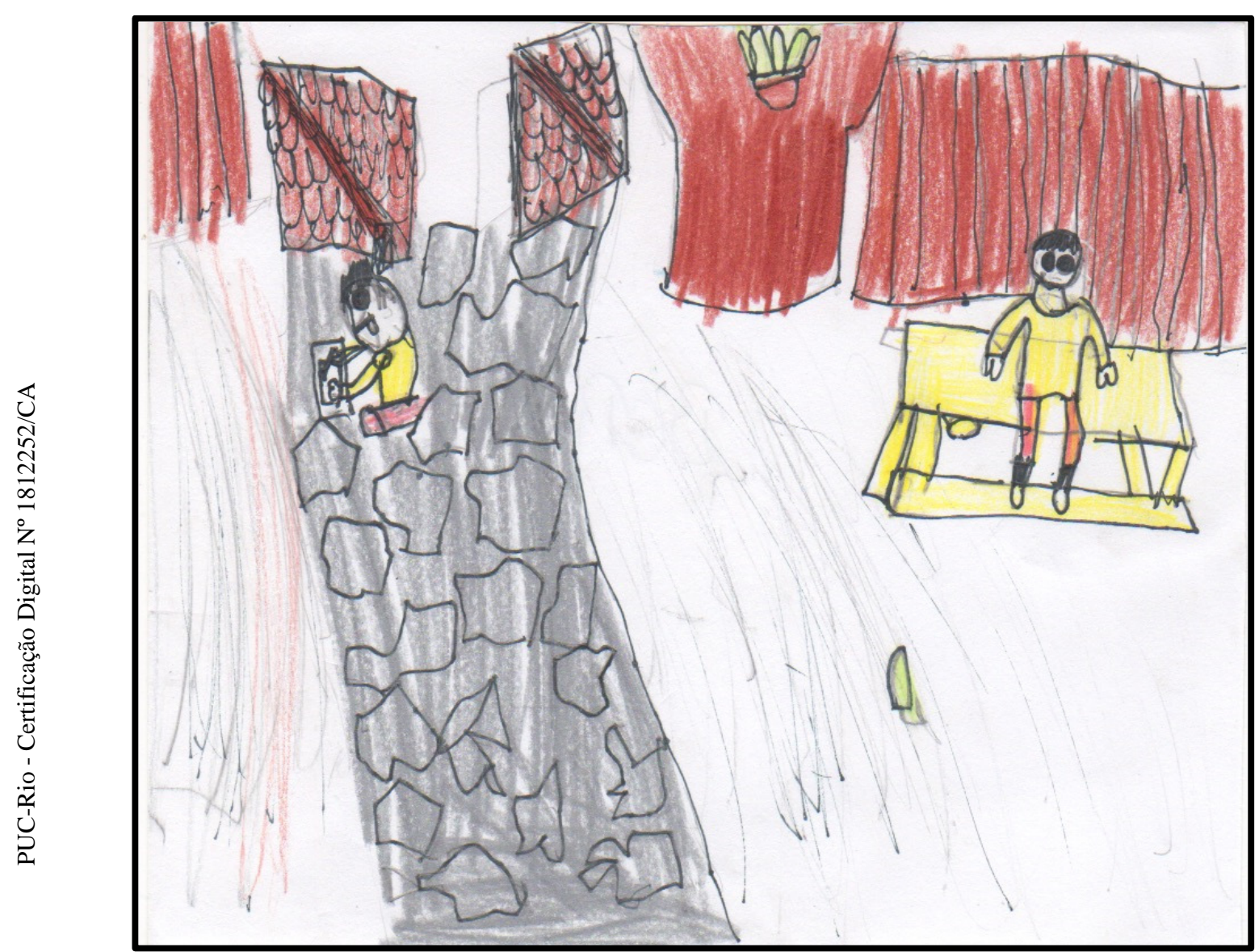

\section{Breno sobre seu desenho}

I chose this place because this place has trees, a lot of sand and a tree house. I like this place because it has beautiful flowers. I think this place is beautiful because there are animals as birds and monkeys, a mini museum, a very big schoolyard and a tree house. This place is in my schoolyard. 


\section{Daniel}

Daniel foi desenhado por Breno e Gael, que estavam na casa da árvore. Para elaborar seu desenho, sentou-se no chão, na entrada do pátio das galinhas, de frente para uma parede com janela de correr de vidro, com madeira pintada de vermelho. Destaco que, em todas as soleiras das janelas da escola, encontramos vasos de flores de diversas cores, um ao lado do outro. Observei que Daniel desenhou uma parte da janela e um vaso de flores como se ele tivesse ampliado o foco de sua máquina fotográfica para captar detalhes da cena escolhida. Nas palavras de Derdyk (1989, p. 24), "a visão parcial de um objeto nos revelará um conhecimento parcial desse mesmo objeto". Nesse sentido, apesar de estar em um ambiente amplo como o pátio, Daniel escolheu mostrar os detalhes que chamaram sua atenção naquele momento.

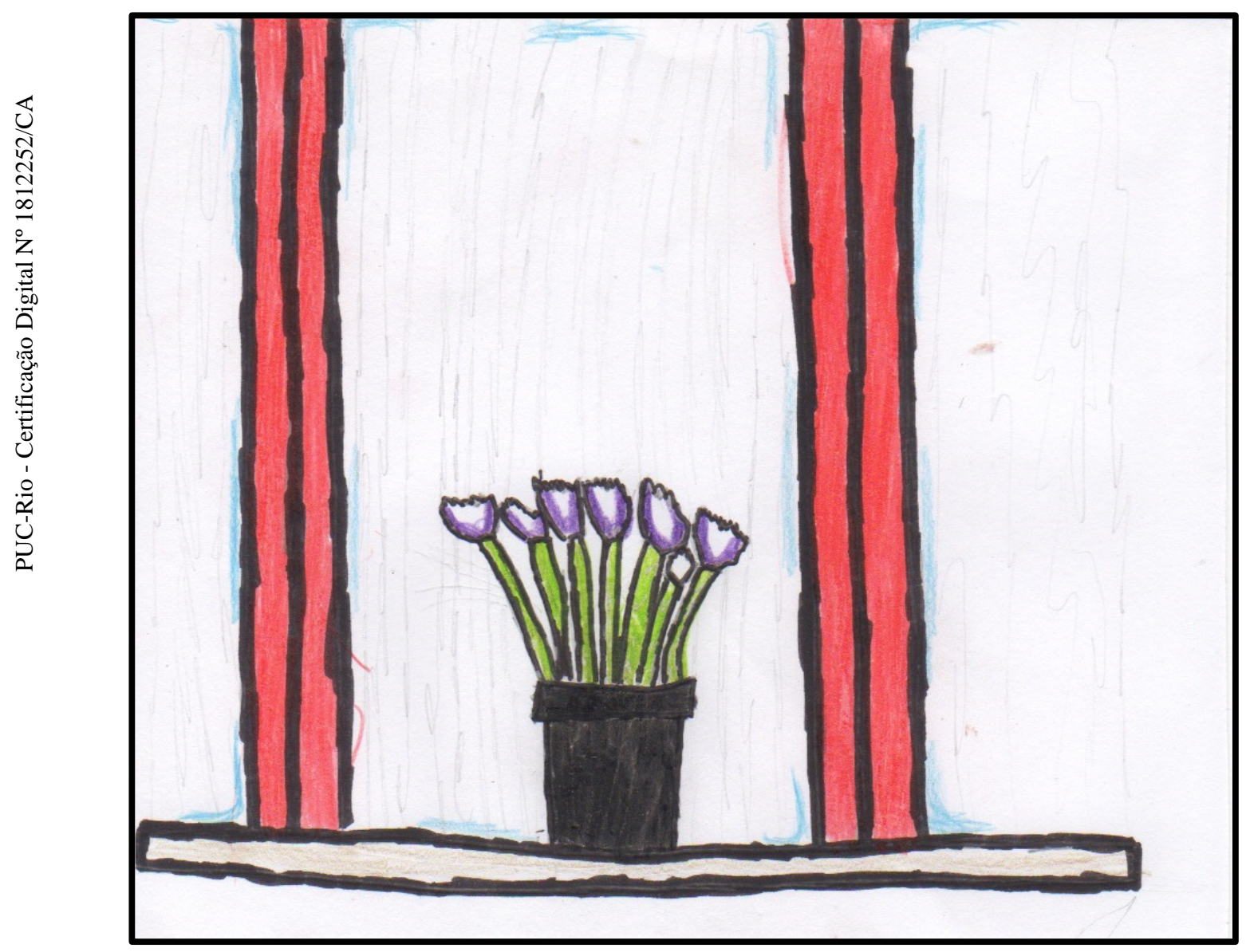

\section{Daniel sobre seu desenho}

I chose this place because I love this flower and [it] is very beautiful. This place is located in the schoolyard. 


\section{Gael}

Para compor seu desenho, Gael subiu na casa da árvore e registrou em sua cena na qual Daniel sentado no chão à esquerda e Tito sentado na mesa de piquenique à direita, trabalhavam em seus desenhos. De acordo com Derdyk (2012, p. 10), “toda paisagem contém seus inumeráveis pontos de vista, mas somente algumas regiões são absolutamente privilegiadas”. Sendo assim, é possível inferir que Gael escolheu um lugar de onde pudesse observar amplamente a paisagem.

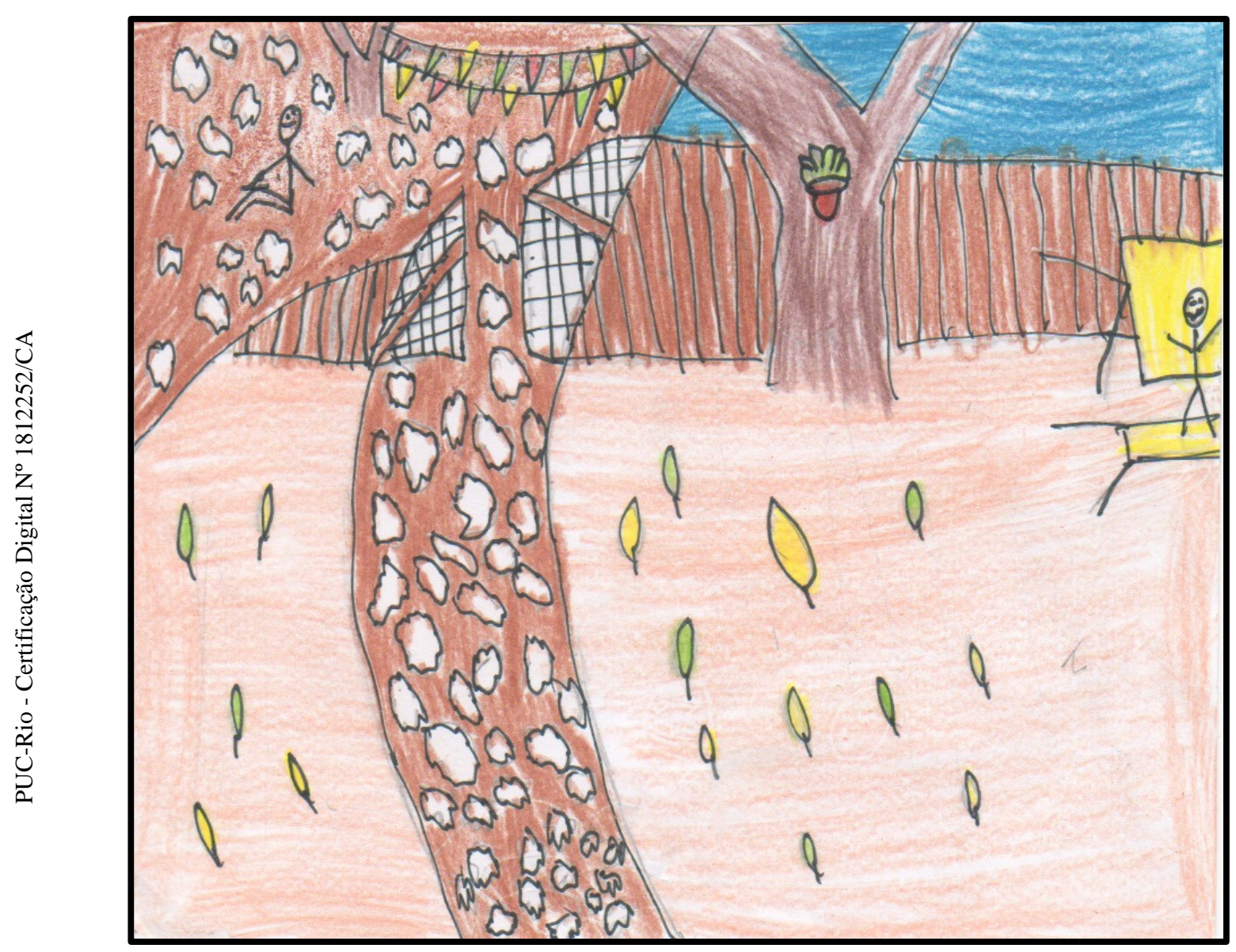

\section{Gael sobre seu desenho}

I draw this place because it is very beautiful and I have very good memories of this place when I played football with my friends last year. This is beautiful because it has trees and plants, animals as birds and butterflies. This place is a schoolyard. 


\section{Bruna}

Bruna escolheu uma obra de arte feita a partir de uma folha de flandres ou zinco pintado que fica na parede externa de uma sala de aula. Vale ressaltar que existem outras bandeiras do Brasil espalhadas pela escola feitas de madeira, tecido e outros materiais. Bruna relatou que escolheu esta bandeira porque a folha verde da bananeira faz parte da natureza e que gostou das flores amarelas. Assim como Daniel, Bruna focou seu olhar para os detalhes de um único objeto.

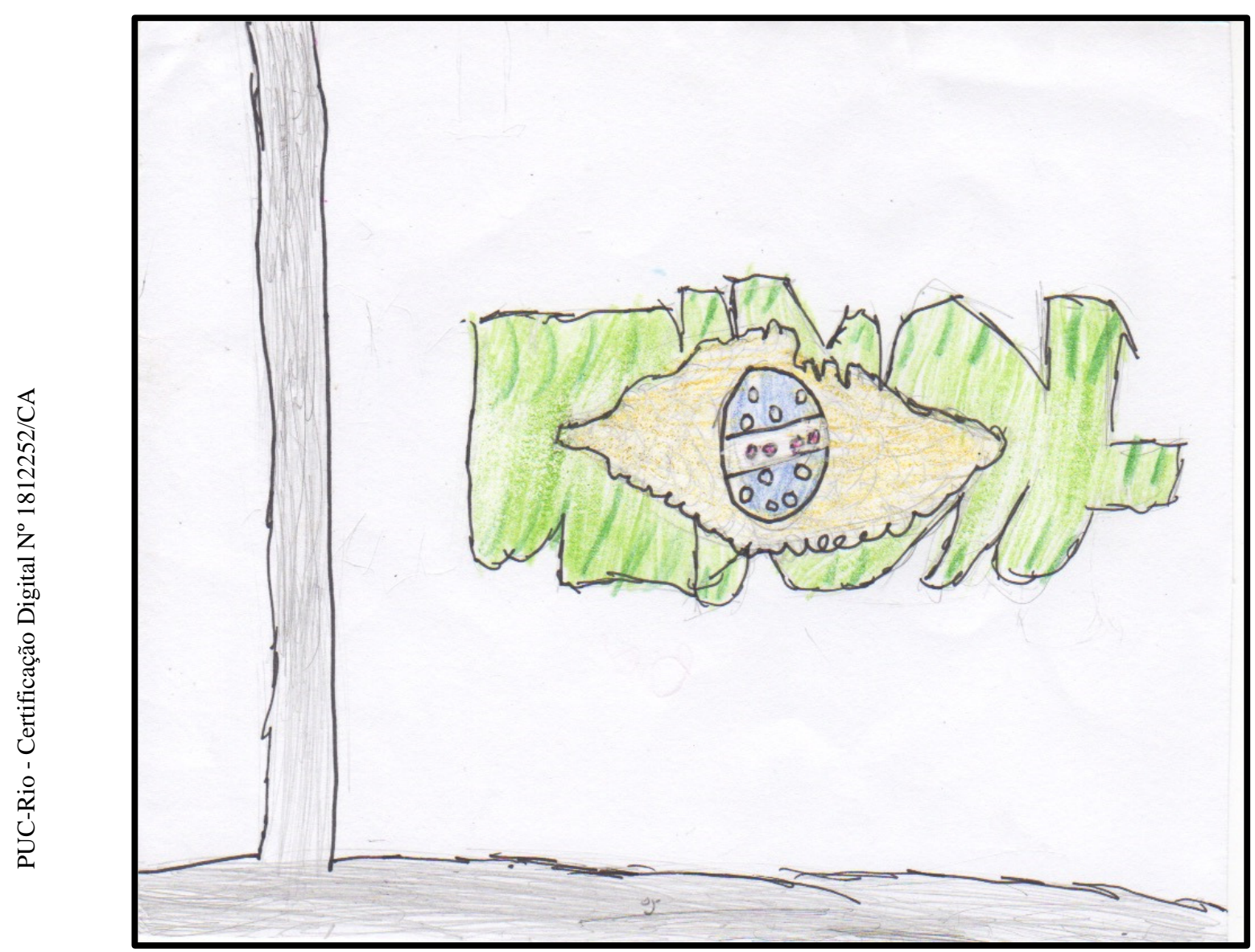

\section{Bruna sobre seu desenho}

I like this place because of the flag of Brazil, it's the symbol of the country. Very important in my life because in my opinion all people should love the flag of [their] country. This picture is very important for me and everybody. This picture is in my school. 


\section{6. Reflexões}

Acho que os desenhos e textos apresentados mostram que os alunos têm fortes vínculos afetivos com o espaço físico da escola. Isso ficou evidenciado tanto por suas escolhas em relação ao lugar que desenharam assim como por suas escolhas lexicais, nos textos. Entendo que os desenhos e os textos parecem indicar que "vivem uma relação íntima com o lugar", "possuem um senso de cuidado", e também “carregam as marcas do lugar" (CAPRA, 2006a). Acredito que cada escolha carrega, também, as crenças, as atitudes e os afetos de cada aluno.

Em relação às escolhas lexicais realizadas nos textos escritos, o adjetivo beautiful foi usado por seis alunos para se referir ao espaço escolhido e registrado no desenho, o que me permite entender a importância dos "vínculos emocionais e estéticos" (CAPRA, ibidem) que o contato com a natureza proporcionam à criança. Também pode ser destacado o fato dos alunos mencionarem flores, pássaros, árvores, insetos, o que no meu entendimento mostra familiaridade com a natureza que os cercam.

Observei que, diante da proposta de escolher um lugar especial, todos foram para fora da sala de aula e aproveitaram a proximidade com a natureza que a escola proporciona. Até mesmo a bandeira que Bruna desenhou nos remete a diversidade da flora brasileira. Se eu tivesse também desenhado um lugar na escola, teria escolhido a entrada pelo pátio da frente. Pelo simples motivo que, mesmo, depois de tantos anos, chego, diariamente, encantada com as orquídeas colorindo os troncos das árvores e os tons de verde contrastando com as construções, nas quais sobressaem as cores branca, vermelha e amarela. $\mathrm{Na}$ verdade, são muitos lugares de afetos e, valendo-me das palavras do Gael, I have very good memories of this place, posso afirmar que eu também coleciono boas memórias desse lugar-escola. Assim sendo, acredito que os textos dos alunos complementam seus desenhos. E entendo seus desenhos como fotografias dos seus afetos pelo lugar-escola que habitam.

Recapitulando, neste capítulo apresentei a terceira Atividade Pedagógica com Potencial Exploratório. No próximo, faço recortes da transcrição das conversas individuais que tive com os sete alunos participantes, selecionando trechos que se relacionam com os seguintes temas: o professor de inglês, o lugar- 
escola e a participação na pesquisa. Acho importante frisar que para a análise da língua em uma interação real de uso é necessário levar em consideração o contexto em que a mesma acontece e, especificamente, nessa pesquisa, a idade e a escolarização de cada aluno são relevantes para promover entendimentos e reflexões.

A seguir, passaremos para o capítulo das análises do discurso gerado durante as conversas gravadas em áudio. 


\section{7}

\section{Análise das conversas exploratórias}

Neste capítulo, tenho como objetivo analisar discursivamente trechos das conversas exploratórias entre os alunos participantes e eu a respeito das Atividades Pedagógicas com Potencial Exploratório, levando em consideração as conceituações e teorias apresentadas nos capítulos anteriores. Uma análise linguística-discursiva no contexto da pesquisa do praticante permite um olhar mais apurado que pode levar a maiores entendimentos das questões refletidas pelos alunos participantes e por mim.

\section{1.}

\section{Análise dos dados}

Uma pesquisa só pode ser compreendida quando socialmente e localmente situada. Portanto, acho importante acrescentar que, nas avaliações realizadas pelos alunos, deve-se levar em consideração "a relação dialética entre texto e contexto" (VIAN JR., 2009, p. 123), ou seja, crianças entre 10 e 11 anos de idade conversando comigo, professora-pesquisadora, em uma situação de mais formalidade e com a presença de um celular-gravador. Assim como para mim os desenhos dos alunos são como fotografias do lugar por eles escolhidos, as transcrições de nossas conversas exploratórias revelam seus pensamentos e ideias no momento da gravação.

Não me refiro às conversas gravadas como entrevistas, mas sim como conversas exploratórias por considerá-las uma atividade pedagógica. Minha intenção durante as conversas foi abordar três temas: o professor de inglês, o lugar-escola e a participação na pesquisa, porém sem um roteiro de perguntas previamente estruturadas. Diferentemente das Atividades Pedagógicas com Potencial Exploratório, os alunos participantes se expressaram em português pois o objetivo das conversas exploratórias era a reflexão acerca da atividades que haviam realizado e da participação na pesquisa.

As interações gravadas em áudio aconteceram na escola, no horário da aula do Programa Bilíngue. Enquanto a professora Tânia (nome fictício) conduzia a aula com a turma, chamei os alunos para conversarmos individualmente em uma outra sala. Durante as conversas, as Atividades Pedagógicas com Potencial 
Exploratório permaneceram em cima da mesa para que os alunos pudessem consultar ou manusear, caso assim o desejassem. Por questões dos horário de entrada, saída e almoço, da disponibilidade da professora Tânia, e da eventual falta dos alunos, as conversas exploratórias foram acontecendo no período de um mês. Giovana, Theo e Bruna participaram de uma única conversa, com duração de aproximadamente 15 minutos cada uma, em dias diferentes. Tito, Daniel e Gael participaram de três conversas em três dias, enquanto Breno participou de duas conversas em dois dias. Como já foi mencionado, o objetivo dessa organização foi não alterar as atividades escolares para que os alunos não ficassem muito tempo separados da turma.

As conversas exploratórias aconteceram em torno de três temas centrais já mencionados anteriormente. Para a análise linguística-discursiva, selecionei trechos das conversas, nos quais os temas foram abordados e refletidos pelos alunos participantes. Acredito que uma análise detalhada do discurso dos sete alunos participantes pode me ajudar a entender melhor minha prática de sala de aula. Com foco na avaliação, tendo o aporte do Sistema de Avaliatividade MARTIN; WHITE, 2005; NÓBREGA, 2009), inscrito no arcabouço teórico da Linguística Sistêmico-Funcional (HALLIDAY, 1994), a análise micro do discurso pode revelar através das escolhas léxico-gramaticais dos alunos como os mesmos avaliam os temas abordados nas atividades no âmbito do afeto, do julgamento e da apreciação, o que contribui para o enriquecimento da pesquisa do praticante.

Passo, então, para a apresentação dos fragmentos selecionados do material transcrito das conversas exploratórias. Os excertos serão seguidos de reflexões e análises fundamentadas nas teorias já discutidas nos capítulos anteriores.

\section{2.}

\section{Nossas conversas sobre o professor de inglês}

Nos excertos selecionados, os alunos conversam comigo a respeito da primeira e da segunda Atividade Pedagógica com Potencial Exploratório, apresentadas no capítulo 5, nas quais o tema abordado foi o professor de inglês no contexto do Programa Bilíngue da escola.

\section{Excerto 1 - Giovana - "experiência"}

\begin{tabular}{|l|l|lllll}
\hline 19 & Mara & é: uma pergunta de entrevista mas o que \\
\hline
\end{tabular}




\begin{tabular}{|c|c|c|}
\hline 20 & & mais você perguntou \\
\hline 21 & Giovana & do you work in another school? \\
\hline $\begin{array}{l}22 \\
23\end{array}$ & Mara & $\begin{array}{l}\text { por que você acha que é importante essa } \\
\text { pergunta? }\end{array}$ \\
\hline $\begin{array}{l}24 \\
25 \\
26 \\
27\end{array}$ & Giovana & $\begin{array}{l}\text { porque se a pessoa já tivesse trabalhado ou } \\
\text { trabalha em outra escola além dessa seria } \\
\text { um horário <diferente> por exemplo é: e } \\
\text { também ela já teria: <alguma> experiência } \\
\text { né } \uparrow\end{array}$ \\
\hline 28 & Mara & aham em outra escola né $\uparrow$ \\
\hline 29 & Giovana & [em outra escola] \\
\hline 30 & Mara & qual a outra pergunta que você fez? \\
\hline $\begin{array}{l}31 \\
32\end{array}$ & Giovana & $\begin{array}{l}\text { ah vamos ver do you have experience with } \\
\text { children? }\end{array}$ \\
\hline 33 & Mara & isso é importante? \\
\hline $\begin{array}{l}34 \\
35 \\
36 \\
\end{array}$ & Giovana & $\begin{array}{l}\text { isso é importante imagina se a pessoa não } \\
\text { tem nenhuma experiência com a criança né } \\
\text { <isso serial um: problema ((risos)) }\end{array}$ \\
\hline 37 & Mara & e qual outra pergunta você fez? \\
\hline $\begin{array}{l}38 \\
39\end{array}$ & Giovana & $\begin{array}{l}\text { mmm vamos ver did you live in another } \\
\text { country? }\end{array}$ \\
\hline 40 & Mara & então por que você fez essa pergunta? \\
\hline $\begin{array}{l}41 \\
42 \\
43 \\
44 \\
45\end{array}$ & Giovana & $\begin{array}{l}\text { porque a pessoa né poderia saber outra } \\
\text { língua isso seria muito interessante teria } \\
\text { é: saberia por exemplo o: : como é: o como } \\
\text { é o outro lugar teria tido né } \uparrow \text { a } \\
\text { experiência de um lugar diferente }\end{array}$ \\
\hline $\begin{array}{l}46 \\
47\end{array}$ & Mara & $\begin{array}{l}{ }^{\circ} \text { humhum }{ }^{\circ} \text { e você colocou mais uma pergunta } \\
\text { qual foi? }\end{array}$ \\
\hline 48 & Giovana & how many years do you have ((risos)) \\
\hline 49 & Mara & ${ }^{\circ}$ não ${ }^{\circ}$ how many years $=$ \\
\hline 50 & Giovana & [how many years did you study english?] \\
\hline 51 & Mara & isso é importante? \\
\hline $\begin{array}{l}52 \\
53\end{array}$ & Giovana & $\begin{array}{l}\text { sim porque né tem um certo tempo né que } \\
\text { você deveria estudar inglês ((risos)) }\end{array}$ \\
\hline $\begin{array}{l}54 \\
55\end{array}$ & Mara & $\begin{array}{l}\text { quanto tempo que você acha que a pessoa } \\
\text { deveri= }\end{array}$ \\
\hline 56 & Giovana & [uns dez anos] \\
\hline $\begin{array}{l}57 \\
58\end{array}$ & Mara & $\begin{array}{ll}\text { dez anos? e essa última pergunta que você } \\
\text { fez ((risos)) ah pode falar }\end{array}$ \\
\hline 59 & Giovana & não: : ( (risos) $)$ \\
\hline $\begin{array}{l}60 \\
61 \\
62\end{array}$ & Mara & $\begin{array}{l}\text { ((risos)) não? você não quer falar? tem } \\
\text { mais alguma pergunta dos seus amigos que } \\
\text { você ach= }\end{array}$ \\
\hline $\begin{array}{l}63 \\
64\end{array}$ & Giovana & $\begin{array}{l}\text { [ah vamo vê:: ah essa daqui ô: : eu } \\
\text { gostei dessa daqui né o Breno né } \uparrow\end{array}$ \\
\hline 65 & Mara & aham \\
\hline 66 & Giovana & ele perguntou né $\uparrow$ do you like kids \\
\hline 67 & Mara & ah: : \\
\hline 68 & Giovana & isso foi bem legal né̂ ((risos)) \\
\hline 69 & Mara & você gostou $d=$ \\
\hline 70 & Giovana & [e do you like books né $\uparrow$ \\
\hline 71 & Mara & do you like books= \\
\hline 72 & Giovana & pergunta \\
\hline
\end{tabular}




\begin{tabular}{|l|l|l|}
\hline 73 & & perguntas muito específicas né $\uparrow$ \\
\hline 74 & Mara & mas por que cê go-gostou dessas perguntas? \\
\hline 75 & Giovana & bom eu acho que: também seria uma boa ideia \\
76 & & perguntar se a pessoa gostasse de livro né $\uparrow$ \\
77 & & porque seria uma experiência totalmente \\
78 & & diferente se a professora não gostasse de \\
79 & & livros né $\uparrow$ e: : vamo vê do you like kids é \\
80 & & importante você gostar das crianças em um \\
81 & & colégio pra: : né $\uparrow$ crianças ((risos)) \\
\hline
\end{tabular}

Neste fragmento, Giovana conversa comigo e ao mesmo tempo revê as Atividades Pedagógicas com Potencial Exploratório que estavam em cima da mesa, realizadas por ela e pelos colegas em aulas anteriores. Acho importante acentuar que Giovana, aluna-participante, se posiciona como praticante exploratória refletindo e analisando suas atividades e as de seus colegas. Enquanto eu, intencionalmente, assumo a posição de professora-pesquisadora-praticante para gravar a interação, observar Giovana compartilhando suas reflexões, realizar a análise do discurso por ela produzido, e buscar maiores entendimentos a respeito da complexidade do ambiente de nossa sala de aula, a qual está inserida no Programa Bilíngue da escola.

Apontei, no capítulo 4 (seção 4.3.), que uma das funções da avaliação é “construir e manter relações entre falante e ouvinte" (NÓBREGA; ABREU 2019, no prelo apud THOMPSON; HUNSTON, 2000, p. 6). Acho que o riso, nesta interação, tem esta função. Observei que Giovana, nas linhas 36, 48, 53, 59, 68, 81, lança mão do recurso paralinguístico do riso, o que parece indicar a descontração, a espontaneidade e a naturalidade da aluna durante a gravação em áudio, detalhe que não observei no comportamento dos outros alunos participantes. Nas linhas 57-62, fiz uma tentativa para que Giovana explicasse o porquê da última pergunta de entrevista que ela faria para o professor(a) - do you believe in unicorns? (segunda Atividade Pedagógica com Potencial Exploratório, seção 5.4.), o que Giovana recusou com risos. Os risos, tanto dela quanto meu, mostram que nós já sabíamos que ela não queria explicar a pergunta. Ao longo deste fragmento, destaco o riso como elemento interacional avaliativo e interpreto os risos como afeto positivo explícito. Os risos ocorreram durante toda a conversa, inclusive, ao final da gravação, na linha 227 (seção 7.4.), quando Giovana realiza uma avaliação positiva de alta gradação no campo do afeto: "eu amei fazer esse trabalho ((risos))". 
Manuseando as atividades disponíveis em cima da mesa, Giovana lê uma das perguntas que faria para entrevistar um professor de inglês "do you work in another school" (linha 21) e justifica que sua pergunta indicaria se o professor "já teria <alguma> experiência" (linha 27). A escolha do léxico "experiência" pode relacionar-se ao conhecimento profissional (NÓVOA, 2009). A seguir, a aluna reporta outra pergunta "do you have experience with children" (linhas 31-32) e justifica que "isso é importante imagina se a pessoa não tem nenhuma experiência com a criança né <isso seria> um: problema" (linhas 34-36). Aqui a escolha de "experience" ou "experiência" parece estar relacionada com a habilidade do professor no trato com as crianças o que pode nos remeter ao aspecto denominado por Nóvoa (ibidem) como tato pedagógico, já discutidos nos capítulos 4 e 5 . Giovana esclarece que a experiência com crianças é importante e que a falta desta seria algo inconcebível para ela, visto como um problema. Como pode um professor que trabalha na escola não ter experiência com crianças? questionamento levantado por ela ao usar o elemento de alta gradação "imagina se a pessoa" (linha 34), referindo-se ao professor como pessoa/ser humano e não apenas um profissional. Nesse sentido, Giovana revela suas crenças de que um bom professor deve ter experiências prévias para que possa ser qualificado a dar aulas para crianças no ambiente pedagógico com o qual a aluna encontra-se familiarizada.

Em seguida, Giovana lê outra pergunta em sua lista "did you live in another country" (linhas 38-39) e justifica sua escolha dizendo que a pessoa/professora "poderia saber outra língua isso seria muito interessante [...] a experiência de um lugar diferente" (linhas 41-45). O uso do intensificador "muito" aumenta a força avaliativa do adjetivo "interessante" parecendo revelar a crença de que o professor deve, ou deveria, ter vivências em outros países durante sua formação acadêmica e profissional. A crença de que "aprender a falar inglês é 'lá fora' e nunca na escola" (ARAGÃO, 2019, p. 253), mencionada no capítulo 4, parece ser compartilhada por Giovana.

O uso do léxico "experiência", repetido por Giovana algumas vezes, pode indicar suas crenças de que o bom professor de inglês deveria ter 
experiências prévias (i) em ambiente profissional, (ii) na relação com as crianças e (iii) uma certa proficiência linguística, a qual Giovana reforça ao dizer que uma professora deveria estudar inglês por "uns dez anos". O período, pela aluna enfatizado, pode aqui ser considerado como um elemento avaliativo de gradação uma vez que corresponde quase à sua idade. Desse modo, é possível inferir que Giovana, através das perguntas que faria para entrevistar um professor, realiza uma avaliação com base no campo semântico de julgamento acerca da capacidade do professor - o quão capaz o professor é em seu conhecimento linguístico, pedagógico e cultural.

Apesar da pouca idade, Giovana e seus colegas participantes apresentam bastante maturidade em suas colocações acerca do professor de inglês. Essa maturidade reflexiva é construída e incentivada na escola assim como oportunizada em nossas aulas no Programa Bilíngue. Como professora-praticante, entendo que a proposta reflexiva e inclusiva da Prática Exploratória me permite trocas e entendimentos que são gerados no ambiente pedagógico. Nesse trabalho coletivo, buscamos entender nossas questões levando em conta não somente as questões de construção de conhecimento, mas também as afetivas e interacionais.

Pelas suas perguntas para entrevistar um professor de inglês, Giovana mostra seu conhecimento acerca do gênero entrevista de trabalho e revela discursivamente suas crenças. Assim como Theo no excerto a seguir, Giovana refere-se ao professor como um profissional da educação.

\section{Excerto 2 - Theo - "tem que pensar um pouco dentro da caixa e um pouco fora da caixa"}

\begin{tabular}{|c|c|c|}
\hline $\begin{array}{l}204 \\
205\end{array}$ & Mara & $\begin{array}{l}\text { e: pra ser um bom professor de inglês o que } \\
\text { cê acha que uma pessoa tem que fazer? }\end{array}$ \\
\hline $\begin{array}{l}206 \\
207\end{array}$ & Theo & $\begin{array}{l}\text { tem que: pensar um pouco dentro da caixa e } \\
\text { um pouco fora da caixa }\end{array}$ \\
\hline 208 & Mara & me explica melhor \\
\hline 209 & Theo & por exemplo você tem que pensar dentro \\
\hline 210 & & tem que pensar \\
\hline 211 & & matéria mas se: : os alunos não estiverem nem \\
\hline 212 & & interessados tem que \\
\hline 213 & & fora da caixa pra uma solução >por exemplo< \\
\hline 214 & & é:: você é teacher de inglês e ai:: cê tá \\
\hline 215 & & mostran:do né: tá fazendo algumas perguntas \\
\hline 216 & & e tal se os alunos não tiverem interessados \\
\hline 217 & & cê faz alguma brincadeira ou alguma coisa \\
\hline 218 & & assim pra deixar eles mais interessados \\
\hline 219 & Mara & ${ }^{\circ}$ humhum ${ }^{\circ}$ \\
\hline
\end{tabular}




\begin{tabular}{|c|c|c|}
\hline $\begin{array}{l}220 \\
221 \\
222 \\
223 \\
224\end{array}$ & heo & $\begin{array}{l}\text { de vez em quando você para né } \uparrow \text { >tipor se eu } \\
\text { fosse um professor eu ia parar um pouco a } \\
\text { aula e brincar de brincadeira que ensinasse } \\
\text { e divertisse pra que eles ficassem mais } \\
\text { atentos à aula que eu taria dan:do }\end{array}$ \\
\hline $\begin{array}{l}225 \\
226 \\
227 \\
228 \\
229\end{array}$ & $a r$ & $\begin{array}{l}\text { então pra você isso seria uma coisa } \\
\text { importante uma caracteristica importante do } \\
\text { professor, tem alguma outra característica } \\
\text { que você acha importante num professor de } \\
\text { inglês? }\end{array}$ \\
\hline $\begin{array}{l}230 \\
231\end{array}$ & Theo & $\begin{array}{l}\text { não acho que só: essas assim pra ser um bom } \\
\text { professor }\end{array}$ \\
\hline 232 & ara & ${ }^{\circ}$ humhum ${ }^{\circ}$ \\
\hline $\begin{array}{l}234 \\
235 \\
236 \\
237\end{array}$ & Theo & $\begin{array}{l}\text { só essa mesmo prestar bastante atenção na } \\
\text { matéria e nos alunos porque tipo se tiver } \\
\text { algum aluno conversando por muito tempo o } \\
\text { professor de vez em quando nem percebe }\end{array}$ \\
\hline 238 & $\operatorname{ar}$ & aham \\
\hline $\begin{array}{l}239 \\
240 \\
241 \\
242 \\
243\end{array}$ & Theo & $\begin{array}{l}\text { tipo ... o aluno tá conversando já há meia } \\
\text { hora com o outro quando ele fala um } \\
\text { pouquinho mais alto você percebe mas aí: cê } \\
\text { não viu antes então cê tem que perceber um } \\
\text { pou: :co mais }\end{array}$ \\
\hline
\end{tabular}

Neste excerto, Theo, ao responder à minha pergunta, relata que um bom professor de inglês "tem que pensar um pouco dentro da caixa e um pouco fora da caixa" (linhas 206-207), o que interpreto como uma avaliação do comportamento do professor no âmbito profissional. Para mim, pensar dentro da caixa é pensar no conteúdo, no currículo da disciplina que o professor está ensinando. Assim, pensar dentro da caixa poderia ser a zona de conforto do professor, aquilo que ele sabe fazer ou preparar para atingir seus objetivos pedagógicos como: elaborar planos de aula e atividades, criar condições para que os alunos aprendam e se desenvolvam, avaliar, entre outras tarefas. Pensar dentro da caixa parece envolver os saberes pedagógico e linguístico, pilares essenciais na formação inicial e em serviço do professor de inglês. Ao passo que pensar fora da caixa envolve ser criativo, requer conhecimento, habilidade e atitude, significa enxergar várias possibilidades e encontrar novas formas de agir, em outras palavras, pensar fora da caixa envolve uma postura reflexiva e inclusiva do professor.

Meu olhar investigativo de pesquisadora-praticante me posiciona como alguém que busca maiores entendimentos ao solicitar "me explica melhor" (linha 208), o que leva Theo a desenvolver seu pensamento. Para Theo, "você 
tem que pensar dentro da caixa você tem que pensar um pouco na matéria" (linhas 210-211). Em seguida, Theo cria um situação hipotética, que contrapõe-se à ideia de pensar dentro da caixa, iniciada pela conjunção se: junto com o recurso paralinguístico de alongamento de vogal "mas se: : os alunos não estiverem nem um pouquinho interessados tem que pensar fora da caixa pra uma solução" (linhas 211-213). Theo esclarece que, apesar de entender quais são as obrigações do professor, o bom professor é aquele que "tem que pensar fora da caixa pra uma solução", caso os alunos não estejam nem um pouquinho interessados, o que revela força avaliativa negativa através do sufixo diminutivo. Para o aluno, pensar fora da caixa implica brincar, fazer "alguma brincadeira ou alguma coisa assim pra deixar eles mais interessados" (linhas 217-218).

Na minha análise, ao apontar que o professor "tem que: pensar um pouco dentro da caixa e um pouco fora da caixa" (linha 206-207), Theo realiza uma avaliação do comportamento do professor no âmbito do julgamento de estima social de capacidade, ou seja, o quão capaz é o professor de pensar dentro e fora da caixa.

Nas linhas 220 a 223, Theo se coloca na posição de professor em uma situação hipotética "se eu fosse um professor eu ia parar um pouco a aula e brincar de brincadeira que ensinasse e divertisse pra que eles ficassem mais atentos", o que parece indicar que, para o aluno, mesmo quando o professor brinca ou faz brincadeiras, sua intenção deve ser a de ensinar e a de manter os alunos atentos. A função do professor na sala de aula, segundo Theo, é "prestar atenção na matéria e nos alunos" (linhas 234-235) assim como no que está acontecendo, "perceber um pouco mais" (linha 243) o que os alunos estão fazendo. Essa postura que concebe o professor como controlador relaciona-se à concepção bancária criticada por Freire ([1974]1979) e é contrária aos princípios e proposições da Prática Exploratória (ALLWRIGHT; HANKS, 2009), discutidas no capítulo 2. Apesar que estar em uma escola que incentiva trocas e reflexões entre professores e alunos na sala de aula, Theo parece trazer em seu discurso crenças acerca do professor como sujeito ativo e do aluno como sujeito passivo. 
Nas linhas 212-213, ao afirmar que o professor "tem que pensar fora da caixa pra uma solução", Theo revela sua crença de que o professor tem o poder de controlar o ambiente e tomar decisões sozinho. Conforme aponta, nas linhas 217-218, "cê faz alguma brincadeira ou alguma coisa assim pra deixar eles mais interessados", o que parece indicar que o professor faz brincadeiras com o propósito de ensinar, de manter os alunos interessados e sob controle. Em contrapartida, o aluno é entendido como ser passivo e "se: os alunos não tiverem nem um pouquinho interessados" (linhas 211-212) é tarefa do professor mantê-los interessados. Ao se posicionar desta forma, Theo parece acreditar que o professor é responsável pela aprendizagem dos alunos contrastando com a proposição de Allwright (ALLWRIGHT; HANKS, 2009, p. 5-7): “Os aprendizes são capazes de se desenvolverem como praticantes da aprendizagem". Assim, Theo revela, pelas escolhas léxico-gramaticais que realiza, suas crenças de que o professor é responsável pela aprendizagem e pela motivação dos alunos no ambiente escolar. Diferentemente de Giovana, mas se assemelhando ao posicionamento de Tito no próximo excerto, Theo revela a não agentividade dos alunos, pelo menos, no momento em que nossa conversa exploratória aconteceu. Percebo uma certa contradição entre as propostas da escola e o posicionamento discursivo de Theo.

Nas linhas 239-243, o aluno cria uma situação de sala de aula: "O aluno tá conversando já há meia hora com o outro quando ele fala um pouquinho mais alto você percebe mas aí cê não viu antes então cê tem que perceber um pouco mais". Acredito que Theo não esteja se referindo às aulas do Programa Bilíngue, pois com sete alunos na sala de aula seria pouco provável não perceber alunos conversando por tanto tempo. Conversar faz parte do cotidiano das aulas assim como faz parte da proposta reflexiva da Prática Exploratória o ver e o ouvir cuidadosos do professor para o que acontece na sala de aula.

Retomando às linhas 239-243, Theo parece revelar que é responsabilidade do professor perceber o que os alunos estão fazendo ou não, como se os mesmos precisassem ser controlados e vigiados no espaço escolar. Observo que as reflexões de Theo e, em seguida, as de Tito parecem se contrapor ao trabalho feito na escola e à minha proposta reflexiva de aula. 


\section{Excerto 3 - Tito - "o trabalho é ensinar a gente"}

\begin{tabular}{|c|c|c|}
\hline $\begin{array}{l}103 \\
104 \\
105 \\
106\end{array}$ & Mara & $\begin{array}{l}\text { uma outra coisa que eu ia te perguntar é que } \\
\text { uma vez você falou que um professor de } \\
\text { inglês tem que ser cinteligente> e } \\
\text { <engraçado> }\end{array}$ \\
\hline 107 & Tito & [não é necessariamente que tem que ser] \\
\hline 108 & Mara & ah \\
\hline 109 & Tito & mas se for ... é uma coisa muito legal \\
\hline 110 & Mara & por quê? \\
\hline $\begin{array}{l}111 \\
112 \\
113 \\
114 \\
115 \\
116 \\
117 \\
118 \\
119\end{array}$ & Tito & $\begin{array}{l}\text { porque os professores têm que fazer o } \\
\text { trabalho o trabalho é ensinar a gente e nos } \\
\text { preparar pra faculdade essas coisas eles } \\
\text { fazem seu trabalho sim ma:s seria muito mais } \\
\text { divertido aprender com eles ao mesmo tempo } \\
\text { que eles brincassem com a gente porque têm } \\
\text { vários professores que falam que ao mesmo } \\
\text { tempo que eles nos ensinam a gente pode } \\
\text { ensinar coisas diferentes pra eles }\end{array}$ \\
\hline
\end{tabular}

Neste trecho, inicio pedindo para Tito comentar sobre sua ideia de que de que um professor de inglês deveria ser inteligente e engraçado. $\mathrm{O}$ aluno mostra que os dois atributos juntos podem ocorrer ou não em relação à figura do professor, não havendo necessidade absoluta desta combinação, a qual ele deixa marcada pelo adjunto modal "necessariamente" (linha 107). Em seguida, o aluno indica uma oposição de ideias com sua escolha "mas se for ... é uma coisa muito legal" (linha 109), o que me leva a interpretar que um professor inteligente e engraçado é reconhecido como algo agradável pelo aluno. O uso do elemento de intensidade acrescido do recurso paralinguístico de ênfase reforçam a ideia de que os dois atributos juntos seriam positivos. Assim, Tito avalia o professor inteligente e engraçado, realizando um julgamento positivo de estima social institucionalizado no afeto. Para mim, o que Tito quer dizer é que ele gosta de professores inteligentes e engraçados.

Na sequência, minha pergunta 'por quê?' (linha 110) dá a chance para o aluno elaborar melhor seu pensamento. Assim, Tito explica que "os professores têm que fazer o trabalho o trabalho é ensinar a gente e nos preparar pra faculdade" (linhas 112-113). Tito sugere a ideia de obrigação, em outras palavras, seria obrigação do professor executar seu trabalho que é o de ensinar os alunos (cf. educação bancária, FREIRE, [1974]1979). De acordo com Tito, a tarefa primordial do professor é ensinar e preparar para a faculdade, a qual seria a meta, o ponto a que se almeja chegar em 
termos educacionais. Esta visão parece indicar crenças social e culturalmente construídas de que a escola é a passagem para universidade ou que a escola serve como porta de entrada para universidade. No meu entendimento, apesar de o aluno revelar suas crenças do ensino como ascensão social, para uma criança de 10 anos de idade, a faculdade é ainda algo distante e vago. Nesse contexto, de acordo com suas escolhas, o aluno realiza um julgamento positivo de estima social de capacidade do professor. O professor é julgado, por Tito, pela sua competência/capacidade de preparar os alunos para o futuro em uma universidade.

Tito parece restringir a função do professor a ensinar, o que fica evidente em sua escolha "o trabalho é ensinar a gente" (linha 112). Ensinar é a obrigação do professor, para tal, "eles fazem seu trabalho sim ma:s seria muito mais divertido aprender com eles ao mesmo tempo que eles brincassem com a gente" (linhas 114-116). Tito não só afirma que os professores "fazem seu trabalho" mas também reafirma sua posição com a escolha do advérbio "sim", realizando uma avaliação de julgamento de estima social de capacidade. Tito deixa claro que está ciente de que os professores realizam seu trabalho que é ensinar os alunos e, em seguida, faz uma oposição marcada pela conjunção "ma:s", lançando mão dos recursos linguísticos de alongamento de vogal e ênfase para apresentar duas ideias: professor/obrigação/trabalho contrastando com aluno/diversão/aprendizagem.

A partir da minha interpretação, as escolhas linguísticas do aluno parecem indicar a crença de que aprender tem que ser divertido. Além do elemento intensificador, Tito lança mão do recurso paralinguístico de ênfase para expressar seu ponto de vista de que seria "muito mais divertido" aprender com professores que brincam. A ideia de simultaneidade é expressa na escolha de "ao mesmo tempo", a qual parece indicar que os professores deveriam brincar sem deixar de lado a função de ensinar. Tito, de certa forma, aponta que brincar, para o professor, pode ser associado a trabalho, obrigação, tarefa e ensino, ao passo que brincar, para o aluno, está conectado ao lúdico, ao prazer e à recreação. Entendo que Tito reproduz, nesta visão, crenças socialmente construídas de que a tarefa do professor é ensinar enquanto a dos alunos é aprender se divertindo. Tais crenças nos remetem à posição do professor como agente ativo e do aluno como ser 
passivo no processo de ensino e de aprendizagem (FREIRE, [1974]1979), conforme discutida no capítulo 2 .

Nas linhas 116-119, Tito explica que "vários professores que falam que ao mesmo tempo que eles nos ensinam a gente pode ensinar coisas diferentes pra eles". A escolha do atributo "vários", na linha 116, tanto qualifica os professores trazendo a ideia de diversidade quanto quantifica indicando que são muitos e não a apenas alguns. O aluno parece mostrar que convive com muitos professores que compartilham a ideia de que somos todos aprendizes. Com a escolha de "vários professores que falam" (linha 117), Tito traz a voz do professor para apontar que professores ensinam e aprendem "ao mesmo tempo" (linhas 117-118). Nessa avaliação, o aluno parece expressar ideias contidas na proposição, "os aprendizes são capazes de se desenvolverem como praticantes da aprendizagem" (ALLWRIGHT; HANKS, 2009, p. 5-7), mencionada no capítulo 2. Nesse sentido, professores e alunos ensinam e aprendem nas interações do cotidiano escolar, trocam informações e compartilham seus conhecimentos e experiências.

No próximo excerto, Breno reforça a crença expressa por Tito de que a professora tem que brincar e ensinar ao mesmo tempo.

\section{Excerto 4 - Breno - "[saber] bem inglês e saber de algumas culturas inglesas"}

\begin{tabular}{|c|c|c|}
\hline $\begin{array}{l}77 \\
78\end{array}$ & Mara & $\begin{array}{l}\text { então é: que você fez aqui nesta atividade? } \\
\text { cê pode me explicar? cê lembra= }\end{array}$ \\
\hline 79 & Breno & [eu me lembro] \\
\hline 80 & Mara & >então tá< \\
\hline 81 & Breno & eu fiz de uma: : boa professora de inglês \\
\hline $\begin{array}{l}82 \\
83\end{array}$ & Mara & $\begin{array}{l}\text { então mas o que cê escreveu sobre ela } \ldots \\
\text { essa professora? }\end{array}$ \\
\hline $\begin{array}{l}84 \\
85 \\
86\end{array}$ & Breno & $\begin{array}{l}\text { escrevi do jeito: ela: ser legal, brincar } \\
\text { assim fazer brincadeira enquanto dá aula, } \\
\text { falar inglês muito bem }\end{array}$ \\
\hline $\begin{array}{l}87 \\
88 \\
89\end{array}$ & Mara & $\begin{array}{l}\text { por que por que você escreveu que tem que } \\
\text { falar inglês muito bem? o que é falar inglês } \\
\text { bem pra você? }\end{array}$ \\
\hline 90 & Breno & ter um conhecimento bem do: de inglês \\
\hline $\begin{array}{l}91 \\
92\end{array}$ & Mara & $\begin{array}{l}\text { mas assim qual conhecimento? } \\
\text { melhor }\end{array}$ \\
\hline 93 & Breno & conhecimento das palavras, do jei:to \\
\hline 94 & Mara & das palavras, o que seria esse jeito? \\
\hline 95 & Breno & ah o que eles fazem lá, o costume deles \\
\hline 96 & Mara & cultura \\
\hline
\end{tabular}




\begin{tabular}{|c|l|llll|}
\hline 97 & Breno & \multicolumn{4}{|c|}{ [é: : ] } \\
\hline 98 & Mara & $\begin{array}{l}\text { então cê acha que um professor tem que } \\
\text { saber= }\end{array}$ & & & \\
\hline 100 & Breno & [bem inglês e saber de algumas culturas \\
101 & & inglesas] & & & \\
\hline 102 & Mara & tá bom de outros países que falam inglês, é \\
103 & & isso? & & & \\
\hline 104 & Breno & humhum & & & \\
\hline
\end{tabular}

Iniciamos com minha pergunta sobre a Atividade Pedagógica com Potencial Exploratório A good English teacher, apresentada no capítulo 5. Observo que Breno se posiciona discursivamente com voz autoral e realiza várias avaliações ao se referir à professora de inglês. Para ele, a professora deve (i) "ser legal" (linha 84) - entendido como um atributo positivo, o qual pode significar uma pessoa agradável, interessante, divertida e amável; (ii) "brincar" (linha 84) avaliação positiva relacionada à interação professora-aluno(s) no contexto educacional; (iii) "fazer brincadeira enquanto dá aula" (linha 85) avaliação da capacidade da professora de fazer brincadeiras e dar aulas; (iv) "falar inglês muito bem" (linha 84-85) - avaliação da capacidade linguística da professora.

Segundo Breno, "falar inglês muito bem" é um traço de uma boa professora de inglês e envolve conhecimento linguístico ou "um conhecimento bem do: de inglês" (linha 90); amplo vocabulário ou "conhecimento das palavras" (linha 93); e conhecimento cultural ou "jei:to" (linha 93), "O que eles fazem lá, o costume deles" (linha 95). As escolhas léxico-gramaticais de Breno demonstram que ele realiza uma avaliação no campo semântico do julgamento de estima social acerca da capacidade/competência da professora, revelando que, a professora tem que possuir uma bagagem linguística e cultural na língua inglesa para ser considerada uma boa professora.

Assim como Giovana, Breno menciona a importância das vivências culturais do professor, o que parece revelar crenças socialmente construídas de que o bom professor de inglês é aquele que estudou ou morou em outros países. A questão que chama minha atenção é que, apesar da pouca idade, os alunos já compartilham tais crenças, as quais atribuo ao fato de seus pais não somente terem tido vivências sociais, culturais e educacionais em outros países, mas também ao fato de proporcionarem momentos de aprendizagem em viagens de família. 
Diferentemente dos colegas, Davi focou em outros aspectos que envolvem a relação com o professor, como serão discutidos a seguir.

\section{Excerto 5 - Daniel - "ser bem feliz"}

\begin{tabular}{|c|c|c|}
\hline $\begin{array}{l}62 \\
63 \\
64 \\
65 \\
66 \\
67 \\
68 \\
69\end{array}$ & Mara & $\begin{array}{l}\text { professor de inglês, lembra o que eu tinha } \\
\text { perguntado pra vocês? eu perguntei assim o } \\
\text { que é ser um bom professor de inglês, lembra } \\
\text { que a gente conversou sobre isso? na sua } \\
\text { opinião hoje agora o que é ser um bom } \\
\text { professor de inglês? o que uma pessoa tem } \\
\text { que ter ou fazer pra ser um bom professor de } \\
\text { inglês? }\end{array}$ \\
\hline 70 & Daniel & é:: ser bem feliz \\
\hline 71 & Mara & ${ }^{\circ}$ humhum ${ }^{\circ}$ \\
\hline $\begin{array}{l}72 \\
73 \\
74\end{array}$ & Daniel & $\begin{array}{l}\text { é: } \text { não ser uma pessoa emburrada assim } \\
\text { conversar com os alunos bem é:: que gostar } \\
\text { das crianças né } \uparrow\end{array}$ \\
\hline 75 & Mara & cê acha importante gostar das crianças? \\
\hline 76 & Daniel & sim \\
\hline $\begin{array}{l}77 \\
78 \\
\end{array}$ & Mara & $\begin{array}{l}\text { por que um professor tem que gostar das } \\
\text { crianças? }\end{array}$ \\
\hline $\begin{array}{l}79 \\
80\end{array}$ & Daniel & $\begin{array}{l}\text { pra saber cuidar direito }{ }^{\circ} \text { assimº não ter } \\
\text { muita braveza }\end{array}$ \\
\hline 81 & Mara & braveza? o que é braveza? me explica isso \\
\hline 82 & Daniel & cabei de inventar ((risos)) \\
\hline 83 & Mara & não $\uparrow$ mas o que é braveza? ((risos)) explica $\uparrow$ \\
\hline 84 & Daniel & uma pessoa muito brava \\
\hline 85 & Mara & é: então o professor não pode ser bravo? \\
\hline 86 & Daniel & é : \\
\hline 87 & Mara & não deve? \\
\hline 88 & Daniel & é legal não ser muito bravo ${ }^{\circ}$ essas coisas ${ }^{\circ}$ \\
\hline $\begin{array}{l}89 \\
90 \\
91 \\
92\end{array}$ & Mara & $\begin{array}{l}\text { então se cê tivesse que: entrevistar um } \\
\text { professor, se você tivesse que fazer } \\
\text { perguntas pra ele o que você perguntaria pro } \\
\text { professor? }\end{array}$ \\
\hline $\begin{array}{l}93 \\
94 \\
95\end{array}$ & Daniel & $\begin{array}{l}\text { é: }: . . \text { o que ele gosta de fazer, se ele } \\
\text { gosta de criança, se ele gosta da profissão } \\
\text { dele }\end{array}$ \\
\hline 96 & Mara & é importante gostar da profissão? \\
\hline 97 & Daniel & ((respondeu acenando com a cabeça)) \\
\hline 98 & Mara & por quê? \\
\hline $\begin{array}{r}99 \\
100\end{array}$ & Daniel & $\begin{array}{l}\text { pra é: não ... porque eu disse não ficar ... } \\
\text { gostar de ir acordar bem pra ir pro trabalho }\end{array}$ \\
\hline
\end{tabular}

Neste trecho, peço para Daniel falar sobre a Atividade Exploratória com Potencial Pedagógico A good English teacher. Ao se referir a professora, o aluno realiza duas escolhas que entendo como ideias opostas: num polo "ser bem feliz" (linha 70) e no outro "ser uma pessoa emburrada" (linha 72), no 
sentido de carrancuda ou mal-humorada. Ao dizer que uma professora não deveria "ser uma pessoa emburrada" (linha 72), Daniel faz uma avaliação do comportamento da professora no âmbito do julgamento, indicando que o malhumor de uma professora pode prejudicar a boa convivência na sala de aula.

Em seguida, Daniel acrescenta que o professor deveria "conversar com os alunos" (linha 72), "gostar das crianças" (linha 73-74), "saber cuidar direito" (linha 79) e "não ter muita braveza" (linha 79-80). Após minha insistência nas linhas 81 e 83, Daniel explica que braveza significa "uma pessoa muito brava" (linha 84). Observo que Daniel destaca comportamentos e atitudes que considera apropriados para um professor ao fazer uso do processo verbal "conversar"; do processo mental emotivo "gostar" e do cognitivo "saber"; e do processo relacional possessivo "ter". Neste momento, Daniel realiza um julgamento estima social de capacidade, ou seja, sugerindo que o professor seja capaz de conversar, de gostar, de saber cuidar com doçura e delicadeza, sem "muita braveza". Vale destacar o afeto implícito nos processos escolhidos pelo aluno no julgamento que realiza a respeito do comportamento do professor. Na minha visão, Daniel quis dizer que gosta de professoras que conversam com os alunos, que sabem cuidar das crianças, que expressam afeto e que não gosta de conviver com professoras bravas, zangadas e emburradas.

Quando questionado, nas linhas 89-92, sobre o que perguntaria para o professor na entrevista de trabalho em relação à segunda Atividade Pedagógica com Potencial Exploratório apresentada no capítulo 5, Daniel elencou três itens: "o que ele gosta de fazer, se ele gosta de criança, se ele gosta da profissão dele" (linhas 93-95). A repetição do processo mental emotivo 'gostar' parece evidenciar a importância que Daniel atribui à dimensão afetiva do professor, na qual convergem a vida pessoal e a institucional (GIEVE; MILLER, 2006, p. 40). Na minha análise, Daniel realiza suas avaliações no campo do afeto, o que mostra marcas de afeto no campo do julgamento. Ao mesmo tempo que está julgando o comportamento do professor que, para ele, tem que gostar do que faz, das crianças e da profissão, Daniel realiza avaliações no campo semântico do afeto, o que denota o quanto ele parece valorizar a questão 
interacional, o que pode ser justificado devido ao uso de processos e atributos com carga de avaliações positivas, expressando afeto.

A partir de suas experiências individuais, o aluno, na linha 100, reforça sua avaliação de que "gostar de ir" [para o trabalho] e "acordar bem pra ir pro trabalho" devem fazer parte do comportamento de um professor. Nesta situação e contexto, "acordar bem" carrega um sentido de despertar com disposição, entusiasmo, sensação de felicidade, que remete à sensação de bemestar físico e emocional. Assim, ao fazer esta escolha linguística, Daniel expressa um julgamento acerca do comportamento do professor que ao "acordar bem pra ir pro trabalho" (linha 100) seria capaz de executar suas tarefas e interagir com os alunos de bom humor e não emburrado (linha 72), o que me remete à quinta (pre)disposição sugerida por Nóvoa (2009) - o compromisso social, discutida nos capítulos 4 e 5. Contudo, no meu entendimento, esta capacidade do professor encontra-se impregnada de afeto marcado nas escolhas realizadas pelo aluno, tanto no verbo 'gostar' - processo mental de afeição, quanto na gradação positiva 'bem' em "acordar bem" (linha 100).

O compromisso do professor com o aluno envolve dimensões sociais, éticas, profissionais e afetivas. Além de exigências de eficácia profissional, o trabalho do professor exige certo grau de complexidade no que tange às relações e às interações, que são perpassadas por afetos e emoções. Nesse sentido, "acordar bem pra ir pro trabalho" (linha 100) é o mesmo que dizer que um bom professor tem que "ser bem feliz" (linha 70), o que mostra o valor que Daniel atribui ao comportamento do professor, revelado por suas escolhas léxico-gramaticais.

Daniel indica, pelas suas escolhas, uma compreensão da importância do bem-estar emocional do professor no ambiente escolar. Sua percepção encontra-se relacionada à qualidade de vida na sala de aula, uma prioridade de acordo com os Princípios da Prática Exploratória, apresentados e discutidos no capítulo 2. O bem-estar do professor pode ser disseminado entre os alunos no contexto de interação da sala de aula, sendo essa uma experiência individual. Diferentemente de Giovana, Theo, Breno e Tito nos excertos anteriores e Gael no próximo excerto, que parecem priorizar o conhecimento linguístico do professor, Davi, em 
suas avaliações, traz à tona a importância do aspecto afetivo nas relações construídas em sala de aula.

\section{Excerto 6 - Gael - "aprender inglês é uma coisa, saber falar inglês bem é uma coisa muito legal"}

\begin{tabular}{|c|c|c|}
\hline $\begin{array}{l}127 \\
128 \\
129\end{array}$ & Mara & $\begin{array}{l}\text { seria uma professora de inglês e você } \\
\text { perguntou assim se ela fala inglês bem o que } \\
\text { é falar inglês bem? o que vo= }\end{array}$ \\
\hline $\begin{array}{l}130 \\
131 \\
132 \\
133 \\
134 \\
135 \\
136 \\
137 \\
138 \\
139 \\
140 \\
141\end{array}$ & Gael & 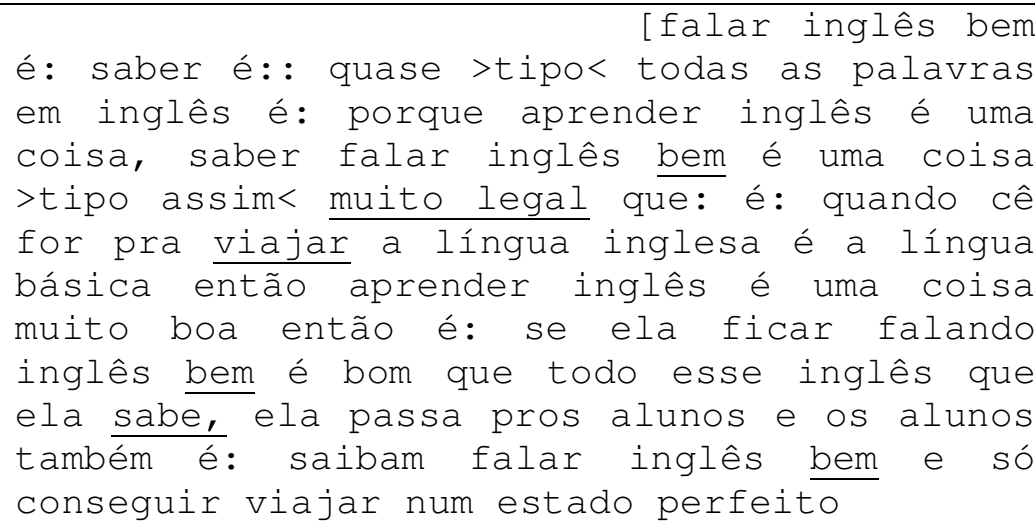 \\
\hline $\begin{array}{l}142 \\
143 \\
144 \\
145\end{array}$ & Mara & $\begin{array}{l}\text { <nossar muito bom mais alguma pergunta que } \\
\text { você acha importante fazer pra uma } \\
\text { professora que vai chegar na escola? ... cê } \\
\text { lembra de mais alguma? }\end{array}$ \\
\hline $\begin{array}{l}146 \\
147 \\
148 \\
149 \\
150 \\
151 \\
152 \\
153 \\
154 \\
155 \\
156 \\
157\end{array}$ & Gael & $\begin{array}{l}\text { mmmm ... é: se você se ela é uma professora } \\
\text { séria ou engraçada porque tem muitos } \\
\text { diferentes tipos de: professora umas que } \\
\text { levam a aula a sério e outras que brincam é: } \\
\text { as professoras que brincam muito às vezes } \\
\text { até que não são tão boas porque os alunos ah } \\
\text { tipo: na hora de fazer >sei lá< falar muito } \\
\text { ou fazer alguma gracinha >ah sei lá< essa } \\
\text { professora é muito engraçada ela não vai } \\
\text { brigar comigo e aí eles continuam fazendo } \\
\text { gracinha e não conseguem passar pro próximo } \\
\text { ano o ano inteiro eles não mudaram nada }\end{array}$ \\
\hline 158 & Mara & ${ }^{\circ}$ humhum ${ }^{\circ}$ \\
\hline $\begin{array}{l}159 \\
160 \\
161 \\
162 \\
163 \\
164\end{array}$ & Gael & $\begin{array}{l}\text { é: mas também uma professora muito sérias } \\
\text { séria é: às vezes é chato >tipo< é: f fica } \\
\text { achando que tem que ser tudo certinho e } \\
\text { qualquer coisa que você fale vai brigar } \\
\text { muito com você é muito bom ter uma } \\
\text { professora no meio-termo }\end{array}$ \\
\hline
\end{tabular}

O trecho destacado refere-se à Atividade Pedagógica com Potencial Exploratório, na qual Gael elaborou perguntas para entrevistar um professor de inglês. Gael responde à minha indagação esclarecendo que uma boa professora de inglês tem que "falar inglês bem" (linha 130) e "saber é: : quase >tipo< todas as palavras em inglês" (linhas 131-132). Apesar da 
graduação contida no léxico 'quase', o aluno enfatiza que a professora deve saber/conhecer aproximadamente todas as palavras da língua, parecendo indicar que a professora detém o conhecimento da língua e tem como função transmiti-lo aos alunos. Essa postura é contrária a agentividade dos aprendizes contida nas cinco Proposições de Allwright e Hanks (2009, p. 5-7), comentadas no capítulo 2 sobre a Prática Exploratória.

As escolhas empregadas por Gael do processo verbal "falar" (linha 130) e do mental cognitivo "saber" (linha 131) me levam a interpretar que Gael prioriza o conhecimento linguístico em detrimento de questões interacionais como as apontadas por Daniel no excerto anterior. Gael parece entender a professora como detentora do saber que tanto deve falar bem o idioma quanto apresentar amplo vocabulário. Com suas escolhas léxico-gramaticais, Gael realiza uma avaliação no campo semântico do julgamento acerca da capacidade da professora de falar bem e de possuir bom vocabulário, o que parece indicar que esta seria uma condição necessária, uma exigência ou uma obrigação da professora, na visão do aluno. Acho que Gael quis dizer que para ser professora de inglês é fundamental ter conhecimento da língua e ser capaz de comunicar-se com fluência, o que parece alinhado ao pensamento de Nóvoa (2009) de que o professor tem que conhecer bem o que ensina, conforme apresentado e discutido nos capítulos 4 e 5 .

Em seguida, o aluno explica que "aprender inglês é uma coisa, saber falar inglês bem é uma coisa >tipo assim< muito legal" (linhas 132-134). Gael apresenta duas ideias distintas. A primeira parece estar relacionada com estudar, instruir-se, ter contato com a língua. Já a segunda referese à fluência verbal, à habilidade de falar e de compreender o idioma nas interações entre pessoas, a qual Gael avalia positivamente com a escolha de "muito legal", lançando mão do recurso paralinguístico de ênfase.

Nas linhas 137-141, Gael realiza uma avaliação no campo semântico do julgamento da capacidade do professor, relacionando a habilidade de falar inglês bem diretamente ao aprendizado dos alunos. Para isto, Gael cria uma situação hipotética "se ela [a professora] ficar falando inglês bem é bom" (linhas 137-138), avaliando de forma positiva o fato de a professora fazer uso do idioma com fluência na sala de aula. Na sequência, o aluno explica que "todo esse inglês que ela sabe ela passa pros alunos" (linhas 138- 
139). Neste momento, Gael constrói uma identidade passiva para os alunos e ativa para a professora, enfatizando que ela passa ou transfere seus saberes e conhecimentos para os alunos. Essa postura passiva dos alunos no que diz respeito à responsabilidade individual como construtores do conhecimento foi apontada por Theo e Tito em excertos anteriores.

Por duas vezes, Gael faz uso do processo material de movimento 'viajar': nas linhas 134-135, "quando for pra viajar a língua inglesa é a língua básica" e nas linhas 140-141, "conseguir viajar num estado perfeito". Desse modo, Gael parece entender inglês como língua franca, a qual é usada em contexto global como idioma essencial ou indispensável, em suas palavras, "língua básica" (linha 135-136) para a comunicação entre as pessoas que transitam pelos continentes. $\mathrm{O}$ fato de associar o aprendizado da língua inglesa a viagens parece revelar suas próprias experiências familiares e vivências socioculturais. De acordo com este fragmento, é possível inferir que "viajar num estado perfeito" (linha 141) refere-se à habilidade do aluno de comunicar-se, fazendo uso da língua inglesa em interações durante as viagens. Lembrando que, segundo Gael, tal habilidade é atribuída à capacidade do professor de transmitir/transferir seu inglês para os alunos em um ambiente onde o professor ensina enquanto o aluno aprende, tal qual no modelo de educação bancária criticado por Freire ([1974]1979).

$\mathrm{Na}$ sequência, ainda se referindo à Atividade Pedagógica com Potencial Exploratório, Gael relata que existem dois tipos de professoras: "umas que levam a aula a sério e outras que brincam" (linhas 148-149). Dessa forma, o aluno categoriza as professoras em dois grupos, explicando que as que brincam "não são tão boas" (linha 151) e, por outro lado, "uma professora muito [...] séria é: às vezes é chato" (linhas 159160). Apesar da modalização contida em "às vezes" (linhas 150 e 160), o aluno realiza um julgamento explícito de estima social de normalidade do comportamento dos dois grupos de professoras. Ou seja, o quão especial ou não é a professora que brinca? O quão especial ou não é a professora séria? Para Gael, as professoras que brincam muito podem causam prejuízos ao desenvolvimento e à aprendizagem dos alunos, pois os mesmos "não conseguem passar pro próximo ano, o ano inteiro eles não mudaram nada" (linhas 156- 
157). É possível notar que, com suas escolhas, Gael realiza um julgamento de estima social, atribuindo à professora a responsabilidade pelos sucessos ou insucessos escolares, assim como pelas conquistas ou fracassos dos alunos.

Quanto às professoras sérias, segundo Gael, essas ficam "achando que tem que ser tudo certinho" (linhas 160-161). Este comportamento em uma professora é considerado, pelo aluno, como "Chato" (linha 160) no sentido de desagradável e inconveniente. Desse modo, Gael realiza uma avaliação negativa de julgamento de estima social de comportamento da professora centrada no afeto, que pode ser entendida como: ele acha chato ter uma professora exigente e preocupada com os detalhes. O léxico "certinho" (linha 161) encontra-se impregnado de sentido avaliativo e traz uma gradação de força que acentua e enfatiza negativamente a postura da professora exigente $\mathrm{e}$ perfeccionista. Na sequência, nas linhas 162-163, Gael realiza uma avaliação negativa explícita da professora séria reportando que "qualquer coisa que você fale vai brigar muito com você". A partir da minha interpretação, o tipo de professora descrita seria autoritária e inflexível em suas interações com os alunos.

Após apresentar os dois polos opostos, Gael conclui que "é muito bom ter uma professora no meio-termo" (linhas 163-164). Da forma como interpreto, Gael quis dizer que a professora ideal, para ele, seria aquela capaz de se posicionar de forma equilibrada, com atitudes moderadas e sensatas, capaz de transmitir segurança, de ser afetiva mas firme e coerente com as regras necessárias para o bom andamento das aulas. Ao dizer que gosta de professoras "meiotermo" (linha 164), Gael realiza uma avaliação instanciada no afeto, ou seja, ele gosta de professoras meio-termo, um comportamento entre levar a aula à sério e brincar.

Bruna, no próximo excerto, valoriza a figura do professor, que segundo ela podem ser bravos ou legais.

\section{Excerto 7 - Bruna - "cada professor é do seu jeito"}

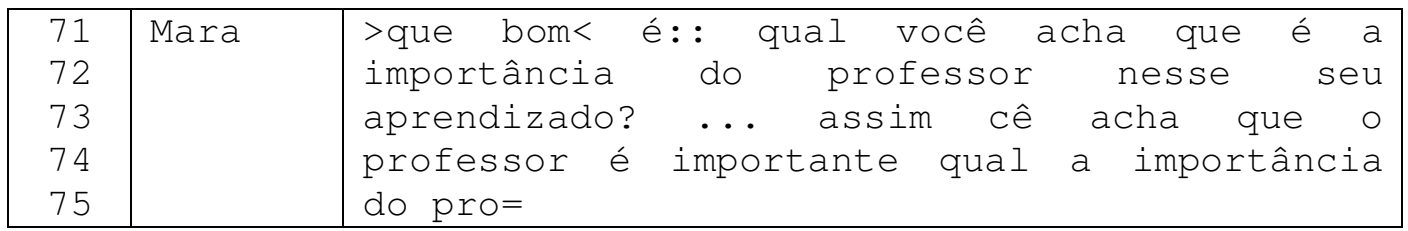




\begin{tabular}{|c|c|c|}
\hline $\begin{array}{l}76 \\
77 \\
78 \\
79 \\
80 \\
81 \\
82 \\
83 \\
84 \\
85 \\
86 \\
87\end{array}$ & Bruna & 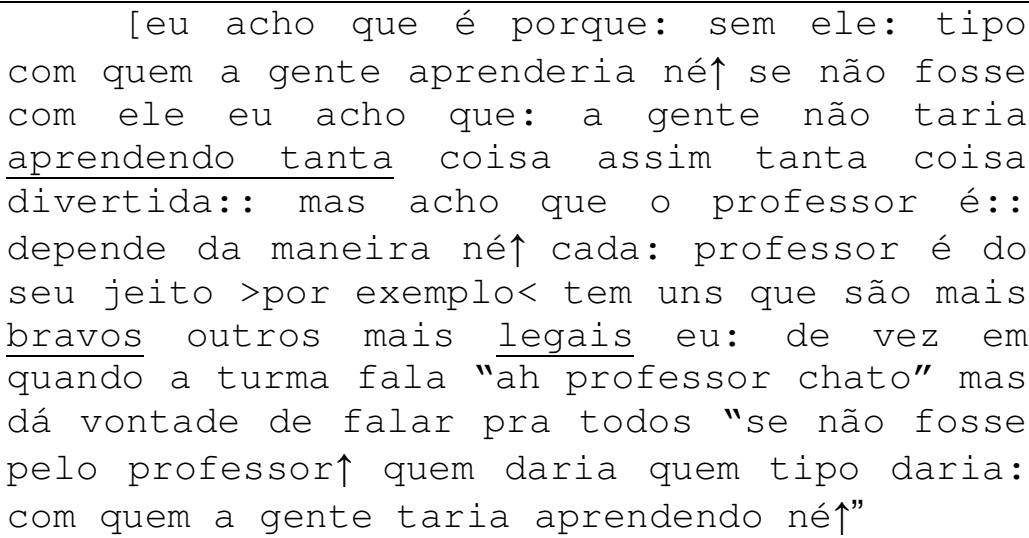 \\
\hline 88 & Mara & {$\left[{ }^{\circ}\right.$ humhum $\left.^{\circ}\right]$} \\
\hline 89 & Bruna & como saberia tudo que a gente sabe até hoje؟ \\
\hline $\begin{array}{l}90 \\
91\end{array}$ & Mara & $\begin{array}{l}\text { mas você acha que você aprende com seus } \\
\text { amigos também] }\end{array}$ \\
\hline 92 & Bruna & [sim] \\
\hline 93 & Mara & [com os colegas? \\
\hline $\begin{array}{l}94 \\
95 \\
96 \\
97 \\
98 \\
99\end{array}$ & Bruna & $\begin{array}{l}\text { sim né porque de vez em quando eu posso ter } \\
\text { faltado uma aula: ou não ter entendido } \\
\text { certas matérias porque eu odeio história é } \\
\text { legal aprender sobre o Brasil mas eu não } \\
\text { gosto muito então é uma coisa que meus } \\
\text { amigos também me ensinam bastante né } \uparrow\end{array}$ \\
\hline 100 & Mara & {$\left[{ }^{\circ}\right.$ humhum $\left.{ }^{\circ}\right]$} \\
\hline 101 & Bruna & como o professor pode mais ou menos ensina \\
\hline $\begin{array}{l}102 \\
103\end{array}$ & Mara & $\begin{array}{l}\text { okay o que você acha que o professor pode } \\
\text { fazer pra ajudar você a aprender mais= }\end{array}$ \\
\hline 104 & Bruna & [é: : \\
\hline 105 & Mara & [professor de inglês \\
\hline $\begin{array}{l}106 \\
107 \\
108 \\
109 \\
110 \\
111 \\
112\end{array}$ & Bruna & $\begin{array}{l}\text { o inglês eu acho que ele sempre: é: deve } \\
\text { pesquisar né certas coisas novas pra } \\
\text { aprender e: se: ele: >por exemplo< ele } \\
\text { acaba: é: se ele acaba é se ele não tiver } \\
\text { mais o que dá pra pessoa dá uma revisada: } \\
\text { quem sabe dá uma revisada se você dá uma } \\
\text { ideia de dá alguma coisa né <assim> }\end{array}$ \\
\hline
\end{tabular}

Neste excerto, Bruna se posiciona com voz autoral "eu acho" (linha 76), fazendo uso do processo mental cognitivo, uma escolha que indica sua percepção acerca do professor de inglês. Nas linhas 76-77, a aluna faz uma pergunta retórica "sem ele: tipo com quem a gente aprenderia né $\uparrow "$ com intenção de afirmar que 'sem o professor, o aluno não aprenderia'. Ao mesmo tempo que a aluna enaltece o professor realizando uma avaliação positiva, ela o reduz a uma figura que possui a função de ensinar apenas, apresentando um pensamento contrário às Proposições (ALLWRIGHT; HANKS, 2009, p. 5-7) e ao conceito de aprendiz (cf. learners) que inclui professores e alunos. Ao valorizar a figura do professor como aquele que ensina, Bruna parece colocá-lo no centro do 
processo educativo, o que retira do aluno a agentividade e a autonomia em relação ao seu processo de construção de conhecimentos e de aprendizagens.

Nas linhas 81-82, Bruna realiza uma avaliação positiva de aceitação do professor como individualidade singular ao afirmar que "cada: professor é do seu jeito". Em seguida, a aluna exemplifica que "tem uns que são mais bravos outros mais legais" (linhas 82-83), categorizando os professores em dois grupos antagônicos. Na minha interpretação de suas escolhas lexicais, os professores bravos seriam os mais autoritários e inflexíveis enquanto os legais seriam os mais tolerantes e flexíveis. Com suas escolhas, Bruna realiza uma avaliação do campo semântico do julgamento, uma vez que referem-se ao comportamento dos professores, ou seja, a aluna julga o comportamento dos professores. Ao agrupar os professores em duas categorias, a aluna avalia como comportamento negativo os "bravos" e comportamento positivo os "legais" (linha 83), fato que pode estar relacionado às suas vivências e experiências como aluna, assim como as crenças que constrói acerca do professor.

Apesar de Bruna não haver se posicionado como agente ativa de sua própria aprendizagem, se posiciona como agente ativa nas avaliações que realiza acerca do professor. Aos 10 anos de idade, Bruna revela maturidade até mesmo ao defender o comportamento e atitudes do professor perante seus colegas de turma. Nas linhas 83-87, Bruna usa a fala reportada como recurso para mostrar que não se inclui no grupo de seus colegas de turma que dizem - "ah professor chato", reforçando assim seu posicionamento.

Como resposta aos colegas, Bruna faz uso de outra fala reportada com as perguntas retóricas: "se não fosse pelo professor [...] com quem a gente taria aprendendo" (linhas 85-87) e "como saberia tudo que a gente sabe até hoje" (linha 89). As duas perguntas podem indicar suas crenças de que os alunos precisam ou dependem do professor tanto para aprender quanto para saber, no sentido de conhecer. Com a escolha destes dois processos mentais cognitivos - aprender e saber - Bruna aponta para a importância da capacidade humana de processar informações e de construir saberes e conhecimentos, enfatizando que aquilo que o aluno aprende depende das escolhas e decisões, competências e habilidades do professor. Em outras palavras, a aluna parece esclarecer que a responsabilidade pela função cognitiva da aprendizagem, 
na escola, recai sobre o professor, colocando o aluno como ser passivo e receptor (cf. educação bancária, FREIRE, [1974]1979, p. 67-68).

No questionamento trazido por Bruna em "como saberia tudo que a gente sabe até hoje" (linha 89) o que mais chama a minha atenção é a escolha do léxico "tudo", o qual representa a totalidade e carrega a ideia de completude. Nesse sentido, a aluna parece deixar de lado os aprendizados que ocorrem fora da escola e os que acontecem dentro da escola e que não estão diretamente ligados ao professor. Tal ideia é desfeita quando reponde "sim", nas linhas 92 e 94, a minha pergunta a respeito de aprender com amigos e colegas e quando acrescenta "meus amigos também me ensinam bastante" (linhas 98-99).

Na linha 96, Bruna realiza uma avaliação explicita negativa no campo do afeto ao verbalizar "eu odeio história", em seguida, nas linhas 97-98, ameniza a carga negativa com a escolha de "eu não gosto muito". Os dois processos mentais de afeição por ela escolhidos encontram-se no campo emotivo com gradações diferentes. Ao se posicionar com voz autoral, Bruna enfatiza a carga emotiva com que se expressa.

Referindo-se ao professor de inglês nas linhas 106 a 112, Bruna acha "que ele sempre é: deve pesquisar né certas coisas novas pra aprender". Bruna se posiciona com clareza sobre a importância do professor que está em busca constante de entendimentos acerca de sua prática e de novos conhecimentos. Mais uma vez, a aluna parece compreender o professor como agente, como sujeito do processo de ensino e aprendizagem.

\subsection{1.}

\section{Meus entendimentos}

As vivências diárias no Programa Bilíngue da escola possibilitaram aos sete alunos participantes expressarem opiniões e convicções acerca da figura do professor de inglês. Ao apresentar seus entendimentos sobre quem é ou deveria ser um bom professor de inglês, os alunos realizam julgamentos de comportamento, de capacidade e de normalidade, revelando suas crenças em um contexto sócio-histórico-cultural situado. Vale ressaltar que suas crenças são construídas nas experiências que têm dentro e fora do ambiente escolar. 
Partindo da concepção de que crenças são dinâmicas e mutáveis (BARCELOS, 2004; 2006), é possível apontar que, no momento em que este estudo foi realizado, considerando o contexto, a idade, a escolarização, os aspectos sociais e culturais experimentados individualmente pelos alunos, o professor de inglês tem que ou deve

- ter experiências como professora e vivências em outros países;

- pensar dentro e fora da caixa;

- brincar e ensinar;

- falar inglês bem;

- gostar da profissão;

- gostar dos alunos;

- conversar com os alunos;

- pesquisar coisas novas.

As escolhas léxico-gramaticais realizadas pelos alunos participantes fazem parte do contexto de situação e de cultura, no qual o grupo encontra-se inserido. A partir da avaliação baseada nos pressupostos do Sistema de Avaliatividade (MARTIN; WHITE, 2005), foi possível encontrar subsídios para a análise dos excertos apresentados, visto que, por meio de escolhas léxico-gramaticais, os alunos participantes expõem seus pontos de vista, revelando aspectos relacionados ao afeto e ao julgamento em relação ao professor de inglês.

Nos fragmentos destacados, percebi que, ao oportunizar a reflexão sobre as duas Atividades Pedagógicas com Potencial Exploratório sobre professores de inglês, os sete alunos se posicionaram com maturidade e clareza, mostrando-se capazes de realizar avaliações. Notei a incidência de processos mentais cognitivos no discurso das crianças tais como: achar, saber, imaginar, entender, perceber, pensar, prestar atenção, inventar, o que pode ilustrar a crença de que ensino e aprendizagem são baseados na cognição. Observei que os alunos avaliaram o professor de inglês muito mais no âmbito do julgamento quando comparado com as avaliações que realizaram da escola, nas quais o âmbito do afeto prevalece, como veremos a seguir. 


\section{3.}

\section{Nossas conversas exploratórias sobre o lugar-escola}

Nos excertos selecionados, os alunos conversam comigo a respeito da terceira Atividade Pedagógica com Potencial Exploratório, apresentada no capítulo 6, nas quais o tema gira em torno da escola como lugar de vínculos e de afetos. Todas as atividades, desenhos e textos, permaneceram em cima da mesa para que os alunos pudessem consultar ou manusear, caso assim desejassem. Somente Giovana observou e comentou as atividades dos colegas.

\section{Excerto 1 - Giovana - "eu notei que as flores tinham crescido"}

\begin{tabular}{|c|c|c|}
\hline $\begin{array}{l}155 \\
156\end{array}$ & Giovana & $\begin{array}{l}\text { esse daqui foi o do: Daniel né } \uparrow \text { ele desenhou } \\
\text { flores também né } \uparrow \text { e: ele deve ter achado } \\
\text { alguma coisa muito bonita nessas flores } \\
\text { violetas né } \uparrow \text { e ele fez um reflexo né } \uparrow \text { que } \\
\text { seria do sol, eu acho que ficou bonito } \\
\text { todos os desenhos eu gostei muito deles }\end{array}$ \\
\hline $\begin{array}{l}159 \\
160\end{array}$ & lara & $\begin{array}{l}\text { mas você sabe por que eles escolheram esse } \\
\text { lugares, cê tem alguma ideia? }\end{array}$ \\
\hline $\begin{array}{l}161 \\
162 \\
163 \\
164\end{array}$ & Gic & $\begin{array}{l}\text { então foi exatamente o que tinha dito que: } \\
\text { eles devem ser especiais para eles ou: >algo } \\
\text { do tipo< ou deve ter alguma coisa que chamou } \\
\text { a atenção deles }\end{array}$ \\
\hline $\begin{array}{l}165 \\
166\end{array}$ & Mar & $\begin{array}{l}\text { mas por que você acha que ninguém desenhou a } \\
\text { sala de aula? }\end{array}$ \\
\hline $\begin{array}{l}167 \\
168\end{array}$ & Gic & $\begin{array}{l}\text { é exatamente o que eu tava pensando né } \uparrow \\
((\text { risos }))\end{array}$ \\
\hline 169 & $\operatorname{ar}$ & $(($ risos $))$ \\
\hline $\begin{array}{l}170 \\
171 \\
172 \\
173 \\
174\end{array}$ & Gic & $\begin{array}{l}\text { ah: porque a sala de aula eu acho que para } \\
\text { eles a sala de aula é um lugar né } \uparrow \text { é um } \\
\text { lugar totalmente: é: : um lugar de estudos } \\
\text { né } \uparrow \text { e o esse-esse lugar né } \uparrow \text { é pra brincar né } \uparrow \\
\text { é: mais pra: >essas coisa assim< né } \uparrow\end{array}$ \\
\hline $\begin{array}{l}175 \\
176\end{array}$ & Ia & $\begin{array}{l}\text { pra você? por que cê não desenhou a sala de } \\
\text { aula? }\end{array}$ \\
\hline $\begin{array}{l}177 \\
178 \\
179 \\
180 \\
181 \\
182 \\
183 \\
184 \\
185 \\
186\end{array}$ & Gic & $\begin{array}{l}\text { eu não tenho a mínima ideia ( (risos)) eu acho } \\
\text { que ah eu sei porque esse-esse lugar né esse } \\
\text { banquinho aqui foi um lugar dos que eu mais } \\
\text { fiquei quanto eu era menor né } \uparrow \text { aí eu gosto } \\
\text { muito dele eu notei que as flores tinham } \\
\text { crescido e tudo né } \uparrow \text { e tudo e: porque às } \\
\text { vezes quando eu não queria brincar eu } \\
\text { sentava lá e ficava, eu pegava areia fazia } \\
\text { mont= fazia, desenha e tudo e ai eu gostava } \\
\text { gostei muito desse lugar né }\end{array}$ \\
\hline 187 & & \\
\hline
\end{tabular}


Este fragmento inicia-se com os comentários de Giovana sobre o desenho do Daniel. Na linha 157, a aluna realiza uma avaliação no campo da apreciação, "eu acho que ficou bonito" referindo-se ao desenho e aos detalhes por ela observados. O atributo "bonito", escolhido pela aluna, encontra-se na variável reação e está relacionado ao impacto emocional que o desenho causou em Giovana. Em seguida, a aluna realiza outra avaliação a respeito dos desenhos de outros colegas examinados, por ela, anteriormente em "todos os desenhos eu gostei muito deles" (linhas 157-158). Entendo que Giovana realiza uma avaliação de apreciação no campo estético e que sua reação é de agrado, conforme sua escolha do processo mental emotivo "gostei", reforçado pelo intensificador "muito". Suas escolhas lexicais parecem mostrar que, ao refletir sobre o trabalho dos colegas, Giovana se coloca como sujeito ativo, avaliando os desenhos através de sua percepção estética e experiência subjetiva.

Nas linhas 159-160, indago o motivo das escolhas dos lugares desenhados pelos colegas da turma. Na opinião de Giovana, os lugares selecionados "devem ser especiais para eles ou: >algo do tipo< ou deve ter alguma coisa que chamou a atenção deles" (linhas 162-164). Interpreto que ao escolher o léxico "especiais" (linha 162) para aos lugares escolhidos pelos colegas, Giovana não necessariamente se refere ao lugar físico, mas sim aos lugares de afeto, que despertam nos alunos sentimentos e emoções.

Nas linhas 170-174, Giovana elabora uma resposta para minha pergunta, justificando que os colegas não escolheram desenhar a sala de aula porque "é um lugar de estudos" (linha 170), ao passo que os locais selecionados são "pra brincar" (linha 173). Para Giovana, a escola parece estar dividida em dois espaços: o de estudar e o de brincar e que, de alguma forma, estes espaços não se misturam. Compreendo o que a aluna quis dizer da seguinte forma: o recreio é hora de brincar e acontece nos pátios da escola, em contrapartida, as tarefas de aula em livros e cadernos, as provas, os trabalhos em grupo, os vídeos, etc. acontecem dentro da sala de aula. Dessa forma, brincar não está associado à sala de aula, para Giovana, aluna do $5^{\circ}$ ano.

Quando questionei Giovana o porquê de não ter desenhado a sala de aula, a aluna elaborou a resposta visualizando seu desenho. Inicialmente, refere-se a um tipo de banco com estrutura de ferro e réguas de madeira, comumente encontrado 
em jardins. A aluna esclarece que "esse banquinho aqui foi um lugar dos que eu mais fiquei quanto eu era menor" (linhas 178-180) e acrescenta "eu gosto muito dele" (linhas 180-181), indicando o valor emotivo associado ao banco, o qual a remete aos anos iniciais de sua infância no ambiente escolar. É possível, então, pelas suas escolhas léxico-gramaticais, inferir que Giovana realiza um avaliação no campo do afeto explícito, o que mostra laços estabelecidos com o ambiente físico. Para a aluna, o banco passa a ser mais que um objeto de madeira para tornar-se um elemento importante que indica sua afeição pelo lugar.

Ainda se reportando ao seu desenho, nas linhas 181-182, Giovana se refere às flores "eu notei que as flores tinham crescido". O processo mental perceptivo, por ela escolhido, mostra que através de um olhar mais atento, Giovana pôde constatar que as plantas ao redor do banco haviam crescido e que, consequentemente, o número de flores havia aumentado. Giovana realiza uma avaliação no campo semântico da apreciação na variável reação. Dessa forma, a aluna ilustra seus afetos na apreciação. Giovana revela discursivamente vínculos emocionais com o mundo natural vivenciado por ela no quintal da escola (seção 6.3.).

Nas linhas 182-185, Giovana explica que "às vezes quando eu não queria brincar eu sentava lá e ficava, eu pegava areia fazia mont = fazia, desenha e tudo". Quando Giovana menciona o fato de não querer brincar parece estar se referindo à interação com outros colegas. Naqueles momentos, escolhia estar sozinha, por este motivo, "sentava lá e ficava" (linha 184), na verdade, brincando pois pegava areia, fazia montes, desenhava no chão e muito mais. Giovana recorda de momentos de introspecção, nos quais, mesmo cercada de outras crianças no pátio, escolhia brincar sozinha perto do banco de madeira.

Por fim, Giovana realiza um registro de sentimento positivo construído em relação ao lugar com a escolha do processo mental emotivo gostar, o qual a aluna conjuga no pretérito imperfeito e no pretérito perfeito "eu gostava gostei muito desse lugar" (linhas 185-186). O primeiro indica uma ação passada que continua no presente; o segundo indica uma ação passada e concluída. Giovana faz uso das duas conjugações verbais, seguidas do intensificador 
"muito", com uso do recurso paralinguístico de ênfase para expressar seus sentimentos de afeto explícito acerca do lugar mencionado e desenhado por ela.

Observei que Giovana, assim como seus colegas nos próximos excertos, parecem compreender a diferença entre residir e habitar um lugar (ORR, 2006a, 2006b), pois vivem uma relação íntima com o lugar-escola, valorizando a proximidade com a natureza.

\section{Excerto 2 - Theo - "eu gosto muito da horta"}

\begin{tabular}{|c|c|c|}
\hline $\begin{array}{l}123 \\
124\end{array}$ & Mara & $\begin{array}{l}\text { você pode me explicar como foi essa } \\
\text { atividade? }\end{array}$ \\
\hline $\begin{array}{l}125 \\
126 \\
127 \\
128\end{array}$ & Theo & $\begin{array}{l}\text { essa atividade cê falou pra gente: ir pra um } \\
\text { lugar: : mas ( ) acho que era isso né } \uparrow \text { aí } \\
\text { a gente tinha que desenhar né } \uparrow \text { >nosso lugar } \\
\text { favorito da escola< }\end{array}$ \\
\hline 129 & Mara & ${ }^{\circ}$ humhum $^{\circ}$ \\
\hline $\begin{array}{l}130 \\
131 \\
132 \\
133 \\
134 \\
135 \\
136 \\
137 \\
138 \\
139 \\
130\end{array}$ & Theo & $\begin{array}{l}\text { aí a gente foi lá pro: pátio da galinha né } \\
\text { que eu gostava muito da horta, a horta é um } \\
\text { lugar muito legal, é o único lugar assim que } \\
\text { eu: vejo: cultiva: : e tal porque eu: gos:to } \\
\text { de cozinhar e a gente precisa de tempero e: } \\
\text { é: alimento então a gente pega lá da horta, } \\
\text { eu gosto muito da horta, visito a horta o } \\
\text { tem:po todo e aí eu desenhei né } \uparrow \text { essa imagem } \\
\text { que mostra um pouco das folhas da palmeira, } \\
\text { um vaso de flo-flores aí aqui do lado já } \\
\text { parte um pouquinho pra plantação }\end{array}$ \\
\hline 141 & Mara & ${ }^{\circ}$ humhum ${ }^{\circ}$ \\
\hline 142 & Theo & e: aí aqui tem é:: a gra-gradezinha que: : \\
\hline $\begin{array}{l}143 \\
144\end{array}$ & Mara & [separa \\
\hline 145 & Theo & [é separa o pátio da horta] \\
\hline $\begin{array}{l}146 \\
147\end{array}$ & Mara & $\begin{array}{l}\text { aham então você diria que a horta é um dos } \\
\text { seus lugares favoritos na escola ou não? }\end{array}$ \\
\hline 148 & Theo & sim sim eu diria \\
\hline
\end{tabular}

Neste trecho, Theo se refere à Terceira Atividade Pedagógica com Potencial Exploratório e, inicialmente, explica como a mesma foi proposta e realizada pelo grupo. Nas linhas 137-140, Theo descreve seu desenho para mim, "essa imagem que mostra um pouco das folhas da palmeira, um vaso de flo-flores aí aqui do lado já parte um pouquinho pra plantação". É possível notar a atenção aos detalhes por ele observados na elaboração do desenho, o que parece refletir seu interesse pela natureza.

Theo realiza três avaliações explícitas, fazendo uso do processo mental emotivo gostar. Na primeira, "eu gostava muito da horta" (linha 131), 
Theo refere-se à horta da escola e reforça sua avaliação no campo de afeto positivo e explícito, com o uso do recurso paralinguístico de ênfase e o intensificador "muito". A segunda, "eu: gos:to de cozinhar e precisa de tempero" (linha 133-134), o aluno revela seu gosto pela culinária e associa o lugar-horta aos temperos usados no preparo de alimentos. Faz uso do recurso paralinguístico de prolongamento de vogal para enfatizar sua avaliação no campo do afeto positivo. A terceira avaliação, "eu gosto muito da horta, visito a horta o tem:po todo" (linhas 136-137), situa-se no campo do afeto, pois além de gostar, Theo visita, a horta. Acho que o que Theo quis dizer foi que ele frequenta, aprecia, e contempla a horta, o que seria bem diferente de passar pela horta, enquanto está na escola. A escolha de "० tem:po todo" (linhas 136-137) indica a frequência e, também, revela seus sentimentos pela horta. Theo mostra, discursivamente, afinidades, "vínculos emocionais e estéticos com o mundo natural" (CAPRA, 2006a, p. 180).

Nas linhas 131 e 132, em "a horta é um lugar muito legal", Theo realiza uma avaliação no campo da apreciação na variável reação, instanciada no afeto. O uso do recurso paralinguístico de ênfase no processo relacional, o intensificador "muito" e o atributo "legal", no sentido de bom, agradável ou especial revelam, a presença de afeto. Discursivamente, Theo faz escolhas que mostram suas afinidades pela horta e o quanto ele valoriza a oportunidade de vivenciar as cores, os cheiros e as texturas desse espaço no ambiente escolar. Assim como Giovana e os outros colegas, Theo parece habitar lugar-escola.

\section{Excerto 3 - Tito - "tem bastante areia"}

\begin{tabular}{|l|l|l|}
\hline 78 & Mara & >tá< cê pode me falar sobre essa outra \\
79 & & atividade, esse desenho que você fez? \\
\hline 80 & Tito & eu fiz também no pátio da galinha num lugar \\
81 & & um pouco diferente mas mesmo assim que tem \\
82 & & uma casa que: : bom que meus amigos aqui \\
83 & & tavam desenhando tem o Gaelgol o Breno e o: \\
84 & & Theo.. é eles tavam me desenhando, os \\
85 & & três me desenhando enquanto eu desenhava \\
86 & & eles três, eu gosto desse lugar também é um \\
87 & & lugar que cê pode se divertir, brincar, cê \\
88 & & pode subir aqui e ficar escondi:do, eu acho \\
89 & & boni:to \\
\hline 90 & Mara & ${ }^{\circ}$ humhum \\
\hline 91 & Tito & tem bastante areia é: \\
\hline
\end{tabular}


Neste excerto, Tito revê o desenho realizado na terceira Atividade Pedagógica com Potencial Exploratório e esclarece que desenhou a casa da árvore em dos pátios da escola, conhecido como pátio da galinha. Em seu desenho, Tito incluiu três colegas "tem ○ Gaelgol o Breno e o: : Theo" (linhas 8384). Nas linhas 84-86, Tito explica que "os três me desenhando enquanto eu desenhava eles três". Conforme pode ser observado nos desenhos apresentados no capítulo 6, Tito foi desenhado por Gael e Breno. Theo estava na casa da árvore para terminar o desenho que iniciou na horta, portanto Tito não aparece no desenho de Theo.

$\mathrm{Na}$ linha 86, em "eu gosto desse lugar", Tito expressa seus sentimentos em relação ao pátio e realiza uma avaliação autoral no campo semântico do afeto explícito. O uso do recurso paralinguístico de ênfase aumenta a gradação de seus sentimentos pelo lugar que desenhou. Em seguida, o aluno avalia o pátio como "um lugar que cê pode se divertir, brincar, cê pode subir aqui e ficar escondi:do" (linhas 86-88). Com a escolha de processos materiais que demandam movimento - "brincar, subir, ficar escondi:do" - é possível inferir que o pátio representa, para Tito, local de recreação, socialização e atividade física, onde ele pode correr, brincar de pique, subir e descer da casa da árvore. Mesmo o processo mental emotivo "divertir" parece relacionado a possibilidade de movimento nas brincadeiras realizadas no pátio. Nesse sentido, interpreto a avaliação de Tito a respeito do pátio como positiva e permeada de afeto. Diferentemente de Giovana e Theo que associam o mesmo pátio à possibilidade de contato com o mundo natural, Tito associa o pátio ao prazer de brincar.

$\mathrm{Na}$ linha 90, Tito acrescenta que o pátio "tem bastante areia". O uso do léxico intensificador "bastante" quantifica, e até mesmo qualifica o pátio como um espaço diferente dos outros. Assim, ter areia caracteriza o pátio como lugar diferente da quadra, do laboratório, da cantina, das salas de aula. A vida no pátio proporciona uma dinâmica singular. Enquanto na maioria dos lugares de aprendizagem, o aluno permanece sentado em uma cadeira, sem movimentos livres e amplos, no pátio a liberdade de movimentos é maior. Nos dois pátios de areia da escola é possível a troca sensorial com o meio natural - 
manusear a areia, brincar com folhas secas, galhos e flores, observar insetos, cavar e construir. Para alguns, o pátio pode significar muita areia no tênis, risco de quedas e arranhões, mãos sujas, uniforme sujo. Para mim, o pátio é local de aprendizagens; lugar de desenvolvimento cognitivo, motor, social e emocional; espaço de atividades lúdicas, de criatividade e contato com a natureza.

Nas linhas 88-89, Tito realiza uma avaliação positiva no campo da apreciação "eu acho boni:to", referindo-se ao pátio. Sua avaliação explícita nos remete à estética visual do pátio. Na minha análise, o recurso paralinguístico de alongamento de vogal indica intensidade alta.

Discursivamente, Tito expressa seu envolvimento afetivo com o lugarescola, o que é compartilhado pelos seus colegas.

\section{Excerto 4 - Breno - "era um ângulo bom"}

\begin{tabular}{|c|c|c|}
\hline $\begin{array}{l}30 \\
31\end{array}$ & Mara & $\begin{array}{l}\text { cê fez esse ou:tro desenho, cê consegue } \\
\text { lembrar? }\end{array}$ \\
\hline $\begin{array}{l}32 \\
33\end{array}$ & Breno & $\begin{array}{l}\text { sim: eu desenhei de cima da casa da árvore } \\
\text { do pátio da gali:nha }\end{array}$ \\
\hline 34 & Mara & por que: que: você escolheu esse lugar? \\
\hline $\begin{array}{l}35 \\
36\end{array}$ & Breno & $\begin{array}{l}\text { também era um ângulo bom: e: } \\
\text { também tava desenhando meus amigos }\end{array}$ \\
\hline 37 & Mara & você lembra quem são os amigos? \\
\hline 38 & Breno & sim eu desenhei o Daniel e o Tito \\
\hline 39 & Mara & o que que o Daniel tava fazendo? \\
\hline 40 & Breno & desenhando o mesmo que eu \\
\hline 41 & Mara & o Daniel desenhando o mesmo que você e: \\
\hline $\begin{array}{l}42 \\
43\end{array}$ & Breno & Tito também?] \\
\hline $\begin{array}{l}44 \\
45 \\
46 \\
47\end{array}$ & Mara & 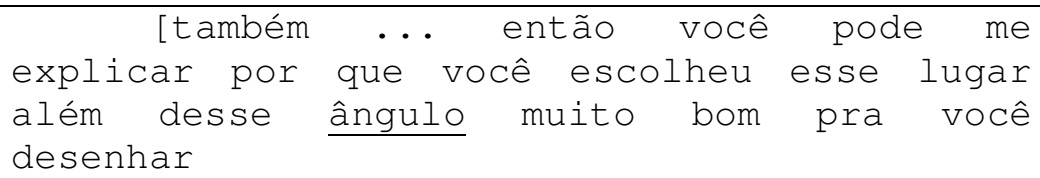 \\
\hline $\begin{array}{l}48 \\
49 \\
50 \\
51\end{array}$ & Breno & $\begin{array}{l}\text { eu gosto, eu gostei do jeito que eu tava } \\
\text { vendo ... também assim ... eu também achei } \\
\text { de um jeito bom ... a-a vista minha pra } \\
\text { baixo }\end{array}$ \\
\hline 52 & Mara & sentendi< por que você escolheu esse lugar? \\
\hline $\begin{array}{l}53 \\
54\end{array}$ & Breno & $\begin{array}{l}\text { eu gosto dele, eu gosto do jeito como eu } \\
\text { fico no lugar pra desenhar }\end{array}$ \\
\hline
\end{tabular}

A respeito da terceira Atividade Pedagógica com Potencial Exploratório, nas linhas 32-33, Breno faz referência ao seu desenho e esclarece que se posicionou no alto da casa da árvore, localizada no pátios. $\mathrm{Na}$ tentativa de justificar sua escolha pelo lugar, Breno informa que "era um ângulo bom:" 
(linha 35), ou seja, o lugar possibilitava uma visão ampla do pátio. Breno esclarece, nas linhas 49-51 "achei de um jeito bom ... a-a vista minha pra baixo", o que indica sua intenção de fazer um desenho observando a paisagem, porém vista de cima para baixo.

Nas linhas 48-49, Breno realiza uma avaliação explícita e com voz autoral "eu gosto, eu gostei do jeito que eu tava vendo". A escolha do processo mental emotivo pode indicar uma avaliação de afeto institucionalizada no campo da apreciação, pois envolve o aspecto estético, que naquele momento era a paisagem do pátio admirada pelo aluno.

$\mathrm{Na}$ linha 52, pergunto pela terceira vez porquê Breno havia escolhido aquele lugar e a resposta foi "eu gosto dele, eu gosto do jeito como eu fico no lugar pra desenhar" (linhas 53-54). O "jeito" (linha 53) ao qual Breno se refere não deve ser em pé na casa da árvore, segurando o lápis e o papel apoiado em um caderno, mas sim a oportunidade de estar ao ar livre em um dia de sol cercado de árvores - 3 mangueiras, 1 cajueiro, 1 goiabeira, 1 caquizeiro, e muitas bananeiras. Em sua visão no alto da casa na árvore, Breno pôde contemplar e admirar a paisagem por outro "ângulo" (linha 35). Diante disso, em minha análise, entendo que nas linhas 53 e 54, Breno realiza uma avaliação positiva de afeto implícito pelo lugar-escola que habita. Tal como os colegas, Breno expressa sua ligação afetiva com o ambiente natural da escola.

\section{Excerto 5 - Daniel - "as flores, as plantas"}

\begin{tabular}{|l|l|l|l|}
\hline 04 & Mara & por que você escolheu esse lugar você \\
05 & & lembra? então tá, vai fala & \\
\hline 06 & Daniel & é:: eu escolhi porque é: é: um local muito \\
07 & & bonito é: lá no pátio da galinha e: eu \\
08 & & escolho porque é: tem várias flores, achei \\
09 & & bem bonito eu também achei muito legal de \\
10 & & desenhar isso ai:: por isso que eu escolhi \\
\hline 11 & Mara & você falou que o local é bonito o que é \\
12 & & bonito no pátio? o que cê acha bonito? & \\
\hline 13 & Daniel & as flores, as plantas .. \\
\hline 14 & Mara & que mais tem lá no pátio? \\
\hline 15 & Daniel & as cores \\
\hline 16 & Mara & cores? cê gosta das cores do pátio? então me \\
\hline 17 & & fala alguma cor que você gosta? \\
\hline 18 & Daniel & o verde \\
\hline 19 & Mara & ah entendi e tem algum outro lugar na escola \\
\hline 20 & & que você goste, que seja especial pra você? \\
\hline 21 & Daniel & sim \\
\hline
\end{tabular}




\begin{tabular}{|c|c|c|}
\hline 22 & Mara & qual? \\
\hline 23 & Daniel & ... o pátio da frente \\
\hline 24 & Mara & por quê? \\
\hline $\begin{array}{l}25 \\
26\end{array}$ & Daniel & $\begin{array}{l}\text { é:: um local muito grande, dá: tem espaço } \\
\text { pra brincar ... é bem legal }\end{array}$ \\
\hline 27 & Mara & algum outro lugar? \\
\hline 28 & Daniel & a quadra \\
\hline $\begin{array}{l}29 \\
30\end{array}$ & Mara & $\begin{array}{l}\text { a quadra }((r i s o s)) \\
\text { perguntar porquê né } \uparrow\end{array}$ \\
\hline 31 & Daniel & aham \\
\hline 32 & Mara & por que você gosta da quadra? \\
\hline $\begin{array}{l}33 \\
34\end{array}$ & Daniel & $\begin{array}{l}\text { ((risos)) porque: : pra: jogar } \\
\text { vários esportes }\end{array}$ \\
\hline
\end{tabular}

Das linhas 4-18, o tema da interação é a terceira Atividade Pedagógica com Potencial Exploratório. Daniel realiza avaliações de seu próprio desenho, justificando sua escolha da seguinte maneira: "eu escolho porque tem várias flores" (linha 8); "achei bem bonito" (linhas 8-9); "eu também achei muito legal de desenhar" (linhas 9-10). Suas avaliações envolvem o aspecto estético, a forma como Daniel aprecia "as flores, as plantas" (linha 13) e "as cores" (linha 15) do pátio, o qual ele avalia como "um local muito bonito" (linhas 6-7). O atributo "bonito" (linhas 7 e 9) foi usado duas vezes precedido pelos intensificadores "bem" (linha 9) e "muito" (linha 6). Daniel realiza avaliações positivas no campo da apreciação institucionalizadas no afeto, pois Daniel parece mostrar discursivamente a importância dos vínculos emocionais com o mundo natural (CAPRA, 2006a), o que é compartilhado pelos colegas do grupo.

Em seguida, pergunto para Daniel sobre outros lugares que ele gosta na escola. Ele menciona "o pátio da frente" (linha 15) e "a quadra" (linha 28). O pátio da frente "é:: um local muito grande, dá: tem espaço pra brincar ... é bem legal" (linhas 25-26). Daniel avalia o pátio positivamente, fazendo uso dos atributos "grande" (linha 25) e "legal" (linha 26). Tal avaliação encontra-se no campo da apreciação na categoria reação (cf. quadro 3, seção 4.3.1.). Para Davi, a quadra está relacionada ao futebol e outros esportes, conforme explica" ((risos)) porque: : pra: jogar futebol, vários esportes" (linha 33-34). Esta avaliação realizada por Daniel encontra-se no campo semântico do afeto marcada pelo recurso paralinguístico do riso. $\mathrm{Na}$ linha 29 , o meu riso indica que eu sei porquê a quadra 
é um lugar especial para ele. Avalio, então, o riso como uma forma de partilhar com Daniel meu conhecimento prévio acerca da paixão que ele sente por esportes, principalmente, futebol. Na linha 33, Daniel ri antes de falar algo que nós dois já sabemos. Nesse fragmento, o recurso paralinguístico do riso encontra-se ligado ao afeto, assuntos do coração (cf. affairs of the heart, MARTIN, 2003, p. 150).

Assim como Giovana e Theo, é possível notar que Daniel parece valorizar a proximidade com a natureza e as vivências em espaços ao ar livre, possíveis na escola. O aluno revela também seu encantamento pelas cores, flores e plantas que compõem o ambiente da escola.

\section{Excerto 6 - Gael - "é muito bom passar o recreio lá"}

\begin{tabular}{|c|c|c|}
\hline $\begin{array}{l}18 \\
19\end{array}$ & Mara & $\begin{array}{l}\text { mas: por que você escolheu esse lugar aqui } \\
\text { da escola }\end{array}$ \\
\hline $\begin{array}{l}20 \\
21 \\
22 \\
23 \\
24 \\
25 \\
26 \\
27 \\
28 \\
29 \\
30 \\
31\end{array}$ & Gael & $\begin{array}{l}\text { é: : eu escolhi é: porqu é por causa de: } \\
\text { duas coisas porque a casinha da árvore é: é } \\
\text { dá pra ver uma grande parte da escola dá pra } \\
\text { vê uma parte bonita da escola dali de cima e } \\
\text { tipo é um lugar alto e tipo você senta no } \\
\text { chão pra vê pra escrever pra desenhar é um } \\
\text { lugar alto e ai dá pra vê melhor e também } \\
\text { porque eu queria desenhar o pátio da galinha } \\
\text { onde eu brincava muito ano retrasado em } 2016 \\
\text { eu fazia quase todo recreio do meu bilingue } \\
\text { lá e eu: é um lugar que eu sempre gostei de } \\
\text { brincar, de jogar futebol }\end{array}$ \\
\hline $\begin{array}{l}32 \\
33\end{array}$ & Mara & $\begin{array}{l}\text { é: tem algum outro lugar da escola que você } \\
\text { goste? }\end{array}$ \\
\hline $\begin{array}{l}34 \\
35 \\
36 \\
37 \\
38 \\
39 \\
40\end{array}$ & Gael & $\begin{array}{l}\text { sim né } \uparrow \text { eu acho que todos os meninos a } \\
\text { quadra ((risos)) e o pátio da frente é: } \\
\text { passei todos os anos brincando lá recreio } \\
\text { quase todos os dias eu ia lá brincava de } \\
\text { pique pega, pique ajuda, pique alto com meus } \\
\text { amigos e é um lugar bem grande então dá pra } \\
\text { brincar bem lá }\end{array}$ \\
\hline $\begin{array}{l}41 \\
42\end{array}$ & Mara & $\begin{array}{l}\text { além de brincar } \\
\text { fazer na escola? }\end{array}$ \\
\hline $\begin{array}{l}43 \\
44 \\
45 \\
46 \\
47 \\
48\end{array}$ & Gael & $\begin{array}{l}\text { ah estudar eu gosto de: : estudar, os } \\
\text { professores são bem legais dá pra é: : o modo } \\
\text { que eles botam pra você estudar não é um } \\
\text { modo chato que você fica falando "ah vô ter } \\
\text { que estudar", é legal eles passam o estudo } \\
\text { de um modo legal é } \downarrow\end{array}$ \\
\hline $\begin{array}{l}49 \\
50 \\
51\end{array}$ & Mara & $\begin{array}{l}\text { e: assim tem mais alguma coisa que você } \\
\text { queria falar sobre a escola? o espaço da } \\
\text { escola como umas coisa que= }\end{array}$ \\
\hline $\begin{array}{l}52 \\
53 \\
54\end{array}$ & Gael & 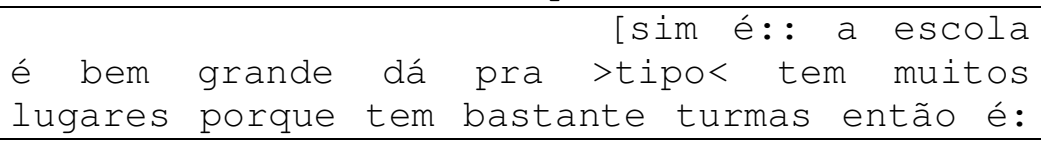 \\
\hline
\end{tabular}




\begin{tabular}{|l|l|l|l|}
\hline 55 & & dá pra brincar lá todas as turmas se botar \\
56 & & todas as turmas lá pra brincar vai ficar um \\
57 & & pouco apertado mas não vai ficar tão \\
58 & & apertado assim a escola é bem grande é um \\
59 & & espaço bom é isso \\
\hline 60 & Mara & o que você chama de espaço bom? \\
\hline 61 & Gael & um espaço com ar livre que você possa correr \\
62 & & <brincar> é ter um espaço também que dá pra \\
63 & & sentar <conversar com amigo> espaço que dá \\
64 & & pra jogar, embaixo da árvore que até tem um \\
65 & & banco que: é legal sentar lá e conversar com \\
66 & & amigo, é muito bom passar o recreio lá \\
\hline 67 & Mara & ${ }^{\circ}$ entendi ${ }^{\circ}$ & \\
\hline
\end{tabular}

Neste trecho, das linhas 20-31, Gael cita dois motivos que o levaram a selecionar o lugar por ele desenhado para a terceira Atividade Pedagógica com Potencial Exploratório. Primeiro, cita que a casa da árvore por ser "um lugar alto" (linhas 24 e 26), "dá pra ver uma grande parte da escola" (linhas 21 e 22). Segundo, Gael esclarece que "queria desenhar o pátio da galinha" (linha 27), local onde costumava brincar durante o "recreio do bilíngue" (linha 29). A seguir, o aluno realiza uma avaliação de afeto positivo, marcada pelo processo mental emotivo 'gostar' em relação ao pátio escolhido por ele, afirmando que "é um lugar que eu sempre gostei de brincar, de jogar futebol" (linhas 30-31).

Nas linhas 34-40, Gael esclarece que além da quadra, gosta do pátio da frente, onde passa seus recreios na companhia dos amigos. O pátio "é um lugar bem grande então dá pra brincar bem lá" (linhas 39-40). Gael, tal como Daniel, no excerto 5, revelou apreciar a quadra e o pátio da frente pelos mesmos motivos: a quadra porque gostam de esportes, e o pátio da frente por ser amplo.

Quando pergunto para Gael o que ele quer dizer com espaço "bom" (linha 60), ele responde "um espaço com ar livre" (linha 61). No meu entendimento, Gael quis dizer um espaço aberto, sem paredes ou muros, para vislumbrar o céu. E em seguida, relaciona o que é possível fazer no pátio: "correr" (linha 61), "<brincar>" (linha 62), "sentar <conversar com amigo>" (linha 63), "jogar" (linha 64). Segundo Tuan (2013, p. 86), "o mundo nos parece espaçoso e amistoso quando concilia nossos desejos, e limitado quando eles são frustrados". Nesse viés, independente de quantos metros quadrados a 
escola reserva para os pátios abertos, é possível inferir que Gael sente-se à vontade e familiarizado com os lugares da escola, o que concilia com seus desejos de aluno de 10 anos de idade.

Ao mencionar um banco de madeira que fica embaixo de uma árvore (6465), Gael realiza uma avaliação no campo da apreciação carregada de afeto: "é legal sentar lá e conversar com amigo, é muito bom passar o recreio lá". (linhas 65-66). Além de mostrar familiaridade com os espaços da escola, Gael valoriza a oportunidade de estar em contato com a natureza e realça a escola como lugar de afetos, em relação ao lugar e às pessoas que a habitam. Gael realiza uma avaliação positiva do lugar-escola impregnada de afeto.

Retomando à linha 43, Gael esclarece que gosta de estudar e, em seguida, realiza uma avaliação positiva no campo do julgamento em relação ao comportamento e à capacidade pedagógica dos professores - "o modo que eles botam pra você estudar não é um modo chato que você fica falando "ah vô ter que estudar", é legal eles passam o estudo de um modo legal é $\downarrow$ " (linhas 44-48). Gael atribui aos professores da escola a habilidade de envolver os alunos nos conteúdos para que se desenvolvam como agentes de seus estudos e de suas aprendizagens. Essa noção é também verbalizada por Bruna, a seguir.

\section{Excerto 7 - Bruna - "meu lugar favorito da escola mesmo é a sala de aula"}

\begin{tabular}{|c|c|c|}
\hline $\begin{array}{l}133 \\
134 \\
135\end{array}$ & Mara & $\begin{array}{l}\text { O que você destaca aqui nesta escola que cê } \\
\text { falou é uma escola bem legal mas o que cê } \\
\text { acha que é:: }\end{array}$ \\
\hline 136 & $\mathrm{Br}$ & [mais legal? \\
\hline 137 & Mara & [é: assim muito bom? \\
\hline $\begin{array}{l}138 \\
139 \\
140 \\
141 \\
142\end{array}$ & Br & $\begin{array}{l}\text { eu gosto muito dos professores né } \uparrow \text { a Glória, } \\
\text { tenho >tipo< muito carinho por todos os } \\
\text { professores quanto a Glória, o Renan, a } \\
\text { Laura ((tosse)) o Tales, sei que todo mundo } \\
\text { tem certas aulas favoritas }\end{array}$ \\
\hline 143 & Ma & ${ }^{\circ}$ humhum ${ }^{\circ}$ \\
\hline $\begin{array}{l}144 \\
145 \\
146 \\
147\end{array}$ & Bruna & $\begin{array}{l}\text { a minha é arte né } \uparrow \text { educação física então } \\
\text { acho que os professores são maravilho:sos } \\
\text { também tem a questão do aprendizado eles } \\
\text { fazem tudo muito bem é:: ((tosse)) }\end{array}$ \\
\hline $\begin{array}{l}148 \\
149\end{array}$ & Mara & $\begin{array}{l}\text { é: tem algum lugar favorito? cê tem algum } \\
\text { lugar favorito aqui na escola? }\end{array}$ \\
\hline $\begin{array}{l}150 \\
151\end{array}$ & Bruna & $\begin{array}{l}\text { 'aqui na escola eu gosto muito da parte da } \\
\text { comi:da né } \uparrow \text { na cantina }\end{array}$ \\
\hline
\end{tabular}




\begin{tabular}{|c|c|c|}
\hline 152 & Mara & ah a cantina ((risos)) \\
\hline $\begin{array}{l}153 \\
154\end{array}$ & Bruna & $\begin{array}{l}\text { também sinto muita falta da comida da escola } \\
\text { né } \uparrow \text { da comida mesmo arroz feijão }\end{array}$ \\
\hline 155 & Mara & humhum \\
\hline $\begin{array}{l}156 \\
157 \\
158 \\
159 \\
160 \\
161 \\
162 \\
163\end{array}$ & Bruna & $\begin{array}{l}\text { agora tô tendo que comer em casa ((tosse)) } \\
\text { também tenho uma coisa com a quadra ainda } \\
\text { mais que eu gosto muito de vôlei por } \\
\text { incrível que pareça futebol então acho que a } \\
\text { quadra é um bom lugar mas meu lugar } \\
\text { fa:vorito da escola mes:mo acho que é a sala } \\
\text { de aula a gente sempre tá aprendendo coisas } \\
\text { novas assim é maravilhoso }\end{array}$ \\
\hline 164 & Mara & ${ }^{\circ}$ que $\mathrm{bom}^{\circ}$ \\
\hline
\end{tabular}

Nas linhas 133-135, deste excerto, minha intenção era elaborar uma pergunta para que Bruna falasse sobre a escola e o desenho do lugar da escola que havia escolhido, porém a aluna associa o que há de bom na escola aos professores. Sem mencionar seu desenho. É possível perceber, na linha 138, que com a escolha do processo mental emotivo, acrescido de um intensificador, a aluna mostra seus sentimentos ao expressar "eu gosto muito dos professores", realizando uma avaliação positiva no campo do afeto. Em seguida, nas linhas 139-140, a aluna completa seu pensamento afirmando "tenho >tipo< muito carinho por todos os professores", indicando afeto explícito marcado no léxico "carinho" (linha 139) e intensificado pelo uso de "muito" (linha 139). Ter carinho ou sentir carinho significa ter apreço, consideração, afeição, cuidado; significa querer bem, criar laços, manifestar afeto. Bruna revela seus sentimentos em relação aos professores de forma explicita, pois além de gostar, tem carinho por todos, realizando avaliações positivas no campo do afeto.

Considero relevante apontar que no fragmento das linhas 138-141, Bruna menciona os professores de Artes (Glória), Música (Renan), Informática (Laura) e Educação Física (Tales), cujos os nomes foram aqui substituídos por nomes fictícios. Bruna esclarece que gosta de Artes (linha 144) e da professora de Artes Glória (linhas 138 e 140). A aluna conclui com uma avaliação positiva na linha 145, "acho que os professores são maravilho:sos", atributo que pode significar excelentes ou extraordinários. Bruna realiza, assim, uma avaliação no campo do julgamento de normalidade - professores são especiais? (cf. quadro 3, seção 4.3.1.), que analiso como institucionalizada no afeto. 
Quando questiono sobre um lugar favorito na escola, Bruna menciona três: a "cantina" (linha 151), a "quadra" (linha 157) e a "sala de aula" (linhas 161-162). Cada preferência é justificada pela aluna da seguinte forma: a cantina/refeitório porque aprecia a "comida" (linhas 151, 153 e 154); a quadra porque gosta de jogar "vôlei" e "futebol" (linhas 158-159); e a sala de aula porque "tá aprendendo coisas novas" (linhas 162-162)'. Apesar de ter mencionado a cantina e a quadra, a aluna especifica que a sala de aula é seu lugar de preferência e lança mão do recurso de ênfase e do recurso paralinguístico de alongamento de vogal para se expressar, nas linhas 160-161, "meu lugar fa:vorito da escola mes:mo", o que reforça sua avaliação positiva no campo do afeto.

Segundo as escolhas que realiza, Bruna indica somente a sala de aula como lugar de aprendizagem. Assim, no meu entendimento, Bruna parece associar a cantina/refeitório ao prazer de comer, não identificando que o almoço faz parte do Programa Bilíngue e é acompanhado pelas professoras em uma tentativa de criar um ambiente de interações com o uso da língua inglesa, portanto, um local de aprendizagens. O outro ambiente mencionado pela aluna é a quadra. Entendo a quadra como lugar de aprendizagens múltiplas, de práticas lúdicas, de elaboração de regras específicas, de desenvolvimento da coordenação motora e do equilíbrio, de desenvolvimento social que envolve cooperação e integração. Dessa forma, acho pertinente acrescentar que a quadra escolar não deveria ser associada aos esportes e a competição somente, mas à um local de aprendizagens. Tanto a cantina/refeitório quanto a quadra parecem ser, para Bruna, locais ligados ao lúdico, enquanto a sala de aula parece estar associada à formação intelectual e cognitiva do aluno. Pelas escolhas realizadas, a aluna mostra valorizar mais a sala de aula, onde as aprendizagens ocorrem, segundo ela. Essa postura parece ser compartilhada por seus colegas.

Em seguida, Bruna realiza uma avaliação positiva no campo da apreciação institucionalizada no afeto, parecendo indicar que o ato de aprender "coisas novas assim é maravilhoso" (linhas 162-163). Essa avaliação me permite entender que a aluna valoriza o ensino e a aprendizagem que acontecem no cotidiano da sala de aula. Assim como seus colegas, Bruna parece valorizar os espaços da escola. 


\subsection{1. \\ Meus entendimentos}

Como já mencionado anteriormente, alicerçando esta dissertação encontram-se os princípios da Prática Exploratória (ALLWRIGHT; HANKS, 2009), os quais guiam minha postura como pesquisadora e professora praticante por entender que a qualidade de vida (GIEVE; MILLER, 2006) está relacionada aos afetos, às crenças, às emoções que movimentam as relações interpessoais no ambiente escolar.

A oportunidade de refletir conjuntamente sobre a terceira Atividade Pedagógica com Potencial Exploratório me permite o entendimento de que, além da importância das relações interpessoais no contexto pedagógico, os alunos participantes valorizam a proximidade com a natureza, as árvores, as plantas e as flores. Nas palavras de Orr (2006a, 121), “os lugares são laboratórios de diversidade e complexidade, misturando as funções sociais e os processos naturais". As vivências com a natureza no espaço escolar possibilitam a construção de vínculos emocionais e estéticos (CAPRA, 2006a) capazes de ativar a criatividade, a imaginação e o encantamento (LOUV, 2005) nos participantes desta pesquisa.

É possível perceber, ao longo deste capítulo, que os alunos participantes, impregnados das marcas do lugar-escola que habitam e conhecedores de sua geografia, aproveitam os espaços da escola para brincar, correr, sentar em um banco embaixo de uma árvore, e para ser feliz. Segundo Orr (ibidem), "o lugar tem uma história humana e um passado geológico; ele é parte de um ecossistema com uma variedade de microssistemas, é uma paisagem com uma flora e uma fauna particulares". Assim, o lugar-escola está ligado àqueles que o habitam por incontáveis vínculos de afeto.

\section{4.}

\section{Nossas conversas exploratórias sobre a participação na pesquisa}

A Prática Exploratória possibilita a interseção entre ensino, aprendizagem e pesquisa em uma tentativa de unir a pesquisa do praticante com a pedagogia (ALLWRIGHT, 2001). Dessa forma, o professor-praticante pode pesquisar seu próprio contexto em conjunto com seus alunos. A proposta investigativa e 
reflexiva da Prática Exploratória nos posicionou como agentes de nossas buscas por maiores entendimentos a respeito de nossas questões situadas e localizadas, no contexto do Programa Bilíngue da escola. Nas interações destacadas, o foco foi a participação dos alunos na dissertação e como cada um entende sua colaboração e contribuição na pesquisa, ou seja, como se entendem como praticantes exploratórios.

Nos excertos a seguir, os alunos participantes discorrem sobre seus sentimentos e suas impressões em relação à pesquisa. Perguntei diretamente para os alunos como se sentiam participando da pesquisa, exceto para Giovana, que espontaneamente, verbalizou sua opinião, já no final de nossa conversa exploratória.

\section{Excerto 1 - Giovana - "eu amei fazer esse trabalho"}

\begin{tabular}{|l|l|llll|}
\hline 223 & Giovana & $\begin{array}{l}\text { não sei, cada teacher é especial do seu } \\
\text { jeito né } \uparrow\end{array}$ & & & \\
\hline 225 & Mara & <isso mesmo> então você quer falar mais \\
226 & & alguma coisa? não? & & \\
\hline 227 & Giovana & eu amei fazer esse trabalho ((risos)) & \\
\hline 228 & Mara & ah ... que bom Giovana, muito obrigada & \\
\hline
\end{tabular}

Apesar de não ter perguntado diretamente para Giovana sobre sua participação na pesquisa, a aluna posiciona-se, na linha 227, com voz autoral "eu amei fazer esse trabalho". A escolha do processo mental emotivo 'amar', acrescido do recurso paralinguístico de ênfase parecem indicar uma avaliação com gradação de alta força no campo do afeto. Outro recurso utilizado pela aluna foi o riso, ou seja, Giovana falou rindo, o que traz emoção e espontaneidade à sua maneira de se expressar. Interpreto, dessa forma, que Giovana avalia positivamente sua participação e seu envolvimento no processo de construção da pesquisa.

\section{Excerto 2 - Theo - "eu acho que eu tô colaborando um pouco sim"}

\begin{tabular}{|l|l|l|l|}
\hline 05 & Mara & $\begin{array}{l}\text { é como você se sente participando da } \\
\text { pesquisa? }\end{array}$ & \\
\hline 07 & Theo & muito feliz >bem feliz< \\
\hline 08 & Mara & por quê? \\
\hline 09 & Theo & porque: é: um trabalho né $\uparrow$ que eu vou tá com \\
10 & & meus amigos e pra mim uma coisa que me deixa \\
11 & & feliz é tá com meus amigos então tô muito \\
12 & & feliz \\
\hline
\end{tabular}




\begin{tabular}{|c|c|c|}
\hline $\begin{array}{l}13 \\
14 \\
15\end{array}$ & Mara & $\begin{array}{l}\text { >que bom< qual é sua participação na } \\
\text { pesquisa? cê acha que cê está colaborando? } \\
\text { como que você está participando? }\end{array}$ \\
\hline 16 & Theo & eu acho que eu tô colaborando um pouco sim个 \\
\hline 17 & Mara & um pouco, como? \\
\hline 18 & Theo & tipo ... >pera ai< ... \\
\hline $\begin{array}{l}19 \\
20 \\
21\end{array}$ & Mara & $\begin{array}{l}\text { o que: : assim qual a sua colaboração? qual a } \\
\text { sua participação? você se sente participando } \\
\text { da pesquisa? }\end{array}$ \\
\hline 22 & Theo & ah me sinto bem participando \\
\hline $\begin{array}{l}23 \\
24 \\
25\end{array}$ & Mara & $\begin{array}{l}\text { então mas fazendo o quê? o que você está } \\
\text { fazendo pra participar da pesquisa? hoje é } \\
\text { um dia que você está participando? }\end{array}$ \\
\hline 26 & The & é \\
\hline $\begin{array}{l}27 \\
28\end{array}$ & Mara & $\begin{array}{lll}\text { então que mais você } \\
\text { participar? }\end{array}$ \\
\hline 29 & Theo & ...ah... fazendo os trabalhos né $\uparrow$ \\
\hline
\end{tabular}

Neste trecho, Theo afirma que se sente "muito feliz >bem feliz<" (linha 7) participando da pesquisa, realizando uma avaliação positiva no campo do afeto, indicada pelo atributo "feliz" repetido duas vezes. A escolha dos recursos de gradação de força realizada nos intensificadores "muito" e "bem" assim como a escolha do léxico "feliz" reforçam o aspecto positivo da sua avaliação no campo do afeto, na linha 7.

Nas linhas 9-12, Theo explica que a pesquisa é "um trabalho né $\uparrow$ que eu vou tá com meus amigos e pra mim uma coisa que me deixa feliz é tá com meus amigos". O aluno quis dizer que a pesquisa envolve tanto as oportunidades de aprendizado quanto as oportunidades de aproximação com os colegas. Para Theo, mais que um trabalho, a pesquisa parece ser um evento social, no qual os alunos compartilham, interagem e convivem. Nas linhas 11-12, ao esclarecer "então tô muito feliz", o aluno realiza uma avaliação positiva no campo do afeto em relação às emoções que sente com a integração dos participantes da pesquisa.

$\mathrm{Na}$ linha 16, Theo responde às minhas indagações, afirmando que "eu acho que eu tô colaborando um pouco sim". A redução da força avaliativa ocorre com a escolha de "um pouco". Quando pergunto, na linha 17, "um pouco, como?" Theo não consegue elaborar uma resposta, dizendo apenas "tipo ... >pera ai< ..." (linha 18). E somente, na linha 29, responde "ah fazendo os trabalhos né $\uparrow "$. Diferentemente de Giovana, Theo parece entender sua participação na pesquisa como um trabalho escolar. 
Apesar de minhas perguntas, o aluno não elaborou com profundidade, nesse fragmento, acerca de sua participação nas Atividades Pedagógicas com Potencial Exploratório, durante as conversas exploratórias, e as aulas também. Entendo, então, pelas suas escolhas léxico-gramaticais, que Theo não se posicionou como praticante e coautor da dissertação, como fizeram seus colegas do grupo.

\section{Excerto 3 - Tito - "mas a gente também tá se ajudando"}

\begin{tabular}{|c|c|c|}
\hline $\begin{array}{l}01 \\
02\end{array}$ & Mara & $\begin{array}{l}\text { como você se sente participando dessa } \\
\text { pesquisa? }\end{array}$ \\
\hline $\begin{array}{l}03 \\
04 \\
05 \\
06 \\
07 \\
08\end{array}$ & Tito & $\begin{array}{l}\text { eu acho legal essa pesquisa assim porque: } \\
\text { <bom> porque a gente tá ajudando você um } \\
\text { pouco mas a gente também tá se ajudando, a } \\
\text { gente tá relembrando o que a gente fez é: } \\
\text { antes, a gente está pensando mais um pouco } \\
\text { nisso, é isso que eu acho }\end{array}$ \\
\hline $\begin{array}{l}09 \\
10 \\
11 \\
12\end{array}$ & Mara & $\begin{array}{l}\text { O que você pensa sobre ter algumas } \\
\text { atividades suas tipo desenhos as coisas que } \\
\text { você escreveu sabendo que outras pessoas vão } \\
\text { ler o que você pensa sobre isso? }\end{array}$ \\
\hline $\begin{array}{l}13 \\
14 \\
15 \\
16\end{array}$ & Tito & $\begin{array}{l}\text { ah eu penso eu penso que é legal porque se } \\
\text { eu caprichar e eu capricho eu sei que as } \\
\text { pessoas podem gostar da minh= dos meus } \\
\text { desenhos diferentes }\end{array}$ \\
\hline 17 & Mara & aham \\
\hline $\begin{array}{l}18 \\
19\end{array}$ & Tito & $\begin{array}{l}\text { ou dos meus trabalhos essas coisas eu acho } \\
\text { legal }\end{array}$ \\
\hline $\begin{array}{l}20 \\
21 \\
\end{array}$ & Mara & $\begin{array}{l}\text { qual a importância da sua colaboração da sua } \\
\text { participação na pesquisa? }\end{array}$ \\
\hline 22 & Tito & cara isso eu não tenho muita ideia \\
\hline 23 & Mara & ${ }^{\circ}$ humhum ${ }^{\circ}$ \\
\hline $\begin{array}{l}24 \\
25 \\
24 \\
25\end{array}$ & Tito & $\begin{array}{l}\text { pra mim todo mundo é uma parte importante } \\
\text { mas não consigo reconhecer qual parte } \\
\text { importante a pessoa é mas uma coisa é certa } \\
\text { é importante }\end{array}$ \\
\hline $\begin{array}{l}26 \\
27 \\
\end{array}$ & Mara & $\begin{array}{l}\text { mas você tem alguma ideia hoje do que vai } \\
\text { ser essa pesquisa? }\end{array}$ \\
\hline 28 & Tito & ((gesto com a cabeça)) \\
\hline 29 & Mara & não? \\
\hline 30 & Tito & não tenho \\
\hline
\end{tabular}

Neste excerto, Tito realiza avaliações acerca de sua participação na pesquisa. Na linha 3, expressa-se com voz autoral esclarecendo "eu acho legal essa pesquisa", avaliando de forma positiva, marcada pela escolha do léxico "legal", no sentido de interessante ou relevante. Das linhas 3-8, Tito faz uso da locução pronominal "a gente" para marcar a noção de plural, ou seja, a 
pesquisa como trabalho coletivo. Dessa forma, o aluno inclui-se no grupo com voz autoral e como sujeito/agente.

Tito parece reduzir a força avaliativa acerca da contribuição da turma na/para a pesquisa em - "a gente tá ajudando você um pouco" (linha 4), realizando uma avaliação de julgamento negativo de (in)capacidade, marcada pelo quantificador "pouco". A seguir, o aluno lança mão de um recurso conjuntivo - "mas a gente também tá se ajudando" (linha 5) para contrastar com o fato de estar colaborando pouco com a pesquisa. Tito revela o entendimento de que a pesquisa do praticante é um trabalho conjunto, que envolve a participação de todos.

Ao conversar sobre as atividades, "a gente tá relembrando o que a gente fez é: antes, a gente está pensando mais um pouco nisso" (linhas 5-8), Tito reconhece a importância da oportunidade de reflexão acerca do trabalho realizado na sala de aula. Percebo em seu discurso os princípios da Prática Exploratória: "trabalhar para a união de todos", "trabalhar para o desenvolvimento mútuo" (ALLWRIGHT; MILLER, 2001; ALLWRIGHT, 2003, p. 128-130). Nesse sentido, Tito parece compreender que, ao envolver os sete alunos na pesquisa, estou oportunizando um espaço para eles se entendam como praticantes e agentes de seu processo de construção de aprendizagem.

Tito refere-se à pesquisa como oportunidade de aprendizado (cf. learning opportunities) e, de forma mais ampla, como oportunidades de entendimentos. Tal postura é afirmada, nas linhas 22-25, quando diz, "pra mim todo mundo é uma parte importante mas não consigo reconhecer qual parte importante a pessoa é mas uma coisa é certa é importante". Tito parece compreender que o envolvimento do grupo é capaz de contribuir ativamente na pesquisa reflexiva e inclusiva. $\mathrm{O}$ reconhecimento de que está fazendo algo bom e importante é também compartilhado por Breno, no próximo excerto. Assim, Tito e Breno revelam, com suas avaliações, que o envolvimento dos alunos como atores participantes na construção da pesquisa pode contribuir para geração de múltiplos de entendimentos.

\section{Excerto 4 - Breno - "tenho um sentimento bom"}

\begin{tabular}{|l|l|l|l|}
\hline 01 & Mara & Breno, como você se sente participando desta \\
02 & & pesquisa? . . o o que cê pensa sobre ter as \\
03 & & suas ativida: des seus desenhos numa pesquisa \\
\hline
\end{tabular}




\begin{tabular}{|c|c|c|}
\hline 04 & & de adulto? \\
\hline 05 & Breno & seu $\mathrm{ach}=<$ eu gosto, eu me sinto bem \\
\hline 06 & Mara & aham como assim? cê explicar? \\
\hline $\begin{array}{l}07 \\
08\end{array}$ & Breno & $\begin{array}{l}\text { eu: tenho um sentimento bom, sinto que o que } \\
\text { eu fiz tá servindo pra alguma coisa }\end{array}$ \\
\hline $\begin{array}{l}09 \\
10\end{array}$ & Mara & $\begin{array}{l}\text { nossa que interessante e pra que você acha } \\
\text { que vai servir? }\end{array}$ \\
\hline $\begin{array}{l}11 \\
12\end{array}$ & Bre & $\begin{array}{l}\text { pra outros trabalhos eu vou usar esse pra } \\
\text { fazer outros trabalhos }\end{array}$ \\
\hline $\begin{array}{l}13 \\
14 \\
15\end{array}$ & Mara & $\begin{array}{l}\text { mmm como você explicaria a sua colaboração } \\
\text { na pesquisa a sua participação a sua } \\
\text { colaboração como você explicaria issô }\end{array}$ \\
\hline $\begin{array}{l}16 \\
17 \\
18\end{array}$ & Breno & $\begin{array}{l}\text { eu: explicaria: de: eu ajudar as outras } \\
\text { pessoas com os trabalhos que eu já fiz, as } \\
\text { outras pessoas que vão entrar aqui e verem }\end{array}$ \\
\hline 19 & Mara & aham vão ver o seu trabalho? \\
\hline $\begin{array}{l}20 \\
21\end{array}$ & Breno & $\begin{array}{l}\text { é: e pensar de outro jeito uma forma de } \\
\text { fazer }\end{array}$ \\
\hline 22 & Mara & nossa que interessante \\
\hline
\end{tabular}

Nesta interação, Breno responde às minhas indagações sobre sua participação na pesquisa em três etapas: primeiro, com um processo mental cognitivo para introduzir e elaborar sua resposta - " $>$ eu ach $=<"$; segundo, com um processo mental emotivo - "eu gosto"; terceiro, com outro processo mental emotivo eu me sinto bem (linha 5). Ao realizar uma avaliação positiva, o aluno revela a presença do afeto. Assim, Breno sente-se bem participando da pesquisa, o que é melhor elaborado por ele na linha 7, quando verbaliza "eu: tenho um sentimento bom". O aluno se expressa com voz autoral, realizando instâncias avaliativas de afeto explícito, as quais me levam a interpretar, por suas escolhas lexicais, que sua participação na pesquisa é algo positivo para ele.

Nas linhas 7 e 8, Breno revela, de forma explícita, uma postura altruísta e generosa ao expressar seus sentimentos sobre sua participação na pesquisa "sinto que o que eu fiz tá servindo pra alguma coisa". O aluno realiza uma avaliação com carga alta de afeto, indicando que, além de sentir-se bem, sentimento centrado nele, está contribuindo com os outros, ou seja, seu trabalho "tá servindo pra alguma coisa" (linha 8). Quando pergunto para que seu trabalho vai servir, Breno responde que "pra outros trabalhos, eu vou usar esse pra fazer outros trabalhos" (linhas 11 e 12). O aluno compartilha a noção de sustentabilidade da Prática Exploratória, de que o trabalho reflexivo propõe continuidade. 
Na sequência, Breno explica que com seu trabalho vai ajudar as pessoas, reforçando uma postura altruísta e uma essência de coletividade, nas linhas 16-18, "de eu ajudar as outras pessoas com os trabalhos que eu já fiz, as outras pessoas que vão entrar aqui e verem". O que me leva a interpretar que Breno expressa suas convicções de que a pesquisa é parte de um todo maior; de uma cadeia na qual um trabalho complementa o outro; e de que a pesquisa vai ser lida por outros. Nesse momento, identifico três princípios da Prática Exploratória, apresentados no capítulo 2: "Envolver todos neste trabalho"; "Trabalhar para a união de todos"; "Trabalhar para o desenvolvimento mútuo" (ALLWRIGHT; MILLER, 2001; ALLWRIGHT, 2003; MILLER et al., 2008; MILLER; CUNHA, 2017; HANKS, 2017). Breno mostra bastante maturidade para sua idade ao reconhecer a importância de seu envolvimento com a pesquisa e ao apresentar a noção de que uma pesquisa pode atingir outras pessoas e pode contribuir para que outras pessoas possam "pensar de outro jeito uma forma de fazer" (linhas 20-21). Breno parece compreender que um trabalho de pesquisa contribui de alguma forma para a melhoria da sociedade, deixa um legado, provoca reflexões e leva a novos entendimentos. Da forma como entendo, para Breno, uma pesquisa é relevante quando leva pessoas a pensarem de uma outra maneira e a entenderem outras formas de agir, fazer e de trabalhar.

Breno, assim como Tito no excerto anterior, revela discursivamente que se entende como sujeito ativo, participando, cooperando, refletindo e gerando oportunidades de crescimento para todos. Essa noção também é compartilhada por Daniel, no próximo excerto.

\section{Excerto 5 - Daniel - "ajudando seu trabalho a ser maior e melhor"}

\begin{tabular}{|c|c|c|}
\hline $\begin{array}{l}01 \\
02\end{array}$ & Mara & $\begin{array}{l}\text { Daniel como você se sente participando dessa } \\
\text { pesquisa? }\end{array}$ \\
\hline $\begin{array}{l}03 \\
04 \\
0 \\
0 \\
0\end{array}$ & Daniel & $\begin{array}{l}\text {... eu me sinto um pouco: <vergonhoso> ... } \\
\text { falando que: sobre o que é uma pesquisa é:: } \\
\text {... eu também me sinto feliz porque tô } \\
\text { participando da pesquisa de um adulto }\end{array}$ \\
\hline $\begin{array}{l}07 \\
08 \\
09\end{array}$ & Mara & $\begin{array}{l}\text { O que você pensa sobre ter as suas } \\
\text { atividades os seus desenhos numa pesquisa de } \\
\text { adulto? }\end{array}$ \\
\hline $\begin{array}{l}10 \\
11\end{array}$ & Dar & $\begin{array}{l}\text { mmm eu me sinto muito bem sabendo que: } \\
\text { minhas atividades vão pra: universidade }\end{array}$ \\
\hline $\begin{array}{l}12 \\
13\end{array}$ & $\operatorname{Mar}$ & $\begin{array}{l}\text { qual cê acha que é a importância da sua } \\
\text { participação da sua colaboração? }\end{array}$ \\
\hline 14 & el & participação \\
\hline
\end{tabular}


Neste trecho, Daniel responde à primeira pergunta afirmando sentir-se "<vergonhoso>", na linha 3 e "feliz", na linha 5. Na primeira escolha, provavelmente, o aluno quis dizer 'envergonhado' no sentido de tímido ou acanhado por saber que a conversa está sendo gravada em áudio, algo nada comum durante as aulas. Na segunda, diz sentir-se "feliz" (linha 5), atributo que traz explicitamente a carga semântica de afeto realizada na categoria felicidade/infelicidade. Suas escolhas léxico-gramaticais me levam a entender que, apesar de sentir vergonha em alguns momentos, está feliz por participar de uma "pesquisa de um adulto" (linha 6) e por saber que suas "atividades vão pra universidade" (linha 11). Na minha análise, interpreto que Daniel tem noção da importância de seu papel como alunocolaborador nas várias etapas da pesquisa.

Na linha 14, Daniel avalia sua participação na pesquisa como "boa", a qual interpreto a escolha do atributo de graduação média como uma apreciação no campo da capacidade em reação-qualidade. Chamo especial atenção para o trecho seguinte, nas linhas 14 e 15, "ajudando é: : seu trabalho a ser maior e: melhor". Daniel aponta para a importância da sua participação e colaboração na pesquisa e apresenta a noção de que ao dar sua contribuição, a pesquisa se torna "maior e: melhor" (linha 15), no sentido de tamanho e de qualidade. Seu posicionamento me leva a considerar que Daniel apresenta crenças sobre o que é uma pesquisa acadêmica e que explicita através de seu discurso o quanto sua participação contribuirá positivamente para a dissertação como trabalho final.

\section{Excerto 6 - Gael - "numa pesquisa séria da teacher"}

\begin{tabular}{|c|c|c|}
\hline $\begin{array}{l}01 \\
02\end{array}$ & Mara & $\begin{array}{l}\text { Gael é: como você se sente participando } \\
\text { dessa pesquisa? }\end{array}$ \\
\hline $\begin{array}{l}03 \\
04\end{array}$ & Gael & $\begin{array}{l}\text { feliz é: } \text { bem legal, eu me sinto: : ajudando } \\
\text { a teacher fazer a pesquisa dela da PUC }\end{array}$ \\
\hline $\begin{array}{l}05 \\
06 \\
07\end{array}$ & Mara & $\begin{array}{l}\text { O que você } \\
\text { atividades, os } \\
\text { de adulto? }\end{array}$ \\
\hline 08 & $\mathrm{Ga}$ & me sinto importante ((risos)) \\
\hline 09 & Mara & sério $\uparrow$ que legal \\
\hline 10 & Gael & $(($ tosse $))$ \\
\hline
\end{tabular}




\begin{tabular}{|c|c|c|}
\hline $\begin{array}{l}11 \\
12 \\
13 \\
14\end{array}$ & & $\begin{array}{l}\text { responsabilidade ter as atividades numa } \\
\text { pesquisa séria da teacher que se eu tipo eu } \\
\text { fizer uma bobagem pode ser tipo: ruim na } \\
\text { hora de botar a minha atividade }\end{array}$ \\
\hline $\begin{array}{l}15 \\
16\end{array}$ & Mara & $\begin{array}{l}\text { qual você acha que é a importância da sua } \\
\text { colaboração, da sua participação? }\end{array}$ \\
\hline 17 & Gael & uma importância? \\
\hline 18 & Mara & é \\
\hline 19 & Gael & $\mathrm{mmm} \quad \ldots$ \\
\hline 20 & Mara & você se sente colaborando? \\
\hline 21 & Gael & me sinto eu ach- \\
\hline $\begin{array}{l}22 \\
23\end{array}$ & Mara & $\begin{array}{l}\text { [então qual a importância da } \\
\text { sua colaboração?] }\end{array}$ \\
\hline $\begin{array}{l}24 \\
25 \\
26 \\
27 \\
28 \\
29 \\
30\end{array}$ & Gael & $\begin{array}{l}\text { que ajuda é: a ter: mais coisas pra bota:r } \\
\text { na atividade ((tosse)) que você não precisa: } \\
\text { pensar >que tipo< é: : ajuda a teacher, a } \\
\text { pesquisa é bem grande então >ao invés de } \\
\text { ficar< pensando em tudo que ela tem que } \\
\text { fazer já ajuda, gasta um grande espaço da } \\
\text { pesquisa botando atividades da nossa turma }\end{array}$ \\
\hline 31 & Mara & sah entendi< \\
\hline
\end{tabular}

Neste trecho, Gael responde à minha pergunta realizando uma avaliação positiva a respeito de sua participação na pesquisa, apontando que se sente "feliz" (linha 3) e "importante" (linha 8), o que entendo como satisfeito e prestigiado, respectivamente. $\mathrm{Na}$ linha 8 , Gael lança mão do recurso paralinguístico do riso ao dizer "me sinto importante", o que, para mim, revela como um certo orgulho por estar participando da pesquisa.

Retomando a linha 3, o aluno expressa-se com voz autoral "eu me sinto:: ajudando a teacher fazer a pesquisa dela da PUC". Acho importante apontar que o aluno escolhe fazer uso da terceira pessoa ao invés de dizer 'ajudando você a fazer sua pesquisa na PUC'. O que é repetido na linha 12, "numa pesquisa séria da teacher", depois, na linha 26, "ajuda a teacher" e nas linhas 28-29, "pensando em tudo que ela tem que fazer". Somente na linha 25, Gael faz uso da segunda pessoa do singular "você não precisa: pensar", o que, logo em seguida, troca para terceira pessoa novamente "pensando em tudo que ela tem que fazer" (linhas 28-29). Em uma interação face a face, levando em consideração o grau de proximidade que temos na relação professora-aluno, é curioso observar como Gael escolhe construir seu discurso dessa forma. Interpreto sua escolha como uma maneira que ele encontrou de se posicionar em um tom mais formal, sabendo que estava sendo 
gravado e de mostrar distanciamento, indicando ser eu a pesquisadora e ele o pesquisado. Contudo, apesar desse posicionamento, Gael se constrói como participante ativo da pesquisa.

Nas linhas 10-12, Gael relata que "é uma grande responsabilidade ter as atividades numa pesquisa séria da teacher". Destaco a escolha do termo "responsabilidade" (linha 11) que é intensificado pelo atributo "grande" (linha 10), o que corrobora a noção de compromisso e agentividade em relação à pesquisa. As escolhas realizadas sugerem que o aluno tem noção da importância de sua participação na pesquisa. Além disso, o uso do léxico "séria" (linha 12) para caracterizar a pesquisa, acrescido do recurso paralinguístico de ênfase indica o valor que Gael atribui à pesquisa. Gael aponta, assim, com seu discurso, a noção do que vem a ser uma pesquisa acadêmica. Em seguida, o aluno cria uma situação hipotética para exemplificar a seriedade do trabalho: "se tipo eu fizer uma bobagem pode ser tipo: ruim na hora de botar a minha atividade" (linhas 12-14). Gael se refere ao seu envolvimento e comprometimento com as atividades e, ao mesmo tempo, à sua preocupação de expor seus trabalhos, sabendo que outras pessoas irão ler. Assim, o léxico "bobagem" (linha 13) poderia estar relacionado à algo sem sentido, o que contrastaria com uma pesquisa, por ele, considerada "séria" (linha 12).

Gael explica sua colaboração na pesquisa esclarecendo que as atividades da turma contribuem para "ter: mais coisas pra bota: $r$ " (linha 24) no texto da dissertação, pois como a pesquisa "é bem grande" (linhas 26-27), incluir as atividades dos alunos "gasta um grande espaço da pesquisa" (linhas 29-30). Assim como Daniel no excerto anterior, Gael faz referência ao tamanho de uma pesquisa acadêmica comparada, talvez, às pesquisas que realiza na escola como aluno do $4^{\circ}$ ano. Da maneira como interpreto, o aluno quis dizer que incluir as atividades da turma serve para ocupar espaço, dar volume, aumentar o número de páginas da pesquisa. Para mim, esta noção parece indicar certa ambiguidade. Ao mesmo tempo que, para ele, a pesquisa é "séria" (linha 12) e "grande" (linhas 10 e 27), a participação dos alunos contribuindo com suas atividades parece ser reduzida a ocupar "um grande espaço da pesquisa" (linhas 29-30). Contudo, percebo também sua preocupação em colaborar e 
contribuir, nas linhas 27-29 ">ao invés de ficar< pensando em tudo que ela tem que fazer já ajuda", ou seja, eu, professora-pesquisadora não preciso pensar/fazer tudo sozinha porque estamos trabalhando juntos, conforme os princípios da Prática Exploratória (ALLWRIGHT; MILLER, 2001; ALLWRIGHT, 2003; MILLER et al., 2008; MILLER; CUNHA, 2017; HANKS, 2017).

Neste fragmento, Gael parece mostrar sua compreensão de que a pesquisa do praticante é um trabalho de construção conjunta, que gera oportunidades de aprendizagens e de entendimentos para todos os aprendizes, professora e alunos. Essa noção de trabalho em equipe é compartilhada por Bruna, como podemos ver no excerto seguinte.

\section{Excerto 7 - Bruna - "nunca imaginei"}

\begin{tabular}{|c|c|c|}
\hline $\begin{array}{l}01 \\
02\end{array}$ & Mara & $\begin{array}{l}\text { então Bruna como você se sente participando } \\
\text { da pesquisa? }\end{array}$ \\
\hline $\begin{array}{l}03 \\
04 \\
05 \\
06\end{array}$ & Bru & $\begin{array}{l}\text { eu: me sinto tipo: é: só apenas com: dez } \\
\text { anos participando de uma pesquisa tão grande } \\
\text { assim eu tô: im-pressio-nada eu tô né } \uparrow \text { um } \\
\text { pouco feliz ao mesmo tempo }\end{array}$ \\
\hline 07 & Mara & ${ }^{\circ}$ humhum ${ }^{\circ}$ \\
\hline $\begin{array}{l}08 \\
09 \\
10\end{array}$ & Bruna & $\begin{array}{l}\text { é: mas: : eu nunca imaginei que com dez anos } \\
\text { eu taria participando de uma pesquisa tão } \\
\text { grande assim }\end{array}$ \\
\hline $\begin{array}{l}11 \\
12 \\
13\end{array}$ & Mara & $\begin{array}{l}\text { <nossa> é: o que que você pensa sobre ter as } \\
\text { suas atividades seus desenhos numa pesquisa } \\
\text { de adulto? }\end{array}$ \\
\hline 14 & Bruna & é: : >se eu fosse uma adulta?< \\
\hline $\begin{array}{l}15 \\
16 \\
17 \\
18\end{array}$ & Mara & $\begin{array}{l}\text { acha, o que você pensa sobre isso que você } \\
\text { vai ter seus desenhos e assim as coisas que } \\
\text { você escreveu numa pesquisa de adulto? }\end{array}$ \\
\hline $\begin{array}{l}19 \\
20 \\
21 \\
22 \\
23 \\
24 \\
25\end{array}$ & Br & $\begin{array}{l}\text { é né } \uparrow \text { eu acho que isso é bem legal né } \uparrow \\
\text { porque os-os desenhos cada um desenha do seu } \\
\text { jeito >assim né< eu: gosto de desenhar } \\
\text { certas coisas, outras é um de-sa-fio >vamos } \\
\text { dizer pra mim< então eu acho legal né } \uparrow \text { fazer } \\
\text { desafios e o que eu escrevi eu acho que vai } \\
\text { ser tipo a pessoa vê: : escreveu sabe assim }\end{array}$ \\
\hline 26 & $\mathrm{Mc}$ & aham \\
\hline $\begin{array}{l}27 \\
28 \\
29 \\
30 \\
31 \\
32 \\
34\end{array}$ & Bruna & $\begin{array}{l}\text { ver o que escrevi eu ficaria impressionada } \\
\text { né } \uparrow \text { ainda mais é bom porque às vezes eu } \\
\text { tenho vergonha de algumas coisas né } \uparrow \text { e como } \\
\text { eu gosto muito do teatro sessas coisas< né } \\
\text { pra eu enfrentar esse desafio pra mim que é } \\
\text { ser uma atriz né } \uparrow \text { eu tenho que perder isso }\end{array}$ \\
\hline
\end{tabular}




\begin{tabular}{|c|c|c|}
\hline & & então eu acho que é uma coisa boa pra mim \\
\hline $\begin{array}{l}35 \\
36\end{array}$ & Mara & $\begin{array}{l}\text { que bom é: : você se sente colaborando na } \\
\text { pesquisa? }\end{array}$ \\
\hline 37 & Bruna & sim \\
\hline 38 & Mara & como que você se sente colaborando? \\
\hline 39 & Bruna & ah: : tipo ah: : >o que é colaborar mesmo?< \\
\hline $\begin{array}{l}40 \\
41\end{array}$ & Mara & fazendo coisas para \\
\hline $\begin{array}{l}42 \\
43 \\
44 \\
45 \\
46 \\
47 \\
48 \\
49\end{array}$ & Bruna & $\begin{array}{l}\text { eu me sinto feliz porque é bom a gente fazer } \\
\text { trabalho de equipe né assim } \uparrow \text { porque sempre } \\
\text { a gente ficar muito sozinho assim não é } \\
\text { legal, eu não gosto de ver todo mundo } \\
\text { sozinho, eu gosto sempre de ter amigos } \\
\text { inclusive eu vi dois amigos ((risos)) meus } \\
\text { da escola antiga eu vi agorinha mesmo pra } \\
\text { fazer prova pra entrar na escola }\end{array}$ \\
\hline 50 & Mara & é: mesmo^ \\
\hline
\end{tabular}

Assim como Tito, Breno, Daniel e Gael, Bruna parece se entender como agente da pesquisa, como praticante. Neste excerto, destaco a escolha do léxico 'impressionada', empregado duas vezes pela aluna. Na linha 5, "eu tô: impressio-nada", Bruna lança mão do recurso paralinguístico de ênfase e silabação da palavra. Na linha 27, "ver o que escrevi eu ficaria impressionada", faz uso do recurso paralinguístico de ênfase. É possível notar que uma avaliação de afeto permeia seu discurso a partir da seleção desse item lexical, revelando uma expressão de espanto, de impacto ou de comoção a respeito de sua participação na pesquisa.

Seu sentimento em relação à participação na pesquisa fica evidente nas linhas 3-5 "só apenas com: dez anos participando de uma pesquisa tão grande assim" e nas linhas 8-10 "eu nunca imaginei que com dez anos eu taria participando de uma pesquisa tão grande assim". Bruna parece chamar a atenção para um possível contraste entre sua idade e o tamanho/importância da pesquisa. Nos dois fragmentos, a escolha de "tão grande assim" (linhas 5-6 e linhas 9-10) parece revelar seu entendimento de que uma dissertação é diferente do que ela conhece como pesquisa escolar.

Retomando à linha 8, "eu nunca imaginei", Bruna parece realizar uma avaliação implícita no campo semântico do afeto, ou seja, ela nem sequer pensou que, com tão pouca idade, participaria de uma pesquisa de universidade. 
Quando indaguei Bruna como se sentia sabendo que seus desenhos e textos fariam parte da pesquisa, ela responde "eu acho que isso é bem legal" (linha 19), realizando uma avaliação positiva marcada pelo léxico 'legal'. Mais adiante, nas linhas 21-22, Bruna realiza uma avaliação explícita no campo do afeto em "eu: gosto de desenhar certas coisas, outras é um de-sa-fio >vamos dizer pra mim<". Destaco que a aluna faz uso dos recursos paralinguísticos de ênfase e de silabação da palavra para expressar uma avaliação de alta graduação, ou seja, desenhar algo, por ela não especificado, parece apresentar-se com "um de-sa-fio" (linha 22). Bruna acrescenta que "então eu acho legal né $\uparrow$ fazer desafios" (linhas 23-24), o que corrobora com a ideia de que a dificuldade encontrada para desenhar "certas coisas" pode ser superada por ela.

$\mathrm{O}$ fato de saber que outras pessoas irão ler seus textos parece causar um embaraço, diferentemente dos desenhos, pois conforme a aluna justifica, "cada um desenha do seu jeito" (linhas 20-21). Com relação a inclusão de textos, Bruna revela que "ver o que escrevi eu ficaria impressionada né $\uparrow^{\prime \prime}$ (linhas 27-28). Bruna lança mão de uma situação hipotética para expressar: se eu visse meus textos, eu ficaria impressionada. Porém, ao mesmo tempo, afirma que "às vezes eu tenho vergonha de algumas coisas" (linhas 28-29). Assumindo uma postura reflexiva, a aluna cita o exemplo do teatro para, então, realizar uma avaliação positiva "eu acho que é uma coisa boa pra mim" (linha 34). Mesmo tendo "vergonha" (linha 29), Bruna parece entender que tem que "enfrentar esse desafio" (linha 31), o que, na minha opinião, é um sinal de bastante maturidade, se considerarmos que tem apenas 10 anos de idade.

Ao refletir sobre sua participação na pesquisa, Bruna realiza uma avaliação positiva no campo do afeto, nas linhas 42-43, "eu me sinto feliz porque é bom a gente fazer trabalho de equipe". Bruna parece entender que a pesquisa é um trabalho coletivo, o qual envolve seus colegas e eu, ou seja, que nós priorizamos a "união de todos" e o "desenvolvimento mútuo" (ALLWRIGHT; HANKS, 2009). Bruna parece mostrar a compreensão do que significa trabalhar e refletir coletivamente. Nas linhas 45-46, ao fazer uma avaliação no campo semântico do afeto em "eu não gosto de ver todo 
mundo sozinho, eu gosto sempre de ter amigos", a aluna reforça os princípios da Prática Exploratória e o conceito de integração, apresentado no capítulo 2.

Bruna, assim como seus colegas, mostra bastante maturidade reflexiva e um senso de responsabilidade e compromisso acerca de seu envolvimento com a pesquisa.

\section{5.}

\section{Meus entendimentos}

Já mencionado nos capítulos anteriores, a pesquisa do praticante gera oportunidades de aprendizagens e de crescimento para todos os participantes sujeitos ativos - que buscam entender suas questões. A possibilidade de refletir acerca da participação na pesquisa revelou a maturidade de cada aluno como praticante exploratório. Apesar da pouca idade, os sete alunos mostraram seus entendimentos em relação a uma pesquisa acadêmica e compartilharam suas experiências subjetivas, suas crenças e seus saberes.

Quase seis meses depois das conversas exploratórias gravadas em áudio, perguntei para cada aluno - $\mathrm{O}$ que você sentiu no dia que gravamos nossas conversas? Como foi a experiência para você? - mmmm As respostas foram:

\section{Giovana}

"Ah, foi emocionante! Nunca tinha feito algo assim tão importante".

\section{Theo}

"Não lembro bem; eu não sabia o que falar; fiquei envergonhado".

\section{Tito}

"Me senti famoso porque as pessoas entrevistam pessoas famosas".

\section{Breno}

"Primeiro não entendi muito, fiquei meio nervoso, eu sozinho. Depois entendi melhor, mas achei legal. Eu nunca fiz isso antes. Eu só entrevistei pessoas, mas nunca tinha sido entrevistado".

\section{Daniel}

"Achei legal de você chamar as crianças, de você perguntar dos trabalhos; fiquei bem envergonhado". 


\section{Gael}

"Senti vergonha, óbvio! Me senti responsável porque era uma coisa importante pra você”.

\section{Bruna}

"Fiquei meio nervosa porque tinha o gravador; sou tímida; falei o que tinha na cabeça".

Primeiro, destaco que é possível captar discursivamente a individualidade da experiência vivida por cada um dos alunos participantes. Na pesquisa do praticante, o ensino, a aprendizagem e a pesquisa acontecem de forma integrada na sala de aula. Assim, entendo que as Atividades Pedagógicas com Potencial Exploratório, por serem atividades da rotina escolar, não despertaram estranhamento nos alunos. Já as conversas exploratórias gravadas no celular foram entendidas como algo diferente, não comum no dia a dia do Programa Bilíngue. Talvez, por este motivo, as conversas gravadas tenham causado impacto e também proporcionado uma visão mais ampliada da participação de cada um na pesquisa.

Segundo, acho que esse momento, meses depois das primeiras conversas gravadas, ilustra que a pesquisa do praticante é um processo contínuo, no qual uma questão pode levar a outras. Sendo uma professora-pesquisadora-praticante, entendo minha sala de aula como um ambiente reflexivo e inclusivo, como um espaço social de compartilhamentos e de confiança mútua, como um lugar de construção e de trabalho conjunto e contínuo. 


\section{8 \\ Considerações finais}

Começo com uma tentativa de responder à indagação feita no início da dissertação: então, quem somos nós nesse espaço-lugar e tempo situados, que se caracterizam discursivamente nesta dissertação de mestrado?

Certamente, não sou a mesma pessoa que chegou na escola para participar de uma reunião com a diretora administrativa e a coordenadora geral, a convite de uma colega. Hoje, vejo a escola onde trabalho há 17 anos como espaço de construções de saberes que surgem de três pilares - conhecimento, cultura e valores - os quais embasam sua filosofia. A escola tem suas ideologias situadas em um campo sócio-histórico-cultural, com regras, regulamentos e algumas práticas que podem mudar com o passar do tempo, enquanto outros permanecem e são compartilhados pelo grupo que ali trabalha. Assim, a escola apresenta um perfil único com especificidades locais; um caráter político-social-cultural quase sempre perceptível na escolha das linhas pedagógicas; uma atmosfera que vibra em cores, cheiros e sons. As características da escola podem transparecer na arquitetura dos prédios, nas cores das paredes, nos jardins, no uso do uniforme, e na postura ética e crítica dos que ali habitam. As trocas e interações que acontecem lá dentro se interseccionam com o que acontece além dos muros da instituição. Eu ainda estou me formando nesta escola.

Também, certamente, não sou a mesma pessoa que cursou as primeiras disciplinas do Mestrado, como aluna extraordinária, em 2017. Assim como a escola, cada universidade tem seu perfil, sua filosofia, sua individualidade e suas peculiaridades. A PUC-Rio destaca-se por ser uma instituição de excelência acadêmica e de tradição, alicerçada em valores humanos e na ética. Integrar esta comunidade requer responsabilidade individual e compromisso social. Entendo que minha passagem pela universidade provocou, em mim, muitas reflexões e aprendizados. Eu estou me formando nesta universidade.

Tanto quanto eu, professora-pesquisadora-praticante, os sete alunos participantes, hoje, não são os mesmos que iniciaram comigo essa aventura pela estrada acadêmica. Já cresceram e amadureceram, continuam questionando, investigando e buscando entendimentos sobre o mundo que os cerca, movidos pela curiosidade característica da infância. Enquanto estávamos aprendendo e 
ensinando, pesquisamos juntos a vida na sala de aula do Programa Bilíngue, como praticantes exploratórios. Essa busca deu origem à dissertação.

Após a tentativa de responder à indagação inicial, reflito sobre meus objetivos nesta pesquisa:

\section{1) buscar maiores entendimentos acerca do trabalho do professor de inglês} nos primeiros anos de escolarização, da escola como lugar de afetos e da participação na pesquisa

Essa busca aconteceu de forma colaborativa com os alunos, através das Atividades Pedagógicas com Potencial Exploratório, nas conversas gravadas e transcritas e durante as aulas. Analisando o conjunto de dados pude observar que os alunos avaliam o professor de inglês nos primeiros anos de escolarização no âmbito do julgamento do comportamento, principalmente na subcategoria de capacidade. O quão capaz é o professor de falar inglês, de brincar, de ensinar, de pensar dentro e fora da caixa, de conversar, de pesquisar? Suas avaliações me levam a entender que, no momento, eles privilegiam o conhecimento que o professor tem da língua, mas valorizam o professor que acolhe, que cuida e que gosta deles. Estas ocorrências no discurso dos alunos me levam a entender que o afeto permeia as relações construídas na escola.

Em relação ao lugar-escola, os alunos realizaram avaliações no âmbito do afeto explicitado nos sentimentos de carinho por eles apontados nas atividades e conversas. Um ponto de destaque foi a aproximação com a natureza e a oportunidade de vivenciar experiências sensoriais como tocar na terra, na areia, nas árvores, como apreciar cores, plantas, como sentir o lugar-escola que habitam.

As reflexões acerca da participação mostram que os alunos consideram a responsabilidade, o compromisso e o envolvimento de cada um como parte fundamental para a construção desta pesquisa.

\section{2) observar/monitorar a vida e as interações na sala de aula}

Para mim, observar o que acontece na sala de aula relaciona-se ao conceito de monitoring (ALLWRIGHT, 1996). No entanto, as observações feitas nem sempre são registradas de forma escrita no caderno/diário que mantenho aberto todas as aulas. Muitas delas são mentais (cf. mental notes). O registro desta sequência de encontros que durou, pelo menos, um ano letivo, isto é, 200 dias, 
não está nem poderia estar completo; a dissertação foi um recorte do que vivenciamos. Neste cenário de encontros, brincamos, aprendemos, desenhamos, escrevemos, pintamos, lemos, contamos histórias, ouvimos histórias, conversamos, fizemos atividades, construímos maquetes, estudamos, memorizamos textos, apresentamos peça de teatro ... e sonhamos juntos. Essa multidiversidade de vivências caracteriza a convivência no espaço físico da sala de aula e pode ser de alguma forma observável. Também, neste espaço geográfico ocorrem uma multiplicidade de experiências que não são visíveis e nem tampouco são tangíveis. O que fazemos na sala de aula não é só cumprir o currículo, o planejamento mensal, o semanal e o diário. A aula é um encontro de pessoas e o que acontece dentro de cada um não tem como ser medido ou avaliado. Assim, observei ao mesmo tempo que vivenciei a vida em nossa sala de aula.

\section{3) refletir sobre questões relacionadas ao grupo}

Ao longo do ano, dividimos a sala de aula, compartilhamos saberes, ideias e afetos, construímos conhecimentos, e mais importante, buscamos entendimentos para nossas questões. Como professora praticante, trabalho para entender a vida na sala de aula e acredito que minha pesquisa está situada em um contexto sóciohistórico-cultural, localmente produzida pelos alunos e por mim. Portanto, durante o processo de construção da dissertação, ouvi os alunos, observei suas interações, prestei atenção às suas críticas e queixas, favoreci espaço para o diálogo, criei oportunidades para que se envolvessem e acompanhassem as etapas da pesquisa (PINTER, 2014), sempre atenta ao "agir ético" (MILLER, 2010) que envolve trabalhar e pesquisar com crianças. As reflexões exploratórias fazem parte da rotina da vida na sala de aula. Refletimos sobre um comportamento não adequado, sobre algo que falamos e que de alguma forma pode não ter agradado o outro, sobre as atividades, sobre as viagens e os fins de semana, e muito mais.

\section{4) integrar pesquisa e práticas pedagógicas de ensino e aprendizagem.}

A experiência de incluir e envolver os sete alunos na pesquisa foi um desafio em alguns momentos pela seriedade e pelas formalidades dos moldes de um texto acadêmico. O que desejei desde o início, como mestranda, foi trazer a escola para a universidade e levar a universidade para dentro da escola onde trabalho, por acreditar que podemos compartilhar saberes, ideias e experiências. 
Para mim, trazer a escola para universidade significa trazer criatividade e espontaneidade e, mais importante, trazer a voz das crianças para a academia. Em todas as etapas da pesquisa e durante as aulas do Mestrado, acredito que minha intenção foi unir ensino, aprendizagem e pesquisa. Para mim, Giovana, Theo, Tito, Breno, Daniel, Gael e Bruna são coautores da dissertação. Sem eles, teria sido tudo diferente.

Ao refletir sobre os objetivos, percebo que não cheguei a uma conclusão, que não tenho respostas, mas sim cheguei a alguns entendimentos sobre as crenças e as emoções que permearam nossa vida, nosso convívio, nossos pensamentos, enquanto aprendizes em nossa sala de aula, habitando o lugar-escola.

Minha motivação inicial - o desenvolvimento mútuo, individual e coletivo dos participantes e o foco no trabalho colaborativo em relação a questões do cotidiano pedagógico e interacional do Programa Bilíngue da escola - continua presente em mim.

No percurso delineado durante o processo da pesquisa na escola e na universidade, destaco o fio que conectou todas as relações, entendido, pelos autores citados, de várias formas: Amorosidade para Paulo Freire, Amor para Humberto Maturana, afetividade e cuidado essencial para Leonardo Boff, Afeto para Adriana Nóbrega, e Qualidade de vida para Inés Miller. Mesmo com nomes diferentes, é possível afirmar que o afeto/amor/carinho/cuidado permeou as relações humanas ora como professora, ora como aluna. "Tudo é afeto" (NÓBREGA - comunicação pessoal).

"É no coração que residem os valores, o mundo das excelências, dos afetos e dos grandes sonhos que orientam a vida" (BOFF, 2010, p.171). Então,

Qual é a experiência-base da vida humana? É o sentimento, o afeto e o cuidado. [...] A existência jamais é pura existência; é uma coexistência, sentida e afetada pela ocupação e pela preocupação, pelo cuidado e pela responsabilidade no mundo com os outros, pela alegria ou pela tristeza, pela esperança ou pela angústia. (ibidem, p. 172)

Na construção da dissertação, entendida por mim como uma experiência de vida, senti a responsabilidade de estar ligada a um programa de pesquisa, a preocupação com prazos e datas de entrega, a angústia de achar que o trabalho poderia ser melhor, a tristeza de saber que estou chegando ao fim de um processo que culmina com a entrega da dissertação. Senti, ao longo destes três anos, a 
alegria de pertencer ao PPGEL e de conviver com os professores e colegas. Senti vontade de começar ou continuar ou não parar a pesquisa. Senti a esperança de que essa pesquisa pode contribuir de alguma forma para novos entendimentos. Senti o afeto e o carinho das minhas orientadoras. Senti o apoio dos meus colegas. Senti o encanto de transitar por um campus tão bonito e bem cuidado, que assim como a escola, tem natureza, cor, cheiro, beleza. Senti a delícia que foi e é conviver e aprender com Giovana, Theo, Tito, Breno, Daniel, Gael e Bruna.

Resolvi, então, chamar este capítulo de considerações finais, mas entendo que não cheguei a uma conclusão, apenas preciso finalizar a dissertação. Uma pesquisa acadêmica tem um fim, diferentemente da pesquisa do praticante, na qual uma questão leva a outras em um fazer e refletir contínuos e constantes. Assim, preparo-me para o fechamento da pesquisa e faço minhas as palavras de Giovana, "eu amei fazer esse trabalho". 


\section{9 \\ Referências bibliográficas}

ABREU, Adriana R.; NÓBREGA, Adriana N. A. Avaliação e argumentação: uma análise da produção textual no ensino médio. Linguagem em (Dis)curso, v. 15, n. 2, p. 285-302. Unisul, Tubarão, SC, maio/ago, 2015.

ALLWRIGHT, Dick. Exploratory Teaching, Professional Development, and the role of a teacher association. Havana, Cuba, 1991.

Disponível em

http://www.letras.puc-

rio.br/unidades\&nucleos/epcentre/readings/cuba\%2091\%20paper.htm

Acessado em julho de 2019.

ALLWRIGHT, Dick. Monitoring. Manuscrito não publicado, Lancaster University, UK, 1996.

ALLWRIGHT, Dick. Classroom Language Learning: Public Behaviour; Private Learning. Plenary Speaker. The Eighth Annual KOTESOL International Conference, Korea, Sep.30-Oct.1, 2000.

ALLWRIGHT, Dick. Three major processes of teacher development and the appropriate design criteria for developing and using them. In: JOHNSTON, B. IRUJO, S. (orgs). Research and Practice: Voices from the Field. p. 115133. Center for Advanced Research on Language Acquisition University of Minnesota, Minneapolis, 2001.

ALLWRIGHT, Dick. Exploratory Practice: rethinking practitioner research in language teaching. Language Teaching Research, v. 7, .n 2, p. 113$141,2003$.

ALLWRIGHT, Dick. Developing principles for practitioner research: the case of Exploratory practice. The modern Language Journal, Lancaster, v. 89, n. 3. p. 353-366, 2005.

ALLWRIGHT, Dick. Six Promising Directions for Applied Linguistics. In: S. GIEVE, S.; MILLER, I. (Eds.). Understanding the Language Classroom. p. 11-17. $1^{\text {st }}$ ed. Basingtoke: Palgrave Macmillan, 2006.

ALLWRIGHT, Dick. Trust as a by-product of involvement in Exploratory Practice, and its relationship to the demand for enhanced performance outcomes. Rio de Janeiro, 2009a. (Manuscrito)

ALLWRIGHT, Dick; BAILEY, Kathleen M. Focus on the Language Classroom: an introduction for language teachers. Cambridge: Cambridge University Press, 1991. 
ALLWRIGHT, Dick; HANKS, Judith. The developing language learner: an introduction to Exploratory Practice. Hampshire: Palgrave Macmillan, 2009.

ALLWRIGHT, Dick; MILLER, Ines K., Bringing work 'to life': Exploratory Practice for the language classroom. Hong Kong, 2001.

Disponível em

http://www.letras.puc-

rio.br/unidades\&nucleos/epcentre/readings/bringing work life.htm

Acessado em julho de 2019.

ANDRÉ, Marli E. D. A. Etnografia da prática escolar. $18^{\circ}$ ed. (Série Prática Pedagógica), São Paulo: Papirus, 2012.

ARAGÃO, Rodrigo C. Linguajar e emocionar os tempos de crise na formação de professores de línguas. Cap. 11. In: SILVA, Walkyri M.; SILVA, Wagner R.; CAMPOS, Diego M. (Orgs.) Desafios da Formação de Professores na Linguística Aplicada. Campinas, SP: Pontes Editores, 2019.

BAKER, Colin. Foundations of Bilingual Education and Bilingualism. $4^{\text {th }}$ ed. Clevedon: Multilingual Matters, 2010.

BARCELOS, Ana M. F. Metodologia de pesquisa das crenças sobre aprendizagem de línguas: Estado da arte. Revista Brasileira de Linguística Aplicada, v. 1, n.1, pp. 71-92, 2001.

BARCELOS, Ana M. F. Crenças sobre aprendizagem de línguas, Linguística Aplicada e ensino de línguas. Linguagem \& Ensino, v. 7, n. 1, p. 123-156, Pelotas: Educat, 2004.

BARCELOS, Ana M. F. Cognição de professores e alunos: tendências recentes na pesquisa de crenças sobre ensino e aprendizagem de línguas. In: BARCELOS, A. M. F.; VIEIRA-ABRAHÃO, M. H. (Org.). Crenças e ensino de línguas: foco no professor, no aluno e na formação de professores. p. 15-42. Campinas: Pontes, 2006.

BARCELOS, Ana M. F. Reflexões acerca da mudança de crenças sobre ensino e aprendizagem de línguas. Revista Brasileira de Linguística Aplicada. v. 7, n. 2 p. 109-138, 2007.

BARCELOS, Ana M. F. Desvendando a relação entre crenças sobre ensino e aprendizagem de línguas, emoções e identidades. In: GERHARDT, A. F. L.; AMORIM. M. A.; CARVALHO, A. M. (Orgs). Cap. 5. p. 153-186. Linguística Aplicada e Ensino: Língua e Literatura. Campinas: Pontes, 2013.

BARCELOS, Ana M. F.; SILVA, Denize D. Crenças e emoções de professores de inglês em serviço. Revista Contexturas, no. 24, p. 6-19, 2015. 
BARCELOS, Ana M. F. Formação de Professores de Línguas em tempos críticos: desafios e possibilidades sustentados na amorosidade. Cap. 1. In: SILVA, Walkyri M.; SILVA, Wagner R.; CAMPOS, Diego M. (Orgs.) Desafios da Formação de Professores na Linguística Aplicada. Campinas, SP: Pontes Editores, 2019.

BARRETO, Beatriz C. B.; REIS, Bruno M.; MILLER, Inés K.; MONTEIRO, Maria Cristina G. G.; CUNHA, Maria Isabel A.; MOURA, Sabine M. L. Atividades com Potencial Exploratório: Caminhos para a coconstrução de entendimentos. In: ANDRADE, Mariana R. M. et al. (Orgs.) Professores de línguas em foco: ensino-aprendizagem de línguas, parceria universidade-escola, estágio. v. 3, p. 51-72. Brasília; Teresina: EDUFPI, 2019.

BASTOS, Liliana Cabral; BIAR, Liana de Andrade. Análise de narrativa e práticas de entendimento da vida social. DELTA, São Paulo, v. 31, n. spe, p. 97-126, Aug. 2015.

Disponível em

$<$ http://www.scielo.br/scielo.php?script=sci_arttext\&pid=S0102-

$44502015000300006 \&$ Ing $=e n \& n r m=$ iso $>$.

Acessado em julho 2019.

BEDRAN, Beatriz M. Ancestralidade e contemporaneidade das narrativas orais: A arte de cantar e contar histórias. Dissertação (Mestrado). Programa de Pós-Graduação em Ciência da Arte, Universidade Federal Fluminense, Rio de Janeiro, 2010.

BIAR, Liana de A. "Realmente as autoridade veio a me transformar nisso": narrativas de adesão ao tráfico e a construção discursiva do desvio. Tese (Doutorado) Departamento de Letras, Pontifícia Universidade Católica, Rio de Janeiro, 2012.

BOFF, Leonardo. Saber cuidar: ética do humano - compaixão pela terra. Rio de Janeiro: Vozes, 1999.

BOFF, Leonardo. Cuidar da Terra, proteger a vida: como evitar o fim do mundo. Rio de Janeiro: Record, 2010.

CAMERON, Lynne. Teaching Languages to Young Learners. Cambridge University Press, 2001.

CAPRA, Fritjof et al. Alfabetização Ecológica: educação das crianças para um mundo sustentável. SP: Editora Cultrix, 2006a.

CAPRA, Fritjof. A teia da vida: uma nova compreensão científica dos sistemas vivos. São Paulo: Cultrix, 2006b.

CELANI, Maria A. A. Afinal, o que é Linguística Aplicada? In: PASCHOAL, M. S. de \& CELANI, M. A. A. (orgs.) Linguística Aplicada: Da Aplicação 
da Linguística à Linguística Transdisciplinar. São Paulo: EDUC/PUC-SP, 1992. p. 15-23.

COSTA, Renato Pontes. Poder e negociação como relações pedagógicas. Memória da Pesquisa Confronto de Sistemas de Conhecimento na Educação Popular. Tese (Doutorado). Departamento de Educação, Pontifícia Universidade Católica, Rio de Janeiro, 2018.

COCHRAN-SMITH, Marilyn; LYTLE, Susan L. Inquiry as Stance: Practitioner Research for the Next Generation. New York: Teachers College Press, 2009.

CUNHA, Maria Isabel A. A Prática Exploratória na Clínica de Aprendizagem de Língua Inglesa. Apresentado no $14^{\circ}$ Congresso de Leitura do Brasil. Campinas: Unicamp, 2003. Disponível em http://2www.letras.pucrio.br/oldepcentre/eprecent/cole2003bebel.htm Acessado em julho 2019.

DENZIN, Norman K.; LINCOLN, Yvonna S. O Planejamento da Pesquisa Qualitativa: teorias e abordagens. Tradução Sandra Regina Netz. Porto Alegre: Artmet, 2006.

DERDYK, Edith. Formas de pensar o desenho: desenvolvimento do grafismo infantil. São Paulo: Scipione, 1989.

DERDYK, Edith. Linha de horizonte: por uma poética do ato criador. $12^{\circ}$ ed. Editora Intermeios, 2012.

EWALD, Clarissa X. "Eu não tô só participando. Tô usufruindo também." Prática Exploratória na formação do professor-pesquisador. Tese (Doutorado). Departamento de Letras, Pontifícia Universidade Católica, Rio de Janeiro, 2015.

Disponível em http://www.maxwell.vrac.puc-rio.br/25488/25488

Acessado em 2019.

FERREIRO, Emília. Reflexões sobre Alfabetização. São Paulo: Cortez, 1985.

FREIRE, Paulo. Pedagogia do Oprimido. $7^{\text {a }}$ ed. Rio de Janeiro: Paz e Terra, [1974]1979.

FREIRE, Paulo. Alfabetização como elemento de formação de cidadania. Ensinar, aprender: Leitura do mundo, leitura da palavra. Carta de Paulo freire aos professores. Estudos Avançados, v. 15, n. 42, 2001.

FREIRE, Paulo. Pedagogia da autonomia: saberes necessários à prática educativa. 57º ed. Rio de Janeiro/São Paulo: Paz e Terra, [1996]2018a. 
FREIRE, Paulo. Educação e mudança. $38^{\circ}$ ed. Rio de Janeiro/São Paulo: Paz e Terra, [1981]2018b.

FREIRE, Paulo. Pedagogia da tolerância. $6^{\circ}$ ed. Rio de Janeiro/São Paulo: Paz e Terra, [1995]2018c.

FULLAN, Michael; HARGREAVES, Andy. Por que é que vale a pena lutar? O trabalho de equipa na escola. Porto: Porto, 2001.

FUZER, Cristiane; CABRAL, Sara. Introdução à Gramática SistêmicoFuncional em Língua Portuguesa. São Paulo: Mercado das Letras, 2014.

GARCÍA, Ofelia. Bilingual Education in the $21^{\text {st }}$ Century: A Global Perspective. UK: Wiley-Blackwell, 2009.

GARCÍA, Ofelia. Translanguaging and learning. Université du Luxembourg, 2017.

Disponível em https://www.youtube.com/watch?v=fjBPxUm0hAM Acessado em julho de 2019.

GIEVE, Simon; MILLER, Inés K. What do you mean by Quality of Classroom Life? In: GIEVE, S.; MILLER, I. (eds.). Understanding the Language Classroom. 1st ed. Basingtoke: Palgrave Macmillan, 2006. p. 18-42.

GLEISER, Marcelo. A simples beleza do inesperado: um filosofo natural em busca de trutas e do sentido da vida. RJ: Record, 2016.

HALLIDAY, Michael A. K. An Introduction to Functional Grammar. $2^{\text {nd }}$ ed. London: Arnold, 1994.

HALLIDAY, Michael A. K.; HASAN, Ruqaiya. Language, context and text: Aspects of language in a social-semiotic perspective. $2^{\text {nd }}$ ed. Oxford: Oxford University Press, 1989.

HALLIDAY, Michael A. K.; MATHIESSEN, Christian. An Introduction to Functional Grammar. $4^{\text {rd }}$ ed. London, New York: Arnold, 2014.

HANKS, Judith. Exploratory Practice in Language Teaching. UK: Palgrave/Macmillan, 2017.

HARGREAVES, Andy. Os professores em tempos e mudança: o trabalho e a cultura dos professores na idade Pós-Moderna. Portugal: McGraw-Hill, 1998.

hooks, bell. Ensinando a transgredir: a educação como prática da liberdade. São Paulo: Martins Fontes, 2013. 
ISODA, Gil Tokio de Tani. Sobre desenho: estudo teórico-visual. Dissertação de Mestrado USP, SP, 2013.

Disponível em http://www.teses.usp.br/teses/disponiveis/16/16134/tde12082013-100125/pt-br.php

Acessado em maio de 2019.

JORDÃO, Clarissa M. (Org.) A Linguística no Brasil: rumos e passagens. Campinas, SP: Pontes Editores, 2016.

KRAMER, Sonia. Autoria e Autorização: questões éticas na pesquisa com crianças. Caderno de Pesquisa, n. 116, p. 41-59, julho, 2002.

Disponível em http://www.scielo.br/pdf/\%0D/cp/n116/14398.pdf

Acessado em abril de 2019.

LOUV, Richard. The Last Child in the Woods: saving our children from nature-deficit disorder. New York: Workman Publishing Company, 2005.

MAHER, Terezinha J. M. Políticas Linguísticas E Políticas De

Identidade: currículo e representações de professores indígenas na

Amazônia ocidental brasileira. Currículo sem Fronteiras, v.10, n.1, p. 33-

48, Jan/Jun, 2010. Disponível em

http://www.curriculosemfronteiras.org/vol10iss1articles/maher.pdf

Acessado em julho 2018.

MARTIN, Jim R. Beyond Exchange: appraisal systems in English. In: HUSTON, Susan; THOMPSON, Geoff (Eds.). Evaluation in text: Authorial Stance and the Construction od Discourse. Oxford: Oxford University Press, 2003.

MARTIN, Jim R.; ROSE, David. Working with discourse: Meaning beyond the clause. p. 16-71. London: Continuum, 2003.

MARTIN, Jim R.; WHITE, Peter R. R. The language of evaluation: appraisal in English. New York: Palgrave Macmillan, 2005.

MATURANA, Humberto. Emoções e Linguagem na Educação e na Política. $3^{\mathrm{a}}$ ed. Belo Horizonte: Editora UFMG, 2002.

MILLER, Inés K.; BARRETO, Beatriz. C.; NÓBREGA-KUSCHNIR, Adriana N. A.; SETTE, M. L.; BEZERRA, Isabel. C.; CUNHA, Maria I. A.; BRAGA, Walewska G. Prática Exploratória: questões e desafios. In GIL, G.; ABRAHÃO, M. H. (Org.). Educação de professores de línguas: os desafios do formador, p. 145-165. Campinas, SP: Editora Pontes, 2008.

MILLER, Inés K.; CUNHA, Maria I. A.; Members of the Rio de Janeiro EP group. The 'web of life' of the Rio de Janeiro Exploratory Practice group. In: ALLWRIGHT, D.; HANKS, J. The developing language learner: an introduction toExploratory Practice. Hampshire, UK: Palgrave Macmillan. 2009. 
MILLER, Inés K. Construindo parcerias Universidade-escola: caminhos éticos e questões crítico-reflexivas. In: GIMENEZ, Telma; MONTEIRO, Maria Cristina de Góes. Formação de professores de línguas na América Latina e transformação social. Coleção: Novas Perspectivas em Linguística Aplicada. Vol. 4, p. 109-129. Campinas, SP: Pontes Editores, 2010.

MILLER, Inés K. A Prática Exploratória na educação continuada de professores de línguas: inserções acadêmicas e teorizações híbridas. In: SILVA, K. A.; DANIEL, F. G.; KANEKO-MARQUES, S. M.; SALOMÃO, A. C. B. (Orgs). A formação de professores de línguas: novos olhares. Vol. II. p. 319-341. São Paulo: Pontes Editores, 2012.

MILLER, Inés K. Formação Inicial e Continuada de Professores de Línguas: da Eficiencia à Reflexão Crítica e Ética. In: MOITA LOPES, L. P. Linguística Aplicada na Modernidade Recente: festschrift para Antonieta Celani, p. 99-121. São Paulo: Parábola Editorial, 2013.

MILLER, Inés K.; CUNHA, Maria I. A. Exploratory Practice in Continuing Professional Development: Critical and Ethical Issues. In: DIKILITAS, K. (Ed.). Facilitating In-Service Teacher Training for Professional Development. p. 61-85. Pennsylvania: IGI Global, 2017.

MILLER, Inés K. Prática Exploratória no Subprojeto Letras-Inglês do PIBID/PUC-Rio. In: SALOMÃO, Maria R. P. Et al. (orgs.). Experiências na Formação dos Professores: cinco anos de PIBID/PUC-Rio. Rio de Janeiro: ED. PUC-Rio, 2017.

MILLER, Inés K.; CUNHA, Maria Isabel; MORAES BEZERRA, Maria Isabel; NÓBREGA, Adriana N.; EWALD, Clarissa; BRAGA, Walewska G. Teaching English to Young Learners: Some Reflective Voices from Latin America. In: GARTON, Sue; COPLAND, Fiona, The Routledge Handbook of Teaching English to Young Learners, pp. 508-522. Abingdon: Routledge, 2019.

MILLER, Inés K.; CUNHA, Maria I. A. Exploratory Practice: Integrating research into regular pedagogic activities. In: The Routledge Handbook of English Language Teacher Education. Eds. Steve Walsh; Steve Mann. Routledge. 1st ed. pp. 583-595. New York, USA, 2019.

MOITA, Maria da C. Percursos de formação e de transformação. In: NÓVOA, António, et al. Vida de Professores. Porto: Porto Editora, 2015.

MOITA LOPES, Luiz P. Oficina de Linguística Aplicada: A natureza social e educacional dos processos de ensino/aprendizagem de línguas. Campinas, SP: Mercado de Letras, 1996.

MOITA LOPES, Luiz P. Contemporaneidade e construção de conhecimento na área de Estudos Linguísticos. In: DUARTE, Lélia P. 
(Org.) Revista do Programa de Pós-graduação em Letras e do Cespuc. Scripta, v. 17, n. 14. p. 159-171. Belo Horizonte: PUC Minas, 2004.

MOITA LOPES, Luiz P. (Org.) Por uma Linguística Indisciplinar. São Paulo: Parábola Editorial, 2006.

MOITA LOPES, Luiz P. (Org.) Linguística Aplicada na Modernidade Recente: festschrift para Antonieta Celani. São Paulo: Parábola Editorial, 2013.

MORAES BEZERRA, Isabel $C$. R. Com quantos fios se tece uma reflexão? Narrativas e argumentações no tear da interação. Tese (Doutorado). Departamento de Letras, Pontifícia Universidade Católica, Rio de Janeiro, 2007.

Disponível em https://www.maxwell.vrac.pucrio.br/colecao.php?strSecao=resultado\&nrSeq=10477@1

Acessado em junho 2019.

NÓBREGA, Adriana N. A. K. O afeto e a socioconstrução do conhecimento na sala de aula de língua estrangeira. Pesquisas em Discurso Pedagógico, Rio de Janeiro, PUC-Rio, v. 2, n. 1, p. 47-60, 2003.

NÓBREGA, Adriana N. A. Narrativas e avaliação no processo de construção do conhecimento pedagógico: abordagem sociocultural e sociossemiótica. Tese (Doutorado). Departamento de Letras, Pontifícia Universidade Católica, Rio de Janeiro, 2009.

Disponível em https://www.maxwell.vrac.puc-rio.br/

Acessado em junho 2019.

NÓBREGA, Adriana N. A.; ABREU, Adriana R. Avaliação, identidades e gênero social: análise de narrativas de mulheres em encontro social acadêmico. (no prelo)

NÓVOA, António. Formação de professores e profissão docente. In: NÓVOA, António. Os professores e sua formação. p.139-158. Lisboa: Instituto de Inovação Educacional, 1992.

NÓVOA, António. Professor se forma na escola. Revista Nova Escola. Maio, 2001.

Disponível em https://novaescola.org.br/conteudo/179/entrevista-

formacao-antonio-novoa

Acessado em maio 2019.

NÓVOA, António. Para uma formação de professor construída dentro da profissão. Universidade de Lisboa, Portugal, 2009. Disponível em http://www.revistaeducacion.educacion.es/re350/re350 09por.pdf

Acessado em maio 2019. 
NÓVOA, António. Os professores e as histórias da sua vida. In: NÓVOA, António (Org). Vidas de professores. $2^{\mathrm{a}}$ ed. pp. 11-30. Porto: Porto Editora, 2013.

ORR, David W. Lugar e Pedagogia. In: CAPRA, Fritjof et al. Alfabetização Ecológica: educação das crianças para um mundo sustentável. p. 114-124. São Paulo: Editora Cultrix, $2006 a$.

ORR, David W. Reminiscências. In: CAPRA, Fritjof et al. Alfabetização Ecológica: educação das crianças para um mundo sustentável. p. 125136. São Paulo: Editora Cultrix, 2006b.

PALMER, Parker J. A Coragem de Ensinar: explorando a paisagem interior da vida de um professor. São Paulo: Editora Da Boa Prosa, 2012.

PEREIRA, Gisela F. S. Desenho de Moda: onde tudo começa... In: TRINCHÃO, Gláucua M. C. (Org.) Desenho, Moda e Cultura. UEFS, Salvador, 2015.

PIEDADE, Renan S. Construções identitárias no contexto de formação de línguas. Dissertação (Mestrado). Departamento de Letras, Pontifícia Universidade Católica, Rio de Janeiro, 2019.

PILLAR, Analice D. 0 desenho e escrita como sistemas de representação. Porto Alegre: Artes Médicas, 1996.

PINTER, Annamaria; ZANDIAN, Samaneh. 'I don't ever want to leave this room': benefits of researching 'with' children. ELT Journal, Volume 68 (Number 1), p. 64-74, 2014.

PINTER, Annamaria. Teaching Young Language Learners. $2^{\text {nd }}$ ed. Oxford University Press, 2017.

PRABHU, N. S. The dynamics of the language lesson. Tesol Quarterly, v. 26, n. 2, p. 225-241, 1992.

REIS, Bruno de M. O lugar-escola em discurso: etnografia, identidade e epistemologia na pesquisa qualitativa. Tese (Doutorado). Departamento de Letras, Pontifícia Universidade Católica, Rio de Janeiro, 2018.

Disponível em

https://www.maxwell.vrac.puc-

rio.br/Busca etds.php?strSecao=resultado\&nrSeq=34773@2

Acessado em maio 2019.

RIO DE JANEIRO (Estado), Conselho Estadual de Educação do Governo do Rio de Janeiro, Resolução CEE № 341, de 12 de novembro de 2013. Disponível em http://www.cee.ri.gov.br/deliberacoes/D 2013-341.pdf Acessado em julho de 2019. 
ROBINSON, Heljä A. The Ethnography of Empowerment: the transformative power of classroom interaction. USA: The Falmer Press, 1994.

ROJO, Roxane H. R. Letramentos múltiplos, escola e inclusão social. São Paulo: Parábola Editorial, 2009.

ROJO, Roxane H. R.; BARBOSA, Jacqueline P. Hipermodernidade, multiletramentos e gêneros discursivos. São Paulo: Parábola Editorial, 2015.

SARAMAGO, Jose. De como a personagem foi mestre e o autor seu aprendiz. Discurso pronunciado a 7 de Dezembro de 1998 na Academia Sueca.

Disponível em https://www.josesaramago.org/wpcontent/uploads/2014/12/discursos estocolmo portugues.pdf Acessado em maio 2019.

SHAPIRO, Shauna. The Art \& Science of Mindfulness. Awakening to Mindfulness. Apresentado por FACES Conferences. Seattle. Oct. 2009. Disponível em https://www.youtube.com/watch?v=H9vOBd39u2w (Part 1) https://www.youtube.com/watch?v=Vk7Fd7mew10 (Part 2)

Acessado em abril de 2019.

SOARES, Magda. Letramento: um tema em três gêneros. $2^{\mathrm{a}}$ ed. Belo Horizonte: Editora Autêntica, 2004.

SOUZA, Emanuelle S. F. "Professora, você podia dar aula de sociologia": entendendo a sala de alua de língua inglesa através das lentes dos alunos. Dissertação (Mestrado) Universidade do Estado do Rio de Janeiro, Faculdade de Formação de Professores, Rio de Janeiro, 2018.

TARDIF, Maurice. Saberes Profissionais dos Professores e Conhecimentos Universitários: elementos para uma epistemologia da prática profissional dos professores e suas consequências em relação à formação para o magistério. Revista Brasileira de Educação. ANPED, São Paulo, n. 13, p. 5-24, Jan/Fev/Mar/Abr, 2000.

Disponível em:

http://www.anped.org.br/sites/default/files/rbe/files/rbe 13.pdf

Acessado em: dezembro 2019.

THOMPSON, Geoff. Introducing Functional Grammar. $3^{\text {rd }}$ ed. London and New York: Routledge, 2014.

TUAN, Yi-Fu. Espaço e lugar: a perspectiva da experiência. Trad. Lívia de Oliveira. Londrina: Eduel, 2013.

VELHO, Gilberto. Observando o familiar. In: NUNES, E. A aventura sociológica. Rio de Janeiro: Zahar, 1978. 
VELHO, Gilberto. Antropologia Urbana: interdisciplinaridade e fronteiras do conhecimentos. MANA 17(1): 161-185, 2011.

Disponível em http://www.scielo.br/pdf/mana/v17n1/v17n1a07.pdf

Acessado em junho de 2019.

VIAN JR., Orlando. O sistema de avaliatividade e os recursos para gradação em Língua Portuguesa: questões terminológicas e de instanciação. DELTA, volume 25, no. 1, p. 99-129, 2009.

VIAN JR., Orlando. O sistema de avaliatividade e a linguagem da avaliação. In: VIAN JR., O; SOUZA, A. A. de; ALMEIDA, F. S. D. P. (Orgs.). A linguagem de avaliação em língua portuguesa. Estudos sistêmico-funcionais com base no sistema de avaliatividade. São Carlos: Pedro e João Editores, 2010.

VIAN JR., Orlando. Linguística Sistêmico-Funcional, Linguística Aplicada e Linguística Educacional. In: MOITA LOPES, L. P. Linguística Aplicada na Modernidade Recente: festschrift para Antonieta Celani, p. 123-141. São Paulo: Parábola Editorial, 2013.

WHITE, Peter. Valoração: a linguagem da avaliação e da perspectiva. Linguagem em (Dis)curso - LemD, Tubarão, v. 4, p. 178-205, n. esp, 2004. 


\title{
Anexo 1
}

\section{Pontifícia Universidade Católica DO RIO DE JANEIRO}

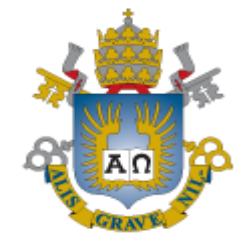

\section{CARTA DE ANUÊNCIA PARA AUTORIZAÇÃO DE PESQUISA}

\author{
Às Diretoras da XXXXXXXX
}

Solicitamos autorização institucional para realização da pesquisa sob o título Escolarização bilíngue de crianças: um estudo de caso na perspectiva da Linguística Aplicada (título provisório) a ser realizada pela aluna Mara Regina de Almeida Griffo, sob orientação da Profa. Dra. Inés Kayon de Miller, no Programa de Pós-Graduação Estudos da Linguagem (PPGEL), do Departamento de Letras da Pontifícia Universidade Católica do Rio de Janeiro.

Nesta pesquisa, pretendemos entender questões relacionadas ao ensino e a aprendizagem de inglês no contexto escolar. Os dados serão gerados em uma turma de crianças entre 9 e 11 anos de idade, matriculadas no Programa Bilíngue da escola. As contribuições do alunos para a pesquisa serão feitas através de textos escritos, desenhos, pôsteres e gravações em áudio produzidos durante o horário escolar. Não incluiremos filmagens nem fotografias dos alunos. As atividades produzidas pelos alunos serão usadas em reflexões e conversas entre a pesquisadora e a professora-colaboradora, em encontros gravados em áudio, transcritos e analisados discursivamente, com o consentimento da mesma.

Os nomes dos alunos serão removidos dos textos escritos, desenhos e pôsteres e serão substituídos por nomes fictícios para preservar suas identidades. A pesquisa envolve riscos mínimos, como um eventual reconhecimento do texto escrito ou do desenho do(a) aluno(a). A pesquisadora irá tratar a identidade do(a) menor com padrões profissionais de sigilo, atendendo a legislação brasileira (Resolução No 466/12 do Conselho Nacional de Saúde), utilizando as informações somente para os fins acadêmicos e científicos. Ressaltamos que o nome da instituição será omitido na pesquisa. Contudo, a referência ao Programa Bilíngue de uma escola da rede particular no Estado do Rio de Janeiro pode apresentar o risco de reconhecimento da instituição.

Estaremos à disposição para qualquer esclarecimento durante a pesquisa. Os resultados estarão a sua disposição quando finalizada a mesma.

Esta carta de anuência encontra-se redigida e impressa em duas vias originais, sendo que, depois de assinadas, uma será arquivada pela pesquisadora responsável e a outra será fornecida à escola. 
Declaramos ter lido a carta de anuência e concordamos que a pesquisa seja realizada na XXXXXXXX, em horário escolar com um grupo de alunos matriculados no Programa Bilíngue. Esta instituição está ciente de suas responsabilidades, dos possíveis riscos de desconforto ou constrangimento com a divulgação dos dados, e do eventual reconhecimento da escola no texto da pesquisa.

Rio de Janeiro, de de 2019.

XXXXXXXXXX
Diretora administrativa
E-mail:
Telefone:

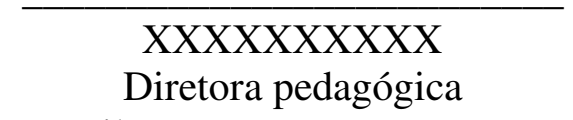

E-mail:

Diretora pedagógica

Telefone:

Mara Regina de Almeida Griffo
Pesquisadora
E-mail: marargriffo@gmail.com Telefone: (21)

\author{
Profa. Dra. Inés Kayon de Miller \\ Orientadora \\ E-mail: inesmiller@hotmail.com \\ Telefone: (21) 99887-9222
}

\section{Pontifícia Universidade Católica do Rio de Janeiro - Departamento de Letras Endereço: Rua Marquês de São Vicente, 225 - Gávea - Rio de Janeiro - RJ CEP: 22451-900 - Telefone: (21) 3527-1444}

Comitê de Ética em Pesquisa da Pontifícia Universidade Católica do Rio de Janeiro Endereço: Rua Marquês de São Vicente, 225 - Gávea - Rio de Janeiro - RJ CEP: 22451-900

Prédio Kennedy - $2^{\circ}$ andar Telefone: 552135271134 E-mail: vrac@puc-rio.br 


\section{Anexo 2}

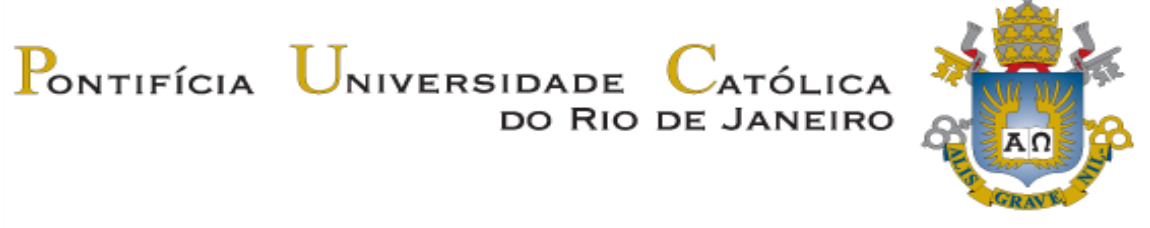

TERMO DE CONSENTIMENTO LIVRE E ESCLARECIDO

$\mathrm{O}$ (A) menor —u, sob sua responsabilidade, está sendo convidado(a) como voluntário(a) a participar da pesquisa Escolarização bilíngue de crianças: um estudo de caso na perspectiva da Linguística Aplicada (título provisório). Nesta pesquisa, pretendemos entender questões relacionadas ao ensino e a aprendizagem de inglês no contexto escolar. Utilizaremos dados gerados em atividades realizadas em sala de aula. As contribuições na pesquisa serão feitas através de textos escritos, desenhos, pôsteres e gravações em áudio produzidos pelos alunos durante o horário escolar. Não incluiremos filmagens nem fotografias dos alunos. As atividades dos alunos serão usadas em reflexões e conversas entre a pesquisadora e a professoracolaboradora. Esses encontros serão gravados em áudio, transcritos e analisados discursivamente, com o consentimento da mesma.

Para participar desta pesquisa, o(a) menor sob sua responsabilidade não terá nenhum custo, nem receberá qualquer vantagem financeira. Apesar disso, caso sejam identificados e comprovados danos provenientes desta pesquisa, ele tem assegurado o direito à indenização. Ele(a) será esclarecido(a) em qualquer aspecto que desejar e estará livre para participar ou recusar-se a participar. O(A) Sr.(a), como responsável pelo(a) menor, poderá retirar seu consentimento ou interromper a participação dele(a) a qualquer momento. A participação dele(a) é voluntária e a recusa em participar não acarretará qualquer penalidade ou modificação na forma em que é atendido(a). A pesquisadora irá tratar a identidade do(a) menor com padrões profissionais de sigilo, atendendo a legislação brasileira (Resolução N $^{\circ}$ 466/12 do Conselho Nacional de Saúde), utilizando as informações somente para os fins acadêmicos e científicos. $\mathrm{O}(\mathrm{A})$ menor não será identificado(a) em nenhuma publicação. Seu nome será removido dos textos escritos, desenhos e pôsteres e será substituído por nomes fictícios. Esta pesquisa envolve riscos mínimos, como um eventual reconhecimento do texto escrito ou do desenho do(a) aluno(a) assim como a possibilidade de desconforto ou constrangimento com a divulgação dos dados.

A pesquisa contribuirá para a reflexão e o entendimento de questões advindas do ambiente da sala de aula no Programa Bilíngue de uma escola da rede particular no Estado do Rio de Janeiro. Os resultados estarão a sua disposição quando finalizada a pesquisa. O nome ou o material que indique a participação do menor não será liberado sem a sua permissão. Os dados e instrumentos utilizados na pesquisa ficarão arquivados com o pesquisador responsável, por um período de 5 (cinco) anos, e após esse tempo serão destruídos.

Este termo de consentimento encontra-se redigido e impresso em duas vias originais, que depois de assinadas, uma será arquivada pela pesquisadora responsável, no Programa de Pós-Graduação Estudos da Linguagem, da PUC-Rio e a outra será fornecida ao Sr.(a).

$\mathrm{Eu}$, portador(a) do documento de Identidade responsável pelo(a) menor

presente estudo de maneira clara e detalhada e esclareci minhas dúvidas. 
Sei que a qualquer momento poderei solicitar novas informações e modificar a decisão do(a) menor sob minha responsabilidade de participar, se assim o desejar. Recebi uma via original deste termo de consentimento livre e esclarecido e me foi dada a oportunidade de ler e esclarecer as minhas dúvidas.

Rio de Janeiro, de de 2019.

Email:

$\overline{\text { Mara Regina de Almeida Griffo }}$ Pesquisadora

E-mail:

marargriffo@gmail.com

Telefone: (21) 98131-7261

Telefone:

\author{
Profa. Inés Kayon de Miller \\ Orientadora \\ E-mail: \\ inesmiller@hotmail.com \\ Telefone: (21) 99887-9222
}

Pontifícia Universidade Católica do Rio de Janeiro - Departamento de Letras

Endereço: Rua Marquês de São Vicente, 225 - Gávea - Rio de Janeiro - RJ

CEP: 22451-900 - Telefone: (21) 3527-1444

Comitê de Ética em Pesquisa da Pontifícia Universidade Católica do Rio de Janeiro

Endereço: Rua Marquês de São Vicente, 225 - Gávea - Rio de Janeiro - RJ

CEP: 22451-900

Prédio Kennedy - $2^{\circ}$ andar Telefone: 552135271134 E-mail: vrac@puc-rio.br 


\section{Anexo 3}

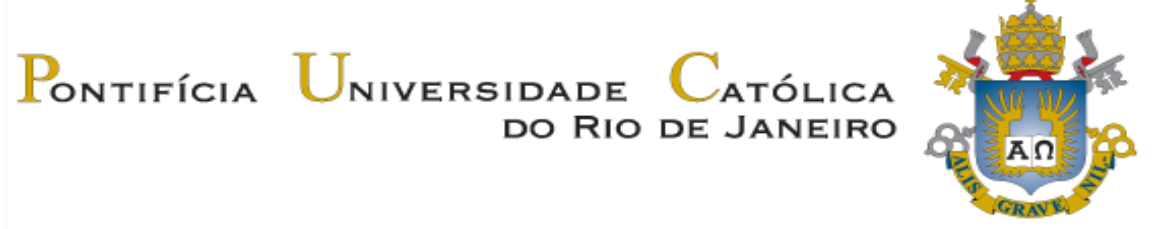

\section{TERMO DE ASSENTIMENTO LIVRE E ESCLARECIDO}

Você está sendo convidado(a) como voluntário(a) a participar da pesquisa Escolarização bilíngue de crianças: um estudo de caso na perspectiva da Linguística Aplicada (título provisório), que está sendo feita no Departamento de Letras da PUC-Rio. Nesta pesquisa, vamos trabalhar com questões relacionadas ao ensino e a aprendizagem de inglês na escola. Vamos precisar de algumas atividades feitas por você, em sala de aula, no horário do Programa Bilíngue, como textos escritos, desenhos, pôsteres e gravações em áudio. Não vamos incluir filmagens nem fotografias suas.

Agradecemos sua colaboração e explicamos abaixo sua participação na pesquisa.

- Você vai ser informado(a) sobre as etapas da pesquisa;

- Você pode desistir a qualquer momento de participar da pesquisa, sem nenhum problema;

- Você vai ter sua privacidade respeitada, ou seja, seu nome vai ser trocado para ninguém saber sobre suas informações pessoais;

- Seus responsáveis serão informados sobre a pesquisa e você somente vai participar com a autorização deles.

Este documento foi escrito e impresso em duas vias originais. Depois que você assinar, uma cópia será arquivada pela pesquisadora responsável, no Programa de PósGraduação Estudos da Linguagem, da PUC-Rio e a outra cópia será entregue a você.

$\mathrm{Eu}$, fui informado sobre a pesquisa e sei que a qualquer momento poderei pedir novas informações. Entendo que meu responsável poderá modificar minha decisão de participar da pesquisa. Tendo o consentimento do meu responsável já assinado, declaro que concordo em participar da pesquisa e que tive a oportunidade de ler, perguntar e esclarecer as minhas dúvidas. 
Rio de Janeiro, de de 2019.

\section{Aluno(a)}

\author{
Mara Regina de Almeida Griffo \\ Pesquisadora \\ E-mail: \\ marargriffo@gmail.com \\ Telefone: (21) 98131-7261
}

\author{
Profa. Inés Kayon de Miller \\ Orientadora \\ E-mail: \\ inesmiller@hotmail.com \\ Telefone: (21) 99887-9222
}

Pontifícia Universidade Católica do Rio de Janeiro - Departamento de Letras

Endereço: Rua Marquês de São Vicente, 225 - Gávea - Rio de Janeiro - RJ

CEP: 22451-900 - Telefone: (21) 3527-1444

Comitê de Ética em Pesquisa da Pontifícia Universidade Católica do Rio de Janeiro Endereço: Rua Marquês de São Vicente, 225 - Gávea - Rio de Janeiro - RJ CEP: 22451-900

Prédio Kennedy - $2^{\circ}$ andar Telefone: 552135271134 E-mail: vrac@puc-rio.br 